Christian Missions and Humanitarianism in the Middle East, 1850-1950 


\section{Leiden Studies in Islam and Society}

Editors

Léon Buskens (Leiden University)

Nathal M. Dessing (Leiden University)

Petra M. Sijpesteijn (Leiden University)

Editorial Board

Maurits Berger (Leiden University) - R. Michael Feener

(Oxford University) - Nico Kaptein (Leiden University)

Jan Michiel Otto (Leiden University) - David S. Powers (Cornell University)

VOLUME 11

The titles published in this series are listed at brill.com/lsis 


\title{
Christian Missions and Humanitarianism in the Middle East, $185^{\circ}-195^{\circ}$
}

Ideologies, Rhetoric, and Practices

\author{
Edited by \\ Inger Marie Okkenhaug \\ Karène Sanchez Summerer
}

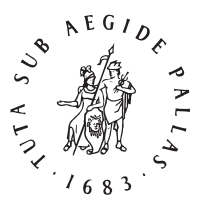

B R I L L 
This is an open access title distributed under the terms of the CC BY-NC 4.o license, which permits any non-commercial use, distribution, and reproduction in any medium, provided the original author(s) and source are credited. Further information and the complete license text can be found at https://creativecommons.org/licenses/by-nc/4.o/

The terms of the cc license apply only to the original material. The use of material from other sources (indicated by a reference) such as diagrams, illustrations, photos and text samples may require further permission from the respective copyright holder.

Cover illustration: "Les Capucins français en Syrie. Secours aux indigents". Postcard, Collection Gélébart (private collection), interwar period.

\section{Library of Congress Cataloging-in-Publication Data}

Names: Okkenhaug, Inger Marie, editor. | Sanchez Summerer, Karène, editor.

Title: Christian missions and humanitarianism in the Middle East, 1850-1950 : ideologies, rhetoric, and practices / edited by Inger Marie Okkenhaug, Karène Sanchez Summerer.

Other titles: Leiden studies in Islam and society ; v. 11.

Description: Leiden ; Boston : Brill, 202O. | Series: Leiden studies in Islam and society, 2210-8920; 11 Includes bibliographical references and index.

Identifiers: LCCN 2020018566 (print) | LCCN 2020018567 (ebook) | ISBN 9789004394667 (hardback) | ISBN 978900443453 (ebook)

Subjects: LCSH: Missions-Middle East-History-19th century. | Missions-Middle East-History-2oth century. | Humanitarian assistance-Middle East-History19th century. | Humanitarian assistance-Middle East-History-2oth century.

Classification: LCC BV316o .C46 2020 (print) | LCC BV316o (ebook) | DDC 266.0o956-dc23

LC record available at https://lccn.loc.gov/2020018566

LC ebook record available at https://lccn.loc.gov/2020018567

Typeface for the Latin, Greek, and Cyrillic scripts: “Brill”. See and download: brill.com/brill-typeface.

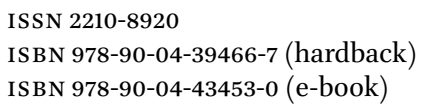

Copyright 2020 by the Editors and Authors.

This book is printed on acid-free paper and produced in a sustainable manner.

Copyright 2020 by the Editors and Authors. Published by Koninklijke Brill NV, Leiden, The Netherlands. Koninklijke Brill NV incorporates the imprints Brill, Brill Hes \& De Graaf, Brill Nijhoff, Brill Rodopi, Brill Sense, Hotei Publishing, mentis Verlag, Verlag Ferdinand Schöningh and Wilhelm Fink Verlag. Koninklijke Brill NV reserves the right to protect this publication against unauthorized use.

This book is printed on acid-free paper and produced in a sustainable manner. 


\section{Contents}

Acknowledgements VII

List of Figures VIII

Notes on Contributors $\mathrm{X}$

Introduction 1

Inger Marie Okkenhaug and Karène Sanchez Summerer

\section{PART 1}

\section{Prologue}

1 Missions, Charity, and Humanitarian Action in the Levant (19th-2oth Century) 21

Chantal Verdeil

\section{PART 2}

\section{Advocacy}

$2 \quad$ Liberated Bodies and Saved Souls: Freed African Slave Girls and Missionaries in Egypt 41

Beth Baron

3 Physical Expressions of Winning Hearts and Minds: Body Politics of the American Missionaries in "Asiatic Turkey" 62

Nazan Maksudyan

4 Spiritual Reformation and Engagement with the World: Scandinavian Mission, Humanitarianism, and Armenians in the Ottoman Empire, 1905-1914 9o

Inger Marie Okkenhaug

5 "A Strange Survival": The Rev. W.A. Wigram on the Assyrians before and after World War I 110

Heleen Murre-van den Berg 


\section{PART 3}

Best Practices

6 Missionary Hubris in Colonial Algeria? Founding and Governing Christian Arab Villages 1868-1930 133 Bertrand Taithe

7 Missionary Work, Secularization, and Donor Dependency: RockefellerNear East Colleges Cooperation after World War I (1920-1939) 155

Philippe Bourmaud

8 "Machine Age Humanitarianism": American Humanitarianism in Early 2oth-Century Syria and Lebanon 183 Idir Ouahes

9 Scottish Presbyterian Churches and Humanitarianism in the Interwar Middle East 209 Michael Marten

\section{PART 4 \\ Epilogue: Impact of the 1948 Crisis}

10 Confined by Conflict, Run by Relief: Arabs, Jews, and the Finnish Mission in Jerusalem, 1940-1950 233

Seija Jalagin

11 Catholic Humanitarian Assistance for Palestinian Refugees: The Franciscan Casa Nova of Jerusalem during the 1948 War 253 Maria Chiara Rioli

Index $\quad 277$ 


\section{Acknowledgements}

This volume is the result of a NWo (the Dutch Research Council) Internationalisation in the Humanities research project "Engaging Europe in the Arab World: European missionaries and humanitarianism in the Middle East (1850-1970)", in cooperation with the IE G Leibniz Institute of European History (Mainz, Germany) and the IISM M, Institut d'études de l'Islam et des Sociétés du monde musulman (Paris, France).

We would like to thank the Dutch Research Council for financing this research project, as well as the IEG Leibniz Institute of European History, the IISM m Institut d'études de l'Islam et des Sociétés du monde musulman and the Institut Universitaire de France for their financial and administrative support of the international workshops where some of the papers for this book were first presented and discussed. We would also like to thank Volda University College for their contribution to funding this publication.

We are grateful to many colleagues in Leiden, Mainz, Paris, and elsewhere who, through their contributions to conferences, workshops and through extended email conversations over the years, helped us to flesh out our questions, concerns, and approaches. 


\section{Figures}

1.1 Postcard, Collection Gélébart, private collection. 33

3.1 Aram (before photograph). Reproduced from "For Young People: Orphans in Turkey," Missionary Herald vol. 94 (May 1898): 204-208 70

3.2 Boys coming to Home (before photograph). Reproduced from "For Young People: Orphans in Turkey," Missionary Herald vol. 94 (May 1898): 204-208 70

3.3 Orphans at Oorfa at dinner (after photograph). Reproduced from "For Young People: Orphans in Turkey," Missionary Herald vol. 94 (May 1898): 204-208 71

3.4 A rescued orphan girl (after photograph). Reproduced from "For Young People: Orphans in Turkey," Missionary Herald vol. 94 (May 1898): 204-208 72

3.5 Village Armenians (before photograph). Reproduced from Rev. George C. Reynolds, "For Young People: A Gospel Triumph in the Land of Ararat," Missionary Herald vol. 91 (May 1896): 212-216 75

3.6 The family at Van (after photograph). Reproduced from Rev. George C. Reynolds, "For Young People: A Gospel Triumph in the Land of Ararat," Missionary Herald vol. 91 (May 1895): 212-216 76

3.7 An Armenian family. Reproduced from J.E. Pierce, of Bardezag, "For Young People: Who are the Armenians," Missionary Herald vol. 87 (April 1891): $175^{-178} 77$

3.8 A group of Alumni, Bithynia High School, Bardizag. SALt Archives, American Board of Commissioners for Foreign Missions / Photographs / Bardizag, ABAHBARDoO9 78

3.9 A Greek peasant woman. Reproduced from Rev. James W. Selye, of Constantinople, "For Young People: A Greek Town in Turkey," Missionary Herald vol. 85 (October 1889): 424-427 79

4.1 Girls in the orphanage in Musch with dolls from Scandinavian donors. Note: "Barn ved Musch barnehjem?" Wikimedia, made available by National Archives of Norway, https://commons.wikimedia.org/wiki/File:Barn_ved_Musch _barnehjem\%3F_-_fo3014171218005o.jpg 105

4.2 Armenian women. Note: "Armenske kvinner," Wikimedia, made available by National Archives of Norway, https://commons.wikimedia.org/wiki/ File:Armenske_kvinner_-_fo30141712190o13_1469.jpg 106

4.3 Bodil Biørn and teacher Maritza with 1st grade in Mush, ca. 1912. Note: "Bodil Biørn med skoleklasse," Wikimedia, made available by National Archives of Norway, https://commons.wikimedia.org/wiki/File:Bodil_Bi\%C3\%B8rn_med _skoleklasse_-_fo30141712180005.jpg 107

8.1 A 1917 ACRNE poster depicting the compassionate, if Orientalist, efforts of American humanitarianism in the Middle East. Library of Congress collection, retrieved from https://lccn.loc.gov/2002711981 192 
8.2 Another 1917 ACRNE poster asking for compassionate donations from American citizens. Library of Congress collection, retrieved from https://lccn.loc.gov/2002719422 193

8.3 A later poster dating from 1919 and printed by ACRNE's successor organization; Near East Relief (NER). Library of Congress collection, retrieved from https://lccn.loc.gov/2002708879 196

11.1 Jerusalem casa nova, early 2oth century, AScTs 270 


\section{Notes on Contributors}

\section{Beth Baron}

is Distinguished Professor of History at the City College and Graduate Center of the City University of New York and Director of the Middle East and Middle Eastern American Center at the CUNY Graduate Center. From 2009 to 2014, she edited the International Journal of Middle East Studies, and from 2015 to 2017, served as president of the Middle East Studies Association of North America. Her most recent book, The Orphan Scandal: Christian Missionaries and the Rise of the Muslim Brotherhood, appeared with Stanford University Press in 2014. Earlier works include Egypt as a Woman: Nationalism, Gender, and Politics (Berkeley: University of California Press, 2005) and The Women's Awakening in Egypt: Culture, Society, and the Press (New Haven: Yale University Press, 1994). She co-edited Women in Middle Eastern History: Shifting Boundaries in Sex and Gender (New Haven: Yale University Press, 1991) with Nikki Keddie and Iran and Beyond: Essays in Middle Eastern History in Honor of Nikki R. Keddie (Costa Mesa: Mazda, 200o) with Rudi Matthee. She is currently working on a project on the history of medicine, disease, and reproductive health in colonial Egypt.

\section{Philippe Bourmaud}

is Associate Professor in Modern and Contemporary History at the Universite Jean Moulin-Lyon 3. His research focuses on the history of health professions in the late Ottoman and Mandatory Middle East, with a focus on Palestine; the history of expertise in the Middle Eastern mandates; and the history of alcohol in the modern Middle East. His publications include: "La invención de los indicadores internacionales: Salud, problemas sociales y cuantificación en el Cerccano Oriente bajo mandato (1919-1939)," in Mundos arabes en movimiento: Historia del presente, coll. ivestigacion e ideas, eds. Camila Pastor, Gilberto Conde, and Marta Tawil, 291-315 (Mexico: CIDE, 2016); “Turf Wars at the League of Nations: International Anti-Cannabis Policies and Oversight in Syria and Lebanon, 1919-1939," in The League of Nations' Work on Social Issues: Visions, Endeavours and Experiments, eds. Magaly Rodrigues Garcia, Davide Rodogno, and Liat Kozma, 75-87 (Geneva: United Nations, 2016); “Pipe-line, colonialisme et ligne claire: Tintin et la question des mandats du Proche-Orient," in "La BD francophone et le tournant postcolonial," ed. Philippe Delisle, special issue, Outre-mers: Revue d'histoire 392-393, no. 2 (2016): 39-68; With Karène Sanchez Summerer, eds., "Missions, Powers and Arabization," special issue, Social Sciences and Missions 32, nos. 3-4 (2019). 


\section{Seija Jalagin}

holds a PhD from the University of Oulu, Finland (2007) and has been a Docent at the University of Turku, Finland, since 2013. Jalagin works as a Senior Lecturer of History and Japanese Studies at the University of Oulu. She has published extensively on gender and cultural interaction in Christian mission, stereotypes and mental images. Currently, she researches transnational refugee history and is the leader of research project "Recognition and belonging: forced migrations, troubled histories and memory cultures", funded by the Finnish Research Council (2017-2021).

\section{Nazan Maksudyan}

is a Research Associate at the Leibniz-Zentrum Moderner Orient (Berlin). She was a EUME Fellow at the Wissenschaftskolleg zu Berlin in 2009-2010 and an Alexander von Humboldt Stiftung Postdoctoral Fellow at the zMo in 20102011. She worked as an Associate Professor of History at Istanbul Kemerburgaz University (2013-2016). Her research mainly focuses on the history of children and youth in the Ottoman Empire during the 19th and 2oth centuries, with special interest in gender, sexuality, education, humanitarianism, and nonMuslims. Her Orphans and Destitute Children in the Late Ottoman Empire (Syracuse: Syracuse University Press, 2014) treats those who are farthest removed from power as the lead actors in history. She edited Women and the City, Women in the City (New York: Berghahn, 2014). On the history of children, she published "Orphans, Cities, and the State: Vocational Orphanages (Islahhanes) and 'Reform' in the Late Ottoman Urban Space," IJMES 43 (2011): 493-511, and "Foster-Daughter or Servant, Charity or Abuse: Beslemes in the Late Ottoman Empire," Journal of Historical Sociology 21 (2008): 488-512. Currently, she works on the lives of children in the Ottoman Empire during the First World War on which she has published "Agents or Pawns? Nationalism and Ottoman Children during the Great War," Journal of the Ottoman and Turkish Studies Association (JOTSA) 3 (2016): 147-172.

\section{Michael Marten}

Having previously taught at the School of Oriental and African Studies, the University of Pavia, and the University of Stirling, Michael Marten has published widely on Scottish missionary efforts in the Middle East. He was elected a Fellow of the Royal Historical Society in 2015 in recognition of his contribution to this field.

\section{Heleen Murre-van den Berg}

(PhD Leiden, 1995) is director of the Institute of Eastern Christian Studies and Professor of Eastern Christian Studies at Radboud University. She is the 
PI of the ERC Advanced Project "Rewriting Global Orthodoxy: Oriental Christianity in Europe between 1970 and 2020" (2019-2024). Earlier, she held the chair of professor of World Christianity, especially in the Middle East, at Leiden University, where she also served as vice-dean of the Faculty of Humanities. She published extensively on Christianity in the Middle East, especially on the Syriac/Assyrian traditions. Recent publications include (with S.R. GoldsteinSabbah, eds.) Modernity, Minority, and the Public Sphere:Jews and Christians in the Middle East (Leiden: Brill, 2016) and Scribes and Scriptures: The Church of the East in the Eastern Ottoman Provinces (1500-1850) (Louvain: Peeters, 2015). In 2017, she was elected a member of the KNAW (Koninklijke Nederlandse Akademie van Wetenschappen) and she received the Hans Sigrist Prize of the University of Bern.

\section{Inger Marie Okkenhaug}

(PhD University of Bergen, 1999) is a Professor of History at Volda University College, Norway. From 2000 until 2009 Okkenhaug was a researcher at the University of Bergen. She has published a number of chapters and articles on mission, gender, relief and welfare in the Middle East. Among her most recent publications is "Religion, Relief, and Humanitarian Work among Armenian Women Refugees in Mandatory Syria, 1927-1934," Scandinavian Journal of History 40, no. 3 (2015):432-454; "Scandinavian Missionaries in Palestine:The Swedish Jerusalem Society, Medical Mission and Education in Jerusalem and Bethlehem, 1900-1948," in Tracing the Jerusalem Code: Christian Cultures in Scandinavia vol. 3., ed. Ragnhild J. Zorgati (De Gruyter, 2020) and "Orphans, Refugees and Relief in the Armenian Republic, 1922-1925," in Aid to Armenia, eds. Joanne Laycock and Francesca Piana, (Manchester University Press, 2020). Okkenhaug's latest book, "En norskfilantrop": Bodil Biørn og armenerne, 1905-1934 (2016) deals with Norwegian mission and humanitarian work among the Armenians in the years from 1905 to 1940.

\section{Idir Ouahes}

obtained his PhD degree in History from the University of Exeter in 2016. Previously, he studied at Exeter (MRes Middle East Studies) and at London's School of Oriental and African Studies (BA History). Idir published his thesis in 2018 via I.B. Tauris as Syria and Lebanon at the Outset of the French Mandate: Workings of Cultural Imperialism. He has published several peer-reviewed articles, book chapters, and encyclopedia entries. Among these are: "Agricultural Experimentation in French Mandate Syria," in Ecological Networks in Colonial Contexts, c. 1850-1920, eds. Ulrike Kirchberger and Brett Bennett (Durham, NC: University of North Carolina Press, 2019); "Situating the Syrian State: Education \& Citizenship 1914-2014," in Citizenship, Identity \& Nation-States in the 21st Cen- 
tury, eds. Nicole Stokes DuPass and Ramona Fruja, 195-220 (New York: Palgrave, 2016); "Catholic Missionary Education in early French Mandate Syria \& Lebanon," Social Sciences and Missions 30, nos. 3-4 (2017): 225-253; "Une ceinture d' espace étatique: Le contrôle des bédouins au début du Mandat Francais en Syrie," L'Éspace Politique 28 (2015).

\section{Maria Chiara Rioli}

is a Marie Curie post-doctoral fellow at Fordham University and Ca' Foscari Venice University. She was a research associate at the University of Paris-Est Marne-la-Vallée and scientific secretary at "Open Jerusalem", an ERC-funded project. Among her publications are "The 'New Nazis' or the 'People of our God'? Jews and Zionism in the Latin Church of Jerusalem, 1948-1962," Journal of Ecclesiastical History (2017): 81-107; and Ritornare a Israele: Giorgio La Pira, gli ebrei, la Terra Santa (ed., Pisa: Edizione della Normale, 2015).

\section{Karène Sanchez Summerer}

is Associate Professor at Leiden University. She obtained her PhDs from Leiden University and EPHE (Ecole Pratique des Hautes Etudes, Paris, Sorbonne). Her research considers the European linguistic and cultural policies and the Arab communities (1860-1948) in Palestine. She is the PI of the research project "CrossRoads-A connected history between Europeans' cultural diplomacy and Arab Christians in Mandate Palestine" (2018-2022, project funded by the Dutch Research Council Nwo). She is the co-editor of the series Languages and Culture in History with Em. Prof. W. Frijhoff, Amsterdam University Press. From 2015 until 2019, she was the PI of the international project NWO/IEG Mainz/IISMM Paris research project "Engaging Europe in the Middle East: European missionaries and humanitarianism in the Middle East (1850-1970)." Since 2017, she has been one of the coordinators of the MisSMO research program about Christian missions in the Middle East since the late 19th century, https://missmo.hypotheses.org/ "'Missions, Powers and Arabization," eds. with Philippe Bourmaud, special issue, Social Sciences and missions 32, nos. 34 (2019), https://brill.com/view/journals/ssm/32/3-4/article-p229_1.xml). From 2012 until 2017, she researched the role of language among the Palestinian Catholic communities in Palestine, within the Dutch Research Council project "Arabic and its Alternatives", and published: Heleen Murre-van den Berg, Karène Sanchez Summerer, and Tijmen Baarda (eds.), Arabic and its Alternatives: Religious Minorities and their Languages in the Emerging Nation States of the Middle East (1920-1950), Christians and Jews in Muslim Societies 5 (Leiden: Brill, 2020), https://brill.com/view/title/39181; "Linguistic Diversity and Ideologies among the Catholic Minority in Mandate Palestine: Fear of Confusion or 
Powerful Tool?" in "The Fragments Imagine the Nation? Minorities in the Modern Middle East and North Africa" eds. Jordi T. Gorgas and Benjamin T. White, special issue, British Journal of Middle Eastern Studies 43, no. 2 (2016): 191-205.

\section{Bertrand Taithe}

is Professor of History at the University of Manchester and executive director of the Humanitarian and Conflict Response Institute. He researches the history of humanitarian aid and of missionary activities in the field of relief work. He is currently working on a monograph entitled: The Humanitarians a history. His most recent works include: "The Cradle of the New Humanitarian System? International Work and European Volunteers at the Cambodian Border Camps, 1979-1993," Contemporary European History 25, no. 2 (2016): 335358; "The Charity-Mongers of Modern Babylon: Bureaucracy, Scandal, and the Transformation of the Philanthropic Marketplace, c. 1870-1912," Journal of British Studies 54, no. 1 (2015): 118-137, with Sarah Roddy and Julie-Marie Strange; and a monograph with Bloomsbury, Missionary Developmentalism in Secular and Colonial Context: Humanitarian Arab Villages of Algeria and the Legacy of Lavigerie.

\section{Chantal Verdeil}

graduated from the Institut d'Etudes Politiques (Paris). She also graduated in Arabic and History. She is currently Professor at INALCo. She published La mission jésuite du Mont-Liban et de Syrie (1830-1864) (Paris: Les Indes savantes, 2011) and, with Anne-Laure Dupont and Catherine Mayeur-Jaouen, Le Moyen-Orient par les textes (Paris: A. Colin, 2011) and Histoire du Moyen-Orient XIXe-XXIe siècle (Paris: A. Colin, 2016). She just finished a book on the Saint-Joseph University (Beirut, 1875-1923). 


\title{
Introduction
}

\author{
Inger Marie Okkenhaug and Karène Sanchez Summerer
}

During the Israeli-Palestinian War of 1947-1948, relief to Palestinian refugees was not only given by international agencies and non-governmental organizations. Aid also involved Christian mission institutions already historically present and active in the region. This humanitarian reaction of the Christian missions towards people in need was, however, not a new phenomenon. The German Protestant Syrian Orphanage in Jerusalem for example, was founded in 1860 as a response to the civil war in Syria the same year. During the following decades, the orphanage developed into the largest missionary institution in the country. As shown by Roland Löffler, the Syrian Orphanage underwent a "silent metamorphosis" from a Protestant pietistic mission institution into a major undertaking of social service. ${ }^{1}$ This was a typical development in the Middle East, where many Christian missionaries supported welfare activities that involved ideas and practices of improving people's lives, mostly presented as subservient to the preaching of Christianity. Facing major obstacles in their attempt to convert locals, mission organizations increasingly shifted their focus from evangelization to health and education, frequently changing their vocation according to local demands. ${ }^{2}$ Furthermore, some ethnolinguistic minorities from the Middle East who had suffered displacement during World War I (particularly Assyrian and Armenian populations) saw the European sectarianization process of minorities ${ }^{3}$ as opportunities for some sort of local autonomy.

1 Roland Löffler, "The Metamorphosis of a Pietistic Missionary and Educational Institution into a Social Services Enterprise: The Case of the Syrian Orphanage (186o-1945)," in New Faith in Ancient Lands: Western Missions in the Middle East and Early Twentieth Centuries, ed. Heleen Murre-van den Berg (Leiden: Brill, 2006), 151-174.

2 Barbara Reeves-Ellington, Domestic Frontiers: Gender, Reform, and American Interventions in the Ottoman Balkans and the Near East, 1831-1908 (Amherst: University of Massachusetts Press, 2013), 104; Ellen Fleischmann, "Evangelization or Education: American Protestant Missionaries, the American Board, and the Girls and Women of Syria (1830-1910)," in New Faith in Ancient Lands: Western Missions in the Middle East in the Nineteenth and Early Twentieth Centuries, ed. Heleen Murre-van den Berg (Leiden: Brill, 2006), 263-280; Inger Marie Okkenhaug, The Quality of Heroic Living, of High Endeavour and Adventure: Anglican Mission, Women, and Education in Palestine, 1888-1948 (Leiden: Brill, 2002).

3 Laura Robson, Minorities and the Modern Arab World, New Perspectives (Syracuse, NY: Syracuse University Press, 2016), 7. For minorities in the Middle East, Benjamin White, The Emergence of Minorities in the Middle East: The Politics of Community in French Mandate Syria (Edinburgh: Edinburgh University Press, 2011). 
Linked to large diaspora, they appealed to international Christian opinion and together with the emerging humanitarian organizations, like the Near East Relief and the Red Cross, their message was received by a Western audience who donated money to their cause.

This volume intends to trace the historical links between Christian missionaries, the roots of humanitarianism, its different modalities, their use of "humanitarian diplomacy" 4 and local encounters in a Middle Eastern context, considered as fundamental in the history of religious and social politics in a Muslim environment, this particular field being "so connected with the present-day concerns". ${ }^{5}$ The century considered, between $185^{\circ}$ and 1950, represents moments of colonization, war, and conflicts, all formative settings for humanitarian actions. ${ }^{6}$ During this time, Christian missions were seeking new ways to translate their understanding of Christianity, as seen at the World Missionary Conference in Edinburgh in 1910, which put forward a civilizing mission that sought to modernize the world. ${ }^{7}$

The social dimensions of Christian missions in the Middle East have been revisited in several important studies in the last ten to fifteen years. These works, representing a profound change in approach, methodology, and sources, include Beth Baron's The Orphan Scandal: Christian Missionaries and the Rise

4 Dzovinar Kevonian, Réfugiés et diplomatie humanitaire: Les acteurs européens et la scène proche-orientale pendant l'entre-deux-guerres (Paris: Publications de la Sorbonne, 2004).

5 Johannes Paulmann, "Humanity-Humanitarian Reason-Imperial Humanitarianism: European Concepts in Practice," in Humanity: A History of European Concepts in Practice from the Sixteenth Century to the Present, eds. Fabian Klose and Mirjam Thulin (Göttingen: Vandenhoeck \& Ruprecht, 2016), 288.

6 For the role of missionaries during crises in the Middle East, see Johannes Paulmann and Esther Moeller, eds., "Crisis in the Middle East: Religion, Diplomacy and Humanitarianism" special issue, British Journal of Middle East Studies (forthcoming) - part of the same NWo/IEG/IISMm project; Ilana Feldman and Miriam Ticktin, eds., In the name of Humanity: The Governance of Threat and Care (Durham, NC: Duke University Press Books, 2010), 4; Andrew Thompson, "Humanitarian Interventions, Past and Present," in The Emergence of Humanitarian intervention: Ideas and Practice from the Nineteenth Century to the Present, ed. Fabian Klose (Cambridge: Cambridge University Press, 2016), 331-356; Kevin O'Sullivan, Matthew Hilton, and Juliano Fiori, "Humanitarianism in Context," European Review of History 23, nos. 1-2 (2016): 1-15.

7 The World Missionary Conference of Edinburgh in 1910 put forward a civilizing mission that sought to modernize the world, as well as discussions around missionary-state relations. See Brian Stanley, "Church, State and the Hierarchy of 'Civilisation': The Making of the "Missions and Governments", Report at the World Missionary Conference, Edinburgh 1910," in The Imperial Horizons of British Protestant Missions, 1880-1914, ed. Andrew Porter (Cambridge: Eerdmans, Routledge, 2010), 58-84. 
of the Muslim Brotherhood, Barbara Reeves-Ellington's Domestic Frontiers: Gender, Reform, and American Interventions in the Ottoman Balkans and the Near East, 1831-1908, and Paul Sedra's From Mission to Modernity: Evangelicals, Reformers and Education in Nineteenth-Century Egypt. ${ }^{8}$ Even so, the humanitarian actions of Christian missionaries in the Middle East have not yet been studied thoroughly. ${ }^{9}$

Depending on the areas where they intervened, missionaries were frequently consulted on repeated forced migrations. Some were gatekeepers of colonial states, some also distanced themselves from them. The missionaries considered in this volume are not a homogeneous group (some well connected, others more isolated, some international protagonists, some local workers, some obsessed by the nation-state idea, others not). The case studies present various missionaries' networks that, at times, acted simultaneously and on various scales, within a competitive landscape of charities. Examining institutional and individual strategies within national and local contexts will clarify the motives and effects of Christian missions in delivering aid and thus contribute to a new understanding of the history of humanitarianism in the Middle East.

Some studies tackling humanitarianism define it in ways that reflect the present ${ }^{10}$ ("assistance that occurs in the context of disasters [...] applied to emer-

8 These, in addition to Heather J. Sharkey, American Evangelicals in Egypt: Missionary Encounters in an Age of Empire (Princeton, NJ: Princeton University Press, 2008), Norbert Friedrich, Uwe Kaminsky, and Roland Löffler, eds., The Social Dimensions of Christian Missions in the Middle East, Historical Studies of the 1gth and 2oth Centuries, Missionsgeschichtliches Archiv 16 (Stuttgart: Franz Steiner Verlag, 2010); and Ussama S. Makdisi, Artillery of Heaven: American Missionaries and the Failed Conversion of the Middle East (Ithaca, NY: Cornell University Press, 2008).

9 Silvia Salvatici, A History of Humanitarianism, 1755-1989: In the Name of the Others (Manchester: Manchester University Press, 2019). The author mentions that the missionary experience contributed to the archaeology of international humanitarianism, highlighting the links between faith and compassion, through the anti-slavery movement, and the intertwining of secular and religious agendas, in her chapter 2; Matthew Hilton et al., "History and Humanitarianism: A Conversation," Past and Present 241, no. 1 (2018): 138.

10 Michael Barnett, The International Humanitarian Order (London: Routledge, 2010), 2; Michael Barnett and Janice Gross Stein, eds., Sacred Aid: Faith and Humanitarianism (Oxford: Oxford University Press, 2012); O'Sullivan, Hilton, and Fiori “Humanitarianisms 
gency relief and post-conflict recovery") but the term can also be used historically. Many Christian missions discussed the notion of "humanity" in the Arab world, their socially oriented engagement being based on their engagement in local areas in Europe. ${ }^{11}$ Catholic and Protestant missionaries, aiming at regaining the Holy Land by religious, cultural, and philanthropic influence, often ending up producing "unexpected" effects, ${ }^{12}$ established and circulated competing collective narratives in which the notion of humanity was central. ${ }^{13}$ As noted by Johannes Paulmann, "the evolution of modern humanitarianism overlapped with the transformation of philanthropy, which turned toward 'strangers' at home and abroad and became increasingly concerned with efficiency and professionalism". ${ }^{14}$

in Context," 1-15; Michael Barnett, Empire of Humanity: A History of Humanitarianism (Ithaca: Cornell University Press, 2011).

11 See for example the Swedish and British local engagement of missionaries in Palestine, Karène Sanchez Summerer and Inger Marie Okkenhaug, "The Role of Protestant Missionaries during the Great Arab Revolt in Jerusalem and South Palestine (1936-1939) Towards Humanity?" in BJMES special issue, Crisis in the Middle East: Religion, Diplomacy and Humanitarianism, eds. Johannes Paulmann and Esther Moeller (forthcoming). For the Catholic case, 19th century, see for example Katharina Stornig, "Between Christian Solidarity and Human Solidarity: Humanity and the Mobilisation of Aid for Distant Children in Catholic Europe in the Long Nineteenth Century," in Humanity, A History of European Concepts in Practice from the Sixteenth Century to the Present, eds. Fabian Klose and Mirjam Thulin (Göttingen: Vandenhoeck \& Ruprecht, 2016), 265. For the Protestant case, Judith Becker, "Conceptions of Humanity in the Nineteenth-Century German Protestant Missions," in Humanity, A History of European Concepts in Practice from the Sixteenth Century to the Present, eds. Fabian Klose and Mirjam Thulin (Göttingen: Vandenhoeck \& Ruprecht, 2016); Dzovinar, Réfugiés et diplomatie humanitaire, 561; and Roland Löffler, Protestanten in Palästina-Religionspolitik, Sozialer Protestantismus und Mission in den deutschen evangelischen und anglikanischen Institutionen des Heiligen Landes, 1917-1939 (Stuttgart: Kohlhammer, 2008).

12 Heather J. Sharkey, "Introduction: The Unexpected Consequences of Christian Missionary Encounters," in Cultural Conversions: Unexpected Consequences of Christian Missionary Encounters in the Middle East, Africa, and South Asia, ed. Heather J. Sharkey (Syracuse, NY: Syracuse University Press, 2013), 1-26; Friedrich, Kaminsky, and Löffler, The Social Dimensions of Christian Missions in the Middle East; and Löffler, Protestanten in Palästina.

13 On the Christian missionaries' activities among Christian minorities, Greeks, Assyrians and Armenians, see for example Davide Rodogno, Against Massacre: Humanitarian Interventions in the Ottoman Empire, 1815-1914: The Emergence of a Concept and International Practice (Princeton, NJ: Princeton University Press, 2012), 28-31; Derek Hopwood, The Russian Presence in Syria and Palestine, 1843-1914: Church and Politics in the Near East (Oxford: Clarendon Press, 1969); and publications of Nikolay Lisovoy (in Russian). The first American Protestants from the American Board of Commissioners for Foreign Missions arrived in Lebanon in 1819. Makdisi, Artillery of Heaven.

Johannes Paulmann, "Conjunctures in the History of International Humanitarian Aid dur- 
Missions were also influenced and transformed in encounters with other mission societies and local actors. ${ }^{15}$ In her study of the German Kaiserswerth Deaconesses in Beirut, Julia Hauser has, for example, shown how the missionary agenda, in being fundamentally impacted by local factors, underwent considerable transformation in practice. ${ }^{16}$ In addition to the impact of other missions and local demands, the political framework of state and local authorities shaped mission practice and ways of thinking about their mission. During times of war, mission work was transformed to supply immediate relief. During World War I, for example, Scandinavian and Swiss missionaries, representing neutral nations, turned relief workers during the persecutions of Armenians and other minorities in the Ottoman Empire. ${ }^{17}$ After the war and the dissolution of the Ottoman Empire, the League of Nations' mandate system provided a new framework for Catholic and Protestant missions. Humanitarianism in the Middle East was then brought under the ambit of the League of Nations, though humanitarian efforts continued through volunteer and relief organizations. ${ }^{18}$ The Mandate powers in the Middle East, France and Great Britain, both welcomed mission societies as contributors to the development of health and education in the Mandates. ${ }^{19}$

ing the Twentieth Century," Humanity: An International Journal of Human Rights, Humanitarianism, and Development 4, no. 2 (Summer 2013): 215, 217. Available via http://humanity journal.org/wp-content/uploads/2014/06/4.2-Conjunctures-in-the-History-of-Internatio nal-Humanitarian-Aid-during-the-Twentieth-Century.pdf.

15 This volume focuses on the spread of Christian missionaries' humanitarian actions, through their advocacy and practices. The reactions to their actions have been at the centre of several analyses; for the Muslim populations' reactions, see for example Umar Ryad, "A Muslim Response to Missionary Activities in Egypt: With a Special Reference to the Al-Azhar High Corps of 'Ulamâ' (1925-1935)," in New Faith in Ancient Lands: Western Missions in the Middle East in the Nineteenth and Early Twentieth Centuries, ed. Heleen Murre-van den Berg (Leiden: Brill, 2006), 281-307; Stefan Reichmuth, Jörn Rüsen, and Aladdin Sarhan, eds., Humanism and Muslim Culture: Historical Heritage and Contemporary Challenges (Göttingen: Vandenhoek \& Ruprecht, 2012).

16 Julia Hauser, "From Transformation to Negation: A Female Mission in a 'City of Schools,", Journal of World History 27, no. 3 (September 2016): 476-477.

17 Inger Marie Okkenhaug, "Scandinavian Missionaries, Gender and Armenian Refugees during World War One: Crisis and Reshaping of Vocation," Social Sciences and Missions 23, no. 1 (2010): 63-93.

18 For the Armenians, see Keith David Watenpaugh, "The League of the Nations Rescue of Armenian Genocide Survivors and the Making of Modern Humanitarianism, 1920-1927," American Historical Review 1 (2010): 1315-1339.

19 Elizabeth Thompson, "Neither Conspiracy nor Hypocrisy: The Jesuits and the French Mandate in Syria and Lebanon," in Altruism and Imperialism: Western Cultural and Religious Missions in the Middle East, eds. Eleanor H. Tejirian and Reeva Spector Simon (New York: Middle East Institute, 2002), 66-87. 
The Interwar period was a time of transition and reorientation in the missions. The bloodshed of the war years had a global impact, and it was no longer possible to argue that Christianity and civilization were one and the same. ${ }^{20}$ Changing orientation, the humanitarian aspect increasingly came to the forefront of Christian missions. ${ }^{21}$ Regarding missionaries in the Middle East during and after World War I, Keith David Watenpaugh has argued that "while many of the individuals in the theatre of humanitarian action had their origins in the region as missionaries, as did most of the organizers of the humanitarian project of NER, collectively they stood at the culmination of a secular movement in the missionary project, in which the goals and methods of evangelism gave way almost entirely to addressing the suffering of human beings and developing institutions for their care, social development and higher education". ${ }^{22}$ However, the transition from religious to secular forms of Western humanitarianism was not necessarily a one-way phenomenon. ${ }^{23}$ Scandinavian welfare among Armenian refugees and orphans in the 1920 and -3os exemplifies the complexity of faith-based relief work and modern relief. ${ }^{24}$ Another example can be found in Palestine, where British and Swedish missions in Mandatory Palestine continued and in some instances expanded pre-war schools and hospitals, in addition to contributing crucial relief to the poorer segments of the Muslim population in the country. Thus, redefining and accommodating their mission in relation to the interwar scene, but also answering to new international trends regarding how to interpret their agency as Christian missionaries. ${ }^{25}$ The humanitarian actions of Chris-

20 Hilde Nielssen, Inger Marie Okkenhaug, and Karina Hestad Skeie, eds., Protestant Mission and Local Encounters in the Nineteenth and Twentieth Centuries (Leiden: Brill, 2011 ), 19.

21 See Deborah Gaitskell, "Mission by Other Means? Dora Earthy and the Save the Children Fund in the 1930s," in Protestant Mission and Local Encounters in the Nineteenth and Twentieth Centuries, eds. Hilde Nielssen, Inger Marie Okkenhaug, and Karina Hestad Skeie (Leiden: Brill, 2011), 233-258.

22 Keith David Watenpaugh, Bread from Stones. The Middle East and the Making of Modern Humanitarianism (Oakland, CA: California University Press, 2015), 18.

23 The complex processes of change in humanitarian practices during the Interwar period is exemplified by historian Rebecca Jinks' work on relief and Armenian genocide survivors. R. Jinks, “'Marks Hard to Erase:' The Troubled Reclamation of 'Absorbed' Armenian Women, 1919-1927," The American Historical Review 123, no. 1 (February 2018): 122-123. See also R. Skinner and A. Lester, "Humanitarianism and Empire: New Research Agendas," The Journal of Imperial and Commonwealth History 40, no. 5 (2012): 729-747.

24 Inger Marie Okkenhaug, "Orphans, Refugees and Relief in the Armenian Republic, 19221925," in Aid to Armenia, eds. Jo Laycock and Francesca Piana (Manchester: Manchester University Press, forthcoming).

25 See Sanchez Summerer and Okkenhaug, "The Role of Protestant Missionaries during the 
tian missionaries during the Israeli-Palestine War of 1948 and its aftermath is yet another example of encounters in the Middle East being much more complex than a "secular" Western world meeting a "religious" Arab or even Muslim world.

Relief during times of war and conflict, in a similar manner to all humanitarian work, is locally embedded and practiced. ${ }^{26}$ By historicizing and localizing a number of different Christian mission denominations, Catholics and Protestants, from different national backgrounds and humanitarian aid in a specific place, during a specific time-period, we want to contribute to a new understanding of the history of humanitarianism in the Middle East. Branching out from the American and British Protestant-focused studies that have dominated research on Western missions in the Middle East so far, this volume also includes studies from a French Catholic, Vatican, but also a Protestant (Lutheran) Nordic perspective. What were the motivations, aspirations, and aims of various missions' humanitarian practices and how did trends and patterns toward humanitarianism — relief and development—change over time: in Ottoman contexts and under British and French colonial rule? Connected to Europeans' interests and power, to what extent were Christian missions instrumentalized? What was the role of humanitarian actions during the 1948 conflict? The volumes ends with the impact of 1948 , as by this time, in the rest of the Middle East, global humanitarianism had emerged in the context of post-World War II, the creation of the UN and its agencies (and in the case of Palestine, $\mathrm{UNRWA}^{27}$ ), with new understandings of human rights and refugees' priorities, the independence of several Arab countries, and the endorsement by many missionaries of a "development workers" label, after having fulfilled public service/health functions in the colonial settings.

Great Arab Revolt"; Bertrand Taithe, "Pyrrhic Victories? French Catholic Missionaries, Modern Expertise and Secularizing Technologies," in Sacred Aid: Faith and Humanitarianism, eds. Michael Barnett and Janice Gross Stein (Oxford: Oxford University Press, 2012), 166-182.

26 Nefissa Naguib and Inger Marie Okkenhaug, eds., Interpreting Relief and Welfare Activities in the Middle East, 1800-2005-Welfare and Modernity in the Middle East (Leiden: Brill, 2008), 3. See also Davide Rodogno, who argues that humanitarianism should be carefully historicized: "Beyond Relief: A Sketch of the Near East Relief's Humanitarian Operations, 1918-1929," Monde(s) 2, no. 6 (November 2014): 47, https://www.cairn.info/revue-mondes1 -2014-2-page-45.htm.

27 On UnWra, Kjersti G. Berg, "The Unending Temporary. United Nations Relief and Works Agency (UNWRA) and the Politics of Humanitarian Assistance to Palestinian Refugee Camps 1950-2012" (PhD diss., University of Bergen, 2015), 2. 
Chantal Verdeil's article, "Missions, Charity, and Humanitarian Action in the Levant (19th-2oth century)", presents an overview of the different modalities and challenges of the humanitarian dimension of the Catholic missionaries' action in the Middle East (Syria, Palestine, Egypt) from a long-term perspective. Based on a wide range of archives, it offers a portrait of these actions, distinguishing perennial works (relief to poor children, orphans, the sick, prostitutes, domestic workers) from more occasional actions during major crises that shook the region (massacres of 1860 in Mount Lebanon and Damascus, massacres and genocide of Armenians). Verdeil underlines the fact that the financing of these actions was not only European, but largely local, Christian but also Muslim. This article questions the transformations of these relief actions.

The first part, "Advocacy", comprises four chapters, intended to shed light on the rhetoric of the missionaries towards humanitarian actions. It opens with Beth Baron's analysis of freed slave girls' encounters with Presbyterian missionaries in Cairo in the late 188os. Missionaries participated in the struggle to end slavery, in addition to playing a role in the lives of freed slaves; for missionaries, freed slave girls were possible converts and church workers. American missionaries were in Egypt to convert Egyptians, not to free African slaves, but they did intervene by pressuring Copts to free their slaves, giving refuge to rescued slaves. Missionary schools gave shelter to freed slaves where they received a basic education and girls were trained in domestic chores. Some freed slave girls also received professional training and became nurses in mission hospitals. Baron's study shows that the missionaries' humanitarian offer came at a price. The girls were pressured to adopt a new religion and expected to work in "the homes, schools and hospitals of a group that considered them sisters in Christ but racially inferior".

Nazan Maksudyan is also concerned with American missionaries' ideology, aims and practices in late 19th-century Middle East. The focus here is on the American Board of Commissioners for Foreign Missions (ABCFM) and photographs as representations of religious and humanitarian work among Armenians in "Asiatic Turkey" (Anatolia). Maksudyan argues that the bodily conditions of targeted constituencies and their physical surroundings were reconceived and reconceptualized by missionaries as material representations and mirrors of religious and moral progress. What missionaries propagated relied on the bodies and physical surroundings of the Armenians and the main indicator of conversion was a change in the living conditions and customs of the people. Maksudyan argues that the social change that took place as 
a result of American welfare institutions (in education and health) was the essence of conversion itself. Armenians were converted to a certain definition of "civilization" rather than to the Protestant religion. Photography and narrative descriptions of this social change were used as evidence for successful proselytizing.

Protestant mission among Armenians in Anatolia during the late Ottoman period is also the theme of Inger Marie Okkenhaug's article. Based on sources from the Scandinavian branches of the Lutheran Women's Mission Workers' organization, Okkenhaug focuses on how the mission-evangelization, healing, and welfare-was practiced by a Scandinavian female missionary, Bodil Biørn (1871-1960), working in Armenian communities in the Ottoman Empire from 1905 to 1914. As has been shown elsewhere, for American Protestant missionaries who worked in the Ottoman Empire, humanitarian work and missionary enterprise could not be disentangled. ${ }^{28}$ This fusion of evangelization, emergency relief and "longer-term efforts to prevent suffering from famine, illhealth, or poverty"29 also characterized the activities and perceptions of the Scandinavian missionaries in the region.

Heleen Murre-van den Berg's article analyses the British missionary contribution in Iraq via the publications of one of its most vocal representatives, the Rev. W.A. Wigram (1872-1953). His works played an important role in explaining the situation of the Assyrians in the English-speaking world, implicated in the plight of the Assyrians because the British had actively involved them militarily in the Great War. Murre-van den Berg presents a politicized advocacy for the Assyrians of the Church of the East as a vulnerable minority, entitled to the support of Great Britain and the rest of the world. The role of the militarization of the British presence in Iraq, and the militarization of the Assyrians is questioned, as well as the extent of the universalism of humanitarianism within the supposedly special position of (some) Middle Eastern Christians as part of an eschatological reading of the world.

The second part, "Best Practices", analyses missionary networks and how missionaries had an impact on the development of humanitarian practices and law. It also examines how non-missionaries took over, to a certain extent,

28 Flora A. Keshgegian, “'Starving Armenians:' The Politics and Ideology of Humanitarian Aid in the First Decades of the Twentieth Century," in Humanitarianism and Suffering: The Mobilization of Empathy, eds. Richard Ashby Wilson and Richard D. Brown (Cambridge: Cambridge University Press, 2008), 144. See also Nazan Maksudyan's article in this volume.

29 Paulmann, "Conjunctures in the History of International Humanitarian Aid," 215. 
the humanitarian aims and organizations of missionaries, the "NGOization" of Christian missions, when missions "became development", thus re-evaluating the role of religion in their discourses and practices. This part explores the transnational implication of the states on missionaries' activities; how governments used missionaries' ideas involved in development projects during the transition from colonial to mandate to postcolonial rule; and to what extent the League of Nations and its media were linked to the missionaries.

Bertrand Taithe's case study focuses on the creation and theocratic management of Christian model villages populated with Algerian "orphans" from the 1866-1869 famine. The two villages inspired by Middle East missionary activities remained strictly limited as to their impact and symbolic presence in a colonial landscape dominated by secular politics and racial segregation. Following the lives of "rescued" children in these settlements and in the wider world, Taithe stresses the limits of missionary activism and the ambiguous opportunities missionary humanitarianism offered.

In the Interwar period, the Rockefeller Foundation ( $\mathrm{RF}$ ) became a major humanitarian actor in the Middle East, through its support for the New Yorkbased Near East Relief (after 1930, Near East Foundation). Philippe Bourmaud, in his article "Missionary Work, Secularization, and Donor Dependency: Rockefeller-Near East Colleges Cooperation after World War I (1920-1939)", explores the links between the Christian-minded Rockefeller and the missionaries, the $\mathrm{RF}$ choosing the American University of Beirut (AUB) as their main local partner. Thanks to RF funding, the AU B was able to develop ample medical services, partly with a view to providing medical assistance to the refugee populations of the region. Bourmaud analyses how donor dependency has played out for the $\mathrm{RF}$, and compares secular and missionary receptivity to the influence of donors, considering missionary institutions that change their general perspective and become secularized, following professionalized models of philanthropical operation.

American humanitarian activities in the Levant is also the topic of Idir Ouahes, whose article focuses on the U.s. humanitarian, state, and non-state actors' actions in favour of Christian minorities in early 2oth century Syria and Lebanon. Ouahes traces the U.s. enthusiastic and managerial answer and paradigm to World War I, the roots of what was called "Machine Age humanitarianism". "Inevitably, the significant structure given to U.s.-Levant ties through humanitarian aid spilled into the political arena." Ouahes thus puts into perspective the links of different actors around the missionaries, depicting the colonial context of French mandatory authorities, who had taken over from the Ottomans after the war. The French government in Syria and Lebanon "viewed 
such activity suspiciously, though they welcomed the income that enabled them to reduce their state-building obligations".

In a similar manner to the French Mandate government's view of Western missions as welfare agents, the British Mandate government in Palestine also welcomed Christian missionaries' welfare work. For Scottish Presbyterian missionaries in Palestine, medical practice became a way to improve the relationship with the local population. In his article, Michael Marten focuses on Scottish Presbyterian missions to the Jews in Palestine and the Scots' reactions to the humanitarian crisis in the region after World War I. Marten uncovers insights into ways of thinking about what the churches and their missionary committees were doing in this period, as they sought to translate their understanding of Christianity in new ways. During World War I and the immediate aftermath, the Scots engaged in a direct form of humanitarian (ecumenical) relief. Although the United Free Church of Scotland continued to some extent to provide relief during the British Mandate, its focus was also on defending the Church against the increasing Zionist influence in Palestine.

In the epilogue, Seija Jalagin and Maria Chiara Rioli analyse the impact of the 1948 Israeli-Arab conflict in terms of humanitarian actions and refugees among Jews and Arabs and the narratives around humanitarianism and Christian missions.

The theme of Seija Jalagin's article is a Finnish mission in Jerusalem during the 1940s. While the Scottish missions had been active among Jews in Palestine since 1839, the Finnish Protestant mission to the Jews was a relative newcomer to the country, arriving in the 1920s. Headed by Aili Havas (1903-1988), this Protestant mission concentrated solely on the Jews and was, like many other foreign religious actors in the Middle East, both marginal and a grassroots agent. Havas' mission was the establishment of a student home for young Jews to study the Bible and discuss religious issues. With Nazi Germany's annihilation of European Jewry, by 1940 the mission home was transformed into a shelter for Jewish refugees. During the war years, Havas dedicated herself to aiding Jewish refugees. Giving priority to the care of children, the mission's original focus on evangelization was transformed to become a Jewish children's home. In a similar manner to that of the Scottish mission, political and military atrocities in Europe thus permanently changed the Finnish mission agenda in Palestine.

While humanitarianism guided Finnish missionaries' relief work among Jewish Holocaust survivors and refugee families in Jerusalem in 1948, they did not see Arab refugees as worthy of aid. This was in contrast to a number of Catholic institutions in Palestine that established relief operations for 
Arab Palestinians during the Israeli-Palestine conflict in 1947-1948. As shown by Maria Chiara Rioli in her article based on unpublished Catholic archives, mobilizing to assist the Palestinian refugees was not only achieved by international agencies and non-governmental organizations but also involved the complex and variegated web of Christian institutions already historically present and active in the region. Rioli, who writes on the history of the Catholic church and relief in Jerusalem, and specifically the Franciscan Casa Nova, points out that even if the Christian missions' involvement in the Palestinian refugee crisis was relatively small when compared to the new international agencies, "convents, schools, hospitals operated by religious congregations or directly by the local Churches of various rites and denominations were among the first places to receive and aid the Palestinian refugees". Rioli's analysis of the plurality of the Catholic presence makes it possible to retrace many threads of inquiry in the ecclesiastical archives in the Middle East and elsewhere.

\section{3}

\section{Concluding Remarks}

One of the central activities of mission-related humanitarianism from the 186os onward, concerned the question of relief and refugees of the Middle East, due to the repetitive nature of forced migration since the $185 \mathrm{os}$, producing an expertise still relevant today. Several of the contributions to this anthology focus on missions, refugees and relief from the civil war in Syria in 1860, the persecutions of Armenians in the 189os, aid to refugees from World War II and the Palestinian-Israeli War. In 1947-1948, Christian missions, long present in the region, contributed relief to Palestinian refugees alongside international agencies and non-governmental organizations. The humanitarian actions of Christian missionaries during the war of 1948 and its aftermath are an example of encounters in the Middle East being much more complex than a "secular" Western meeting a "religious" Arab or even Muslim world. Our anthology seeks to discover and retrace such "entangled histories" for the first time in an integral perspective.

Although significant on a local scale until the end of the World War I and later on also at a transnational level, the role of Catholic missions has been underestimated from the point of view of medical action, ${ }^{30}$ partially resulting

3o From 1925, by Pope Pius XI himself, who recommended the use of medicine in the missionary setting, U. Bertini, Pie XI et la médecine au service des missions (Paris: Librairie Bloud 
from the impression that the Papacy itself was ambivalent with regard to work that could distract missionaries from their pastoral mission. The opening of the Vatican archives for the period 1939-1958, in March 2020, will be a formative period for the connected history of Christian missions and humanitarianism, the analysis of the NGOization of certain Christian missions and intertwined aspects of religious, medical, and humanitarian networks. ${ }^{31}$

\section{Bibliography}

Barnett, Michael. The International Humanitarian Order. London: Routledge, 2010.

Barnett, Michael. Empire of Humanity: A History of Humanitarianism. Ithaca: Cornell University Press, 2011.

Barnett, Michael, and Janice Gross Stein, eds. Sacred Aid: Faith and Humanitarianism. Oxford: Oxford University Press, 2012.

Baron, Beth. The Orphan Scandal: Christian Missionaries and the Rise of the Muslim Brotherhood. Stanford, CA: Stanford University Press, 2014.

Becker, Judith. "Conceptions of Humanity in the Nineteenth-Century German Protestant Missions." In Humanity: A History of European Concepts in Practice from the Sixteenth Century to the Present, edited by Fabian Klose and Mirjam Thulin, 107-130. Göttingen: Vandenhoeck \& Ruprecht, 2016.

Berg, Kjersti G. "The Unending Temporary: United Nations Relief and Works Agency (UNWRA) and the Politics of Humanitarian Assistance to Palestinian Refugee Camps 1950-2012." PhD diss., University of Bergen, 2015.

Bertini, U. PiexI et la médecine au service des missions. Paris: Librairie Bloud et Gay, 1930. Feldman, Ilana, and Miriam Ticktin, eds. In the Name of Humanity: The Governance of Threat and Care. Durham, NC: Duke University Press Books, 2010.

et Gay, 1930); C. Prudhomme, Missions chrétiennes et colonisation: $\mathrm{XVI}-\mathrm{XX}{ }^{\mathrm{e}}$ siècles (Paris: Editions du Cerf, 2004).

31 The Prefet of the Secret Archives of the Vatican, Bishop Sergio Pagano, referred in his speech of 4 March 2019 (http://www.osservatoreromano.va/vaticanresources/pdf/QUO _2019_053_0503.pdf, accessed 31 January, 2020) announcing the opening of the post-1938 Vatican archives (1939-1958), to a "charity diplomacy". The Press Office of the Holy See mentioned special archival collections that will be of interest of researchers. "The first is that of the Relief Commission, the second is simply called Pontifical Charity, and the third is that of the Migration Office, set up to deal with the problem of the repatriation of prisoners and refugees, as well as the growing issue of migration". Files: Commissionne soccorsi 1939-1958; Beneficenza pontificia 1939-1968 busta IV Associazioni chiesi istituzioni; Ufficio migrazione 1946-1966; Pontificia Opera di assistenza 1944-1970; Opera Nazionale per l'Assistenza religiosa e morale degli operai $1926-195^{2}$. 
Fleischmann, Ellen. "Evangelization or Education: American Protestant Missionaries, the American Board, and the Girls and Women of Syria (1830-1910)." In New Faith in Ancient Lands: Western Missions in the Middle East in the Nineteenth and Early Twentieth Centuries, edited by Heleen Murre-van den Berg, 263-28o. Leiden: Brill, 2006.

Friedrich, Norbert, Uwe Kaminsky, and Roland Löffler, eds. The Social Dimensions of Christian Missions in the Middle East: Historical Studies of the 19th and 2oth Centuries. Missionsgeschichtliches Archiv, 16. Stuttgart: Franz Steiner Verlag, 2010.

Gaitskell, Deborah. "Mission by Other Means? Dora Earthy and the Save the Children Fund in the 1930s." In Protestant Mission and Local Encounters in the Nineteenth and Twentieth Centuries, edited by Hilde Nielssen, Inger Marie Okkenhaug, and Karina Hestad Skeie, 233-258. Leiden: Brill, 2011.

Hauser, Julia. "From Transformation to Negation: A Female Mission in a 'City of Schools." Journal of World History 27, no. 3 (September 2016): 473-496.

Hilton, Matthew, Emily Baughan, Eleonor Davey, Bronwen Everill, Kevin O'Sullivan, and Tehila Sasson. "History and Humanitarianism: A Conversation." Past and Present 241, no. 1 (2018): 1-38.

Hopwood, Derek. The Russian Presence in Syria and Palestine, 1843-1914: Church and Politics in the Near East. Oxford: Clarendon Press, 1969.

Jinks, R. “'Marks Hard to Erase:' The Troubled Reclamation of 'Absorbed' Armenian Women, 1919-1927." The American Historical Review 123, no. 1 (February 2018): 86123.

Keshgegian, Flora A. “'Starving Armenians:' The Politics and Ideology of Humanitarian Aid in the First Decades of the Twentieth Century." In Humanitarianism and Suffering: The Mobilization of Empathy, edited by Richard Ashby Wilson and Richard D. Brown, 140-155. Cambridge: Cambridge University Press, 2008.

Kevonian, Dzovinar. Réfugiés et diplomatie humanitaire: Les acteurs européens et la scène proche-orientale pendant l'entre-deux-guerres. Paris: Publications de la Sorbonne, 2004.

Löffler, Roland. "The Metamorphosis of a Pietistic Missionary and Educational Institution into a Social Services Enterprise: The Case of the Syrian Orphanage (186o1945)." In New Faith in Ancient Lands: Western Missions in the Middle East and Early Twentieth Centuries, edited by Heleen Murre-van den Berg, 151-174. Leiden: Brill, 2006.

Löffler, Roland. Protestanten in Palästina: Religionspolitik, Sozialer Protestantismus und Mission in den deutschen evangelischen und anglikanischen Institutionen des Heiligen Landes, 1917-1939. Stuttgart: Kohlhammer, 2008.

Makdisi, Ussama S. Artillery of Heaven: American Missionaries and the Failed Conversion of the Middle East. Ithaca, NY: Cornell University Press, 2008.

Naguib, Nefissa, and Inger Marie Okkenhaug, eds. Interpreting Relief and Welfare Activ- 
ities in the Middle East, 1800-2005: Welfare and Modernity in the Middle East. Leiden: Brill, 2008.

Nielssen, Hilde, Inger Marie Okkenhaug, and Karina Hestad Skeie, eds. Protestant Mission and Local Encounters in the Nineteenth and Twentieth Centuries. Leiden: Brill, 2011.

Okkenhaug, Inger Marie. The Quality of Heroic Living, of High Endeavour and Adventure: Anglican Mission, Women, and Education in Palestine, 1888-1948. Leiden: Brill, 2002.

Okkenhaug, Inger Marie. "Scandinavian Missionaries, Gender and Armenian Refugees during World War One: Crisis and Reshaping of Vocation." Social Sciences and Missions 23 , no. 1 (2010): 63-93.

Okkenhaug, Inger Marie. "Orphans, Refugees and Relief in the Armenian Republic, 1922-1925." In Aid to Armenia, edited by Jo Laycock and Francesca Piana. Manchester: Manchester University Press, forthcoming.

O'Sullivan, Kevin, Matthew Hilton, and Juliano Fiori. "Humanitarianism in Context." European Review of History 23, nos. 1-2 (2016): 1-15.

Paulmann, Johannes. "Conjunctures in the History of International Humanitarian Aid during the Twentieth Century." Humanity: An International Journal of Human Rights, Humanitarianism, and Development 4, no. 2 (Summer 2013): 215-238. Available via http://humanityjournal.org/wp-content/uploads/2014/o6/4.2-Conjun ctures-in-the-History-of-International-Humanitarian-Aid-during-the-Twentieth-C entury.pdf.

Paulmann, Johannes. "Humanity-Humanitarian Reason-Imperial Humanitarianism: European Concepts in Practice." In Humanity: A History of European Concepts in Practice from the Sixteenth Century to the Present, edited by Fabian Klose and Mirjam Thulin, 287-312. Göttingen: Vandenhoeck \& Ruprecht, 2016.

Paulmann, Johannes, and Esther Moeller, eds. "Crisis in the Middle East: Religion, Diplomacy and Humanitarianism." Special issue, British Journal of Middle East Studies (forthcoming).

Prefet of the Secret Archives of the Vatican. Bishop Sergio Pagano's speech of 4 March 2019. Available via http://www.osservatoreromano.va/vaticanresources/pdf/QUO_ 2019_053_0503.pdf.

Prudhomme, C. Missions chrétiennes et colonisation: $\mathrm{XVI}-\mathrm{XX} \mathrm{e}^{\mathrm{e}}$ siècles. Paris: Editions du Cerf, 2004.

Reeves-Ellington, Barbara. Domestic Frontiers: Gender, Reform, and American Interventions in the Ottoman Balkans and the Near East, 1831-1908. Amherst: University of Massachusetts Press, 2013.

Reichmuth, Stefan, Jörn Rüsen, and Aladdin Sarhan, eds. Humanism and Muslim Culture: Historical Heritage and Contemporary Challenges. Göttingen: Vandenhoek \& Ruprecht, 2012. 
Robson, Laura. Minorities and the Modern Arab World, New Perspectives. Syracuse, NY: Syracuse University Press, 2016.

Rodogno, Davide. Against Massacre: Humanitarian Interventions in the Ottoman Empire, 1815-1914: The Emergence of a Concept and International Practice. Princeton, NJ: Princeton University Press, 2012.

Rodogno, Davide. "Beyond Relief: A Sketch of the Near East Relief's Humanitarian Operations, 1918-1929." Monde(s) 2, no. 6 (November 2014): 45-64. https://www .cairn.info/revue-mondes1-2014-2-page-45.htm.

Ryad, Umar. "A Muslim Response to Missionary Activities in Egypt: With a Special Reference to the Al-Azhar High Corps of 'Ulamâ' (1925-1935)." In New Faith in Ancient Lands: Western Missions in the Middle East in the Nineteenth and Early Twentieth Centuries, edited by Heleen Murre-van den Berg, 281-307. Leiden: Brill, 2006.

Sanchez Summerer, Karène, and Inger Marie Okkenhaug. "The Role of Protestant Missionaries during the Great Arab Revolt in Jerusalem and South Palestine (19361939) - Towards Humanity?" In "Crisis in the Middle East: Religion, Diplomacy and Humanitarianism," edited by Johannes Paulmann and Esther Moeller. Special issue, BJMES (forthcoming).

Salvatici, Silvia. A History of Humanitarianism, 1755-1989: In the Name of the Others. Manchester: Manchester University Press, 2019.

Sharkey, Heather J. American Evangelicals in Egypt: Missionary Encounters in an Age of Empire. Princeton, NJ: Princeton University Press, 2008.

Sharkey, Heather J. "Introduction: The Unexpected Consequences of Christian Missionary Encounters.” In Cultural Conversions: Unexpected Consequences of Christian Missionary Encounters in the Middle East, Africa, and South Asia, edited by. Heather J. Sharkey, 1-26. Syracuse, NY: Syracuse University Press, 2013.

Sedra, Paul. From Mission to Modernity. Evangelicals, Reformers and Education in Nineteenth-Century Egypt. London: I.B. Tauris, 2011.

Skinner, Rob, and Alan Lester. "Humanitarianism and Empire: New Research Agendas." The Journal of Imperial and Commonwealth History 40, no. 5 (2012): 729-747.

Stanley, Brian. "Church, State and the Hierarchy of 'Civilisation:' The Making of the 'Missions and Governments' Report at the World Missionary Conference, Edinburgh 1910." In The Imperial Horizons of British Protestant Missions, 1880-1914, edited by Andrew Porter, 58-84. Cambridge: Eerdmans, Routledge, 2010.

Stornig, Katharina. "Between Christian Solidarity and Human Solidarity: Humanity and the Mobilisation of Aid for Distant Children in Catholic Europe in the Long Nineteenth Century." In Humanity: A History of European Concepts in Practice from the Sixteenth Century to the Present, edited by Fabian Klose and Mirjam Thulin, 249266. Göttingen: Vandenhoeck \& Ruprecht, 2016.

Taithe, Bertrand. "Pyrrhic Victories? French Catholic Missionaries, Modern Expertise and Secularizing Technologies." In Sacred Aid: Faith and Humanitarianism, edited 
by Michael Barnett and Janice Gross Stein, 166-187. Oxford: Oxford University Press, 2012.

Thompson, Andrew. "Humanitarian Interventions, Past and Present." In The Emergence of Humanitarian intervention: Ideas and Practice from the Nineteenth Century to the Present, edited by Fabian Klose, 331-356. Cambridge: Cambridge University Press, 2016.

Thompson, Elizabeth. "Neither Conspiracy nor Hypocrisy: The Jesuits and the French Mandate in Syria and Lebanon." In Altruism and Imperialism: Western Cultural and Religious Missions in the Middle East, edited by Eleanor H. Tejirian and Reeva Spector Simon, 66-87. New York: Columbia University Middle East Institute, 2002.

Watenpaugh, Keith David. "The League of the Nations Rescue of Armenian Genocide Survivors and the Making of Modern Humanitarianism, 1920-1927." American Historical Review 1 (2010): 1315-1339.

Watenpaugh, Keith David. Bread from Stones: The Middle East and the Making of Modern Humanitarianism. Oakland, CA: California University Press, 2015.

White, Benjamin. The Emergence of Minorities in the Middle East: The Politics of Community in French Mandate Syria. Edinburgh: Edinburgh University Press, 2011. 
- 978-90-04-43453- 0

Downloaded from Brill.com04/26/2023 01:14:44PM via free access 
PART 1

Prologue 
- 978-90-04-43453- 0

Downloaded from Brill.com04/26/2023 01:14:44PM via free access 


\title{
Missions, Charity, and Humanitarian Action in the Levant (19th-2oth Century)
}

\author{
Chantal Verdeil
}

\section{Introduction}

There is nothing new about the idea of continuity between the missionary apostolate and humanitarian action. Writing of the crisis of the Catholic missions at the time of colonial independence, some 15 years ago, Claude Prudhomme noted that the mid-2oth century marked the "end of an era and of the European missionary utopia [...]. Unless humanitarian intervention constitutes a last attempt to reactivate the missionary spirit".1

A missionary territory for many centuries, the Middle East is particularly fertile ground for these ideas in that it is seen as one of the cradles of European and Us humanitarian action. ${ }^{2}$ At the beginning of the 2000 , this area saw the emergence of large numbers of NGOs, usually seen as a sign of the vitality of "civil society" and as the outcome of the relative disengagement of the state from the social domain, in a context that was economically liberal and politically authoritarian. Hamit Bozarslan, for instance, sees NG o s as a "route whereby the authorities attempt to depoliticize the social or to promote charity as the only way to overcome economic and social problems of which they have washed their hands". ${ }^{3}$

Today, the idea that "Religion might have been instrumental in the establishment of humanitarianism, but it passed the torch to secularism" ${ }^{4}$ (via the NGO) is disputed: many missionary or religious organizations are very active

1 Claude Prudhomme, "Quand triomphe la mission: autopsie d'un succès," in Une appropriation du monde: Mission et Missions, XIXème-XXème siècles, ed. Claude Prudhomme (Paris: Publisud, 2004), 15 .

2 Davide Rodogno, Against Massacre, Humanitarian Interventions in the Ottoman Empire, 18151914: The Emergence of a European Concept and International Practice (Princeton: Princeton University Press, 2012).

3 Hamit Bozarslan, Sociologie politique du Moyen-Orient (Paris: La Découverte, 2011), 58.

4 Michael Barnett and Janice Gross Stein, "Introduction: The Secularization and Sanctification of Humanitarianism," in Sacred Aid: Faith and Humanitarianism, eds. Michael Barnett and Janice Gross Stein (Oxford: Oxford University Press, 2012), 3-36. 
in humanitarian work alongside NGO s with no religious affiliation: the former have not "passed the torch" to the latter. The process of secularization, if secularization there is, does not lead to an eradication of the religious actors, nor to a decline in their power to mobilize and their capacity to act. Rather than a passing of the baton, therefore, we need to think in terms of influence and explore the impact of missionaries on the development of humanitarian practices and law. If we reverse the perspective and look at the development of missionary practices, in particular since colonial independence, and at the influence of NGOS on their methods of operation, the transformation of certain missionary congregations (or at least of some of their activities) can be described as a "NGOization". For example, according to Louis Audet-Gosselin, the fact that the Catholic Church in Burkina Faso was able to maintain its influence in Burkinabé society is because it relied on the conversion of congregations to non-governmental organizations, as well as on the arrival of new congregations and NGO s. ${ }^{5}$

In the comparison between humanitarian organization and mission, research has primarily focused on the forms of their "charitable" or "humanitarian" action, on their ideals, on the bureaucratic or professional nature of their operations. ${ }^{6}$ Here, we wish to explore the material, and more specifically the financial, dimension of missionary activity, making this the subject of the invitation issued by Sarah Ben-Néfissa to researchers interested in NGO s: because NGO $\mathrm{s}$ are "intermediaries between funding agencies and populations", it is important "to study their 'social capital' and their networks of upward and downward relations". What image of the charitable activity of missionaries emerges if we look at their methods of funding? How do the missionaries use their social capital? Do they have access to "funding agencies"? Through what channels?

To answer these questions, this article first provides an overview of the humanitarian (charitable) action of the missionaries in the Middle East and in the Maghreb (Syria, Palestine, Egypt, Turkey, Algeria) during the golden age of the Christian missions to the Middle East (broadly the years 1880-1930), in order to highlight both its diversity and its spiritual and material character. It then examines the funding of these activities, which came not only from Europe and America, but also from substantially local, Christian but also Muslim, sources. Finally, it shows the genuine skills of the missionaries in "fundraising", know-how that was necessary to the maintenance and even more to the development of their charitable works.

5 Louis Audet-Gosselin and Marie Nathalie LeBlanc, Faith and Charity: Religion and Humanitarian Assistance in West Africa (London: Pluto Press, 2016).

6 Barnett, "Introduction," 7. 
In Christianity, Charity is a theological virtue, indissociably linked with the love of God and one's neighbour, spiritual and material. In France, until the beginning of the 19th century, the care of the poor (the sick, orphans, prisoners, the destitute) was undertaken by religious congregations. It gradually became more secular during the 19th century, under the description bienfaisance (corresponding to the English "do-gooding"). ${ }^{7}$ Through missionary activity, religious congregations continued to pursue charitable activities: even though not much used by the missionaries, who spoke of their poor, the word charity was a way to highlight the indissociably material and spiritual nature of their work. What role does charity play in the apostolate of the Christian missionaries? What is their attitude to poverty? Who are their poor?

In the 19th century, the work of the Christian missionaries in the Middle East was dominated by education and health. Schools, colleges, universities, dispensaries, hospitals occupied most of the personnel and received the majority of the resources of the missions. Educational and health institutions had a charitable dimension because they took in the "poor", although they were not solely attended by the most destitute sections of the local population. Alongside these institutions, other activities were more clearly charitable in nature: orphanages, shelters for prostitutes, the visiting of prisoners, support for unskilled workers. If we wish to explore the charitable dimension of the work of the Christian missionaries, we must begin by considering the population - whether destitute or marginal - they were addressing. The missionaries' day-to-day "charity" was aimed first of all at poor children, whether orphans or from poor families, the sick, prostitutes or domestic servants, unskilled male and female workers.

The Christian ministries founded several orphanages as part of their activities in the Middle East. This occurred particularly after the big humanitarian crises that affected the region (confrontations between Druze and Maronites in 1860, genocides and massacres during the First World War, expulsion of the Palestinians from the new state of Israel in 1948 ...). After 1860, the Jesuits founded a boys' orphanage at Bikfaya in Mount Lebanon while the Daughters of Charity opened a similar institution in Beirut, which was soon employing a weaver, a tailor, a cobbler, a carpenter, in order to "train good Christians and good workers who would later be capable of earning an honest living and sup-

7 Chrisitan Felkay, “Filles de la Charité et bureaux de bienfaisance parisiens (1796-186o)," in Des Filles de la Charité aux Soeurs de Saint-Vincent de Paul, quatre siècles de Cornettes, ed. Matthieu Bréjon de Lavergnée (Paris: Honoré Champion, 2016), 391-404. 
porting their families". 8 In Egypt, there was the Presbyterian Fowler Orphanage, named after its first donors, a Quaker couple, Esther and John Fowler, who offered \$8ooo to Margaret (Maggie) Smith (from the American Presbyterian mission) to found an orphanage. Managed by Margaret Smith until the 1920s, then by Ellen Barnes, it was home to some 30 children until the First World War. ${ }^{9}$

In Alexandria, the Salesians of Don Bosco opened an arts and crafts school in 1897 for "sons of the people" whom they sought to turn into "good Christians and honest workers". ${ }^{10}$ In 1901-1902, $20 \%$ of the pupils were orphans, 20 years later the figure was $50 \%$. The aim of the missionaries was to teach these "poor children" a trade, but also to dispense moral instruction:

To have intelligent, educated workers, confident in their future and convinced that it depends on their virtues, on their constancy in their work and a solid faith, is the desire of all those who have the good of society in their heart. This was the purpose of the establishment of the Don Bosco Institute in Alexandra. [...] Thus will be fulfilled the wishes of all the noble and generous people who, having in their heart the good of the country, which depends on the proper direction of the youth of different conditions, regretted the absence of an establishment that would take care of young people of humble origin, destined later on to occupy an honoured place within the working class. ${ }^{11}$

Poor children could also be admitted to the missionary schools through a system of equalization that made it possible to keep classes open for modest families thanks to the fees paid by families from a more comfortable social background. In Damascus, the Daughters of Charity school had a dual curriculum. To girls "whose parents were relatively well-off", the sisters taught French and Arabic, history, geography, arithmetic, music, and drawing. For poorer children,

8 "Letter from Sister Meyniel, Daughter of Charity," Bulletin de l'Oeuvre des Ecoles d'Orient, November $1883,167-172$.

9 Beth Baron, "Orphans and Abandoned Children in Modern Egypt," in Interpreting Welfare and Relief in the Middle East, eds. Nefissa Naguib and Inger Marie Okkenhaug (Leiden, Boston: Brill, 2008), 13-34.

10 Annalaura Turiano, "De la pastorale migratoire à l' enseignement technique, missionnaires italiens en Égypte: Les salésiens et l' enseignement professionnel (189o-1970)" (PhD diss., Aix-Marseille Université, Aix-en-Provence, 2016).

11 ASC $\mathrm{F}_{3} 8_{3}$, Arts and crafts schools. Origins and objectives of the Institute, cited by Annalaura Turiano, "État, réformistes et philanthropes: Les enjeux de l'enseignement professionnel en Égypte au tournant du Xx ${ }^{\mathrm{e}}$ siècle," Histoire de l'Éducation 148 (2018). 
"all those whose families were not so concerned with education", the general education was less extensive, leaving more space for manual skills "proper to their condition".12

The missionaries also often ran hospitals, which cared for patients from all social categories. At the end of the 19th century, the Anglican missionary hospital in Hebron, founded in 1891, was the district's only hospital, and would remain so right through to the end of the British Mandate. This hospital not only admitted the poorest populations but was also intended as a place for activities of evangelization. These two objectives, caring for the sick and evangelizing society, sometimes proved irreconcilable. The accusations diminished after 1846 when the authorities found in favour of the nuns, but they continued to circulate. ${ }^{13}$

Other categories of population, whether marginal or working class, were also the target of the missionaries' apostolate. In the middle of the century in Cairo, the Filles de la Charité du Bon Pasteur d'Angers had created a "charity for negresses", which took in slaves from Nubia, Sudan, or other regions of Africa, freed them and gave them a "Christian education". Many of them, "maltreated by the traders" died "in the arms of the nuns". This activity was subsequently passed on to the Soeurs de Saint-Joseph de l'Apparition. ${ }^{14}$ On their arrival in Beirut, the Daughters of Charity visited the city's prison, where typhoid was rife. They were usually accompanied by a doctor responsible for providing care. A postcard published by the Capuchin mission in Syria during the interwar period also illustrates their work in favour of the poor, the "destitute", through the distribution of food (Figure 1.1).

In Tripoli, the Daughters of Charity built a silk mill where they hoped to train some of the girls who would subsequently work in other similar institutions once established. Male workers were also the target of a "congregation" founded by a Jesuit priest, Father Fiorovich (1818-1898), at the end of the 19th

12 "Letter from Sister Marie, Daughter of Charity, Superior of the Saint Joseph house in Damas," Bulletin de l'Oeuvre des Ecoles d'Orient, January 1887, 15-17.

13 Claire Fredj, "Une présence hospitalière en territoire colonial, les Filles de la Charité en Algérie (1842-1962)," in Des Filles de la Charité aux Soeurs de Saint-Vincent de Paul, quatre siècles de Cornettes, ed. Matthieu Bréjon de Lavergnée (Paris: Honoré Champion, 2016), 456-457.

14 L. Cosnier, Le Bon-Pasteur d'Angers en Égypte: L'œuvre des Écoles d'Orient (Angers: Librairie Lachèse et Dolbeau, 1882), 7; Beth Baron, "Liberated Bodies and Saved Souls: Freed African Slave Girls and Missionaries in Egypt," in African Communities in Asia and the Mediterranean: Identities between Integration and Conflict, ed. Ehud R. Toledano (Halle: Max Plank Institute, 2011). 
century, the congregation of Our Lady of the Seven Sorrows, which brought together the city's "humble working folk", porters, shoe shiners, print workers ... Its recruitment was strictly confessional: the aim was to give spiritual support to an often migrant male Catholic population, whose rootlessness, poverty, and social precariousness were seen by the monks as a threat to faith and morality. The congregation offered or imposed on them exercises in piety (masses, sermons, pilgrimages ...) while at the same time introducing forms of solidarity between its members. The city was divided into four districts, each with its inspectors or delegates responsible for visiting the sick, providing aid to the needy, smoothing over any quarrels and monitoring the congregations by dissuading them, for example, from sending their children to schools run by Protestant missionaries. ${ }^{15}$

This rapid outline of the missionaries' charitable activities does not offer a comprehensive overview of all the missionaries' work in the Middle East. It ignores their work in providing exceptional relief, distributed in times of crisis: our aim here was to look at their day-to-day activities. However, it shows the diversity of their targets: men, women, children or young people (girls or boys), the sick and the healthy. The elderly seem relatively absent, perhaps because there were few of them in the hospitals: the European or American clergy were above all interested in the young, who it is true formed the majority of the population. These charitable activities bear witness to economic activity and demographic changes in the region: the development of the port of Beirut, which attracted numerous migrants, the cultivation of silk in Mount Lebanon, the high death rate everywhere, the persistence of slavery (especially in Egypt), the development of healthcare and educational institutions. In the eyes of the missionaries, relief was not only material, but also spiritual: charity was a moral and religious task.

\section{The Funding of Missionary Charity: Local and International Funding}

How was this charity funded? Apart from the diversity of the congregations, Catholic or Protestant, is it possible to outline a general pattern of activity? In order to do this, we need to look at the operation of the missions and their funding. However, it has to be recognized that the question of the funding of the

15 Michel Jullien sj, La nouvelle mission de la Compagnie de Jésus en Syrie, 1831-1895 (Tours: Imprimerie Mame et Fils, 1899). 
missions has not attracted much scholarly attention. In French historiography, which focuses above all on Catholic missions, these financial questions have cast light on the support given by the French government and notably the anticlerical Republic to the missionary charities, ${ }^{16}$ whereas in the history of the Protestant missions, this aspect-essential as it is—usually remains in the background. Nonetheless, research has highlighted the diversity of these sources of revenue, which reflects both the local grounding of the missions and their ability to maintain close links with potential donors in their countries or with their home Churches. On the subject of the Daughters of Charity in Algeria, Claire Fredj notes that their resources were extremely varied: "investments, income from land, profits from sewing rooms, boarding houses, lessons, income from the work of the nuns, especially their payment [as nurses in civilian or military hospitals]". ${ }^{17}$

It has to be said that the available archives do not always make life easy for historians. Even those of the Society of Jesus, albeit known as a formidable bureaucracy, do not tell us the precise budget of the Jesuit mission in Syria, and in the absence of information it is not certain that the superiors of the order themselves had an accurate and reliable idea of it. A precise study of its operation shows that many of the clergy enjoyed a great deal of autonomy and approached donors via their own networks, in other words short-cutting their hierarchy which was, at least theoretically, supposed to centralize all requests and receive all contributions before distributing the money collected among everyone. ${ }^{18}$ From the example of the Jesuit mission in Syria, combined with other research, it is nevertheless possible to clarify the financial management of a missionary enterprise. What were its sources of revenue? How did it obtain them?

These sources of revenue can be divided into several categories, depending on their geographical origin and the status of the donors. With regard to geography, we will differentiate between revenues from local society (donations, school fees, sales of books or leaflets) and those originating from abroad, from Europe or the United States. With regard to the donors, we can differentiate between individuals and the states that supported the missions or contributed to their funding.

16 Notably Patrick Cabanel, Une France en Méditerranée (Paris: Créaphis, 20o6); Jacques Thobie, Les intérêts culturels français dans l'Empire ottoman finissant (Leuven: Peeters, 2008).

17 Fredj, "Une présence hospitalière en territoire colonial," 452.

18 Chantal Verdeil, La mission jésuite du Mont-Liban et de Syrie (1830-1864) (Paris: Les Indes Savantes, 2011). 
We will begin by looking at the local dimension of the funding of the missions and of their charitable works. Within the missions, budgets were not clearly separated, and a flourishing activity could be used to fund a less lucrative one. The silk mill that the Daughters of Charity ran in Tripoli was also to enable them to "support [their] internal children".19

In the Jesuit mission in Syria, the printing press generated profits that were reallocated to proselytizing activities and to the small schools. Nonetheless, these schools were very largely financed by the families of the students, who saw education as a new form of investment. In the most modest classes, for example in Mount Lebanon, some of this funding came in kind, with the locally recruited teachers being compensated by the villagers in the form of accommodation, food, and sometimes a few clothes (in particular shoes). In this case, the role of the Jesuits who ran this network of schools was not to teach but to supervise the operation of the classes: they made sure that both parties fulfilled their undertakings and acted as intermediaries to resolve disputes in the event of conflict. ${ }^{20}$ In the urban centres, where the missionaries taught in the classes, part of the funding also came from the families. In 1896, the revenue side of the budget of the primary classes at Saint-Joseph University, a Jesuit institution which-despite its name-mainly educated children aged 8 to 18 , consisted chiefly of school fees paid by the pupils. The cost of full board in that case was 600 francs, but there were reductions available for students on half board and day pupils. In all, the fees paid by the families of the students amounted to 113 ,ooo francs, $82 \%$ of the institution's revenues (elementary, primary, and secondary levels). Within this educational establishment, as in most of the Catholic missionary schools, there was a system of equalization that was used to pay for the schooling of pupils from the poorest backgrounds. The "paying" pupils paid for the "free" pupils. ${ }^{21}$ Moreover, this system functioned along confessional lines: discounts were never granted to Muslims or non-Catholic Christians. Muslims and Greek Orthodox families thus indirectly financed the schooling of the poorest Catholics.

This "solidarity" on the part of the socially well-to-do did not stop at the school gates. The missionaries knew how to use their networks to help pupils

\footnotetext{
19 "Letter from Sister Ramel, Daughter of Charity, Tripoli in Syria, 1o March 1882," Bulletin de l'Oeuvre des Ecoles d'Orient, July 1882, 334-336.

20 Chantal Verdeil, "La classe 'sous le chêne' et le pensionnat: Les écoles missionnaires en Syrie (186o-1914) entre impérialisme et désir d'éducation," Outre-Mers: Revue d'histoire 334-335 (June 2007): 197-222.

21 Jérôme Bocquet, Missionnaires français en terre d'islam, Damas 1860-1914 (Paris: Les Indes savantes, 2005).
} 
obtain employment. So the Christian Brothers of Bethlehem were able to mobilize the town's notables, even "dissidents" -in other words Greek Orthodox - to the benefit of poorer children, often from Catholic backgrounds. This is what Brother Onésime explained to his superiors in order to justify the links that the mission maintained with these non-Catholic communities (who were therefore "suspect" in the eyes of his superiors):

Another consideration which is not of the same order but is of value in that it relates to charity: in general, our Catholics are poor and, since the dissidents belong to more influential families, and quickly obtain a situation, they take great pleasure in responding to the requests of their educators in favour of young Catholics in search of a humble position ... I can cite thousands of examples of this. ${ }^{22}$

Here, the missionary schools redistributed money and other social resources from the wealthier communities towards the poorer, and the monks established and supervised forms of solidarity between pupils from different backgrounds. Their role was very similar to that of the charitable congregations in Europe, such as the Daughters of Charity in Paris, which approached high society women to come to the aid of the poor in their care. ${ }^{23}$ More generally, local believers provided a source of funding or gave material aid to the missionaries and their charitable works. For the Jesuit mission in Syria, the sources mention - without further detail—donations in kind and in particular land for rent. They also mention Nicolas Comati, from whom the Jesuits rented a house to house orphans after the 186o massacre, as a "great benefactor of Fr. Fiorovich". 24

In admittedly very exceptional circumstances, the Ottoman state contributed to the funding of missionary activity. After the events of 1860, the Catholic congregations - some of whom had suffered heavily from the violence and

22 "Admission of dissidents into our schools," notes by Brother Onésime, visitor, Bethlehem, August 11, 1910, cited by Karène Summerer-Sanchez, "Action sanitaire et éducative en Palestine des missionnaires catholiques et anglicans," in Missions chrétiennes en terre d'Islam, Moyen-Orient, Afrique du Nord (XVII ${ }^{e}-X X^{e}$ siècles), anthologie de textes missionnaires, ed. Chantal Verdeil (Turnhout: Brepols, 2013), 231-282.

23 Sarah A. Curtis, "Filles de la Charité et assistance locale, l' exemple de la paroisse SaintMédard à Paris au XIxe siècle," in Des Filles de la Charité aux Soeurs de Saint-Vincent de Paul, quatre siècle de Cornettes, ed. Matthieu Bréjon de Lavergnée (Paris: Honoré Champion, 2016), 405-421.

Louis Jalabert, Jésuites au Proche-Orient (Beirut: Dar el-Machreq, 1987), 6o-61. 
destruction-received substantial compensation: it amounted in all to 202,000 francs in compensation for the "blood spilt" and "damage" suffered in Zahlé. ${ }^{25}$ This sum, paid in two instalments, 123,000 francs in October $1862,{ }^{26}$ and the rest at the beginning of 1863 , was twice as large as the amount allocated by the relief committees funded by the OEuvre des Écoles d'Orient (Society of Eastern Schools). ${ }^{27}$ While this compensation was partly directed to charitable works, in particular for orphans, it provided the opportunity for exceptional investments that the mission's ordinary funds alone would not have financed: the purchase of new buildings, the refurbishment and extension of residences.

These local resources were supplemented by revenues from outside, from France, Europe, or the United States. This was the case for Beirut's Syrian Protestant College, which also obtained part of its funding from the school fees paid by pupils. Otherwise, this funding came from American foundations and private donors, most of whom were members of the Board of Trustees, honoured by the institution through the names assigned to its buildings. William E. Dodge (1805-1883), one of the first of these donors, had made his fortune in the railways, timber, copper mining, and real estate, and partly controlled the New York Stock Exchange. ${ }^{28}$ Between them, the sources provide a clue to the family ties that made the institution a family affair: so the chapel built by the Syrian Protestant College in 1891 was attributable to the generosity of Elbert B. Monroe, brother-in-law of Frederick Marquand who had himself financed the construction of a building 10 years earlier. ${ }^{29}$

For its part, Saint-Joseph University was the beneficiary of substantial French public funds, which financed the medical faculty it opened in 1883 . At the end of the 19th century, the subsidy paid by the government was in the region of 100,000 francs, ${ }^{30}$ for a faculty which at the time had slightly over a hundred students. ${ }^{31}$ This colossal commitment and the French government's support for myriad missionary activities has prompted some to highlight, quite

25 Archives libanaises de la Compagnie de Jésus (ALSI), 8A6, Letter from Fr. Monnot to Fr. Serre, 1876 .

26 Archives romaines de la Compagnie de Jésus (ARSI), Syr 1004, II, 18, Letter from Fr. Canuti to Fr. Beckx, Beirut, October 23, 1862.

27 ARSI, Syr, 1004, 25, Letter from Fr. Canuti to Fr. Beckx, Beirut, October 16, 1863.

28 Alexandra Kobiljski, "Un modèle américain? Les collèges protestants de Beyrouth et Kyoto, 186o-1975," Monde(s) 6 (2014): 187.

29 Stephen B.L. Penrose jr, That They May Have Life (Beirut: American University of Beirut, 1970), 55 .

30 ARSI, Syr 1006, v, 20, letter from Fr. Edde to Father Superior, Beirut, January 27, 1896.

31 Archives françaises de la Compagnie de Jésus (AFSI), Coll Prat, T. 27, information on the Beirut Faculty given confidentially to the Father Provincial by Fr. Cattin (1895). 
correctly, the "immaterial imperialism of language" 32 promoted by the France of the Third Republic. When assigned to each congregation's budget, however, these sums were not so substantial: in order to maintain and develop their activities, the missionaries also relied — as we have seen-on the support of the local populations. They also called on private charity, both in Europe and the USA.

Several works of French historiography on the missions have focused on the missionary charities, such as the charity of the Propagation of the Faith which, from its foundation in the early 1820 , collected considerable sums for all the overseas Catholic missions. ${ }^{33}$ In 1856, just after the Crimean War, a new organization was founded, the OEuvre des Écoles d'Orient (Society of Eastern Schools) which collected funds specifically intended for the missions and for the Churches established in the Orient. In each case, the principle was the same: the charities published letters from the missionaries, whose stories encouraged the faithful to donate. Modest while these donations might be, they were also very numerous, and ultimately generated colossal amounts. From the 1840 os onwards, the revenues of the charity of the Propagation of the Faith underwent very rapid growth, rising from 306,717.42 francs in $183^{1}$ to 4,702,227.21 francs thirty years later. They passed the 5 million threshold in $1864{ }^{34}$ For the Near East, the intercommunal violence that engulfed Mount Lebanon then Damascus, stimulated donations: in November 1861, the OEuvre des Écoles d'Orient collected more than 2 million francs for the Oriental Christians. ${ }^{35}$ Its ordinary budget was significantly smaller, but every year the Catholic missionary organizations and the Catholic churches of the East received subsidies from it.

It would be a mistake to believe that these sums of money came to the missionary organizations without any effort on their part. On the contrary, the Catholic missionaries were skilled in implementing strategies for collecting money, as the example of the Jesuit mission in Syria shows spectacularly.

32 Cabanel, Une France en Méditerranée, 9-28; Thobie, Les intérêts culturels français dans l'Empire ottoman finissant.

33 Richard Drevet, "L' oeuvre de la Propagation de la Foi et la propaganda missionnaires au XIXe siècle," in Une appropriation du monde: Mission et Missions, XIXème-XXème siècles, ed. Claude Prudhomme (Paris: Publisud, 2004), 23-43.

Archivio Storico di Propaganda Fide (APF), fasc. no. 24, April 1831; vol. 32, 186o, 153-200; vol. 37, 1865, 163-208.

35 "Aux membres de l'CEuvre des Ecoles d'Orient," Bulletin de l'Oeuvre des Ecoles d'Orient no. 13, November 1861, 1-6. 
The letters published by the "missionary societies", the Association for the Propagation of the Faith, and the CEuvre des écoles d'Orient, were written specifically for this purpose, or more precisely were inspired by letters from missionaries that were usually rewritten for the readers of the Bulletins of these societies: their purpose was to thank the donors, to report on the activities of the missionaries, their progress (in this case, support for the Christians of the Eastern Catholic Churches, more rarely conversions), and to solicit donations: for this reason, most of the letters mention the needs of the different missionary charities (large numbers of pupils and patients, the poverty of the population ...). In the 2oth century, many congregations published postcards to illustrate their activities and solicit donations.

For example, this photograph (Figure 1.1) shows a Capuchin missionary distributing food. The caption on the verso says: "The offerings for the Syria Missions are received at the Procure of the Missions to the Levant 14, rue des Tourelles, Lyon (St Just)."36

In the Jesuit mission in Syria, one priest had the specific task of collecting funds. This was the "procurer". Two monks distinguished themselves particularly in this role, Fr. Amédée of Damas (1821-1903), procurer between 1859 and 1869 (then founder of the Armenia mission in 1880), and Fr. Louis Jalabert (1877-1943), unofficial representative of the Catholic missions to the French government during the period of the mandate. The son of Louis XVIII's Minister of Foreign Affairs, brought up alongside the Count of Chambord (heir to the throne of France), Fr. de Damas placed his connections at the service of the Society and its missions. During several journeys in the 186os, he solicited the generosity of the European aristocracy. In 1862, he travelled to Paderborn, to Cologne and then to Vienna, where he met the Emperor, his mother the Archduchess Sophie, the Cardinal of Vienna, and the papal Nuncio before delivering the Lent sermon in the Church of the Teutonic Knights. The Society of the Immaculate Conception of Vienna offered to send scholarships to the seminary-college that the Jesuits ran in Mount Lebanon, while the Committee of the Holy Sepulchre of the Cities of the Rhine (Paderborn, Cologne) and of Bavaria (Munich) sent donations several times: 3,00o thalers (12,00o francs) in $1861,20,000$ francs in $1862 .{ }^{37}$

$36 \quad$ Postcard, Collection Gélébart.

37 AFsI, Coll Prat, vol. 9, letter from Fr. Bourquenoud to Fr. Gautrelet, Paderborn (May 19, 1861), 993-994. 


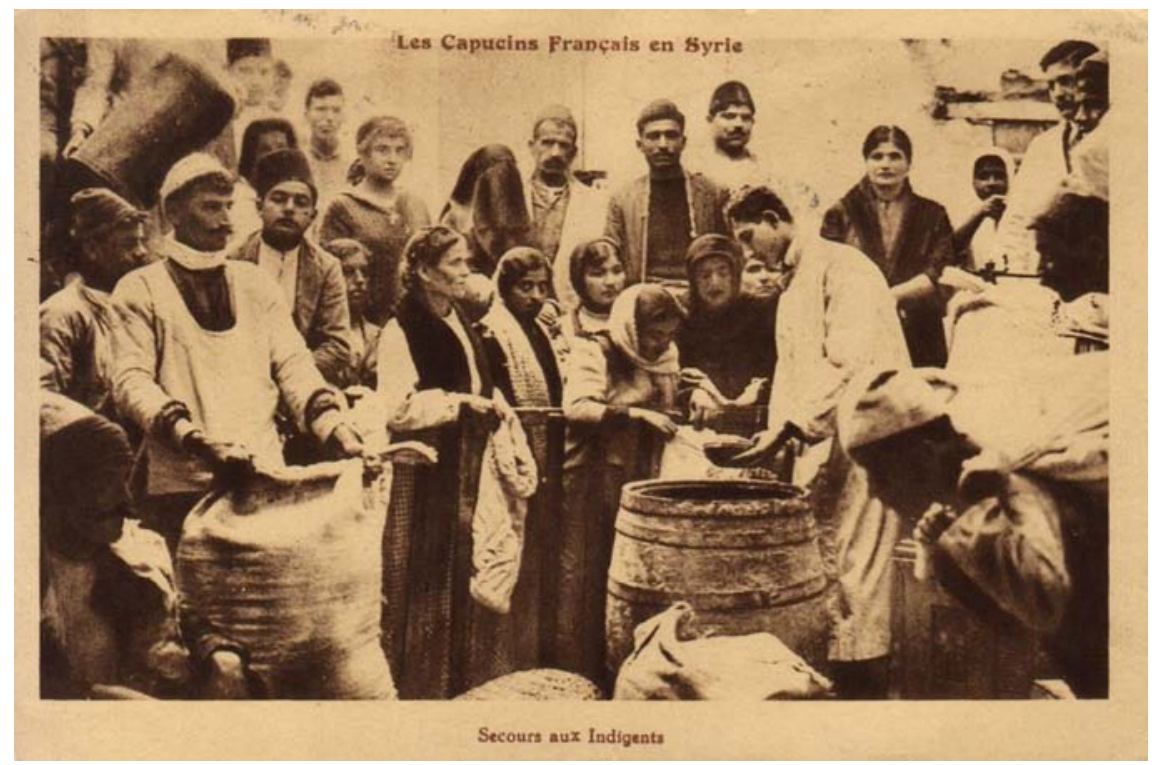

FIGURE 1.1 Postcard, Collection Gélébart, private collection.

Despite his name, which suggests an association with the Legitimist movement that in France supported the former Bourbon dynasty, Fr. de Damas approached the French Imperial government which, at the time (before 186o), was not providing financial support for the mission. Here again, he obtained scholarships for the Jesuit students: this connection began a policy of collaboration which reached its apogee in the joint creation of the Faculty of Medicine at Saint-Joseph University which, as we have seen, was almost entirely funded by the French government of the Third Republic.

In order to maintain this support, the Jesuits had to sustain such connections, which could be threatened by political change. In this respect, the role of Fr. Lucien Cattin (1851-1929), rector of Saint-Joseph and Chancellor of the Faculty of Medicine, was essential at the turn of the century and following the rise to power of the Left-Wing Block, with its highly anticlerical programme. His letters describe him in Paris, moving from ministerial offices to dinners in town, in search of people able to introduce him to ministers or to support his cause, at a time when the election of numerous anticlerical MPs was threatening the French government's support for the Catholic missions. Thanks to his contacts and connections, Fr. Cattin was able to save the most important things: the college scholarships were discontinued in 1906, but the subsidy for the Faculty of Medicine was maintained and even increased.

Other methods of collecting money could be used: for example, the construction of Beirut's Saint-Joseph University was largely financed by funds col- 
lected from ... American Catholics by Fathers Monnot (1831-1898) and Pailloux (1814-1887), respectively superior of the mission and architect of the building. In 1871, the two men travelled to England, then to the United States, where they spent almost three years collecting the money for the construction of the college. They returned to Beirut in the autumn of 1874 , when work began: the University opened its doors a year later. ${ }^{38}$

\section{5}

\section{Conclusion}

Catholic and Protestant missionaries in the Levant were deeply involved in charitable activities. This simple fact justifies considering their action in the light of that of NGOS. Here I aim to highlight the financial dimension of this charitable work.

The financing of the missions, and in particular their most charitable activities relied on the use of various fundraising techniques that can be analysed very well using the vocabulary employed by modern fundraisers: appeal to "small" donors, verbally and in writing, sermons followed by collections, and the letters in the Bulletins, approaches to "sponsors" although this was not a term used at the time, who could be political or society figures or organizations, requests for subsidies from public actors, as was the case for the Jesuit mission in Syria with the governments of the Second Empire then of the Third Republic.

There was nothing "spontaneous" or improvised about this, as evidenced by the care with which the letters were written or rewritten for the missionary bulletins, the appointment in certain religious congregations of one person particularly responsible for fundraising, the capacity to maintain relations with generous sponsors or public institutions.

The examination of missionary resources highlights different financial circuits, some of them spanning seas and oceans, from Europe or the United States to the Middle East, others with a local dimension. At the centre, the missionaries orchestrated the flow of funds at these different levels: their charitable works were the outcome both of the investment of sums collected overseas and of the redistribution of wealth within local societies.

Finally, these financial circuits highlight their ability to mobilize their social capital derived from their individual, political, or religious networks. They might rely on family support (as we have seen for the American Mission in Beirut), on personal relationships with politicians and political officials (for

38 Jullien sj, La nouvelle mission de la Compagnie de Jésus en Syrie, 47-50. 
instance for the Jesuits) and on a sectarian network (Catholic for the Jesuits who found support from American Catholics to finance their new College). The missionaries' knowledge of local societies and their experience of the local field are often highlighted to allow comparisons with humanitarian organizations. But their skills in raising funds were also crucial for the improvement of their activities, as they are for NGO s involved in humanitarian actions today.

\section{Bibliography}

Archives françaises de la Compagnie de Jésus, AFSI. Coll Prat, vol. 9, letter from Fr. Bourquenoud to Fr. Gautrelet, Paderborn (May 19, 1861): 993-994.

Archives françaises de la Compagnie de Jésus, AFsı. Coll Prat, T. 27, information on the Beirut Faculty given confidentially to the Father Provincial by Fr. Cattin (1895).

Archives libanaises de la Compagnie de Jésus, ALSI. 8A6, letter from Fr. Monnot to Fr. Serre (1876).

Archives romaines de la Compagnie de Jésus, ARSI. Syr 1004, II, 18, letter from Fr. Canuti to Fr. Beckx, Beirut (October 23, 1862).

Archives romaines de la Compagnie de Jésus, ARSI. Syr, 1004, 25, letter from Fr. Canuti to Fr. Beckx, Beirut (October 16, 1863).

Archives romaines de la Compagnie de Jésus, ARSI. Syr 1006, v, 20, letter from Fr. Edde to Father Superior, Beirut (January 27, 1896).

Archivio Storico di Propaganda Fide (APF). Fasc. no. 24, April 1831; vol. 32, 186o, 153-200; vol. 37, 1865, 163-208.

Audet-Gosselin, Louis, and Marie Nathalie LeBlanc. Faith and Charity: Religion and Humanitarian Assistance in West Africa. London: Pluto Press, 2016.

Barnett, Michael, and Janice Gross Stein. "Introduction: The Secularization and Sanctification of Humanitarianism." In Sacred Aid: Faith and Humanitarianism, edited by Michael Barnett and Janice Gross Stein, 3-36. Oxford: Oxford University Press, 2012.

Baron, Beth. "Orphans and Abandoned Children in Modern Egypt." In Interpreting Welfare and Relief in the Middle East, edited by Nefissa Naguib and Inger Marie Okkenhaug, 13-34. Leiden, Boston: Brill, 2008.

Baron, Beth. "Liberated Bodies and Saved Souls: Freed African Slave Girls and Missionaries in Egypt." In African Communities in Asia and the Mediterranean: Between Integration and Conflict, edited by Ehud R. Toledano, 215-235. Halle: Max Plank Institute, 2011.

Ben-Néfissa, Sarah. "ONG, gouvernance et développement dans le monde arabe." Gestion des Transformations Sociales MOsT, Document de discussion, no. 46 (2000). http://www.unesco.org/most/nefissa.html. 
Bocquet, Jérôme. Missionnaires français en terre d'islam, Damas 1860-1914. Paris: Les Indes savantes, 2005 .

Bozarslan, Hamit. Sociologie politique du Moyen-Orient. Paris: La Découverte, 2011.

Bulletin de l'Oeuvre des Ecoles d'Orient, no. 13. "Aux membres de l' CEuvre des Ecoles d'Orient." November 1861, 1-6.

Bulletin de l'Oeuvre des Ecoles d'Orient. "Letter from Sister Ramel, Daughter of Charity, Tripoli in Syria, 10 March 1882." July 1882, 334-336.

Bulletin de l'Oeuvre des Ecoles d'Orient. "Letter from Sister Meyniel, Daughter of Charity." November 1883, 167-172.

Bulletin de l'Oeuvre des Ecoles d'Orient. "Letter from Sister Marie, Daughter of Charity, Superior of the Saint Joseph house in Damas." January 1887, 15-17.

Cabanel, Patrick, ed. Une France en Méditerranée. Paris: Créaphis, 2006.

Collection Gélébart, private collection. Postcard.

Cosnier, L. Le Bon-Pasteur d'Angers en Égypte: L'œuvre des Écoles d'Orient. Angers: Librairie Lachèse et Dolbeau, 1882 .

Curtis, Sarah A. "Filles de la Charité et assistance locale, l' exemple de la paroisse SaintMédard à Paris au XIXe siècle." In Des Filles de la Charité aux Soeurs de Saint-Vincent de Paul, quatre siècle de Cornettes, edited by Matthieu Bréjon de Lavergnée, 405-421. Paris: Honoré Champion, 2016.

Drevet, Richard. "L'oeuvre de la Propagation de la Foi et la propagande missionnaire au XIXe siècle." In Une appropriation du monde: Mission et Missions, XIXème-XXème siècles, edited by Claude Prudhomme, 23-43. Paris: Publisud, 2004.

Felkay, Chrisitan. "Filles de la Charité et bureaux de bienfaisance parisiens (1796-186o)." In Des Filles de la Charité aux Sours de Saint-Vincent de Paul, quatre siècles de cornettes, edited by Matthieu Bréjon de Lavergnée, 391-404. Paris: Honoré Champion, 2016.

Fredj, Claire. "Une présence hospitalière en territoire colonial, les filles de la Charité en Algérie (1842-1962)." In Des Filles de la Charité aux Sours de Saint-Vincent de Paul, quatre siècles de cornettes, edited by Matthieu Bréjon de Lavergnée, 446-474. Paris: Honoré Champion, 2016.

Jalabert, Louis. Jésuites au Proche-Orient. Beirut: Dar el-Machreq, 1987.

Jullien, Michel sj. La nouvelle mission de la Compagnie de Jésus en Syrie, 1831-1895. Tours: Imprimerie Mame et Fils, 1899.

Kobiljski, Alexandra. "Un modèle américain? Les collèges protestants de Beyrouth et Kyoto, 186o-1975." Monde(s) 6 (2014): 171-193.

Penrose, Stephen B.L.jr. That They May Have Life. Beirut: American University of Beirut, 1970.

Prudhomme, Claude. “Quand triomphe la mission: autopsie d' un succès.” In Une appropriation du monde: Mission et missions, XIXème-XXème siècles, edited by Claude Prudhomme, 5-15. Paris: Publisud, 2004. 
Rodogno, Davide. Against Massacre, Humanitarian Interventions in the Ottoman Empire, 1815-1914: The Emergence of a European Concept and International Practice. Princeton: Princeton University Press, 2012.

Summerer-Sanchez, Karène. "Action sanitaire et éducative en Palestine des missionnaires catholiques et Anglicans." In Missions chrétiennes en terre d'Islam, MoyenOrient, Afrique du Nord (XVII $I_{-X X}^{e}$ siècles), anthologie de textes missionnaires, edited by Chantal Verdeil, 231-282. Turnhout: Brepols, 2013.

Thobie, Jacques. Les intérêts culturels français dans l'Empire ottoman finissant. Leuven: Peeters, 2008.

Turiano, Annalaura. "De la pastorale migratoire à l' enseignement technique, missionnaires italiens en Égypte: Les salésiens et l'enseignement professionnel (189o1970)." PhD diss., Aix-Marseille Université, Aix-en-Provence, 2016.

Turiano, Annalaura. "État, réformistes et philanthropes: Les enjeux de l' enseignement professionnel en Égypte au tournant du Xxe siècle." Histoire de l'Éducation 148 (2018): 41-70.

Verdeil, Chantal. “Travailler à la renaissance de l' Orient chrétien: Les missions latines en Syrie (1830-1945)." Proche-Orient Chrétien 51, nos. 3-4 (2001): 267-316.

Verdeil, Chantal, ed. Missions chrétiennes en terre d'Islam, Moyen-Orient, Afrique du Nord (XVII ${ }^{e}-X X^{e}$ siècles), anthologie de textes missionnaires. Turnhout: Brepols, 2013. Verdeil, Chantal. La missionjésuite du Mont-Liban et de Syrie (1830-1864). Paris: Les Indes Savantes, 2011.

Verdeil, Chantal. "La classe 'sous le chêne' et le pensionnat: les écoles missionnaires en Syrie (186o-1914) entre impérialisme et désir d'éducation." Outre-Mers: Revue d'histoire, 334-335 (June 2007): 197-222. 
- 978-90-04-43453- 0

Downloaded from Brill.com04/26/2023 01:14:44PM via free access 
PART 2

Advocacy 
- 978-90-04-43453- 0

Downloaded from Brill.com04/26/2023 01:14:44PM via free access 


\title{
Liberated Bodies and Saved Souls: Freed African Slave Girls and Missionaries in Egypt
}

\author{
Beth Baron
}

In early March 1887 twelve freed slave girls arrived at the Ezbekiah Boarding School run by American Presbyterian missionaries with fifty pounds and forty yards of calico for dresses. ${ }^{1}$ They had been sent by Sir Evelyn Baring (Lord Cromer), the British agent and consul-general in Egypt from 1883 to 1907, from the Cairo Home for Freed Female Slaves, where they had been temporarily lodged. ${ }^{2}$ The dozen girls had been intercepted by British boats on the Red Sea or Egyptian police in caravans coming over land into Egypt ten years after the slave trade had been officially banned into and through the country and a few years before slavery itself became illegal. Their paths into slavery varied; their path out brought the dozen young girls together.

The enslaved in Egypt and the Islamic Middle East were mostly illiterate and left few memoirs. The lack of slave narratives and "silence of slaves" have led to an absence of voices, faces, and names of slaves from historical accounts. Scholars have recently begun to rectify this omission through innovative methodologies and literary strategies. Ehud Toledano argues, "by exploring the available options, the dilemma at hand, and the choice made by the enslaved, we can see agency and resistance emerge out of misery and powerlessness", as he focuses on the relationship that bound the enslaved and slavers. Eve Troutt Powell analyzes memoirs that have come to light, critically reading texts and raising issues about voice and memory. ${ }^{3}$ The search for new sources-visual

1 This article has been published first in African Communities in Asia and the Mediterranean: Identities between Integration and Conflict, ed. Ehud R. Toledano (Trenton, NJ: Africa World Press, 2011), 215-235.

2 Presbyterian Historical Society (PHS), Anna Thompson Papers, RG 58, box 1, folder 4, Notebook: Red Letter Days: 57, 59. The event is noted as occurring on March 1 and March 7 .

3 Ehud R. Toledano, As If Silent and Absent: Bonds of Enslavement in the Islamic Middle East (New Haven: Yale University Press, 2007); idem, Slavery and Abolition in the Ottoman Middle East (Seattle: University of Washington Press, 1998); John Hunwick and Eve Troutt Powell, The African Diaspora in the Mediterranean Lands of Islam (Princeton: Markus Wiener Publishers, 2002); Y. Hakan Erdem, Slavery in the Ottoman Empire and Its Demise, 1800-1909 (New York: St Martin's Press, 1996). 
and literary-continues alongside efforts to push theoretical understandings of slavery in the Middle East.

American missionaries were prodigious writers who kept careful records. Through years of study and practice, they mastered Arabic, and their long residences in the field (sometimes for decades) running a network of educational, medical, and welfare institutions gave them impressive knowledge of their host country. They also came with their own religious and racial baggage, which must be carefully unpacked when examining the records they left of encounters with freed slaves. These records can be read critically to get at the lives and choices of the dozen African girls who landed on their doorsteps. The story of these girls provides a look at the paths into and out of slavery, drawing attention to the youth of most of those caught in the net of the slave traders and destined for service in the Ottoman Empire.

Scholars have debated the demise of slavery in Egypt and the fate of freed slaves. The question of the demise of slavery, and whether it ended with a whimper or a bang from internal or external pressures, is tied to views of the importance of slavery in Egyptian society. Gabriel Baer tends to discredit the efficacy of bans on the slave trade enacted from the 185 os by OttomanEgyptian governors and credits the British for effectively ending the trade; he finds that the presence of guilds and absence of a free labour market hampered the absorption of freed slaves into the Egyptian society and economy. Judith Tucker sees slavery fading out more naturally. "Never of signal importance in the country, the institution slowly crumbled", as over the course of the century the significance of female slaves, who were the majority, became "ever more symbolic". Slavery "swiftly became an anachronism" and was abolished with ease. "Once the supply was cut off, and slaves could seek manumission freely, the institution in Egypt died a painless death". Tucker claims that manumitted slave women were easily assimilated "into the very classes that had formerly possessed them", with race and an earlier slave status holding no stigma. ${ }^{5}$

Other scholars occupy a middle ground. Liat Kozma, focusing on legal and police records, has sketched the abolition of the slave trade through numerous bans "as a long process of readjustment" in which the Ottoman-Egyptian legal system moved from the Islamic sanction of slavery to the "suppression of the slave trade as unjust and inhumane". In the process, "[s]laves came to be seen

4 Gabriel Baer, "Slavery in Nineteenth Century Egypt," Journal of African History 8, no. 3 (1967): 417-441; reprinted as "Slavery and Its Abolition," in Studies in the Social History of Modern Egypt (Chicago: University of Chicago Press, 1969), chap. 10.

5 Judith E. Tucker, Women in Nineteenth-Century Egypt (Cambridge: Cambridge University Press, 1985), 191-192. 
more as persons and less as property". ${ }^{6}$ Powell, looking at literary accounts and the press, sees slavery as of signal importance in Egypt's complicated colonial relationship to the Sudan. She notes the difficulty of letting go of an institution that was central to conceptions of family and intimacy, and her examination of a famous slave trading trial in 1894, which implicated leading notables, highlights this. ${ }^{7}$ For Toledano, Powell, and Kozma, race mattered, and freed slaves, most of whom were of African origins, struggled with marginality, vulnerability, and limited choices. ${ }^{8}$

In this chapter, I will show that at least in the case of the twelve enslaved African girls, and reasonably also beyond that small group, the end of slavery was neither swift nor painless. Freed slaves' attempts to shape their own lives must be seen in this context.

\section{1 \\ Memories of Home and Capture}

In the period in which the American Presbyterian missionaries established a network of institutions in Egypt, the slave trade spiked, particularly during the cotton boom of the 186os, when Egyptian cotton replaced the American commodity on the market. Slaves were brought in as a result of the wealth flooding the country from cotton profits as well as for agricultural slavery in the south. Most were domestic slaves (concubines and/or servants) in a system that did not reproduce itself and thus needed a constant influx of new slaves. The girls who landed in the Ezbekiah Boarding School ranged in age from eight to fourteen, consistent with Reda Mowafi's observation that the largest proportion of slaves imported into Egypt were under fifteen. Traders preferred younger slaves because they fetched a higher price, needed less food, and were less likely to resist during their transport. Those eleven to fourteen or fifteen were the most expensive, primarily because at that age they were young enough to be

6 Liat Kozma, "Women on the Margins and Legal Reform in Late Nineteenth-Century Egypt, 1850-1882" (PhD diss., New York University, 2006).

7 Eve M. Troutt Powell, A Different Shade of Colonialism: Egypt, Great Britain, and the Mastery of the Sudan (Berkeley: University of California Press, 2003).

8 See also Beth Baron, Egypt as a Woman: Nationalism, Gender, and Politics (Berkeley: University of California Press, 2005), chap. 1; Imad Hilal, Al-Raqiq fi Misr fi al-qarn al-tisa' 'ashar (Cairo: al-Aarabi, 1999); Hilal, "The Anti-Slavery Movement in Egypt in the Nineteenth Century: Between Shari'a and Practice" (paper presented at a workshop on "Race and Slavery Between the Middle East and Africa," Cuny Graduate Center, April 23, 2004); Reda Mowafi, Slavery, Slave Trade, and Abolition Attempts in Egypt and the Sudan, 1820-1882 (Stockholm: Esselte Studium, 1981). 
trained within a family to be a good servant but old enough to start working and engage in sexual activity, even if unwanted. ${ }^{9}$ In any case, the girls taken in by the missionaries were definitely old enough to have memories of family and home.

The origins of the twelve were never precisely recorded. A British abolitionist who visited them in the school and heard them sing some hymns "in their own language" claimed the girls came from "Galla country". ${ }^{10}$ (Today "Galla" is considered a pejorative term for the Oromo, who are mostly found in Ethiopia, formerly called Abyssinia.) But Anna Thompson, an American Presbyterian missionary who worked in Egypt from 1872 to 1932, noted a few years after the girls had come to the school, "there were Nubians among them, Soudanese and Abyssinians". ${ }^{11}$ Later, in an anonymous pamphlet on one of the freed slaves produced in the 193os or so, they are listed as seven Ethiopians and five Sudanese; Abyssinians became Ethiopians, and the Nubians were folded into the Sudanese. ${ }^{12}$ The native tongues that they claimed, and the language in which they spoke to one another are not clear.

One of the girls, named Susan, was from Nubia, according to Thompson:

In her inimitable way, after some weeks, she told how she had been carried away with her family and villagers by the Mahdi and his troops, and how she used to play with the Mahdi's children ... Her singing about the Mahdi and the white "hat owners" (English troops) as she learned it at Khartoum, was always listened to with pleasure and sadness, and she and two others could dance in the very peculiar Soudanese style. ${ }^{13}$

Susan had clear memories of home that came through in her singing and dancing, though the latter was suppressed as she became socialized into proper Christian behavior at the boarding school. The missionary teacher, Adela Brown, reflected on the summer of 1890 when Susan and one or two of the other girls stayed at the school in Cairo, unable to go home to relatives as the Egyptian girls had. Missionaries and government officials made no attempt to return these girls to their native villages, but their longing was apparent. "I heard from

\footnotetext{
9 Mowafi, Slavery, 37.

10 "Egypt," Anti-Slavery Reporter (March-April 1893), 63.

11 Anna Y. Thompson, "Mission Work in Egypt," Women's Missionary Magazine 5, no. 3 (October 1891): 68 .

12 Halima-The Gentle One (Pittsburgh: Women's General Missionary Society, United Presbyterian Church of North American, n.d.), 7 .

13 Thompson, "Mission Work," 68.
} 
them many interesting items about their native land. It was their delight to talk about ther [sic] parents and home and country. They seemed to have vivid pictures in their minds, but whether they were fancy or real I cannot say". ${ }^{14}$ The girls had strong memories of home that they liked to relate, and they listened to one another's stories and songs.

By contrast, another girl, Halima, seemed to remember little, though she was thought to be about eleven years old when she arrived at the boarding school. "Years later when questioned by friends, she could tell little of her early life," recorded her pamphleteer. She may have remembered little or may have found the memories too painful and chose to bury them deep inside. She did remember her village home in the mountains of Ethiopia in the western part of the country; the village name; and a war, in the midst of which she and some other girls were snatched while at play near the village. She did not know by what route she had been brought to Egypt, so the pamphleteer had her brought her up the Nile on a boat, rescued, and put on a train for Cairo. (The "Galla girls" had been intercepted by a British ship on the Red Sea-thus earning the name "Red Sea waifs" - and disembarked at Port Suez, where they were transferred to Cairo. Some of these girls ended up at the Ezbekiah boarding school.) Halima was a child when she was taken from her family and shipped to Egypt. The pain of that separation stayed with her, as Halima related, "I cried for my mother whenever I was awake, for a year". ${ }^{15}$

Susan seems to have been displaced twice, once with her family from Nubia to Khartoum and once on her own. She remembered being at play with another child, "getting gum from a tree", when a man on horseback carried her off. She was then passed from one person to another until she was captured by the police in Egypt. ${ }^{16}$ Her route into Egypt could have been a desert caravan led by Bedouins, who smuggled slaves to Asyut to avert bans on the slave trade. The Egyptian police force had turned from protecting owners' property rights and returning runaway slaves to enforcing the bans on the slave trade, mirroring a shift in the Ottoman Empire, where government officials had come to side with the enslaved more than the enslavers. ${ }^{17}$

The girls' memories of their homes and families come through the filter of missionary writings. At times the girls seemed eager to speak to Americans about their pasts; at other times they withheld their stories and sought to

14 A.A. Brown, "Susan Ameen," Cairo, November 1891 in Women's Missionary Magazine 5, no. 6 (January 1892): 166-167.

15 Halima, 3-4, 7; "Egypt," Anti-Slavery Reporter (March-April 1893), 63.

16 Thompson, "Mission Work," 68.

17 Kozma, "Women on the Margins," chap. 3; Toledano, Silent and Absent, chap. 3. 
repress painful memories. The missionaries passed on only tidbits, weaning out pieces of the story and dismissing parts as childish fantasies.

Both the slave traders and missionaries sought to redefine the religious identities of the girls. The missionaries claimed that the girls were given "Mohammedan names" by the slave traders. By making this claim, the missionaries pointed to the recent and coercive nature of their conversion to Islam. At some point during the transport of their human cargo, slavers converted the enslaved to Islam in preparation for their sale in Egypt and often gave them new names to signal their new religious identity. ${ }^{18}$ By Islamic law, the enslaved were meant to be non-Muslims captured in war, but most were captured in raids, not war, and some were already Muslims. The missionaries allowed them to keep their names, whether given by parents or slavers, except in cases of repetition. The smaller of the two Mariseela's became Seela; and the smaller of the two Taroonga's became Susan, to evoke Aswan. ${ }^{19}$ Those named in the sources (like Susan and Halima) have only first names; there are no second or father's names. The erasure of family ties transforms the girls into orphans, which is how they are labeled and treated. Few of the other freed slave girls were named at all, and not naming is also significant. They were blank slates, ready for redemption in life or death.

\section{$2 \quad$ Rescue and Manumission}

Missionaries, British abolitionists, colonial officers, Egyptian government officials, slave traders, and the enslaved were all caught up in a contentious battle over slavery. The lines in this battle were not clearly drawn. Egyptians had mixed views on slavery: those against the practice realized that stripping the Sudan of her population undermined Egyptian colonial ambitions and civilizing mission, ${ }^{20}$ that the slave trade as currently practiced contravened Islamic law, and that wage labour ultimately made more economic sense than slavery. But others profited from the trade, considered the slaves they owned assets that enhanced their prestige, saw slavery itself as civilizing and sanctioned by Islam, and could conceive of no alternative for domestic service. Said, governor

18 John Hunwick, "The Religious Practices of Black Slaves in the Mediterranean Islamic World," in Slavery on the Frontiers of Islam, ed. Paul E. Lovejoy (Princeton: Markus Wiener Publishers, 2004), 149-171.

19 Thompson, "Mission Work," 68.

$20 \quad$ For more on this, see Sara Pursley, "From Civil War to Civilizing Mission: American Military Officers in the Egyptian Service, 1869-1879" (paper presented at a workshop on "Race and Slavery Between the Middle East and Africa," CunY Graduate Center, April 23, 2004). 
of Egypt (1854-1863), had banned the slave trade in 1854; but in the absence of instruments to enforce it, the ban had been generally ineffective in stopping the slave trade, though it began to change the way the legal system conceptualized slaves. ${ }^{21}$

With the end of slavery in America, British abolitionists turned their attention to slave practices in the Ottoman Empire and pushed for stricter treaties. The Anglo-Egyptian convention of 1877 outlawed the import and export of Abyssinian and Sudanese slaves, setting up four manumission bureaus throughout Egypt to supply documents as well as find work for freed slaves and schools for freed children. Banning the slave trade when owning slaves was still legal proved difficult to enforce, especially when traders frequently passed off slaves as family members or as servants. The British, who used anti-slavery sentiments in England to mobilize support for their occupation of Egypt in 1882 and continued colonial presence, were afraid to tackle Islamic law and practices head on and moved slowly in outlawing slavery itself.

The outlawing of the slave trade when the demand for domestic slaves remained made life for smuggled slaves more precarious, as traders took detours and risks to avert the watchful eyes of agents. Officials plugged one hole only to find slaves brought into Egypt through another route. One such avenue was the importation of slaves by pilgrims returning from Mecca. It was a tempting and lucrative trade, with a high mark-up: in the mid-188os female slaves could be purchased in Mecca for about four pounds and sold in Egypt for thirty. ${ }^{22}$

Officials sought to stop the smuggling of slaves by returning pilgrims after the prohibition of the sale of slaves from family to family had gone into effect. Lieutenant-Colonel Schaefer, Director of the Slave Department, sent instructions to the commander at Port Suez in 1886. All pilgrims arriving at Suez, where most either disembarked from vessels or continued through the canal, were to be checked. Newly brought slaves without manumission papers were to be taken from their masters and sent to the Cairo Home for Freed Women Slaves established the previous year; newly brought slaves with manumission papers were to be given a choice whether they wanted to stay with their masters or not (some may have been married to their masters.) "If they are under 14 years," he instructed, "it is better to send them to Cairo." The guidelines for pilgrims traveling by ship were slightly different: "If bought recently and not over 12 years of

\footnotetext{
21 Kozma, "Women at the Margins," chap. 3.

22 E. Crewe, "The Slave Trade in Egypt," Cairo, April 9, 1886 in Anti-Slavery Reporter (MayJune 1886), 61.
} 
age, they are to be brought on shore and sent to Cairo". ${ }^{23}$ Schaefer also instructed the commander at Suez to keep a record of "all negresses or Abyssinians coming in", showing their names, masters if recently purchased or simply traveling, and what was done with them.

Schaefer wrote Baring, "I can assure you that not a single colored person has been allowed to be passed without our getting satisfactory explanations about her position". ${ }^{24}$ Note that he writes "her position", acknowledging that most of the "black or Abyssinian, male and female" who came before government officials were girls or women. Some 119 persons were checked at the police office, and forty-one were found to have been purchased in Jidda. Five or possibly seven had no manumission papers and were taken from their masters and sent to the Home for Freed Slaves in Cairo. Those sent to the Home included a Halima, who was owned by Mustapha al-Minyawr, and a Trongue, owned by Sitt Agouche, showing both male and female ownership. Both Halima and Trongue were listed as Sudanese but no ages were given. ${ }^{25}$ These girls may have been those of the same name who later landed in the missionary school, though there is some discrepancy on origin, since the Halima previously mentioned was Abyssinian.

By whatever route they had come into Egypt, both the Halima and Susan who were later raised and schooled by the missionaries had first been sent to the Home for Freed Women Slaves in Cairo. That home had been opened in January 1885 as the product of a joint effort by a committee in London associated with the British and Foreign Anti-Slavery Society (BFASs), which raised funds through subscriptions for the refuge, and a second committee in Cairo, presided over by Baring, which dealt with the logistics. Abolitionists argued that freed male slaves could find ready employment (indeed many ended up in the army) but that freed female slaves would turn to a life of vice and prostitution to survive. This assumption stemmed from a belief that Africans were prone to sexual excess and crime unless properly supervised. The lack of such a home was thought to have impeded the emancipation of slaves and enforcement of the convention of 1877 . Toward that end, Sarah Amos, a feminist, activist, and abolitionist, was one of the main advocates and organizers of the

23 Rhodes House Library, British and Foreign Anti-Slavery Society, S22, G25, Africa, No. 4 (1887), Correspondence Respecting Slavery in Egypt, Enclosure 2 in No. 1, LieutenantColonel Schaefer to Captain Crawford, Commandant, Suez, October 25, 1886, 4.

24 Ibid., Enclosure 1 in No. 1, Schaefer to Sir E. Baring, Cairo, December 16, 1886, 3.

25 Ibid., Enclosure 3 in No. 1, Schaefer, "Etat Nominal des Esclaves importes pendant le Saison du Pelerinage de 1886," 5 . The list includes question marks next to two names: Halima and Sabah. 
Home, getting it started in the neighbourhood of Faggala and setting up Mrs. Crewe, an Englishwoman who spoke fluent Arabic, as matron. ${ }^{26}$ Crewe's fluency in Arabic would have helped in communication with those slaves who had been resident in Egypt for some time but not the newly enslaved, fresh from Africa.

The Home for Freed Slaves in Cairo acted as a refuge, staging area, and referral agency, and was part of Baring's agenda to turn freed slaves into a pool of waged female labourers or domestic servants. The newly freed slaves first had to be outfitted. Accompanied by a veteran from the Home, they purchased materials in town and returned to the home for sewing instruction, "for strange as it may seem, many of the black girls absolutely do not know how to use a needle", reported the secretary to the Cairo Committee for the Freed Slaves' Home. In this way, in 1886 alone over 6 oo dresses plus other garments were cut. Once outfitted, many of the freed slaves did not stay long. Mrs Crewe helped place them in homes as domestic servants, and they were quickly snatched up, for demand for such servants exceeded supply. Initial reports suggest that the freed slaves were placed with Christian Syrians and Copts, but subsequent ones show that most were placed "in English families, others in French or Italian, and a few in native families of well-known respectability". Turn-around time was sometimes as fast as a few days. ${ }^{27}$ In short, the English were eager to turn slaves into paid domestic servants and became the first beneficiaries of this policy.

When Colonel Scott-Moncrieff, son-in-law of the chairman of the BFAss and a Cairo committee member, visited the Home in October 1885, he found that three of the nine or ten inhabitants of the home were children. Mrs. Crewe, who lived in the Home with her husband and children, claimed she could easily get these girls employment but preferred to train them herself to be good servants. ${ }^{28}$ The following year, sixteen Abyssinian girls—-all young, and some quite little girls", entered the home together, having been intercepted from pilgrims returning from Mecca. None of the girls spoke Arabic, which was taken as a sign that they had been recently and illegally enslaved. According to E. Crewe, the children had been transported by two slave traders: six girls

26 For background on the Home for Freed Slave Women, see the Anti-Slavery Reporter (January 1885), 259; (August 1885), 449-45o; (May-June 1886), 57-58; Diane Robinson-Dunne, The Harem, Slavery and British Imperial Culture: Anglo-Muslim Relations in the Late Nineteenth Century (Manchester: Manchester University Press, 20o6), 84-92.

27 M.S.P. Du Port, "Report of the Cairo Committee for the Year 1886," in Anti-Slavery Reporter (March-April 1887), 69.

28 C. Scott-Moncrieff, letter, Cairo, October 6, 1885 in Anti-Slavery Reporter (December 1885), 595 . 
(and one boy) by Ali Pasha Wahba and ten girls (one boy, and two eunuchs) by the head of the Egyptian pilgrim caravan. In the subsequent six months, two of the new sixteen children were "sent out to service", one was married, and thirteen remained at the Home. Of those thirteen, the seven youngest went to Miss Whately's Mission School, which had been set up by the British missionary for poor children. ${ }^{29}$ The annual report for the Home for 1886 noted that nearly all the Abyssinian girls were "in service, some of them earning over L 1 per month". Six of the youngest had learned to read Arabic, and it was hoped that some might become monitors or teachers in Miss Whately's School. ${ }^{30}$

The youngest of these children, along with others, were included in the total number of children in the Home for 1886: "There are at present about twelve young children, from five to twelve years of age, in the HOME, some of whom have been rescued from Slave-dealers who were bringing them to Cairo to sell as Slaves." These girls received domestic training, in a set regime of household work, sewing, and ironing, "until such a time as they can earn their own livelihood". ${ }^{31}$ These twelve were sent to the American missionary boarding school in Cairo. They may have been sent when space became an issue: 225 slaves passed through the home in 1886, with 215 being placed in homes, and an average of fifteen to twenty occupants at any one time. The Home for Freed Women Slaves in Cairo was simply not equipped to care for young girls on a long-term basis; they would have taken up room and cost money to feed, house, and educate. The home was run on a relatively small budget, with some suggesting that it support itself, leading to a plan to utilize the labour of its inmates in laundry work. The small-scale operation was only marginally profitable, and the young girls could not contribute meaningfully to this plan or to their upkeep. ${ }^{32}$

Halima, Susan, and the others may have been sent away for another reason as well. According to the Convention of 1877 , freed slave children were to be educated, and the youngest had gone to Miss Whately's School. But the close association of girls in the Home with the missionary enterprise might have posed problems for Baring, who served as both president of the Home and British consul-general. The Home had to refrain from proselytizing among those who sought shelter, a condition the Cairo committee imposed on the project in

29 C.C. Scott-Moncrieff, "The Treasurer's Report-1886," Anti-Slavery Reporter (May-June 1886), 58; Crewe, "Slave Trade in Egypt," 61.

30 Du Port, "Report," 69; Mary L. Whately, Letters from Egypt to Plain Folks at Home (London: Seeley, Jackson, \& Halliday, 1879), 240-257; Charles C. Starbuck, "Theological and Religious Intelligence," The Andover Review (May 1889): 529.

31 Du Port, "Report," 69.

32 Du Port, "Report," 68-69. 
order to make it acceptable to the Egyptian government, which gave the Home a 250 pound subvention. The question of slavery was controversial enough without adding religious conversion into the mix. Sending the girls to another location removed responsibility from the Home.

\section{Education and Redemption}

American missionaries who arrived in Egypt in the 1850s targeted Cairo and Asyut, a town in Upper Egypt with a large Coptic population thought to be receptive to Protestantism. Asyut was also a major depot in the slave trade and the destination for caravans on the "forty days road" (darb al-arba in) from Darfur. By coincidence, the American Mission School was situated close to the spot where the slave caravans to Asyut came to rest. ${ }^{33}$ Most American missionaries in Egypt came from northern states such as Pennsylvania, Ohio, and Illinois. They had seen battles over slavery split their country and church, giving rise to the United Presbyterian Church of North America (UPCNA), founded in $185^{8}$. The UPCNA had a strong abolitionist platform and opened "freedmen's missions" after the American Civil War. But Americans in Egypt were there to save Egyptian souls, not to free African slaves, and treaded carefully. ${ }^{34}$ Still, when opportunities presented themselves, they intervened, pressuring Copts to free their own slaves, alerting consuls to slave caravans, and giving refuge to rescued slaves. ${ }^{35}$ The missionaries benefited from their interventions. The first Muslim convert was an unnamed freed slave who joined the church in 1866 , and twenty-two of the thirty-nine Muslims who had been baptized by 1883 were freed slaves. This is not surprising, notes Heather Sharkey, for "[i]n many ways, ex-slaves, like orphans, were perfect candidates for conversion, since by definition they lacked families who were apt to drag them back to the Muslim community under threats of death." And disinheritance was not a disincentive either, as they had little property to lose. ${ }^{36}$

33 Muhafazat Asyut, Asyut fi 10 Sanawat (Cairo: Matba'at Nahdat Misr, 1962), 9; George M. La Rue, "The Capture of a Slave Caravan: The Incident at Asyut (Egypt) in 188o," African Economic History 30 (2002): 89.

34 Ahmed E. Elbashir, The United States, Slavery and the Slave Trade in the Nile Valley (Lanham: University Press of America, 1983), 61-66.

35 See, for example, PHS, RG 4O4, box 1, folder 3, Margaret Anna Smith Diary, August 25, 1878; RG 58, box 1, folder 8, Anna Thompson papers, Arabic manumission certificate; La Rue, "Capture of a Slave Caravan," 81-106.

36 Heather J. Sharkey, American Evangelicals in Egypt: Missionary Encounters in an Age of Empire (Princeton: Princeton University Press, 2008), 77. 
Missionary schools had also given shelter to freed slaves before. The Pressly Memorial Institute in Asyut had taken in three Sudanese girls from DarfurKeltuma, Assa, and Fanna - who had been "rescued by the pluck of some Soudaneese boys", according to Margaret McKown, founder of the school. The girls were placed in the boarding school, which gathered girls from area villages to train them in "common school education" and domestic work, and sent them back to their villages to minister to their own communities. At the school, the freed slaves received "the same training as the Egyptian girls" and were baptized three years after their arrival. But mobility for these freed African slave girls was more limited than those for Egyptian students. While the latter became teachers and Bible women, Keltuma and Assa (Fanna died prematurely) became matrons in the school and could be seen in a staff photograph taken in 189o. And although graduates of the school married Egyptian pastors, evangelicals, and teachers, the freed slaves joined a sisterhood of single women. ${ }^{37}$

When Baring approached American missionaries in Cairo to take in the twelve little black girls and train them as they wished, the women missionaries saw an opportunity. "Knowing their need of instruction, and hoping that some day teachers might be educated from their number for central Africa or the far 'upper country,' our mission consented," wrote Thompson. ${ }^{38}$ Evangelicals loathed the alternative: "For want of funds these girl would have been given over to the Roman Catholics, had not the Protestant missionaries consented to take them," reported The Christian, a British periodical. ${ }^{39}$ The readers of The Christian were asked to send in shoes and simple dresses to be forwarded to the freed slaves.

The twelve girls who moved from the Home for Freed Slaves in Faggala to the boarding school in Ezbekiah in March 1887 had not been consulted about their change of home and school. When they arrived at their new abode, they did not take kindly to the new routine and structure. As Thompson explained in her annual report, "Some had been in the home [for Freed Women Slaves] for several months. These came to us much prejudiced against me. Strange stories had been told them of how we would make them work, abuse them, and make them Christians" ${ }^{40}$ In short, the girls had already developed their own inform-

M.J. McKown, “Girls' School Assiout, Egypt," Women's Missionary Magazine vol. 3, no. 11 (June 189o): 281; Earl Elder, Vindicating a Vision: The Story of the American Mission in Egypt, 1854-1954 (Philadelphia: United Presbyterian church of North America, 1958), 81.

38 Thompson, "Mission Work," 68; see also, Thompson's annual report quoted in Halima, 5 .

39 The Christian (June 3, 1887) in Anti-Slavery Reporter (May-June 1887), 91.

40 Thompson's annual report quoted in Halima, 5 . 
ation networks, most likely among the older freed slaves, and did not go quietly. In a letter to the Women's Missionary Magazine, Thompson elaborated on the girls' resistance: "without any knowledge of what their parents' religion was, they were all zealous for the Moslem faith, and the older ones were for a time refractory, because they heard we were going to baptize them". ${ }^{41}$ Having been converted by slavers or illegally enslaved as Muslims, the girls were old enough to have a sense of their own religious identities. And having been through much forced change already, they initially resisted another change.

The missionaries maintained that they did not use compulsion to convert but hoped that once surrounded by Christian teaching and practice, the African girls would prove receptive to the message. Their schooling included Arabic, English, Bible, catechism, housekeeping, and sewing, and some of their names are recorded in Thompson's class lists. ${ }^{42}$ By May, Thompson reported a "kindly spirit ... toward the Christian religion". ${ }^{43}$ The school cook, an unnamed freed Sudanese slave, played a key role in this transition, and started prayer meetings for the girls that summer. Within two years, one had been baptized and received into the church; two others were requesting baptism. ${ }^{44}$ One of those was Susan, who stood out as the most eager to learn about Christianity: "she prayed very earnestly that she and her companions might be used to carry the Gospel light to their people," wrote her teacher Adela Brown. Perhaps the girls thought Christian missionary work would be a way to get back home. Brown, who had a hard time seeing beyond colour, reported that Susan was ahead of her class in Bible and catechism. "Her bright, sparkling eyes made her attractive (though she was very black), and her diligence and ambition cheered the heart of her teacher." In the fall of 189o, however, Susan grew ill, and in April 1891, four years after she had entered the school, she was taken to the hospital. Until then, the missionaries had delayed her baptism; but when she asked again to be baptized, one of the missionaries spoke to her about it. "She passed away that night and was brought to the church the next day in her coffin. A few of us followed her to her resting place". ${ }^{45}$ The missionaries took her lack of fear in the face of death to be a sign of Christian faith and victory, a soul saved, not a life lost.

\footnotetext{
41 Thompson, "Mission Work," 68.

42 PHS, Anna Thompson Papers, RG 58, box 1, folder 10, list of pupils.

43 PHS, Anna Thompson Papers, RG 58, box 1, folder 4; Thompson to Sisters of Ohio, Cairo, May 27, 1887; Halima, 7 .

44 Thompson, "The Women's Work in Cairo," January 30, 1889 in Women's Missionary Magazine 2 (1890): 273.

45 Brown, "Susan Ameen," 167.
} 
Mortality among the twelve freed slave girls at the Ezbekiah School was high. One had arrived ill and died shortly thereafter; three others subsequently passed away, two of whom, according to Henrietta Harvey, had "given their hearts to Jesus and died trusting in him alone." Henrietta's husband, Dr Harvey, had overseen the baptism of those girls, recording it in his diary. Henrietta admitted that the missionaries used to think slave mortality was high due to improper care, but experience showed that freed blacks also suffered from high rates of consumption. Arduous treks at young ages across deserts or by sea inflicted injuries and illnesses on the girls that shortened their lives. Even as Henrietta wrote, one girl was ill in her home. In spite of the loss of life, the missionaries took the conversions of the freed slave girls as a sign of their success.

Five years after Baring had sent twelve girls to the missionaries, only eight remained alive: one was ill; one was helping in a school in Asyut; one was a Bible woman under Anna Thompson's supervision; one who had been a servant was now in school at her own expense; one was set to go to Aden to teach freed slave girls in the Scotch Free Church mission with another Abyssinian (a plan that was delayed due to scurvy and fever in that mission); and three were servants in missionary families. ${ }^{46}$ One of the remaining eight later became matron of the Ezbekiah Boarding School under Ella Kyle. ${ }^{47}$

Of the original twelve girls, American Presbyterian missionaries chose to highlight Halima's life story, memorializing her in a pamphlet. For them, her life was exemplary, in part because it remained intertwined with the lives of the missionaries who had raised her and their descendants. American missionaries in Egypt were a tight-knit group who, having left most of their kin in the USA, reconstituted themselves as a family. Sometimes they were interrelated, as offspring returned to the field after schooling to take up posts, and intermarriages between missionary families created second and third generations in the field. The missionaries appended the freed African slave girls to their families, or collective family, in roles familiar for African Americans in the USA: as servants, housekeepers, and nannies.

46 Henrietta Harvey, "Letters from Egypt," Cairo, October 7, 1892, in Women's Missionary Magazine 6, no. 5 (December 1892): 122; Thompson, "Women's Work," 273.

47 Elizabeth Kelsey Kinnear, She Sat Where They Sat: A Memoir of Anna Young Thompson of Egypt (Grand Rapids: Eerdmans, 1971), 40-42. 
When Halima finished her schooling, she went with a missionary family to Asyut, where she took care of the home and children. She subsequently worked in other American and Egyptian homes, and "became a general favorite and was known in the mission community from Khartoum to Alexandria." Her pamphleteer tells us, she had "the pride and dignity of her race" and performed her service with "grace". In short, she served the church community well and was well liked, "Friendly and cheerful in disposition, she always rejoined [sic] to meet old friends or to make new ones". ${ }^{48}$

Her life took a turn at about the age of twenty-five or so when she was called into a new sort of service. In 1904, the American Mission in Egypt opened a hospital for women and children in Tanta, the fourth largest town in Egypt. Located in the Delta, Tanta was known for its mawlid, an annual celebration of the birth of a saint that drew thousands of visitors annually and prior to abolition had included a brisk market for slaves. Halima and four of the other freed slave girls arrived in Tanta in response to a call from Lulu Harvey, daughter of Henrietta and Dr Harvey. Lulu had become superintendent of nurses at the new hospital, but could not find native nurses. She turned to "the black girls whom she had known ever since their arrival in Cairo" to train them as assistants. ${ }^{49}$

Lulu used a strategy similar to the one deployed by Clot-Bey, the French medical expert hired by Mehmet Ali to modernize the practice of medicine in Egypt seventy years earlier. When Clot-Bey opened the School for Midwives, his first recruits were slaves, followed by orphans and daughters of deceased military men, in short, girls who had no family on hand to veto this line of work. ${ }^{50}$ Likewise, Lulu turned to freed slave girls—now women-as recruits for her first class of nursing trainees. Although Egyptian women trained in the School for Midwives and worked as health care practitioners, few indigenous women worked in hospitals as nurses; it was not considered a suitable profession due to the gender mixing in a hospital.

Lulu Harvey trained Halima and the others, who came to Tanta with literacy in English and Arabic and the experience of having served in missionary institutions and American homes. Importantly for service in a missionary hospital, which coupled the provision of health care with proselytizing, Halima was also a Christian. "To the Christians she was a sister in Christ—one whose faith gave one courage. To Mohammedans she was a bright example of Christian cour-

\footnotetext{
48 Halima, 7-8.

49 Halima, 8.

$5^{\circ}$ A.B. Clot-Bey, Apercu General sur L'Egypte, vol. 2 (Paris: Fortin, Masson, \& C, 1840), 425428; see Kozma, "Women on the Margins," 69.
} 
tesy and kindness".51 Halima joined the local Evangelical Church, where she was a regular attendee, and was considered a "born nurse". When the American hospital in Tanta was closed at the outbreak of World War I, Halima found employment in the English mission hospital in Cairo. She then entered the School for Midwives (at about the age of forty), earning her certificate and taking up a job in a government hospital. Upon the reopening of the American hospital in Tanta in 1919, at which time it was expanded into a general hospital, she returned. There she served private patients, including ill American missionaries. The latter gave testimony of her tender care, "the comfort of her hand", her "gentle" touch in giving back rubs and baths, and the ease with which she turned bodies. ${ }^{52}$

Yet missionaries and local Christians were not her only social circles. Halima had links with the small Ethiopian community in Cairo, through whom she learned definitively of her parents' deaths. Perhaps she had kept alive a hope of returning home to them one day. In 1928, at about the age of fifty-two, she retired from work at the hospital and married a younger Ethiopian man living in Cairo, finally settling down. The missionary community feared the younger man was after her money and initially begrudged her the companionship and intimacy that marriage might bring. Having worked for half a century and lived in other peoples' homes, she established her own home and balcony garden. At the same time, she rekindled ties with some of her "sisters", the freed slaves from boarding school days. When one was widowed and unable to care for her daughter, Halima took the girl in and raised her as her own. "The joy and pride of motherhood became hers in this girl," her pamphleteer wrote. The girl later became the wife of the Ethiopian ambassador to the USA. With a "daughter" to support, Halima went back to work as a nurse, caring for the mother of one of the missionaries. In her leisure in the invalid's home, she read from her Arabic Bible and the Women's Missionary Magazine. But the nurse was losing strength and was sent to Tanta Hospital for testing. There she was diagnosed with terminal cancer and died in August 1934 at about the age of fifty-eight in the hospital where she had served for decades. ${ }^{53}$

Her pamphleteer concluded, "It had been no small responsibility to take into a little school family twelve wild orphans of another race and color. Infinite patience and Christian love were lavished on the child Halima. How gloriously

51 Halima, 8-9.

52 Halima, 8-9.

53 Halima, 10-14. 
she repaid the sacrifice." Her devotion, service, and "victorious testimony in the hour of death" reaffirmed the missionaries' decision to take in the freed slave girls sent by Baring. ${ }^{54}$ Of all the freed African slave girls, Halima's life most closely followed the missionaries' script for a life of service, at least in their telling. Halima's perspective remains elusive.

\section{$5 \quad$ Conclusion}

Egyptian slave traders and owners, British abolitionists and colonial officials, and American missionaries all had plans for the twelve African girls. Traders looked to make a quick profit, owners needed household labour, abolitionists sought to rescue them from forced servitude, colonial officials planned to refashion them as wage earners, and missionaries dreamt of converts, church workers, and saved souls. Given their high rates of conversion and the occupations they took up, the girls fulfilled Anna Thompson's original hopes for them. Of those placed in the school, a third died prematurely but not before accepting Christianity, which the missionaries took as a sign of their success. Others survived to carve out lives within set parameters, serving in missionary schools, hospitals, and homes. The girls were tracked into lives of service for the missionary community in the lower rungs, or as teachers for other Africans, rather than in more prestigious church professions. But they occasionally challenged the parameters, with one funding her own further education, another resisting the pressure to convert, and a few establishing families, showing that the girls and women they became sought to shape their own lives.

As far as we know, none of the twelve went or were sent back home to their own country to find their families, though that is a return passage that some freed slaves took. Those running manumission boards and refuges found this journey impractical and gave freed slaves little support to return home. Only a few started their own families. Given their long hours of domestic service in missionary homes, as matrons in boarding schools, or nurses in hospitals, they spent large portions of their lives raising and caring for other peoples' children rather than conceiving and raising their own. Their work was productive, not reproductive, and they left few descendants who might carry the collective memory of slavery and remember their individual stories. Instead, they lived mostly single, and sometimes isolated, lives. They retained bonds 
with the missionaries who had raised and schooled them and for whom they worked. They also tapped into immigrant and religious networks, and created links of their own. In whatever time they had spent together in the rough passage to Egypt through Jidda or Asyut or some other route, in the Home for Freed Women Slaves, and in the Ezbekiah Boarding School, these Africans developed close attachments to one another. They studied and worked together, and turned to one another in times of need. Their lifelong bonds helped to see them through periods of transition, sickness, and death. In the absence of kin, they spoke of one another as "sisters" and created a "feeling of family fellowship" that lasted a lifetime..$^{55}$ These networks eased their alienation in a society that placed family ties at the centre but in which they stood out as racially other.

The experience of these twelve freed African slaves shows that the end of slavery was neither swift nor painless. Caught in the last throes of the slave trade almost a decade after it had been banned, the twelve were forcibly separated from their parents; smuggled in harsh conditions overland and by boat to Egypt; faced disease and sometimes early death; were pressured, sometimes repeatedly, to adopt a new religion and name; worked in the homes, schools, and hospitals of a group that considered them sisters in Christ but racially inferior; and had little opportunity to create their own families. The impact of the institution of Egyptian slavery on the African societies from which these and other children and adults were taken was devastating as well. The lives that emerge from missionary and abolitionist sources are fragile and fragmented, but the sources begin to give faces, names, and voices to these freed slaves.

\section{Bibliography}

Aysut, Muhafazat. Asyut fi 10 Sanawat. Cairo: Matbaat Nahdat Misr, 1962.

Baer, Gabriel. "Slavery in Nineteenth Century Egypt." Journal of African History 8, no. 3 (1967): 417-441. Reprinted as "Slavery and Its Abolition." In Studies in the Social History of Modern Egypt, chapter 10. Chicago: University of Chicago Press, 1969.

Baron, Beth. Egypt as a Woman: Nationalism, Gender, and Politics. Berkeley: University of California Press, 2005.

Brown, A.A. "Susan Ameen," Cairo, Nov. 1891. Women's Missionary Magazine 5, no. 6 (Jan. 1892). 
Clot-Bey, A.B. Apercu General sur L'Egypte. Volume 2. Paris: Fortin, Masson, \& C., 1840 ,

Crewe, E. “The Slave Trade in Egypt," Cairo, April 9, 1886. Anti-Slavery Society (May-June 1886).

Elbashir, Ahmed E. The United States, Slavery and the Slave Trade in the Nile Valley. Lanham: University Press of America, 1983.

Elder, Earl. Vindicating a Vision: The Story of the American Mission in Egypt, 1854-1954. Philadelphia: United Presbyterian church of North America, 1958.

Erdem, Y. Hakan. Slavery in the Ottoman Empire and Its Demise, 1800-1909. New York: St Martin's Press, 1996.

Halima-The Gentle One. Pittsburgh: Women's General Missionary Society, United Presbyterian Church of North American, n.d.

Harvey, Henrietta. "Letters from Egypt," Cairo, October 7, 1892. In Women's Missionary Magazine 6, no. 5 (Dec. 1892).

Hilal, Imad. Al-Raqiq fi Misr fi al-qarn al-tisa' 'ashar. Cairo: al-'Arabi, 1999.

Hilal, Imad. "The Anti-Slavery Movement in Egypt in the Nineteenth Century: Between Shari'a and Practice." (Paper presented at a workshop on "Race and Slavery Between the Middle East and Africa." cuny Graduate Center, April 23, 2004).

Hunwick, John and Eve Troutt Powell. The African Diaspora in the Mediterranean Lands of Islam. Princeton: Markus Wiener Publishers, 2002.

Hunwick, John. "The Religious Practices of Black Slaves in the Mediterranean Islamic World." In Slavery on the Frontiers of Islam, edited by Paul E. Lovejoy, 149-171. Princeton: Markus Wiener Publishers, 2004.

Kinnear, Elizabeth Kelsey. She Sat Where They Sat: A Memoir of Anna Young Thompson of Egypt. Grand Rapids: Eerdmans, 1971.

Kozma, Liat. "Women on the Margins and Legal Reform in Late Nineteenth-Century Egypt, 1850-1882." PhD diss., New York University, 2006.

La Rue, George M. "The Capture of a Slave Caravan: The Incident at Asyut (Egypt) in 188o." African Economic History 30 (2002).

McKown, M.J. “Girls' School Assiout, Egypt.” Women's Missionary Magazine vol. 3, no. 11 (June 189o).

Mowafi, Reda. Slavery, Slave Trade and Abolition Attempts in Egypt and the Sudan 18201882. Stockholm: Esselte Studium, 1981.

Pursley, Sara. "From Civil War to Civilizing Mission: American Military Officers in the Egyptian Service, 1869-1879." (Paper presented at a workshop on "Race and Slavery Between the Middle East and Africa," cunY Graduate Center, April 23, 2004).

Robinson-Dunne, Diane. The Harem, Slavery and British Imperial Culture: Anglo-Muslim Relations in the Late Nineteenth Century. Manchester: Manchester University Press, 2006. 
Sharkey, Heather J. American Evangelicals in Egypt: Missionary Encounters in an Age of Empire. Princeton: Princeton University Press, 2008.

Starbuck, Charles C. “Theological and Religious Intelligence.” The Andover Review (May 1889).

Thompson, Anna. “The Women's Work in Cairo." (Jan. 30, 1889). Women's Missionary Magazine 2 (1890).

Thompson, Anna Y. “Mission Work in Egypt." Women's Missionary Magazine 5, no. 3 (October 1891).

Toledano, Ehud R. Slavery and Abolition in the Ottoman Middle East. Seattle: University of Washington Press, 1998.

Toledano, Ehud R. As If Silent and Absent: Bonds of Enslavement in the Islamic Middle East. New Haven: Yale University Press, 2007.

Troutt Powell, Eve M. A Different Shade of Colonialism:Egypt, Great Britain, and the Mastery of the Sudan. Berkeley: University of California Press, 2003.

Tucker, Judith E. Women in Nineteenth-Century Egypt. Cambridge: Cambridge University Press, 1985 .

Whately, Mary L. Letters from Egypt to Plain Folks at Home. London: Seeley, Jackson, \& Halliday, 1879 .

\section{Anti-slavery Reporter Editions}

"Egypt." March-April 1893.

January 1885 .

August 1885 .

Scott-Moncrieff, C. Letter, Cairo, October 6, 1885. December 1885 .

Crewe, E. "The Slave Trade in Egypt." Cairo, 9 April 1886. May-June 1886.

Scott-Moncrieff, C.C. “The Treasurer's Report-1886.” May-June 1886.

May-June 1886.

Du Port, M.S.P. "Report of the Cairo Committee of the Year 1886." March-April 1887.

"The Christian." (June 3, 1887) May-June 1887.

\section{Rhodes House Library}

BFAAPS, S22, G25, Africa, No. 4 (1887). Correspondence Respecting Slavery in Egypt, Inclosure 2 in No. 1, Lieutenant-Colonel Schaefer to Captain Crawford, Commandant, Suez (October 25, 1886).

BFAAPS, S22, G25, Africa, No. 4 (1887). Correspondence Respecting Slavery in Egypt, Inclosure 1 in No. 1, Schaefer to Sir E. Baring, Cairo (December 16, 1886).

B FAAPS, S22, G25, Africa, No. 4 (1887). Inclosure 3 in No. 1, Schaefer, "Etat Nominal des Esclaves importes pendant le Saison du Pelerinage de 1886." 


\section{Presbyterian Historical Society (PHS)}

Anna Thompson Papers, RG 58, box 1, folder 4, Notebook: Red Letter Days.

Anna Thompson Papers, Arabic manumission certificate, RG 58, box 1, folder 8 .

Anna Thompson Papers, List of pupils, RG 58, box 1, folder 10.

Anna Thompson to Sisters of Ohio. Cairo, May 27, 1887.

Margaret Anna Smith Diary, RG 404, box 1, folder 3, August 25, 1878. 


\title{
Physical Expressions of Winning Hearts and Minds: Body Politics of the American Missionaries in "Asiatic Turkey"
}

\author{
Nazan Maksudyan
}

This paper discusses the use of visual representations or photographic descriptions by the missionaries of the American Board of Commissioners for Foreign Missions (ABCFM) as proofs of their proselytizing efforts. The analysis is limited to the American missionaries of the "Asiatic Turkey Mission", namely Western Turkey Mission (established in 1819), Central Turkey Mission (1847) and Eastern Turkey Mission (1836), whose proselytizing efforts centralized its work mainly on Armenians. ${ }^{1}$ I argue that bodily conditions of targeted constituencies and their physical surroundings (rooms, houses, villages) were reconceived and re-conceptualized by American missionaries as material representations and mirrors of religious and moral progress. This was usually done in the genre of before-and-after photographs or detailed physical descriptions, one criticizing or pitying the former "wretchedness" of people, and the other appraising how they "grew finer". Assuming that sincere belief, or for that matter conversion, is a delicate matter to present evidence for, these visual representations or descriptions were useful tools to convince the world of believers and benevolent contributors that these people were genuinely "civilized" into good Christians and were leading a Christian life.

The ABCFM, founded in 1810, established its first missions in the Ottoman Empire in 1819 and became by the second half of 19th century quite influential in the Anatolian provinces of the Empire, especially in socio-cultural fields of relief, education, and health. ${ }^{2}$ The specificities of their experience

1 For more information on the work of ABCFM missionaries among the Armenians, see Barbara J. Merguerian, "'Missions in Eden': Shaping an Educational and Social Program for the Armenians in Eastern Turkey (1855-1895)," in New Faith in Ancient Lands: Western Missions in the Middle East in the Nineteenth and Early Twentieth Centuries, ed. Heleen Murre-van den Berg. sсм 32 (Leiden: Brill, 2006), 241-262.

2 There were substantive regional differences in target populations, experiences and strategies of American missionaries stationed in different parts of the Ottoman Empire, namely the Balkans, Anatolia, Arab provinces. Compared to their relatively safe and well-established stand in most of the Anatolian provinces, the American missionaries did not necessarily gain 
in the Ottoman lands-successive failure among the Muslims and then the Jews, and later never-ending controversies with Orthodox communities, both Armenians and Greeks - made the ABCFM alter their approach from a narrow effort to "save souls" into a broad program of "cultivate minds". ${ }^{3}$ The ABCFM missionaries realized early on that the communities would not easily receive a missionary simply as a preacher of the gospel, but they would accept a school (a teacher) or an infirmary (a doctor) quite willingly. Thanks to their educational, medical, and humanitarian services, the АВCFM missionaries served as a second layer of communal support-in addition to the one that the communities formally belonged. They successfully used these institutions to have access to other religious denominations, since they admitted everyone in their schools and hospitals, not necessarily to convert them, but "make an impression" upon them as to "what true Christianity is". Elshakry argued that even though American missionaries "failed in their mission to save souls - their success in terms of numbers of actual converts to the Protestant Church was never very impressive - they were nevertheless said to have helped win the battle for the 'conversion to modernities'4 in the Middle East". 5 That is why, Protestantism as represented by the ABCFM became a main ideological enemy in the eyes of the Sultan, since it was considered as one of the major factors in the renaissance of Armenian and Syriac self-consciousness, especially because of their emphasis on the use of vernacular languages. ${ }^{6}$

As the main material of this essay, I concentrate on an interesting section of the Missionary Herald, one of the mostly circulating Board publications:

much local respect in the province of Syria. See for instance, Habib Badr, "American Protestant Missionary Beginnings in Beirut and Istanbul: Policy, Politics, Practice and Response," in New Faith in Ancient Lands: Western Missions in the Middle East in the Nineteenth and Early Twentieth Centuries, ed. Heleen Murre-van den Berg (Leiden: Brill, 2006): 211-240; Ussama Makdisi, The Culture of Sectarianism: Community, History, and Violence in Nineteenth-Century Ottoman Lebanon (Berkeley: University of California Press, 200o).

3 Barbara J. Merguerian, "Saving Souls or Cultivating Minds? Missionary Crosby H. Wheeler in Kharpert, Turkey," Journal of the Society for Armenian Studies 6 (1992-1993): 33-6o; Ellen Fleischmann, "Evangelization or Education: American Protestant Missionaries, the American Board, and the Girls and Women of Syria (1830-1910)," in New Faith in Ancient Lands. Western Missions in the Middle East in the Nineteenth and Early Twentieth Centuries, ed. Heleen Murrevan den Berg (Leiden: Brill, 2006), 263-280.

4 Peter van der Veer, ed., Conversion to Modernities: The Globalization of Christianity (New York: Routledge, 1996).

5 Marwa Elshakry, "The Gospel of Science and American Evangelism in Late Ottoman Beirut," Past and Present 196, no. 1 (2007): 173-214.

6 Hans-Lukas Kieser, "Mission as Factor of Change in Turkey (Nineteenth to First Half of Twentieth Century)," Islam and Christian-Muslim Relations 13 (2002): 391-410. 
"For Young People". Starting from 1879, each monthly issue included a brief illustrated article designed for "young people". This designation is in itself interesting, since it is not certain if the target audience was essentially children. If we assume that it was so, the age group must have shaped the narratives and focus of the stories and photos. This might explain less precision and more generalization (in an Orientalistic fashion) in describing different religions, ethnic groups, and manners and customs. Yet, the young readers understandably were not expected to support the ABCFM financially, but they were prepared for future support. Moreover, since "For Young People" was a part within the Missionary Herald, the section editors were mainly appealing to the preferences and worldviews of their principal readers, the parents. After all, it was them who would financially support the AвCFM. Thus, the target group of the section was children as much as the adults.

Shortly after its appearance, it was concluded that "Young People" department met a real demand and that these articles were widely read. Many of them were copied into other magazines and religious papers in the United States and in Great Britain. Moreover, they were compiled in two books, one in 1885 and the other in 1897, as a collection under the name of Mission Stories in Many Lands: A Bookfor Young People. ${ }^{7}$ They were purchased for Sunday School libraries and also used by Mission Circles and Young People's Societies of Christian Endeavor. With their illustrations and touching stories, they became one of the Board's main PR outlets to advertise their success at proselytizing and collect more donations.

Accounts of people and scenes in lands far away, and of the heroic men and women who have labored with zeal and success for the good of men of other climes and tongues, are among the best sources of instruction and stimulus for readers young or old. ${ }^{8}$

Many of these stories focused on the misery of people and life in general in "Asiatic Turkey". The first group of articles focused on and told stories of those who were genuinely physically deprived and in real destitution, such as lepers, the orphaned, starved, and sick. As a second strategy, they interpreted the bodies, surroundings, and dwellings of regular (not sick or destitute) people also within this general picture of misery. In other words, healthy people's bodies,

7 Mission Stories of Many Lands: A Book for Young People (Boston: The ABCFM, 1885); In Lands Afar: A Second Series of Mission Stories of Many Lands, A Book for Young People (Boston: ABCFM, 1897).

8 In Lands Afar, iv. 
dress, cleanliness, grooming was pathologized, together with their dwellings, villages, and even interpersonal relations. These were presented as deformed, degrading, undignified, and heathen and the АВСFM missionaries defined their role as fixing these through conversion to Protestantism. Protestant missionary indoctrination through sermons, everyday interaction, school education and medical care was to reform people and places, both materially and spiritually, into "good-looking and Christian" entities. Therefore, the changes in human bodies and people's living conditions were presented as representations of internalization of Christian teachings. Those who received some form of Protestant influence were miraculously leaving their old habits behind and were reborn as new men and women. It is in fact telling that the American missionaries positioned themselves as quasi-physicians: they were there to heal not only real diseases and deprivations, but also the social and spiritual ills.

A third group of articles was purportedly anthropological/sociological pieces on various ethnic/religious groups in the Empire, such as Kurds, Armenians, Greeks, Yezidees, Albanians, and so on. These are purely Orientalist descriptions of their traditional costumes, cuisine, and "national character". ${ }^{9}$ Photographs accompanying the articles acted in a precise way to establish specific stereotypes and markers of inferiority, both of the people and of their homelands. Photographs also expressed distinctions between "Oriental peoples" and missionaries from an ambivalent point of view: As agents of "a superior culture", they most often envisioned their subjects as objects of both inferiority and fascination..$^{10}$

Visual Representations of Conversion: Before-and-After Photographs

As soon as photography was introduced to the Ottoman Empire by the midnineteenth century, ${ }^{11}$ missionaries started to use it as a way to authenticate

$9 \quad$ In their study of postcards, Malek Alloula and David Proschaska show how photography evinced Orientalist discourse. Malek Alloula, The Colonial Harem (Minneapolis, Minn.: University of Minnesota, 1986); David Prochaska, "Archive of l' Algerie Imaginaire," History and Anthropology 4 (1990): 373-420.

10 Eleanor M. Hight and Gary D. Sampson, eds., Colonialist Photography: Imag(in)ing Race and Place (London: Routledge, 2004), 1.

11 The first known photograph is of Rais al-Tin Palace, in Alexandria, taken on November 7 , 1839. For more information, see Jacob M. Landau, Exploring Ottoman and Turkish History (London: Hurst \& Co., 2004), 101-104; Engin Çizgen, Photography in the Ottoman Empire (Istanbul: Haşet Kitabevi, 1987); Wolf-Deiter Lemke, "Ottoman Photography: Recording 
their experiences in distant parts of the world and to establish "a visual impression of 'heathenism' more dramatic than could be achieved with the written word". ${ }^{12}$ Next to tourists, painters, artists, art historians and journalists, missionaries were a large group of photographers in the Empire. They found it useful to illustrate their tracts with photographs, and so from early on the mission stations tried to acquire the necessary equipment and know-how to take and print photographs. ${ }^{13}$ By the late 19th century, photography became an established part of different forms of field work, including Christian ministry.

The discourse of before-and-after was always omnipresent in АВCFM publications. It conveyed an image of accomplishment on the part of the missionaries and a promise of remarkable alteration on the part of the targets. Therefore, the relationship between conversion and visual representation was a strong one, in which photographs operated as complex discursive objects of power and culture. ${ }^{14}$ As eyewitness evidence of Ottoman reality, photographs played a significant part in reproducing the stereotype that Ottomans were degenerates in need of guidance from the Protestants. ${ }^{15}$ The pictures of those whose physical features in terms of dress, cleanliness, or posture were dramatically inferior, potentially hostile, or disruptive were used in the "before narrative" in order to justify the value of Protestant missions.

As proofs of reclamation of freedom for the "long-enslaved Eastern Churches", of "spiritual conquest of the people", mainly of evangelization, they relied on showing how despicable pre-missionary life was and how it wonderfully improved with the intervention of the Protestants. Formulaic conversion anecdotes published alongside a pair of photographs (often one taken before and other after supposed conversion) within the reports and articles that appeared in the Missionary Herald served as proofs of achievement in the field, which was necessary to legitimate the continuing flow of funds. They reinforced the difference of the "other" and therefore the need for missions as

and Contributing to Modernity," in The Empire in the City: Arab Provincial Capitals in the Late Ottoman Empire, eds. Jens Hanssen, Thomas Philipp, and Stefan Weber (Beirut: Ergon Verlag Würzburg, 2002), 237-249.

12 Barbara Lawson, "Collecting Cultures: Canadian Missionaries, Pacific Islanders, and Museums," in Canadian Missionaries, Indigenous Peoples: Representing Religion at Home and Abroad, eds. Alvyn Austin and Jamie S. Scott (Toronto: University of Toronto Press, 2005), 256 .

13 Landau, Exploring Ottoman and Turkish History, 103.

14 Hight, Colonialist Photography, 1.

15 Ayshe Erdogdu, "Picturing Alterity: Representational Strategies in Victorian Type Photographs of Ottoman Men," in Colonialist Photography: Imag(in)ing Race and Place, eds. Eleanor M. Hight and Gary D. Sampson (London: Routledge, 2004), 122. 
assimilating and evangelizing forces. In that sense, the American missionaries depended on the ability of the photographs to convey "a sense of mission to the viewer who responded with increased prayer and increased giving." 16

All the articles in the "For Young People" were published along with visual material, such as photographs, engravings and drawings. When there was no visual to display certain people and places, the American missionaries relied on their literary skills and provided very detailed, even photographic descriptions. The visual qualities of the articles mirrored the missionaries' understanding of the propagandistic power of photographs when placed alongside personal testimony. They were used as tools to tangibly confirm that evangelical activity had yielded widespread cultural and spiritual transformation. American missionaries' reports largely relied on transformation of the bodies and physical surroundings of the people of "Asiatic Turkey". In that sense, changes in the living conditions and customs of the people, "social progress" as it was presented, was the main indicator of conversion.

The missionaries used photography as if it can also capture people's beliefs. In their quest to give visibility to "true Christianity", they had to devise solid, material proofs of inner belief that one can see. Therefore, ironically, true faith, which the Protestants praised without concession, was actually reduced into a set of material, observable traits. Although social change was presented as the spillover effect of proselytizing, in fact it was the essence of conversion itself. People were, in effect, converted into a certain definition of "civilization" (with its tangible definitions of cleanliness, neatness, nutrition, hygiene, home, domesticity, family life, order, child-rearing, and so on) rather than into an abstract set of rules (religion).

"Growing Fine": Armenian Orphans and the АвсFM

The American missionaries' "visual success" was crystallized in the description and depiction of the orphans in their orphanages. These children were in a most extreme destitution before arrival and were under absolute missionary control thereafter. The ABCFM had always embraced philanthropy as a part of its missionary mandate. The missionary work was divided into four departments. Next to evangelistic work, publication, and education, philanthropy was an important part of the missions. ${ }^{17}$ The missionaries organized

16 Carol Williams, Framing the West: Race, Gender, and the Photographic Frontier in the Pacific Northwest (Oxford: Oxford University Press, 2003), 88.

17 Rev. George F. Herrick, "Canon Taylor on Missionary Methods," Missionary Herald vol. 85 (January 1889): 13-16. 
local relief measures in the case of fires, earthquakes, famines, and diseases. Relief for the orphans had one outstanding advantage, given manifold religious and social limitations of the American missionary establishments: they were free from family ties, which made conversion to Protestantism very difficult or even impossible. ${ }^{18}$

The opening of the ABCFM orphanages within the "Asiatic Turkey" mission started after the Armenian massacres of $1894-1896,{ }^{19}$ which orphaned around $5^{0}$,ooo children. ${ }^{20}$ Before that, the missions only had three very small-scale asylums. But these events forced the missionaries to open more than sixty orphanages in around thirty districts. The number of orphans in each orphanage ranged from $5^{\circ}$ to 1,000 , though they had in average about 100 children. The orphan asylums of the ABCFM were thought to have provided for around 10,00o orphans in the following decade after the massacres. These massacres made the missionaries content with their operations, as they had found a great opportunity to make a massive impact on the local population. ${ }^{21}$

Before-and-after narrative was strong in American missionary writings about orphans and orphanages. Long depictions of children's bodily features were provided, describing in detail how they were received in miserable conditions of dirt, sores, and vermin and how they were tamed in the hands of the missionaries into clean, good-looking, and well-behaved children. Orphan girls, coming "literally in rags", without "shoes or anything warm for winter", were furnished with "plain but neat cotton or woolen dresses". ${ }^{22}$ They were now "clean,

18 Roland Löffler, "The Metamorphosis of a Pietistic Missionary and Educational Institution into a Social Services Enterprise: The Case of the Syrian Orphanage (186o-1945)," in New Faith in Ancient Lands: Western Missions in the Middle East in the Nineteenth and Early Twentieth Centuries, ed. Heleen Murre-van den Berg. SCM 32 (Leiden: Brill, 20o6), 157.

19 For further information on the Eastern Anatolian Armenian massacres in the late 189os and the involvement of the American Protestant missionaries in the relief efforts, see Hans-Lukas Kieser, Der verpasste Friede: Mission, Ethnie und Staat in den Ostprovinzen der Türkei 1839-1938 (Zurich: Chronos Verlag, 2000); Selim Deringil, “'The Armenian Question is Finally Closed': Mass Conversions of Armenians in Anatolia during the Hamidian Massacres of 1895-1897," Comparative Studies in Society and History $5^{1}$ (2009): 344-371; Margaret Lavinia Anderson, “'Down in Turkey, Far Away': Human Rights, the Armenian Massacres, and Orientalism in Wilhelmine Germany," The Journal of Modern History 79 (2007): 80-111.

20 It was generally argued by the contemporaries that there were around 50 ,ooo destitute orphans. "Editorial Paragraphs," Missionary Herald vol. 95 (October 1899): 396; "Fifty Thousand Orphans made so by the Turkish Massacres of Armenians," New York Times, December 18,1896 .

21 Nazan Maksudyan, "'Being Saved to Serve': Armenian Orphans of 1894-96 and Interested Relief in Missionary Orphanages," Turcica 42 (2010): 47-88.

22 Miss Nason, “Work for Orphans," Missionary Herald vol. 93 (March 1897): 112-113. 
merciful, obedient, rapidly learning both in books and in Christian life, so different from the wretched little creatures they were when they first came in". ${ }^{23}$

The ABCFM missionaries tried to change behaviors and social attitudes of the orphans by implementing Protestant work ethics. Among their main pedagogical aims were cleanliness, passion and continuity at work, teamwork, and mutual responsibility. ${ }^{24}$ The American missionaries argued that the orphans they had sheltered, clothed, cared for, and disciplined were regarded with admiration by the whole community around them, as their physical conditions improved after they were institutionalized. An anecdote from Urfa exemplifies the perception.

As these boys were taking a walk on a recent day a group of people stopped to gaze at them, and one said, 'Does Miss Shattuck pick out all the fine boys in the community for her orphanage?' 'No' replied another, 'they grow fine after she has had them a little while.'25

As dirty, half-starved and neglected orphans, they were "other children", based on otherness of need, poverty, and undesirability. The missionary relief thus made them both "children" and believers. Orphanages were a useful tool to convince the world of believers and benevolent contributors of the progress realized with these "other children". Thus, children were not only physically cleaned and cared for, but they were transformed into "sleek, bright and interesting" children and true members of the Protestant community.

We could wish the city claimed a photographer as then we could enclose a couple of contested pictures of some of these 'wards of Christendom' as they appeared upon reaching the Home-dirty, ragged, emaciated, covered with sores and vermin - and as they appear now—clean, comfortably clothed, sleek, bright and interesting. The transformation is wonderful. ${ }^{26}$

Missionaries were so convinced of the power that photography exerted upon their supporters and contributors that Dr Gates of Harput even wrote that if he were able to send pictures "of these wretched, wan little waifs he would not

23 "Merzifon Station Report, 1897," ABC 16.9.3, reel 6o6, nos. 698-67o.

24 Löffler, "The Metamorphosis of a Pietistic Missionary," 161.

25 "Editorial Paragraphs," Missionary Herald vol. 93 (June 1897): 216. (Italics mine).

26 "Mardin Orphanage, Reports for 1897-1899," ABC 16.5, reel 512, nos. 201-230. The quote was taken from to "Report of Mardin Orphan Department for 1897." 


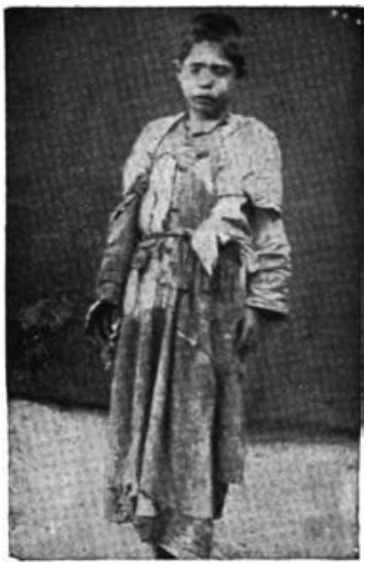

FIGURE 3.1

Aram (before photograph). Reproduced from "For Young People: Orphans in Turkey," Missionary Herald vol. 94 (May 1898): 204-208

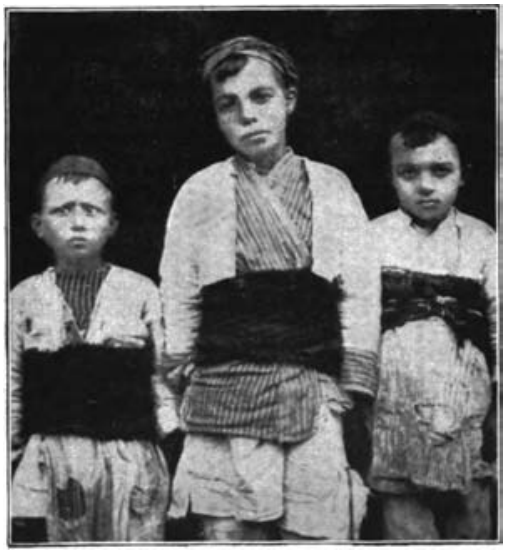

FIGURE 3.2

Boys coming to Home (before photograph). Reproduced from "For Young People: Orphans in Turkey," Missionary Herald vol. 94 (May 1898): 204-208

need to write anything". ${ }^{27}$ Actually, the article contains a photo-engraving of an orphan, Aram as he is called, taken just as he came to the orphanage at Harput. However, in reality "this boy was not as destitute and wretched as many of the children were when they first came" (Figure 3.1). ${ }^{28}$

Another photograph of three little boys, also "taken just as when they came", is also not so impressing (Figure 3.2).

In other words, these "before" pictures were not as heartbreaking and shocking as Dr Gates wanted it to be. Just as in the case of lamenting for not finding a photographer to document the before-and-after conditions of children,

27 "For Young People: Orphans in Turkey," Missionary Herald vol. 94 (May 1898): 204-208.

28 Ibid., 204. 


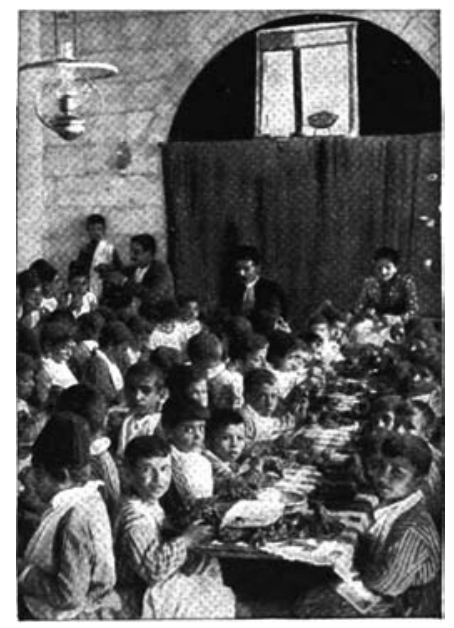

FIGURE 3.3

Orphans at Oorfa at dinner (after photograph). Reproduced from "For Young People: Orphans in Turkey,"

Missionary Herald vol. 94 (May 1898): 204-208

the missionaries regretted the fact that the photograph could not capture the extent of misery they wanted to present to the world. Still the sense of contrast created with "after" pictures was thought to compensate for it.

But it does not take a great while to change their whole appearance. They are washed and clean but coarse clothing is given to them, and they are fed on simple food, which seems to them like the greatest of luxuries. The contrast between Aram and some of the pictures which follow will indicate in some degree what this orphanage work has done for the children. ${ }^{29}$

In a picture, boys from the orphanage at Urfa were shown at dinnertime. They were neatly dressed, well-prepared within the dining hall, with a smile on their faces. This time the missionary described both the kind of food they were about to have and the religious content of their upbringing in the orphanage by referring to the blessing they prayed for just before starting to eat (Figure 3.3).

The boys are sitting on the floor matting, each one having a tin plate filled with grapes. Cucumbers and bread are arranged in little piles on the table. The house father and house mother are seated at the farther end of the table and the boys are looking up, just after the blessing has been asked. ${ }^{30}$

29 Ibid.

$30 \quad$ Ibid., 206. 


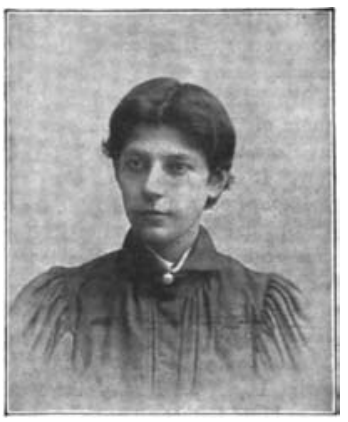

FIGURE 3.4

A rescued orphan girl (after photograph). Reproduced from "For Young People: Orphans in Turkey," Missionary Herald vol. 94 (May 1898): 204-208

In another story about the Armenian orphans under the care of American missionaries, again two photographs were used and the reader was warned to "look on this picture and then on that" in order to comprehend "what changes are wrought by this work for orphans". ${ }^{31}$ The "medicine" that brought about the complete transformation was apparently nothing but the religious instruction that they were providing (Figure 3.4).

It is not a patent medicine that we are advertising ... All four of these children are Armenian orphans ... of November 30, 1895. The boys were photographed just as they came to us. [Figure 3.2] The girl was photographed after a year spent in the pleasant parsonage in Germany to which she was sent after her terrible experience. The medicine that wrought the change was simply a practical application of the Master's words, 'Ye ought also to love one another'.32

According to ABCFM's interpretation, the Armenians were the most appropriate targets of conversion activity. Even among the Armenians, missionaries had difficulty entering into communities. Crisis periods, when the community was in need of humanitarian assistance, were beneficial for the missionaries. The misery of the people could always be turned into an "opportunity". The Armenian massacres of 1894-1896 created a similar atmosphere of hopefulness and heightened visions for conversion. As I have discussed elsewhere, the missionaries in the field were more than content, as they had finally found a great opportunity to make a massive impact on the local population. ${ }^{33}$ The Armenian

31 Ibid., 207-208.

32 Ibid., 207-208.

33 Maksudyan, "'Being Saved to Serve'” 
orphans were often defined as invaluable targets, since the missionaries hoped that "many of the orphans" would "give themselves to Christ" and would "love a Christian life". 34

\section{3}

\section{A Christian Body, a Christian Home}

The American missionaries assumed that inner religious beliefs were perceptible through material state of bodies. Styles of dress, manners, physical decorum, and cleanliness were taken to be outward signs of evangelical piety and virtue. Therefore, embracing Western-style clothing and hairdressing, postures, and rules of hygiene were coupled with conversion to Protestant faith. Transition from false to true Christianity required a process of bodily refashioning, imposed by missionaries' own standards of clothing, appearances, conduct, sanitation, and hygiene. ${ }^{35}$ In their efforts to tame and correct bodies, the American missionaries, first of all, underlined the importance of cleanliness and personal hygiene and worked hard to foster "cleanliness as a social virtue" in many places where they established missions. Converts were claimed to become "more prepossessing and more tidy in person and environment", to such an extent that they were visibly recognizable by their state of hygiene.

Missions have done much to teach personal cleanliness and household hygiene. The homes of all girls educated in mission schools are conspicuous for their betterment in this regard. Protestant families are models to all in the matter of neatness and freedom from slovenly habits. ${ }^{36}$

The ABCFM missionaries frequently argued that "dirt is domesticated in the homes of the people" and "disgusting slovenliness - in many instances intolerable filth-is more or less characteristic of the individual". ${ }^{37}$ Therefore, as an initial target American missionaries attempted to "baptize the villages and

34 George E. White, "Annual Report of Merzifon Station 1905-19o6," salt Archives, American Board of Commissioners for Foreign Missions, ABAASRooo313, https://archives.saltresear ch.org/handle/123456789/46791.

35 For photography's role in the representation of the body and forms of social discipline, see Suren Lalvani, Photography, Vision, and the Production of Modern Bodies (Albany, N.Y.: State University of New York Press, 1996).

36 Rev. James S. Dennis, Christian Missions and Social Progress: A Sociological Study of Foreign Missions (New York: Fleming H. Revell Company, 1899), 459 (Report of Dr Geoger E. Pist of Beirut). (Italics mine).

Dennis, Christian Missions, 458. 
homes". They were extremely critical of many aspects of local domestic life, from sleeping and living in the same room to eating from a common pot. They claimed that "neither in the Turkish or Armenian language is there any word for home", and that all that there is, is "a house or dwelling-place."38 Houses and physical surroundings were among the first targets of evangelization; and this meant teaching and imposing their own standards of "home" on the natives. Based on their physical and material expectation of a home, the missionaries worked for the inculcation of a new sense and concept of home, together with new home ethics and home economics. ${ }^{39}$

American missionaries described the social life of the Ottomans as "one of great degradation". 40 As people's dwellings usually consisted of just one room, the missionaries argued that they were "living and eating and sleeping like domesticated animals". ${ }^{41}$ In a consistent and repeated manner, houses were compared to stables and people to animals. Within this discourse, "the whole family herded" in an "often filthy and unwholesome" room. ${ }^{42}$ In a similar fashion, many families were "content to occupy the same winter quarters as their cattle, in dark, unventilated stables". ${ }^{43}$

The most compelling duty of the Christian missions was to teach the basics of sanitation and cleanliness. It was declared with pride that with the establishment of the mission stations, the living conditions of the locals were dramatically transformed and uplifted "from that of the beasts to that of men", "from barbarity to the level of civility". New minds "aroused by the Gospel", were not simply building additional rooms in their houses, but they were in fact starting to appreciate "the fact that man is higher than the animal, and so worthy of a better place in which to live." 44 Projecting the language and jargon of proselytizing onto physical surroundings and places, АBCFM missionary reports underlined that "great and blessed changes" were apparent in thousands of homes thanks to the direct influence of mission work. ${ }^{45}$

38 "For Young People: The Empire of the Sultan," Missionary Herald vol. 77 (January 1881): 35 .

39 Ellen Fleischmann, "Lost in Translation: Home Economics and the Sidon Girls' School of Lebanon, c. 1924-1932," Social Sciences and Mission 23 (2010): 32-62.

40 "Influence of American Missionaries on the Social Life of the East," Missionary Herald vol. 69 (June 1873): 187-19o.

41 Ibid.

42 Dennis, Christian Missions, 262. (From the report of Charles C. Tracy, missionary of Marsovan).

43 Dennis, Christian Missions, 459. (From the report of Rev. Dr J.L. Barton, missionary from Istanbul).

44 Ibid.

45 Dennis, Christian Missions, 265. (From the report of Charles C. Tracy of Marsovan): "It is safe to say that as the result of Christian missions great and blessed changes are apparent in thousands of homes." 


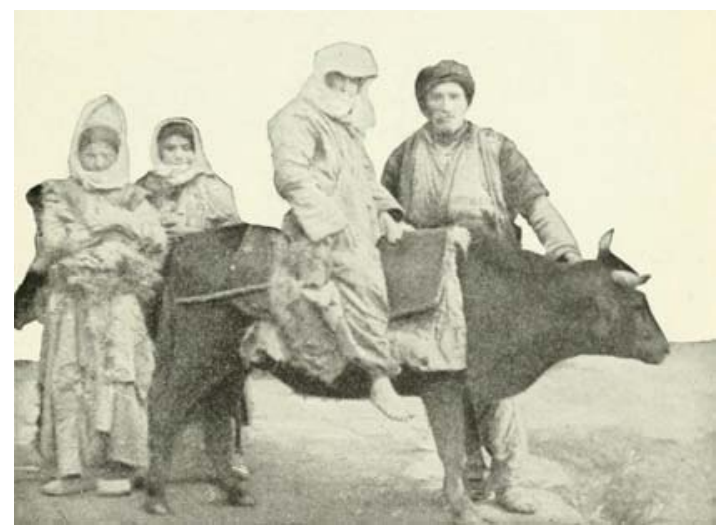

FIGURE 3.5 Village Armenians (before photograph).

Reproduced from Rev. George C. Reynolds, "For Young People: A Gospel Triumph in the Land of Ararat," Missionary Herald vol. 91 (May 1895): 212-216

It is a very conspicuous fact that where the Gospel has gained an entrance into a house or village, 'home' means much more than it did. There is a more intelligent outlook upon the world at large. The whole appearance of the house and family shows more cleanliness and neatness. ${ }^{46}$

Newly proselytized people and communities "immediately evince[d] a desire to change the sanitary conditions of their homes as well as their villages". ${ }^{47}$ It was reported that much greater "regard to the laws of health" in the arrangement of homes and in "attention to cleanliness of the person and of the household" was apparent. ${ }^{48}$ As a visual testimony of a "Gospel Triumph in the Land of Ararat", villagers from the Van region were photographed before and after adherence to the evangelical faith. The first picture depicted "the coarse and scanty clothing, the stolid faces, the use of the ox as a beast of burden (...) a few copper and earthen vessels in which to cook and eat their food, and some coarse carpets under which they might sleep at night on the ground" (Figure 3.5$) \cdot{ }^{49}$

46 Dennis, Christian Missions, 266. (From the report of Rev. John A. Ainslie of Mosul).

47 Dennis, Christian Missions, 459 .

48 Dennis, Christian Missions, 459. (Report of Dr G.C. Raynolds of Van).

49 Rev. George C. Reynolds, "For Young People: A Gospel Triumph in the Land of Ararat," Missionary Herald vol. 91 (May 1895): 212-216. 


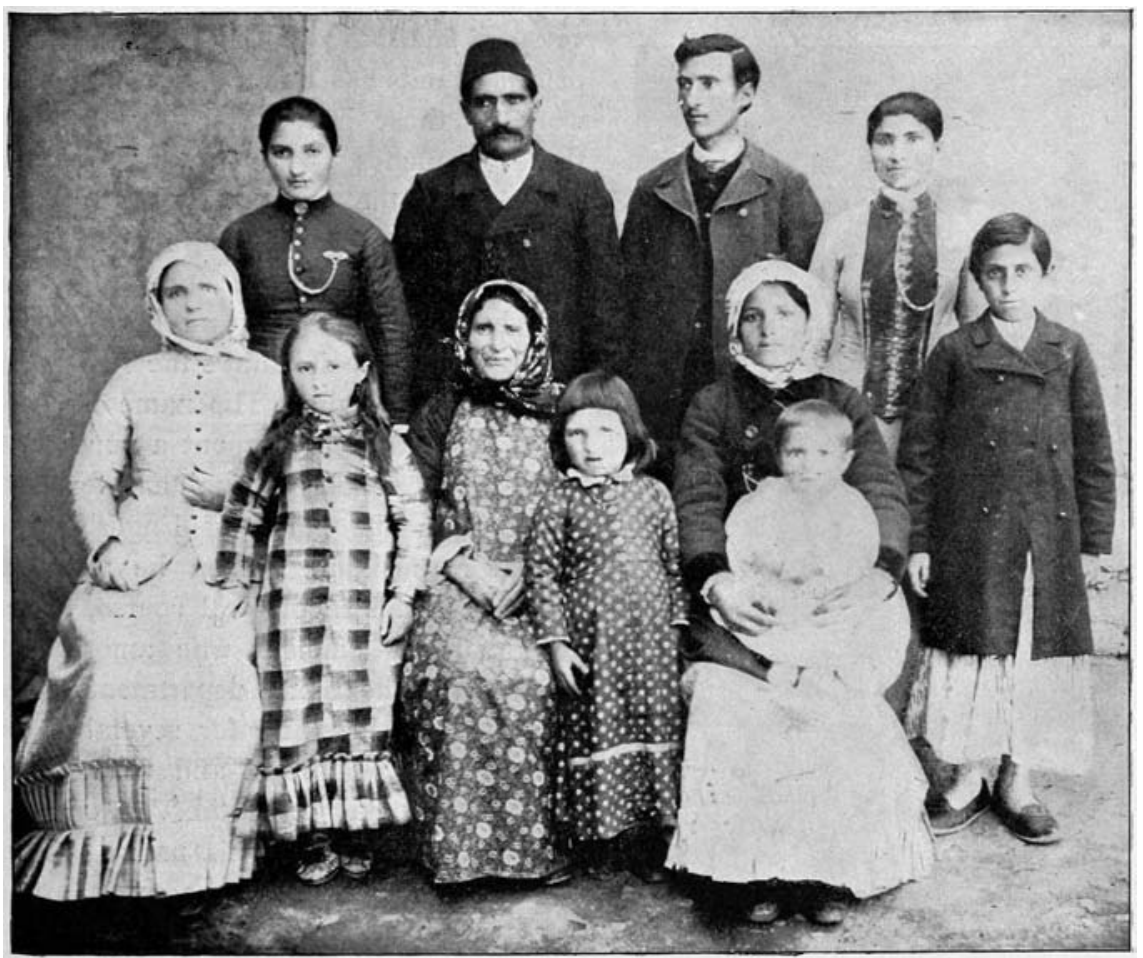

FIGURE 3.6 The family at Van (after photograph). Reproduced from Rev. George C. Reynolds, "For Young People: A Gospel Triumph in the Land of Ararat," Missionary Herald vol. 91 (May 1895): 212-216

The photo taken after twelve years of missionary work portrayed the "transforming gospel influences" on family life and "bear[ed] witness to missionary achievement" (Figure 3.6).50

The students in missionary schools and colleges were frequently used as examples of "best practices". They were following the new rules that they had been taught and were very important as transmitters of this knowledge and as pioneers and models for their communities. J.E. Pierce of Bardezag was sorry that he did not have the "before picture" of his students in the Armenian boys' school, but he was also confident that their "after photograph" would impress the readers of "For Young People". He also noted in a group photo of 


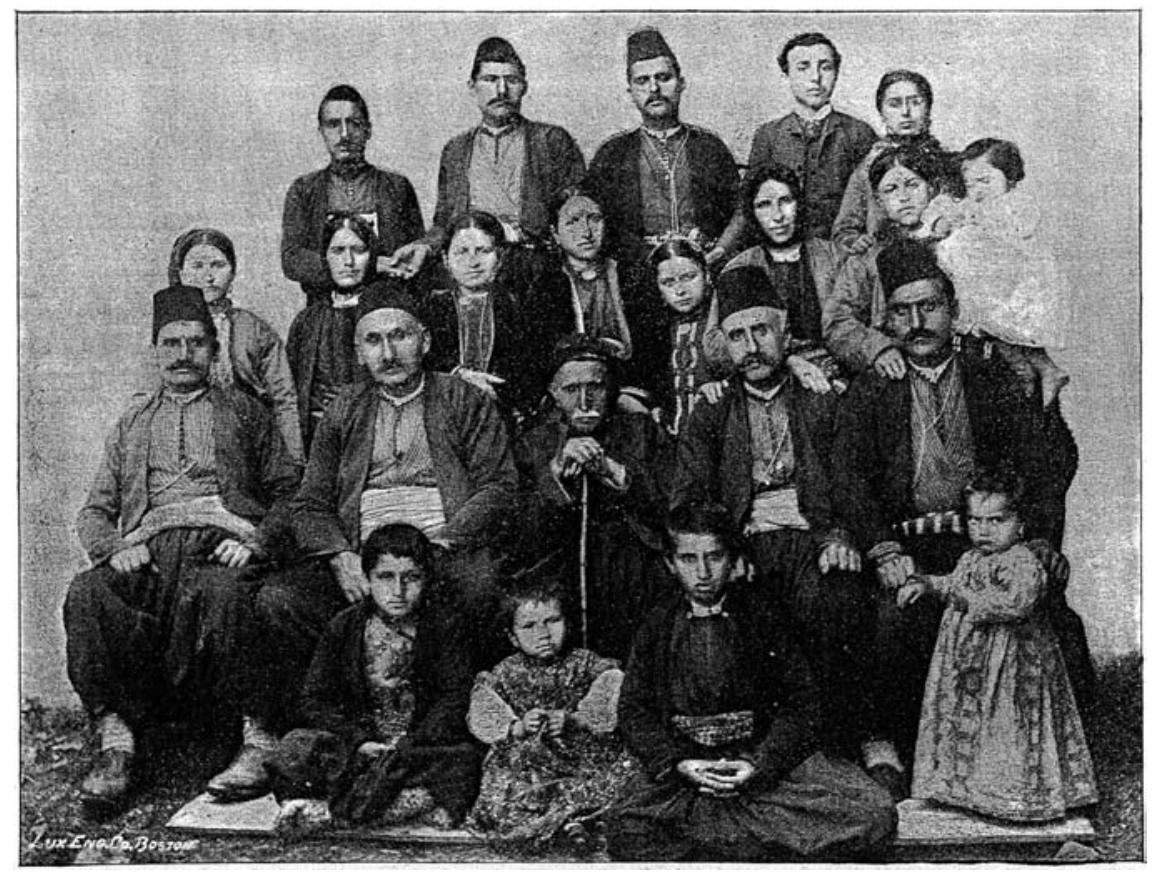

Figure 3.7 An Armenian family. Reproduced from J.E. Pierce, of Bardezag, "For Young People: Who Are the Armenians," Missionary Herald vol. 87 (April 1891): 175-178

an Armenian family that "one of the boys is a graduate of the Bardezag High School. You will have no difficulty in picking him up" (Figure $3 \cdot 7$ ). ${ }^{51}$

If you could only see the boys as they are when they first come to us, you would understand, at once, what a wonderful change Christian education brings, not only in thought and feeling, but in personal appearance as well. ${ }^{52}$ [Figure 3.8]

The body politics of the ABCFM missionaries also definitely had a gender aspect. They were convinced that the reforming of the family life, the emergence of a true "Christian home", and even the emergence of better phys-

$5^{1} \quad$ J.E. Pierce, of Bardezag, "For Young People: Who are the Armenians," Missionary Herald vol. 87 (April 1891): 175-178. (Italics mine). He is on the upper row, second on the right.

$5^{2}$ Ibid. (Italics mine). 


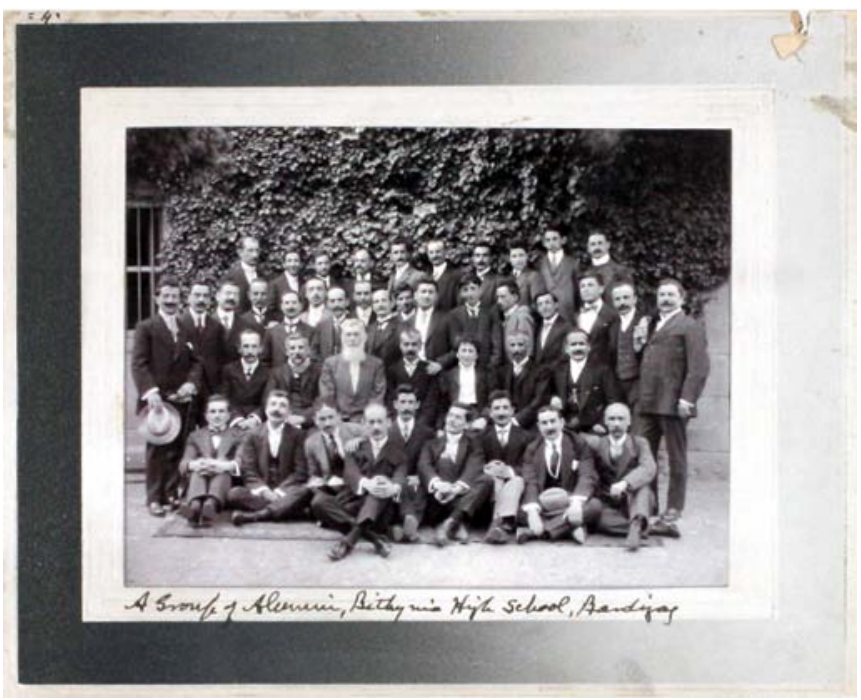

FIGURE 3.8 A group of Alumni, Bithynia High School, Bardizag. SALT Archives, American Board of Commissioners for Foreign Missions / Photographs /Bardizag, ABAHBARDoo9

ical surroundings was absolutely dependent on the missionary influences over women-either in the form of educating, "civilizing", or converting. ${ }^{53}$ The redressing of women's bodies was treated as a visible measure of progress, if not conversion. "Sleeping with day-time clothes", "not making any toilet" in the morning or "not paying attention to their own or their children's dressing or hair" were considered to be serious ills besetting to native women, and thus, should be cured. ${ }^{54}$ Women's authentic dresses and hairstyles often became topics of insult and humiliation. For instance, a certain form of headdress, common among the Greeks of the Black Sea area, was ridiculed because of its resemblance to a toothache covering.

53 Dana Lee Robert, American Women in Mission: A Social History of Their Thought and Practice (Macon: Mercer University Press, 1997); Lisa Joy Pruitt, A Looking-Glass for Ladies: American Protestant Women and the Orient in the Nineteenth Century (Macon: Mercer University Press, 2005); Ellen L. Fleischmann, “'Our Moslem Sisters': Women of Greater Syria in the Eyes of American Protestant Missionary Women," Islam \& Christian Muslim Relations 9 (1998): 307-323; K. Pelin Başç1, "Shadows in the Missionary Garden of Roses: Women of Turkey in American Missionary Texts," in Deconstructing Images of 'The Turkish Woman', ed. Zehra F. Arat (New York: St Martin's Press, 1998), 101-123.

"Influence of American Missionaries on the Social Life of the East." 


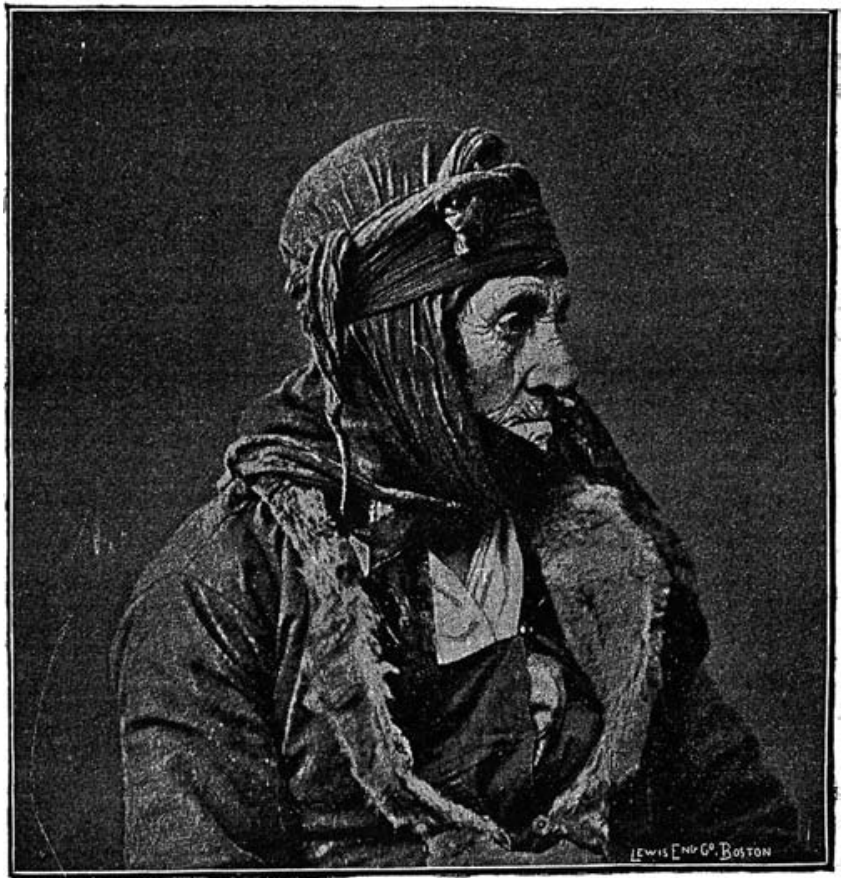

FIGURE 3.9 A Greek peasant woman. Reproduced from Rev. James W. Selye, of Constantinople, "For Young People: A Greek Town in Turkey," Missionary Herald vol. 85 (October 1889): 424-427

You notice the headdress peculiar to the Greek women of that region the arrangement of which impresses you constantly with the fear that they are suffering from chronic neuralgia or toothache. ${ }^{55}$ [Figure 3.9]

Women's conversion necessitated a radical transformation of the style of femininity. The introduction of evangelical Christianity in the communities could supposedly detected by the Western-style clothing and hairstyle that women adopted.$^{56}$ Women's bodies were targeted as a gender-conscious effort to civil-

55 Rev. James W. Selye, of Constantinople, "For Young People: A Greek Town in Turkey," Missionary Herald vol. 85 (October 1889): 424.

56 Inger Marie Okkenhaug, "Gender and Missions in the Middle East," Social Sciences and Missions 23 (2010): 1-6; Barbara Reeves-Ellington, Domestic Frontiers: Gender, Reform, and American Interventions in the Ottoman Balkans and the Near East (Amherst and Boston: University of Massachusetts Press, 2013); Norbert Friedrich, Uwe Kaminsky, and Roland 
ize and reshape them as symbols of domesticity in the home, as well as symbols of evangelical values in public. ${ }^{57}$

In sum, it was expected that the example and instruction of the missionaries in the field had a visible impact on the native communities, such that one could see the difference of those who were in contact with the Protestants. The "word of the Gospel" was supposed to transform not only beliefs but should be projected in the looks.

\section{$4 \quad$ Cure for Souls, Cure for Bodies}

In the second half of the 19th century, the rapprochement of spiritual conversion to bodily improvement found expression in the promotion of natural science. Shin K. Kim calls this form of Protestant Christianity as an "antiseptic religion". By the intermingling of American evangelical Christianity and the concept of hygiene (germ theory), there occurred a discourse of 'medicalized religion'. Most of the physicians within the American missionary corps were influenced by the germ theory of illness and considered Western medicine as an efficient tool to evangelize the country. Washing away sins from the soul became analogous to washing away germs from the body. 58

The ABCFM missionaries regarded the natural sciences, especially medicine, as part of their broader spiritual commitments. Although early medical activity by missionaries was usually a short-term, humanitarian response, medical activity soon encompassed an evangelistic strategy prompted by the sulky progress of conversion. There was an appreciation of the value of medical missionaries, especially in areas where mission's penetration was otherwise extremely difficult or where disease made their activity problematic. A postulate of medical missions was that curing patients gave legitimacy to the American mission-

Loffler, eds., The Social Dimension of Christian Missions in the Middle East: Historical Studies of the 1gth and 2oth Centuries (Stuttgart: Franz Steiner Verlag, 2010).

In her work on female missionary schools and physical education in the Ottoman Empire, Kahlenberg makes an analogous analysis. Caroline Kahlenberg, “'The Gospel of Health': American Missionaries and the Transformation of Ottoman/Turkish Women's Bodies, 189o-1932," Gender \& History 28, no. 1 (2016): 152.

$5^{8}$ Shin K. Kim, "An Antiseptic Religion: Discovering A Hybridity on the Flux of Hygiene and Christianity," Journal of Religion and Health 47 (2008): 253-262. 
aries' public work and greatly facilitated preaching. ${ }^{99}$ The ABCFM missionaries quickly discovered the indisputable usefulness of the medical services in breaking down opposition, dissipating prejudice and entering into the "hearts and homes of the high and the low, the rich and the poor".60 They underlined that health-related activities received the highest official recognition in the Ottoman Empire, and thus facilitated the working of all other branches, such as in the realms of education and preaching. Doctors were welcomed as persona grata even in the homes of the officials and state bureaus. Caring for the sick was a remarkable opportunity to spread the Protestant influence and better penetrate into the hosting communities. Therefore, the value of this department of the missions was considered to be exceptional especially at the early stages of establishing a mission station.

The mission stations had greater chances of communicating their religious teachings, when they were able to offer permanent health care facilities, such as infirmaries, hospitals, or asylums. Hospitals, in that respect, promised an open space, the rules of which were under missionary control such that the institution brought about different sorts of interpersonal relations. ${ }^{61}$ Medical missions were founded with the explicitly stated objective of entering into the hearts and minds of the people. In other words, people's bodies were utilized as gates to their beliefs, and betterment of their physical condition was interpreted as a sign of their religious enlightenment.

The advice and personal services of physicians were thought to facilitate the establishment of sanitary measures in hitherto neglected communities. The missionaries' presence equipped the converted Christians with an exceptional immunity during the prevalence of deadly visitations of diseases. The "testimonies" from various mission stations pointing to this "fact" were praised as explicit and material proofs of the gains the converts accrued by leading a Christian life. Dr Gates underlined that Protestants were not only cleaner in their homes and in their mode of living, but also had "less fear of death", saving them from the plague.

In time of cholera it has been noticed that the evangelical communities were to a marked degree free from the plague, so that in the region of Cili-

59 Philippe Bourmaud, "Public Space and Private Spheres: The Foundation of St Luke's Hospital of Nablus by the CMs (1891-19o1)," in New Faith in Ancient Lands: Western Missions in the Middle East in the Nineteenth and Early Twentieth Centuries, ed. Heleen Murre-van den Berg, SCM 32 (Leiden: Brill, 2006), 133-150.

6o Dennis, Christian Missions, 406.

61 Bourmaud, "Public Space and Private Spheres," 133. 
cia a Turkish official said: 'How is it, O ye Protestants; has God spread His tent over you that you are so spared?' I attribute this largely to the greater cleanliness and less fear of death prevailing among evangelical Christians. ${ }^{62}$

It may be truthfully said that the general health of the Protestants as a body has been greatly improved by their superior intelligence in regard to the laws of health, and by the attention which they have given to the sanitary condition of their homes. ${ }^{63}$

Medical work by American missionary physicians was, therefore, associated with the dissemination of Protestantism and the message of conversion. It was not only bodies that received attention in American missionary hospitals and clinics, but the souls as well. In that respect, the cure of souls went hand in hand with the cure of the diseases. ${ }^{64}$ Medical missions offered both a path to salvation and reformation of minds and daily habits. Daniel Bliss, who had joined the Syria mission station in 1855 and who served as the Syrian Protestant College President from 1866 to 1902, argued that healing and training in the medical arts and sciences offer one way to fulfill the promise of conversion: either through assuming the role of Christ in healing the body (and soul) and extracting somatic (and spiritual) evils or by striking at "degraded superstitions". 65

The ABCFM and the "Discourse of Civility"

Missionaries' history of the movement, together with certain histories of the missionary movement, have been particularly vulnerable to the accusation of cultural imperialism. As Makdisi underscored, "the remarkable similarity of

62 Dennis, Christian Missions, 465. (Report of Rev. Dr C.F. Gates of Harpoot). (Italics mine).

63 Dennis, Christian Missions, 465. (Report of Rev. J.K. Greene of Constantinople).

64 For more information on missions and medicine, see Rosemary Fitzgerald, "Clinical Christianity: The Emergence of Medical Work as a Missionary Strategy in Colonial India, 180o1914," in Health, Medicine and Empire: Perspectives on Colonial India, eds. Biswamoy Pati and Mark Harrison (New Delhi: Sangam Books, 2001); C. Peter Williams, "Healing and Evangelism: The Place of Medicine in Late Victorian Protestant Missionary Thinking," in The Church and Healing, ed. W.J. Sheils (Studies in Church Hist., xix, Oxford, 1982); Roy M. MacLeod and Milton James Lewis, eds., Disease, Medicine, and Empire: Perspectives on Western Medicine and the Experience of European Expansion (London: Routledge, 1988).

65 Cited in Elshakry, "The Gospel of Science," 178. 
writing on 'the' heathen and their routine denigration of foreign cultures and their determination to restructure them have made them an obvious target".66 It is apparent that the American Board adopted a resolute Puritan equation of its particular Christianity with civilization and paved the way for the reproduction of the discourse of the stagnant East, with its ignorant, unenlightened, non-White peoples.

Photography played a crucial role in the classification, conceptualization and visualization of "other" peoples. ${ }^{67}$ Even as late as the turn of the century, photographs were still imbued with the unencumbered spirit of the Enlightenment idea of "noble savage". ${ }^{68}$ Therefore, the discourse of educating and reforming the "heathens" by the "messengers of civilization and Christianity" was very strong. Although there were some infrequent tones of curiosity for indigenous forms of life, the American missionaries were more often judgmental in their evaluation of the peoples of the East. Most local customs and traditions were interpreted as evil and degenerate forms of religiosity and the cure was to introduce them to true Christianity.

Photographs usually preferred to exhibit different communal groups and/or tribes, costumes, and trades staged with primitivizing props, as ideas of clearly visible superiority developed by racist aspects of 19th-century evolutionary thinking shaped missionary attitudes towards different communities. ${ }^{69}$ In this respect, ABCFM missionaries' line of thinking was shaped with such "progressivist" tendencies that societies and peoples would eventually (or sometimes with outside intervention) progress from a backward state of existence to modernity, from barbarism to civility. Thus, different religious and linguistic communities in Anatolia were assumed to be at earlier stages of a teleological march toward "civilization". From within this ideological framework, the function and value of the photographs of Orthodox Christians who converted to Protestantism with the preaching of ABCFM missionaries was primarily attached to their meaning as documents of progress as a historical process. $^{70}$ Therefore, photography, within the context of cultural criticism, was

66 Ussama Makdisi, Artillery of Heaven: American Missionaries and the Failed Conversion of the Middle East (Ithaca: Cornell University Press, 2008), 9.

67 Reina Lewis, Rethinking Orientalism: Women, Travel and the Ottoman Harem (New Brunswick, NJ: Rutgers University Press, 2004), 209.

68 Behdad notes that since its very inception, photography was intertwined with Europe's Orientalist vision of the Middle East. Ali Behdad, "The Power-ful Art of Qajar Photography: Orientalism and (Self)-Orientalizing in Nineteenth Century Iran," Iranian Studies 34, nos. 1-4 (2001): 141-151.

69 Erdogdu, "Picturing Alterity," 119.

70 Photography featured as an important tool in furnishing the Orientalist system of know- 
also instrumental for disciplinary purposes: it was a record of the converted subjects. ${ }^{71}$ The images or imagery produced a dynamic rhetoric of cultural and ethnographic difference between evangelical Protestants and non-Christian "peoples" and "places". ${ }^{72}$

The logic behind the usage of visual material was, without a doubt, to illustrate how miracles came true by evangelicalism. Western styles of dress, physical decorum and hygiene were treated as signifiers of Protestant faith, piety, and virtue that native peoples came to embrace. American Board missionaries perceived the various forms of Orthodox Christianity as "nominal Christians", as Christians only in name but not in practice. Through contact with the ABCFM missionaries, "nominal" or "professing" Christians would find not only religious guidance but also move forward along the evolutionary path to "civility". Civilizing "native peoples" was possible by teaching them how to read - to be saved from the ignorance of illiteracy, by furnishing them with a talent - to gain their own honorable livelihood, and by leading them to genuine Christian way - to get rid of nominal/schismatic Christianity in a gradual fashion. ${ }^{73}$

As I argued throughout the article, since the spiritual state of existence was invisible, conversion was practically reduced to retouchings in the material state of existence. The ABCFM missionaries used visual representations, photography and narrative descriptions as evidence of successful proselytization. They referred to bodily and physical conditions as material representations and mirrors of the religious and moral state of people. New forms of clothing, Western-style hairdressing, altered postures and looks, and also the use of the English language - all these were interpreted as signifiers to measure the extent of dissemination of Christian belief among native people. As tan-

ledge with an efficient and empirical way for gathering data. Ali Behdad, "Sevruguin: Orientalist or Orienteur?" in Sevruguin and the Persian Image: Photographs of Iran, 1870-1930, ed. Frederick N. Bohrer (Washington: Smithsonian Institution, 1999), 79-98.

71 Mary Roberts, Intimate Outsiders: The Harem in Ottoman and Orientalist Art and Literature (Durham: Duke University Press, 2007), 176.

72 Sheehi discusses the linkage between the consolidation of a bourgeois identity and photography. Stephen Sheehi, "A Social History of Early Arab Photography or a Prolegomenon to an Archaeology of the Lebanese Imago," IJMES 39 (2007): 177-208.

73 In her work on Scandinavian and German missions in Anatolia (among Armenians), Okkenhaug underlines that the Scandinavian missionaries frequently repeated that they do not want to turn Armenians into "Germans" - meaning Protestants — but to create "living Christians", which might be interpreted as a reformation within the Armenian Church, Inger Marie Okkenhaug, "Women on a Mission! Scandinavian Welfare and the Armenians in the Ottoman Empire, 1905-1917," in Interpreting Welfare and Relief in the Middle East, eds. Nefissa Naguib and Inger Marie Okkenhaug (Leiden: Brill, 2008). 
gible proofs and easily malleable targets, refashioning bodies and places were part of the American missionary agenda in their general aspirations to evangelize. Given the difficulty in providing evidence of conversion, these material and physical transformations were solid outcomes of their efforts and promotable results of missionary work. Metamorphosis from "nominal", so false to true Christianity was merely "a process of self-fashioning modeled by the dictates of the missionaries". ${ }^{74}$

\section{Bibliography}

\section{ABCFM Reports and Publications}

"Influence of American Missionaries on the Social Life of the East." Missionary Herald vol. 69 (June 1873): 187-19o.

"For Young People: The Empire of the Sultan." Missionary Herald vol. 77 (January 1881): 33-39.

Mission Stories of Many Lands: A Book for Young People. Boston: The ABC FM, 1885.

Herrick, Rev. George F. "Canon Taylor on Missionary Methods." Missionary Herald vol. 85 (January 1889).

Selye, Rev. James W. of Constantinople. "For Young People: A Greek Town in Turkey." Missionary Herald vol. 85 (October 1889): 424-427.

Pierce, J.E. of Bardezag. "For Young People: Who are the Armenians." Missionary Herald vol. 87 (April 1891): 175-178.

Reynolds, Rev. George C. "For Young People: A Gospel Triumph in the Land of Ararat.” Missionary Herald vol. 91 (May 1895): 212-216.

"Fifty Thousand Orphans made so by the Turkish Massacres of Armenians." New York Times, December 18, 1896.

"Merzifon Station Report, 1897." ABC 16.9.3, reel 6o6, nos. 698-670.

Nason, Miss. "Work for Orphans." Missionary Herald vol. 93 (March 1897): 112-113.

"Editorial Paragraphs." Missionary Herald vol. 93 (June 1987).

In Lands Afar: A Second Series of Mission Stories of Many Lands, A Bookfor Young People. Boston: ABCFM, 1897.

"Mardin Orphanage, Reports for 1897-1899." ABC 16.5, reel 512, nos. 201-230.

"For Young People: Orphans in Turkey." Missionary Herald vol. 94 (May 1898): 204-208.

"Editorial Paragraphs." Missionary Herald vol. 95 (October 1899).

Dennis, Rev. James S. Christian Missions and Social Progress: A Sociological Study of Foreign Missions. New York: Fleming H. Revell Company, 1899.

74 Williams, Framing the West, 92. 
White, George E. “Annual Report of Merzifon Station 1905-1906." SALt Archives, American Board of Commissioners for Foreign Missions, ABAAS Rooo313, https://archives .saltresearch.org/handle/123456789/46791.

\section{Secondary Literature}

Alloula, Malek. The Colonial Harem. Minneapolis, Minn.: University of Minnesota, 1986.

Anderson, Margaret Lavinia. “'Down in Turkey, Far Away': Human Rights, the Armenian Massacres, and Orientalism in Wilhelmine Germany." The Journal of Modern History 79 (2007): 8o-111.

Badr, Habib. "American Protestant Missionary Beginnings in Beirut and Istanbul: Policy, Politics, Practice and Response." In New Faith in Ancient Lands: Western Missions in the Middle East in the Nineteenth and Early Twentieth Centuries, edited by Heleen Murre-van den Berg, 211-240. SCM 32. Leiden: Brill, 2006.

Başçı, K. Pelin. "Shadows in the Missionary Garden of Roses: Women of Turkey in American Missionary Texts." In Deconstructing Images of 'The Turkish Woman', edited by Zehra F. Arat, 101-123. New York: St Martin's Press, 1998.

Behdad, Ali. "Sevruguin: Orientalist or Orienteur?" In Sevruguin and the Persian Image: Photographs of Iran, 1870-1930, edited by Frederick N. Bohrer, 79-98. Washington: Smithsonian Institution, 1999.

Behdad, Ali. "The Power-ful Art of Qajar Photography: Orientalism and (Self)-Orientalizing in Nineteenth Century Iran." Iranian Studies vol. 34, nos. 1-4 (2001): 141-151.

Bourmaud, Philippe. "Public Space and Private Spheres: The Foundation of St Luke's Hospital of Nablus by the CMs (1891-1901)." In New Faith in Ancient Lands: Western Missions in the Middle East in the Nineteenth and Early Twentieth Centuries, edited by Heleen Murre-van den Berg, 133-150. SCM 32. Leiden: Brill, 2006.

Çizgen, Engin. Photography in the Ottoman Empire. Istanbul: Haşet Kitabevi, 1987.

Deringil, Selim. “'The Armenian Question is Finally Closed': Mass Conversions of Armenians in Anatolia during the Hamidian Massacres of 1895-1897." Comparative Studies in Society and History 51 (2009): 344-371.

Elshakry, Marwa. "The Gospel of Science and American Evangelism in Late Ottoman Beirut." Past and Present 196, no. 1 (2007): 173-214.

Erdogdu, Ayshe. "Picturing Alterity: Representational Strategies in Victorian Type Photographs of Ottoman Men." In Colonialist Photography:Imag(in)ing Race and Place, edited by Eleanor M. Hight and Gary D. Sampson, 1107-1125. London: Routledge, 2004.

Fitzgerald, Rosemary. "Clinical Christianity: The Emergence of Medical Work as a Missionary Strategy in Colonial India, 180o-1914." In Health, Medicine and Empire: Perspectives on Colonial India, edited by Biswamoy Pati and Mark Harrison. New Delhi: Sangam Books, 2001. 
Fleischmann, Ellen L. “'Our Moslem Sisters': Women of Greater Syria in the Eyes of American Protestant Missionary Women." Islam \& Christian Muslim Relations 9 (1998): 307-323.

Fleischmann, Ellen. "Evangelization or Education: American Protestant Missionaries, the American Board, and the Girls and Women of Syria (1830-1910)." In New Faith in Ancient Lands: Western Missions in the Middle East in the Nineteenth and Early Twentieth Centuries, edited by Heleen Murre-van den Berg, 263-28o. sсм 32. Leiden: Brill, 2006.

Fleischmann, Ellen. "Lost in Translation: Home Economics and the Sidon Girls' School of Lebanon, c. 1924-1932." Social Sciences and Mission 23 (2010): 32-62.

Friedrich, Norbert, Uwe Kaminsky, and Roland Loffler, eds. The Social Dimension of Christian Missions in the Middle East: Historical Studies of the 19th and 20 th Centuries. Stuttgart: Franz Steiner Verlag, 2010.

Hight, Eleanor M., and Gary D. Sampson, eds. Colonialist Photography: Imag(in)ing Race and Place. London: Routledge, 2004.

Kahlenberg, Caroline. “'The Gospel of Health': American Missionaries and the Transformation of Ottoman/Turkish Women's Bodies, 189o-1932." Gender \& History 28, no. 1 (2016): 150-176.

Kieser, Hans-Lukas. Derverpasste Friede. Mission, Ethnie und Staat in den Ostprovinzen der Türkei 1839-1938. Zurich: Chronos Verlag, 2000.

Kieser, Hans-Lukas. "Mission as Factor of Change in Turkey (Nineteenth to First Half of Twentieth century)." Islam and Christian-Muslim Relations 13 (2002): 391-410.

Kim, Shin K. "An Antiseptic Religion: Discovering A Hybridity on the Flux of Hygiene and Christianity." Journal of Religion and Health 47 (2008): 253-262.

Lalvani, Suren. Photography, Vision, and the Production of Modern Bodies. Albany, N.Y.: State University of New York Press, 1996.

Landau, Jacob M. Exploring Ottoman and Turkish History. London: Hurst \& Co., 2004.

Lawson, Barbara. "Collecting Cultures: Canadian Missionaries, Pacific Islanders, and Museums." In Canadian Missionaries, Indigenous Peoples: Representing Religion at Home and Abroad, edited by Alvyn Austin and Jamie S. Scott, 235-261. Toronto: University of Toronto Press, 2005 .

Lemke, Wolf-Deiter. "Ottoman Photography: Recording and Contributing to Modernity." In The Empire in the City: Arab Provincial Capitals in the Late Ottoman Empire, edited by Jens Hanssen, Thomas Philipp, and Stefan Weber. Beirut: Ergon Verlag Würzburg, 2002.

Lewis, Reina. Rethinking Orientalism: Women, Travel and the Ottoman Harem. New Brunswick, NJ: Rutgers University Press, 2004.

Löffler, Roland. "The Metamorphosis of a Pietistic Missionary and Educational Institution into a Social Services Enterprise: The Case of the Syrian Orphanage (186o1945)." In New Faith in Ancient Lands: Western Missions in the Middle East in the 
Nineteenth and Early Twentieth Centuries, edited by Heleen Murre-van den Berg, 151174. SCM 32. Leiden: Brill, 2006.

MacLeod, Roy M., and Milton James Lewis, eds. Disease, Medicine, and Empire: Perspectives on Western Medicine and the Experience of European Expansion. London: Routledge, 1988.

Makdisi, Ussama. The Culture of Sectarianism: Community, History, and Violence in Nineteenth-Century Ottoman Lebanon. Berkeley: University of California Press, 2000.

Makdisi, Ussama. Artillery of Heaven: American Missionaries and the Failed Conversion of the Middle East. Ithaca: Cornell University Press, 2008.

Maksudyan, Nazan. "'Being Saved to Serve': Armenian Orphans of 1894-96 and Interested Relief in Missionary Orphanages." Turcica 42 (2010): 47-88.

Merguerian, Barbara J. "Saving Souls or Cultivating Minds? Missionary Crosby H. Wheeler in Kharpert, Turkey." Journal of the Society for Armenian Studies 6 (19921993):33-6o.

Merguerian, Barbara J. “'Missions in Eden': Shaping an Educational and Social Program for the Armenians in Eastern Turkey (1855-1895)." In New Faith in Ancient Lands: Western Missions in the Middle East in the Nineteenth and Early Twentieth Centuries, edited by Heleen Murre-van den Berg, 241-262. Sсм 32. Leiden: Brill, 2006.

Okkenhaug, Inger Marie. "Women on a Mission! Scandinavian Welfare and the Armenians in the Ottoman Empire, 1905-1917." In Interpreting Welfare and Relief in the Middle East, edited by N. Naguib and Inger Marie Okkenhaug. Leiden: Brill, 2008.

Okkenhaug, Inger Marie. "Gender and Missions in the Middle East." Social Sciences and Missions 23 (2010): 1-6.

Prochaska, David. "Archive of l'Algerie Imaginaire." History and Anthropology 4 (1990): 373-420.

Pruitt, Lisa Joy. A Looking-Glass for Ladies: American Protestant Women and the Orient in the Nineteenth Century. Macon: Mercer University Press, 2005.

Reeves-Ellington, Barbara. Domestic Frontiers: Gender, Reform, and American Interventions in the Ottoman Balkans and the Near East. Amherst and Boston: University of Massachusetts Press, 2013.

Robert, Dana Lee. American Women in Mission: A Social History of Their Thought and Practice. Macon: Mercer University Press, 1997.

Roberts, Mary. Intimate Outsiders: The Harem in Ottoman and Orientalist Art and Literature. Durham: Duke University Press, 2007.

Sheehi, Stephen. "A Social History of Early Arab Photography or a Prolegomenon to an Archaeology of the Lebanese Imago." IJMES 39 (2007): 177-208.

Veer, Peter van der, ed. Conversion to Modernities: The Globalization of Christianity. New York: Routledge, 1996.

Williams, C. Peter. "Healing and Evangelism: The Place of Medicine in Late Victorian 
Protestant Missionary Thinking." In The Church and Healing, edited by W.J. Sheils. Studies in Church History 19. Oxford, 1982.

Williams, Carol. Framing the West: Race, Gender, and the Photographic Frontier in the Pacific Northwest. Oxford: Oxford University Press, 2003. 


\title{
Spiritual Reformation and Engagement with the World: Scandinavian Mission, Humanitarianism, and Armenians in the Ottoman Empire, 19०5-1914
}

\author{
Inger Marie Okkenhaug
}

\section{Introduction}

I had never earlier seen as many poorly and pitiably ill people as I did in Mus [sic] and the surrounding villages. There were only two doctors for the population of the whole area, a military doctor and the district physician, both Turks. ${ }^{1}$

These are the words of missionary and nurse, Bodil Biørn (1871-196o), describing her first encounter with the Musch region in eastern Anatolia in October 1907. In an attempt to make Norwegian supporters and sponsors identify with the plight of Armenian mountain people in eastern Anatolia, Biørn described their food. The bread reminded her of the barkebrød (bark bread) Norwegians survived on during a period of hunger during the Napoleonic wars. ${ }^{2}$ During the hundred years that had passed since the Norwegians suffered the consequences of European wars in the early 180os until 1907, Norway had become an independent state, which demonstrated early signs of a modern health system. The first professional nursing training school, for example, the deaconess institution Lovisenberg in Christiania (Oslo), was established in 1868. Before leaving for the Ottoman Empire as a missionary, Biørn was a student at Lovisenberg and she later worked as a nurse in Norway for several years. Upon hearing about the plight of Armenian orphans, Biørn experienced a personal calling to work among the Armenians as a missionary and nurse. In 1905 she arrived in Turkey in order to work for a small organization, the Women Mission Workers ("Kvinnelige misjonsarbeidere": KMA). Here Biørn became part of a transnational network that engaged in humanitarian work among the Armenian population, and later with Armenian refugees in the years during and after World War I.

1 National Archives, KMA, PA 699, nr. о028, KMA Kvartalshilsen nr. 2 (1908), 16.

2 Henrik Ibsen wrote a poem about this hunger called "Terje Vigen”. 
The KMA was the first independent women's mission organization in Scandinavia. Inspired by the international holiness movement and the English Keswick Conventions, the KMA's first branch was established in Sweden in 1894, then in Denmark and Finland in 1900, and in Norway in 1902. ${ }^{3}$ Missionaries and members belonged to the upper and upper middle classes, and they were educated women - many worked as teachers and nurses. The idea behind the KMA was not to create a support association for already established mission organizations, but to establish a prayer-movement by and for women. It was thus a mobilizing force for women's right to take spiritual responsibility for their own lives, as noted by theologian Kristin Norseth. ${ }^{4}$ As such, the KMA was a realization of women's strong desire for direct and practical participation in mission work on their own terms. ${ }^{5}$ For many KMA-missionaries practical mission work involved humanitarian engagements, as well as evangelization. Humanitarian work was an integral part of the missionary enterprise of other groups, such as the American Protestant missionaries who worked in Armenian communities in the Ottoman Empire. ${ }^{6}$ This fusion of evangelization, emergency relief, and "longer-term efforts to prevent suffering from famine, illhealth, or poverty"7 that characterized other missionary efforts in the area, also described the approach and activities of the Scandinavian KMA missionaries in the Middle East.

Based on sources from the Danish, Swedish, and Norwegian branches of the KMA, this article focuses on how the mission-evangelization, healing, and

3 The Holiness movement, originating in the 19th century among Protestant churches in the United States, was inspired by J. Wesley's and the Methodist teaching of human existence without sin. Inspired by the Holiness movement in Keswick, England, from 1875 on, several thousand evangelicals gathered for annual conventions focusing on Christians spiritual empowerment to overcome a sinful life. "Hellighetsbevegelsen," Store Norske Leksikon, accessed September 20, 2018, https://snl.no/hellighetsbevegelsen.

4 Kristin Norseth, "La os bryte over tvert med vor stumhet: kvinners vei til myndighet i de kristelige organisasjonene 1842-1912" (PhD diss., University of Oslo, 2007), 402. Influenced by women's mission organizations in North America, Great Britain, and Germany at the time, these women wanted to realize their God-given calling to serve God in mission work at home or abroad.

5 Norseth, "La os bryte over tvert med vor stumhet," 402.

6 Flora A. Keshgegian, "'Starving Armenians': The Politics and Ideology of Humanitarian Aid in the First Decades of the Twentieth Century," in Humanitarianism and Suffering: The Mobilization of Empathy, eds. Richard Ashby Wilson and Richard D. Brown (Cambridge: Cambridge University Press, 2008), 144. See also Nazan Maksudyan's article in this volume.

7 Johannes Paulmann, "Conjunctures in the History of International Humanitarian Aid during the Twentieth Century," Humanity 4, no. 2 (Summer 2013): 215, http://humanityjournal.org/wp -content/uploads/2014/06/4.2-Conjunctures-in-the-History-of-International-HumanitarianAid-during-the-Twentieth-Century.pdf. 
welfare - was practiced by a Scandinavian female missionary working for the pietistic, German "Deutscher Hülfsbund für Christliche Liebeswerk im Orient", in the Ottoman Empire from 1905 to 1914. A central issue for the Scandinavian Women's Mission Workers was the plight of girls and women. In Protestant mission ideology and rhetoric in general, Non-Christian women were to be included in what was perceived as the collective of Christian, liberated women. This was a result of the Evangelical belief in all women's right to salvation and the corresponding spiritual equality of men and women. How did Biørn include local women's plight in her vocation? What resonance did the Protestant emphasis on women's work for women have in Armenian society?

Protestant missionaries created and operated in transnational spaces, on both social and ideational levels. These transnational arenas were characterized by a variety of local and foreign actors. As argued by historian Julia Hauser, the actors competed, cooperated, and appropriated each other's approaches, or were connected by virtue of the mobility of students and teachers between establishments. In her study of the German Kaiserswerth Deaconesses in Beirut, Hauser shows how the missionary agenda - being fundamentally impacted by local factors - underwent considerable transformation in practice. ${ }^{8} \mathrm{How}$ was the KMA agenda of evangelization, healing, and welfare impacted by local factors in Turkish Armenian societies? How was this humanitarian and spiritual work received by local parties?

When Biørn left Norway in 1905, the KMA gave her a camera. She was to take pictures that, together with her written reports from the field, would document the work in which Scandinavian supporters invested prayers and money. The photos taken from Armenian communities in eastern Anatolia (the Musch region) provide invaluable visual documentation of a society extinguished by genocide in 1915. Biørn's photographs are now held in the Norwegian National Archives in Oslo and accessible on Wikimedia. ${ }^{9}$

In addition to the photographs, the letters and reports written by Biørn and her Swedish colleague, the nurse and midwife Alma Johansson (1880-1974), are important sources that describe life in the Musch region, where the pre-World

8 Julia Hauser, "From Transformation to Negation: A Female Mission in a 'City of Schools," Journal of World History 27, no. 3 (September 2016): 476-477.

9 "Skolepiker fra Musch, lærerinnen og Bodil Biørn," Wikimedia, made available by the National Archives of Norway, https://commons.wikimedia.org/wiki/Category:Bodil_Bi\%C $3 \% B 8 \mathrm{rn}$. 
War I population consisted of Kurds, Armenians, and Turks. ${ }^{10}$ Furthermore, there are published reports and unpublished letters from the Danish KMA's work among Armenians in the Anatolian twin cities, Kharpert and Mezereh.

\section{3}

\section{Bodil Biørn: Background}

Bodil Biørn, who came from a wealthy shipping family, grew up in Kragerøa coastal town in the south of Norway. Growing up with a loving and deeply religious, German Lutheran, mother, Biørn held a profound Protestant conviction, with a strong inclination to serve both spiritually and physically. ${ }^{11}$ Despite her upper-class background Biørn chose a life of work, inspired by her religious calling which led her to the nursing profession. At the time nursing was one of the few professions open to women in Norway.

In the late 19th century Norwegian society underwent a dramatic process of modernization, in which industry, migration, and urbanization were key factors. Even so, the society was still to a large extent rural, traditional, and patriarchal: expectations regarding gender did not change much from the norms of preindustrial, agrarian Norway. The ideal was to stay at home and take care of husband and children. According to historian Elisabeth Lønnå, "working women (mostly unmarried) were systematically paid less than men and kept out of leading positions within their field of work ... The great majority were kept in totally subordinate positions as [house] servants, a type of work most men were able to avoid". 12

Being a deacon was an alternative profession to working as a house servant. Those who chose this rigorous and demanding training, which demanded the candidates' total submission, were mostly women from the lower classes. ${ }^{13}$ Biørn's upper-class background made her an exception. Even though she was born into privilege she chose to follow her personal calling to enter the deaconess training at Lovisenberg in Christiania. Biørn's religious calling was closely tied to the notion of healing and caring for people in need. Spiritual vocation

10 There are also German missionary sources from Musch, but so far these sources from the Deutscher Hülfsbund have not been examined systematically in scholarly works.

11 Inger Marie Okkenhaug, "En norsk filantrop": Bodil Biørn og armenerne, 1905-1934 (Kristiansand: Portal forlag, 2016).

12 Elisabeth Lønnå, "Gender in Norway in the Period of Mass Emigration," in Norwegian American Women: Migration, Communities and Identities, eds. Betty A. Bergland and Lori Ann Lahlum (St Paul: Minnesota Historical press, 2011), 40.

13 Kari Martinsen, Freidige og uforsakte diakonisser: et omsorgsyrke vokser fram, 1860-1905 (Oslo: Aschehoug/Tanum-Norli, 1984). 
and humanitarian relief were also interconnected in Biørn's decision to leave Norway in order to work among persecuted Armenians in the Ottoman Empire.

\section{The Abdülhamid II Massacres, Missions, and Relief}

The Armenians - two million in number - were one of the largest Christian minorities in the Ottoman Empire. The majority belonged to the Armenian Apostolic Church, though there were also Catholic and Protestant minorities. Before World War I, there were particular Armenian concentrations - though never demographic majorities except at local levels - in the historic Armenian settlements. The most significant ones were in the eastern provinces of Anatolia, where they date back 3,00o years. ${ }^{14}$ These were the regions in which Protestant, including Scandinavian, missionaries settled.

From 1894 to 1896 , the Armenians in Anatolia suffered widespread persecutions initiated by the Ottoman government. During the Abdülhamid II massacres, Armenian villages were plundered and in many places in Anatolia, there were absolutely no resources left to start cultivating the land. ${ }^{15}$ It is estimated that out of the 2 million Armenians, more than 88,ooo were murdered; 500,000 were robbed of all their belongings; around 2,500 villages and towns were plundered; 568 churches were pillaged and destroyed; and 282 churches were turned into mosques. ${ }^{16}$ Finally, 100,00o orphans and widows were without support. ${ }^{17}$ The massacres had left Armenian communities without their traditional networks of family, kin, and church. Since men had been the main targets of the massacres, women had to become breadwinners and heads of families.

The massacres received great attention in the USA and Europe, including the Scandinavian countries. The massacres, according to historian Matthias Bjørnlund, were the main impetus that transformed the Danish KMA from a Bible Study group to an effective missionary NGO. ${ }^{18}$ The Danes' eagerness to

\footnotetext{
14 Razmik Panossian, The Armenians: From Kings and Priests to Merchants and Commissars (New York: Columbia University Press, 2006), 42, 84-85.

15 National Archive (Rigsarkivet), Copenhagen, KMA.36o, pk. nr. 16. Letter from Christa Hammer, January 19, 1902.

16 Julius Richter, History of Protestant Missions in the Near East (London: Fleming H. Revell Company, 1910), 143 .

17 Ernst Lohmann, Skildringer af Armeniske Forhold og Tilstande (Copenhagen, 1902), 11. Translated from German to Danish.

18 Matthias Bjørnlund, "Harput-Missionaries, Danish Missionaries in the Kharpert Province: A Brief Introduction," Houshamadyan, accessed May 23, 2018, http://www.houshamady an.org/mapottomanempire/vilayetofmamuratulazizharput/harputkaza/religion/missio naries.html.
} 
contribute to relief among persecuted Armenians had repercussions in Norway. In February 1904, a representative from the Danish KMA was invited by the KMA in Christiania, to speak about the Armenian massacres and the great need for humanitarian assistance that still existed. The Danish and Swedish KMA had several nurses working with relief in Anatolia, and now the Norwegian KMA wanted to send out a nurse as well. Bodil Biørn attended the meeting. She was deeply moved by the plight of Armenian children. To her it seemed like God had given her a mission to help relieve suffering among Armenian orphans. Biørn became the KMAs envoy to the Armenians. They would pay her wages, although she formally worked for the Deutscher Hülfsbund. After a year of training at the KMA School for female missionaries in Copenhagen, and a three-week training course with the Deutscher Hülfsbund in Freienwalde, Germany, Biørn was initiated as missionary and left for Turkey in the fall of 1905.

\section{5}

\section{Transnational Mission Work in the Ottoman Empire}

The various independent womens' mission organizations in Norway, and the rest of Scandinavia, were small in numbers and they relied on financial, practical, and ideological cooperation with each other. In the Ottoman Empire they also relied on cooperation with the Deutscher Hülfsbund, the Deutsche Orient Mission, and the American Board of Commissioners for Foreign Mission (ABCFM) ${ }^{19}$ This was practical: the KMA was too small to establish their own mission stations. Being an all-women organization, it was also seen as unsafe to establish mission stations in the Middle East without Western male missionaries. $^{20}$

Safety considerations and the need for infrastructure, in addition to the wellestablished connections with German and American missions, led the Danish

19 Matthias Bjørnlund, "A Fate Worse than Dying: Sexual Violence during the Armenian Genocide," in Brutality and Desire: War and Sexuality in Europe's Twentieth Century, ed. Dagmar Herzog (Basingstoke: Palgrave, 20o9), 148.

20 Not until 1919 was a women given formal status as missionary by the dominating Norwegian mission society (Det Norske Misjonsselskap NMS). Almost twenty years earlier, prominent religious women had established KMA, an organization that would enable them to be directly involved in, and have control over mission work both at home and abroad. See Line Nyhagen Predelli, "Emma Dahl: Contesting the Patriarchal Gender Regime of the Norwegian Missionary Society in Madagascar," Scandinavian Journal of History 2 (2003): 105-106, 120; Inger Marie Okkenhaug, "Herren har givet mig et rigt virkefelt: Kall, religion og arbeid blant armenere i Det osmanske riket," ("Vocation, Religion and Work Among Armenians in the Ottoman Empire") Historisk Tidsskrift (Journal of History) 1 (2009): 396 o. 
KMA to start an orphanage, Emaus [Emmaus], in Mezreh (present-day Elazig) in 1902. This institution was Scandinavian in the sense that it received support from the Nordic countries, and its initial staff consisted of the first Scandinavian missionaries in Turkey: the Danish Christa Hammer (d. 1903) and the earlier mentioned Swedish Alma Johansson. ${ }^{21}$ In the beginning, the Ottoman authorities were hostile towards the Scandinavian establishment, but a few months after the opening, Hammer observed that the local authorities, the Vali, had a positive view of the mission's health work. ${ }^{22}$

Christa Hammer and Alma Johansson were both linked to the Deutscher Hülfsbund, while another of the early Danish KMA missionaries, the nurse Maria Jacobsen (1882-1960), worked as head nurse for the American Boardthe largest Protestant mission in the Middle East before World War I, present in Mezreh and Kharpert since 1907. These links between the Scandinavian кмA missions and the American Board and the Deutscher Hülfsbund, illustrate how these organizations developed entangled histories, creating transnational networks and transnational spaces in the Middle East. ${ }^{23}$ When Biørn arrived in Turkey in 1905, the headquarters of Deutscher Hülfsbund stationed her in Mezreh. Here she worked as a nurse in the German orphanage Elim, headed by the Dane Jenny Jensen, from the KMA. ${ }^{24}$ Biørn, at the same time, also worked in the American Board hospital in Mezreh. This was a typical first year experience for the KMA-missionaries. They had to have a "workingknowledge" of English and German, and they had to get a grip of the local language. In addition, they were trained in modern, American and German standards of medicine and nursing. These young women worked in transnational spaces that introduced them to a multi-cultural humanitarian work place, and to the pragmatism needed for mission work in a Middle Eastern context. Biørn, for example, worked with American, German, and Scandinavian staff, and, in addition, she also worked closely with two Armenian doctors and two Armenian women who helped with caring for the sick children. ${ }^{25}$ These

21 Bjørnlund, "Harput-Missionaries."

22 National Archives (Rigsarkivet), Copenhagen, KMA.36o, pk. nr. 16. Letter from Christa Hammer. February 10, 1902.

23 The American Board had been working in Turkey since 1831. By 19oo, it was the largest, oldest, and most important mission organization involved in the Ottoman Empire. See for example S.E. Moranian, "The Armenian Genocide and American Missionary Relief Efforts," in America and the Armenian Genocide of 1915, ed. J.M. Winter (West Nyack, NY: Cambridge University Press, 2004), 186-213.

24 Bodil Biørn, Diary, December 1905 (Private archives). I would like to thank Jussi F. Biørn for allowing me access to this material.

25 Kvinnelige misjonsarbeidere, Se til hvorledes i bygger videre, K.M.A. gjennom 50 år (Oslo, 1952), 27. 
Armenians were probably trained in the American mission hospital in Mezreh, and they may have grown up in one of the Protestant orphanages in Anatolia. ${ }^{26}$ In the early 19oos, the American Board alone had around sixty orphanages established at various mission stations in Anatolia, which cared for 10,000 orphans. ${ }^{27}$

The mission's humanitarian aspect was the catalyst for Biørn and her colleagues, which led them to choose a life in Ottoman Anatolia. The desire to teach the Protestant faith to the local population was, however, equally important to the Scandinavian women and their German colleagues. This did not mean that they wanted the Armenians to leave the Gregorian (Orthodox) Armenian religion: what they hoped for was a religious reformation of the Gregorian Church. It was a commonly held belief that the Armenians were living in spiritual decay, since they were occupied by Muslims, whose influence had led to heathendom. Scandinavian and German missionaries wanted to create "believing Armenians" who would be able to read the Bible in their own language. ${ }^{28}$ This would facilitate the Protestant ideal of a personal, direct relationship with God. For the missionaries, this meant an emphasis on learning the local language as soon as possible. Missionaries were at a great disadvantage as long as they did not speak Armenian fluently. When Biørn got a grasp of the Armenian language - a tormenting process according to herself-she participated in health visits to urban slum areas, together with Swedish and German nurses and preachers. These visits were often combined with evangelical meetings for women. The female missionaries also went on horseback out to Armenian villages in order to preach to, as well as to attend to the medical needs of local women.

The following example from the Hülfsbund's work in Musch sheds light on how Lutheran missionaries attempted to create "new spiritual life" among the Armenians, by combining humanitarian work and evangelization.

\footnotetext{
26 Bjørnlund, "Harput-Missionaries."

27 Nazan Maksudyan, Orphans and Destitute Children in the Late Ottoman Empire (New York: Syracuse University Press, 2014), 120.

28 Christa Hammer, for example, prayed for a religious reformation and blamed Muslim occupation for what she saw as spiritual decay among the Armenians. National Archives (Rigsarkivet), Copenhagen, KMA.36o, pk. nr. 16. Letter from Christa Hammer. February 10., 1902.
} 
One Sunday morning, Biørn rode out to a village to visit the sick and to "gather the women" for a meeting. After seeing to a patient, she inquired, through the patient's relatives, if the Gregorian minister would allow her to gather Armenian women in the church or in the local school. The Orthodox minister reacted vehemently and accused her of being a "thief, bandit and a Satan", who tried to seduce the people. Biørn did not manage to calm the priest, and she concluded that: "It was one of these fanatic priests, who thinks that we have come to make Germans out of the Armenian people, and make them leave their church, something we in no way want to do". ${ }^{29}$

The animosity towards the "Germans" was not only motivated by the fear of losing Armenians to the Protestant faith. As part of a modernization process, the Turkish state had invited a large number of German engineers and military officers to reform the military and build railways in the Empire. The positive relations between Germans and Ottoman rulers resulted in anti-German sentiments among the Armenian population. ${ }^{30}$

Even so, the main reason for the hostility that the missionaries met from Armenian priests, church leaders, and nationalists, was rooted in a fear that missionaries would have a destabilizing effect on traditional Armenian society. At times the opposition against Western missions, including Scandinavian women, was formidable. At the same time, the mission schools, health clinics, and hospitals were in great demand. While mission journals kept focusing on the need for a Protestant reformation among the Armenians, mission labour in the field was redefined as a practical social vocation. When Bodil Biørn was ordered to Musch in eastern Anatolia in 1907, by the German mission board, her training as a nurse and her years of professional experience in nursing would inform what was to become the main focus of her work. ${ }^{31}$

\section{Mission and Humanitarianism}

The Deutscher Hülfsbund had established a number of mission stations in various areas in the Ottoman Empire, including a small station in Musch where Biørn was stationed from 1907 to 1915. When she arrived in Musch, Biørn was

29 National Archives (Riksarkivet), Oslo, Kvinnelige misjonsarbeidere (KMA) PA 699, nr. oO28. K.M.A. Kvartalshilsen nr. 3 (1910), 24.

30 Communication with Matthias Biørnlund.

$31 \quad$ Inger Marie Okkenhaug, "Women on a Mission! Scandinavian Welfare and the Armenians in the Ottoman Empire, 1905-1917," in Interpreting Welfare and Relief in the Middle East, eds. Nefissa Naguib and Inger Marie Okkenhaug (Leiden: Brill, 2008), 64. 
a seasoned nurse who had worked in various places and under different conditions for more than ten years. Her extensive experience was crucial to the success of her new endeavour, since she now often had to work on her own under demanding, challenging, and, at times, depressing conditions. ${ }^{32}$

Biørn established a polyclinic (outpatients' department, locally named the Doctor's Ward) where 4,00o patients were treated every year. ${ }^{33}$ She also visited yearly around 300 patients in the city and 200 in the villages, together with Alma Johansson (in Musch from 1910). The patients were Armenians, Turks, and Kurds, and they all expected this "doctor" to cure all ailments, the most common being trachoma, malaria, lung diseases, and rheumatism. To assist her, Biørn apprenticed a young Armenian man, who received further education later at the mission hospital. She also had two young Armenian women helping her.

This is an example of the transnational health training that became an important "side benefit" - maybe one of the most important side benefits—of the missionary project in general. In Kharpert, Maria Jacobsen was head nurse in the American Board hospital, where she worked with Armenian nurses, most of whom were orphans who had grown up in one of the American institutions. Here they had received schooling and were trained as nurses. ${ }^{34}$ Or, alternatively, the young women working with Biørn may have gone on to receive a professional training at the German Deaconess School, which was supported by the Hülfsbund.

The German Deaconess School opened in 1904, and it was located at the Hülfsbund's large hospital in Marash. ${ }^{35}$ Here Armenian girls from various German orphanages trained as nurses. Occasionally, Arab and Armenian women, who had been educated in various schools run by German Deaconesses, became members of the Deaconess sisterhood. ${ }^{36}$ Biørn had not been initiated as a Deaconess, but her professional training was based on the same Kaiserwerth model as her younger Armenian colleagues. Even so, European training was not enough. In order for a foreign health worker to practice in the Ottoman Empire, central authorities in Constantinople had to approve the foreign medical training. ${ }^{37}$

32 Kvinnelige misjonsarbeidere, Se til hvorledes i bygger videre, K.M.A. gjennom 50 år, 29.

33 Kvinnelige misjonsarbeidere, Se til hvorledes i bygger videre, K.M.A. gjennom 50 år, 29 .

34 Bjørnlund, "Harput-Missionaries."

35 Uwe Kaminsky, "German 'Home Mission' Abroad:The Orientarbeit of the Deaconess Institution Kaiserswerth in the Ottoman Empire," in New Faith in Ancient Lands: Western Missions in the Middle East in the Nineteenth and Early Twentieth Centuries, ed. H. Murre-van den Berg, scm 32 (Leiden: Brill, 2006), 191-210.

36 Kaminsky, “German 'Home Mission' Abroad," 207-208.

37 Biørn, Diary, December $19 \circ 7$. 
The Scandinavian nurses became part of the many-faceted Ottoman health system, which was constituted by a conglomerate of local, state, and foreign actors and institutions. Alma Johansson, who was trained as a nurse in Sweden, had to pass a nursing exam (conducted in French) that was supervised by health authorities in Constantinople, while the Turkish consulate in Berlin approved Biørn's certificate as a nurse and midwife. Biørn was certified to work with female patients, but not "to give medicine to other ill people", i.e. male patients. In addition, she was forbidden to use sharp instruments, because only certified doctors were authorized to perform operations. Even so, the restrictions of central health authorities had to be ignored when faced with everyday humanitarian challenges. Biørn and Johansson felt they had a moral and professional obligation to meet their patients' needs as best they could. This meant that when necessary they tended to male patients and they performed operations. Working in remote, rural Turkey, led the Scandinavian women to deal with many aspects of health work that they were not allowed to perform at home. The local population expected these two women to perform as "doctors", and as head of the polyclinic, Biørn was known locally as "the doctor". When Alma Johansson took over the clinic, she was named the "new doctor". Both women felt that this title was a burden, yet, to rid themselves of it was impossible. Compared to the Turkish (male) doctors that worked in the area, however, the Scandinavian women felt they were much better qualified to treat sick people. A modern, professional health training and almost total independence in their daily medical practice gave these two female nurses a deep-seated sense of professionalism and capability as health practitioners. ${ }^{38}$ When an Armenian, Roman Catholic doctor tried to forbid Biørn's work, she wrote that she had the confidence of the local people, something this young, inexperienced man did not have. For him the Norwegian woman was a competitor. Despite the problems Biørn encountered as a female, Western health worker operating within a patriarchal context, she continued to see patients in the polyclinic and with home visits. ${ }^{39}$

In rural Ottoman society there were few midwives and the high percentage of women dying in childbirth made Biørn certify as a midwife in Berlin during her first vacation. ${ }^{40}$ Alma Johansson was a trained midwife and in 1911, there were three certified midwives working in the Musch region: one was employed by the government and the other two were Scandinavians. In addition to the

38 The Swedish National Archives (Det svenske riksarkivet), Arninge, KMA-arkivet, SE/RA/73 0147/F/F3/F3a/2. Letter from Alma Johansson, Musch (November 2, 1910).

39 National Archives (Riksarkivet), Oslo. KMA Kvartalshilsen, nr. 3 (1912), 27.

40 Kvinnelige misjonsarbeidere, Se til hvorledes i bygger videre, K.M.A. gjennom 50 år, 30 . 
large number of patients, the working conditions in these mountain villages were extremely difficult. There were no roads and the midwives had to walk or ride long distances. The general level of health was low. In addition, there was resistance among the local population to seek the help of the midwife. Women's second rate position in Ottoman society meant that some men did not want to pay for professional help when their wives were about to give birth.

Biørn and Johansson did not cooperate with the local certified midwife, but saw her as a competitor. They suspected that she was not qualified and the local midwife and Johansson had several clashes. ${ }^{41}$ In addition to this midwife, there were unskilled, local women who were paid helpers during births. These women were also against seeking the help of the Scandinavians, since it would mean the end of their livelihood. As a result, Biørn and Johansson were called as a last resort and only when the traditional helpers had to give up. The great distances — often a five-six hour hike - meant that when they finally arrived, it was often too late to save the lives of the mother and child. Over the years, however, there were several improvements: for example, women who were about to give birth learned to send for the midwife in time. ${ }^{42}$

In addition to improved health conditions, Protestant missions saw education as a way of transforming women's lives both spiritually and materially. As shown by historian Barbara J. Merguerian, in Kharpet (Harput) in eastern Turkey, the American Board established elementary schools for girls (from 1855 onwards), teaching Armenian women to read, as an early version of "women's work for women". ${ }^{43}$ Girls and young women, as future mothers of children, educated in Protestant values, would be "instruments of socialization and the potential founders of homes established on Christian (Protestant) virtues and principles". ${ }^{4}$ The belief in giving attention, time, and resources to the education for women was shared by Scandinavian and German Protestant missionaries in the Ottoman Empire.

The Deutscher Hülfsbund established a number of schools for both Armenian boys and girls. This was part of their work among Armenian orphans

41 The Swedish National Archives, Letter from Alma Johansson (January 24, 1914).

42 The Swedish National Archives, Letter from Alma Johansson.

43 B.J. Merguerian, "'Missions in Eden': Shaping an Educational and Social Program for the Armenians in Eastern Turkey (1855-1895)," in New Faith in Ancient Lands: Western Missions in the Middle East in the Nineteenth and Early Twentieth Centuries, ed. Heleen Murre-van den Berg, scm 32 (Leiden: Brill, 2006), 252.

44 E. Fleischmann, "Evangelization or Education: American Protestant Missionaries, The American Board, and the Girls and Women of Syria (1830-1910)," in New Faith in Ancient Lands: Western Missions in the Middle East in the Nineteenth and Early Twentieth Centuries, ed. Heleen Murre-van den Berg, SCM 32 (Leiden: Brill, 2006), 268. 
and included primary education. In the first three grades, the children were taught the Armenian language, as well as Turkish in Armenian script and Ottoman Turkish. As mentioned previously, German and Scandinavian Protestants believed it was crucial to learn to read and write in order to understand the Bible in one's own mother tongue. ${ }^{45}$ In the Deutscher Hülfsbund's ideology, however, education was not only necessary for Armenian girls and boys in order to reach a spiritual religious reformation, it was also a means to modernize Middle Eastern society. This "enlightenment program" included both sexes, and one central concern was the attempt to eliminate the high level of illiteracy among young girls in the general populace, whom were not in the care of mission orphanages. ${ }^{46}$

In 1908, the Deutscher Hülfsbund established a day school for girls in Musch, initiated by Bodil Biørn, and financed by German and Norwegian supporters. The school was run by two Armenian female teachers. After initial skepticism among the local population, girls - some of them young wives and motherscame to school, and after some time there were 120 pupils in attendance. The school may have been the first one for girls in Musch. The two teachers, Maritza and Margarit, had grown up in Emaus, in the Scandinavian orphanage in Mezreh, and they were trained in a teacher's seminary run by the American Board.

In Musch, Maritza and Margarit taught young girls to read and write, and the girls also recieved instruction in mathematics, the Bible, and sewing. The curriculum was a means of transfer of religious beliefs, but just as important was the emphasis on teaching the girls a practical skill, which would be a means to "help-to-self-help" for young women who later might have to support parents and siblings.

To run a school was expensive. Some of the pupils were poor and in ill-health and they needed clothes and medicine, in addition to books. Biørn argued, however, that the school was an excellent way of reaching the children, and that the school would open the way to parents and to the wider society. ${ }^{47}$ In practical terms, the school had the unintended effect (from the missionaries' point of view) of bringing about the establishment of more schools for

45 Later on, the pupils also learned English, history, and geography. After the Young Turk revolution in 19o8, physical education and German were introduced. Hayk Martirosyan, "German Missionary Activity in the Ottoman Empire: Marash Station (1896-1919)," The International Raoul Wallenberg Foundation, http://www.raoulwallenberg.net/filmsboo ks/book-german-missionary-activity-in-the-ottoman-empire-marash-station-1896-1919/.

46 Lohmann, Skildringer af Armeniske Forhold og Tilstande, 3 о.

47 National Archives (Riksarkivet), Oslo. KMA Kvartalshilsen nr. 3 (1914), 28. 
the local population. The Ottoman government established schools partly as a reaction towards the many foreign mission schools, many of which were especially aimed at Christian minorities. "In response to this interference with its subjects", historian Elizabeth Thompson writes, "the Ottoman state built its national schools as a bulwark against foreign subversion, as a direct bond between state and citizen". 48

The government schools aimed to promote loyalty to the Ottoman state. Even so, yet another group had ambitions regarding education of the Armenian children and youth. Armenian politicians saw both mission schools and the Ottoman government's educational institutions as counterproductive to their nationalist aims. The main threat was the numerous mission schools, which catered for Armenian children at all ages. Political activists feared that exposure to foreign missionary education would mean that children lost their culture, religion, and Armenian identity. To counter this development, Armenian nationalists often established their own schools in areas where there existed missionary schools. This happened in Musch, where the prominent national leader Simon Zavarian initiated and ran an Armenian school around 1910.49 Missionary schools thus generated competition, which meant increased possibilities for education for the local population. The fused history of these three competing benefactors, the Ottoman state, the Armenian nationalists, and the foreign missionaries, of education for the Armenian population, exemplify how "the missionary encounter" could be a product of complex interactions between local, foreign, and state actors. Among the local population, Armenian girls and women may have gained the most from this encounter, since Protestant missions gave equal weight to male and female literacy, while local schools were less inclined to offer girls education.

\section{Conclusion}

A young Norwegian woman's religious calling to relieve and prevent suffering from sickness and poverty, led to a working career in the Middle East. Ideologically and practically, this mission work was carried out in transnational spaces. Bodil Biørn's mission was deeply inspired by the Scandinavian KMA's “women's work for women", and it included relief work, education, and spiritual reformation. One way of improving the lives of Armenian girls was the establishment

48 Elizabeth Thompson, Colonial Citizens: Republican Rights, Paternal Privilege, and Gender in French Syria and Lebanon (New York: Columbia University Press, 200o), 75.

Panossian, The Armenians, 176. 
of a school for girls. Some of the girls trained as teachers and nurses in Protestant institutions, thus joining the small, but growing numbers of professional women in the Ottoman Empire in the early 19oos.

Local hostility and opposition did not mean that Biørn and fellow missionaries gave up evangelization, but their efforts were by far dominated by practical humanitarian work: nursing, medical attendance, and education. The lack of medical help among women also led Biørn to specialize as a midwife. In fact, midwifery may have been one of the most important legacies of Scandinavian missionaries in eastern Anatolia before World War I and the Armenian genocide. 


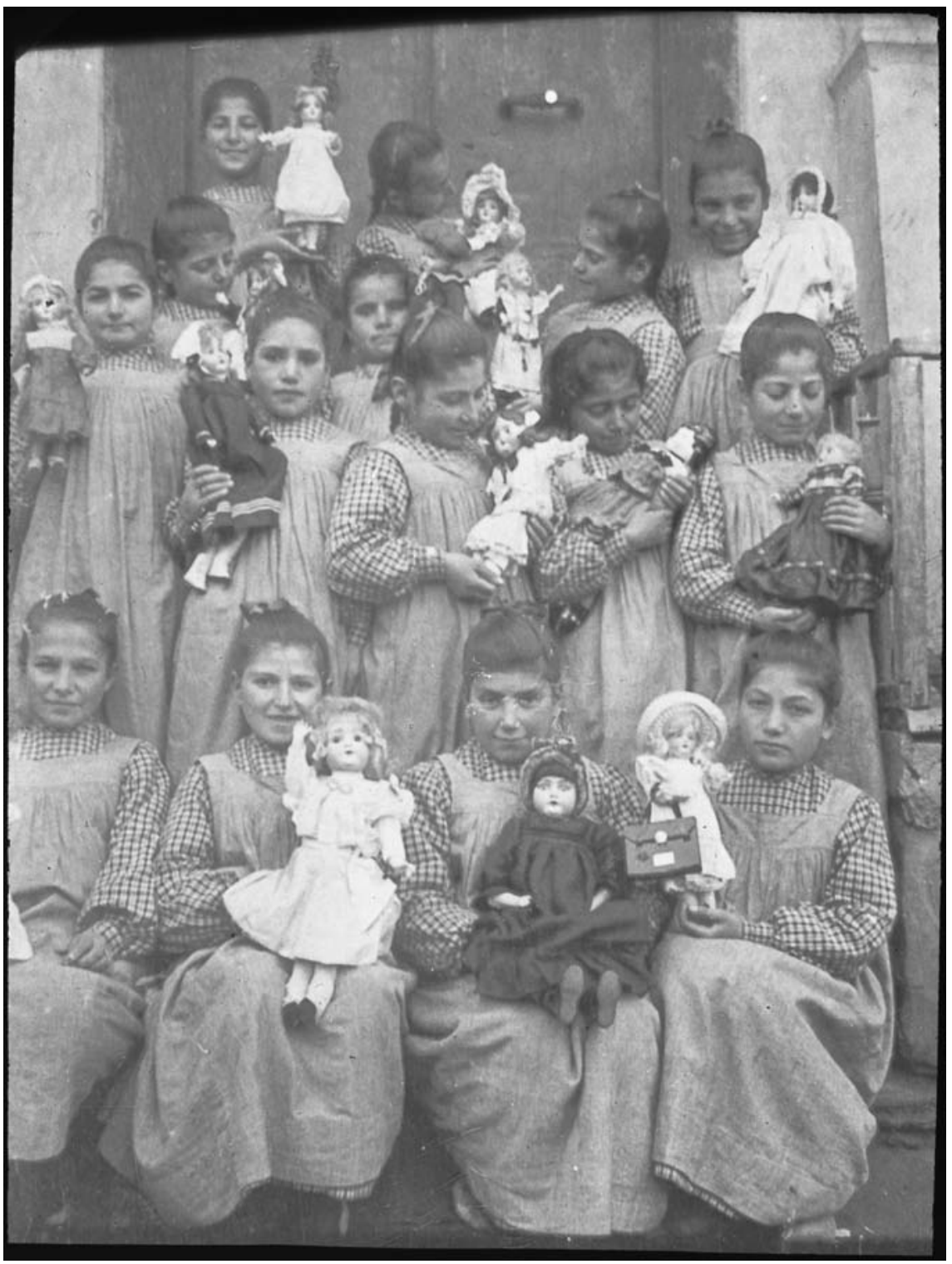

FIGURE 4.1 Girls in the orphanage in Musch with dolls from Scandinavian donors. Note: "Barn ved Musch barnehjem?" Wikimedia, made available by National Archives of Norway, https://commons.wikimedia.org/wiki/File:Barn_ved_Musch _barnehjem\%3F_-_fo3014171218005o.jpg 


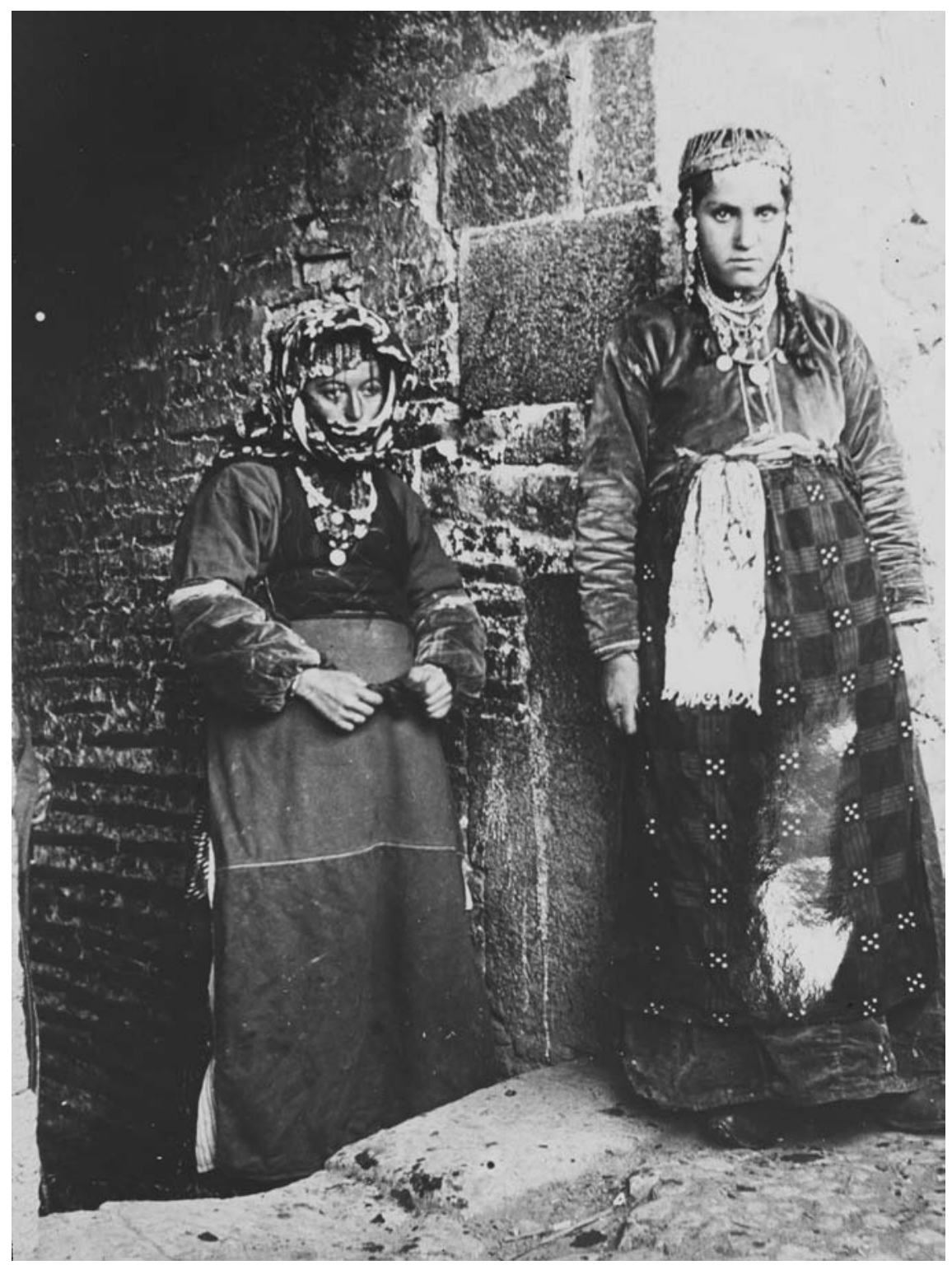

FIGURE 4.2 Armenian women.

Note: "Armenske kvinner," Wikimedia, made available by National Archives of Norway, https://commons.wikimedia.org/wiki/File:Armenske_kvinner__fo30141712190013_1469.jpg 


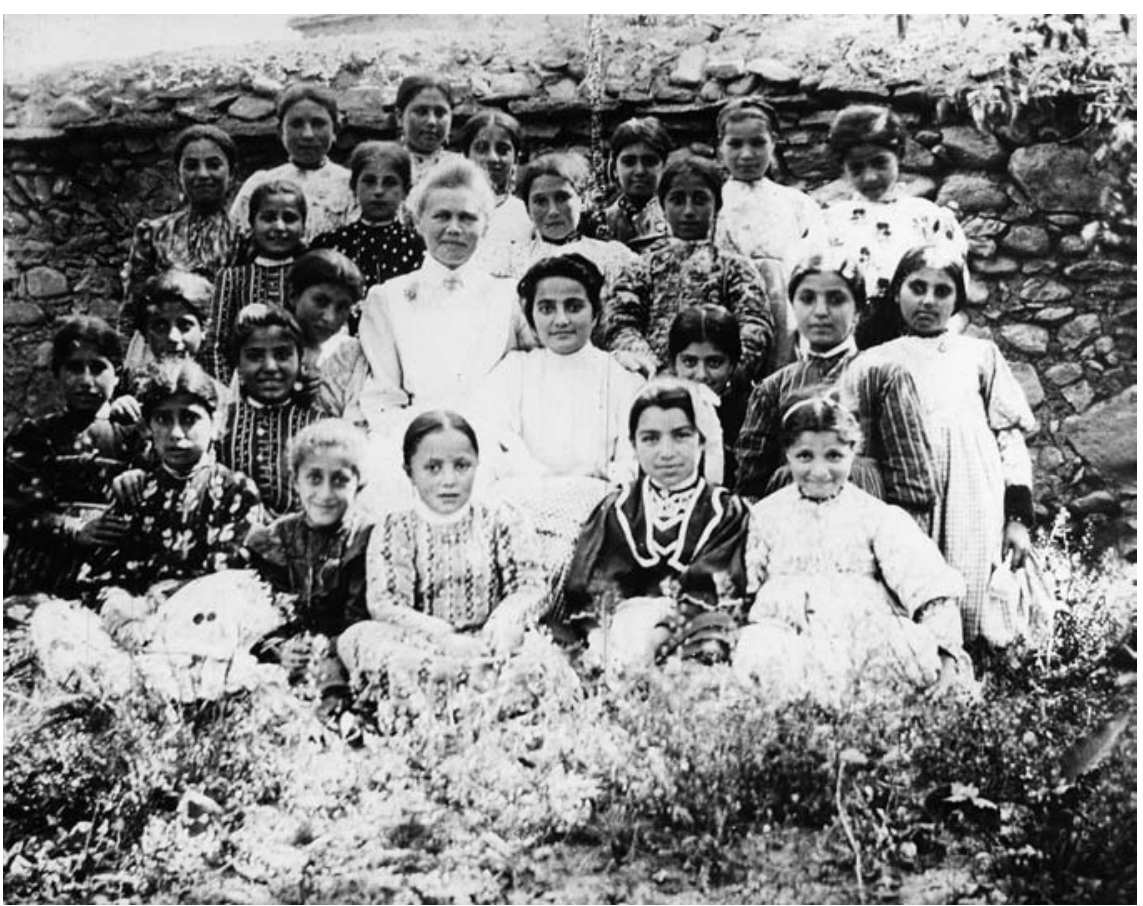

FIGURE 4.3 Bodil Biørn and teacher Maritza with 1st grade in Mush, ca. 1912.

Note: "Bodil Biørn med skoleklasse," Wikimedia, made available by National Archives of Norway, https://commons.wikimedia.org/wiki/File:Bodil_Bi\%C3 \%B8rn_med_skoleklasse_-_fo30141712180005.jpg

\section{Bibliography}

\section{Primary Sources}

Biørn, Bodil. Diary (Private archives). I would like to thank Jussi F. Biørn for allowing me access to this material.

National Archives (Riksarkivet), Oslo. KMA, PA 699.

National Archives (Rigsarkivet), Copenhagen. KMA 10.36o.

National Archives (Det svenske riksarkivet), Arninge KMA-arkivet. SE/RA/73O147.

Kvinnelige misjonsarbeidere. Se til hvorledes i byggervidere, K.M.A. gjennom 50 år. Oslo $195^{2}$.

Wikimedia, made available by National Archives of Norway. "Armenske kvinner." https://commons.wikimedia.org/wiki/File:Armenske_kvinner_-_fo30141712190013_ 1469.jpg.

Wikimedia, made available by National Archives of Norway. "Barn ved Musch barnehjem?” https://commons.wikimedia.org/wiki/File:Barn_ved_Musch_barnehjem\%3 F_-_fo3014171218005o.jpg. 
Wikimedia, made available by National Archives of Norway. "Bodil Biørn med skoleklas se.” https://commons.wikimedia.org/wiki/File:Bodil_Bi\%C3\%B8rn_med_skoleklas se_-_fo30141712180005.jpg.

\section{Secundary Sources}

Bjørnlund, Matthias. "A Fate Worse than Dying: Sexual Violence during the Armenian Genocide." In Brutality and Desire: War and Sexuality in Europe's Twentieth Century, edited by Dagmar Herzog. Basingstoke: Palgrave, 2009.

Bjørnlund, Matthias. "Harput-Missionaries, Danish Missionaries in the Kharpert Province: A Brief Introduction." Houshamadyan. Accessed May 23, 2018. http://www .houshamadyan.org/mapottomanempire/vilayetofmamuratulazizharput/harputka za/religion/missionaries.html.

Fleischmann, Ellen. "Evangelization or Education: American Protestant Missionaries, The American Board, and the Girls and Women of Syria (1830-1910)." In New Faith in Ancient Lands: Western Missions in the Middle East in the Nineteenth and Early Twentieth Centuries, edited by Heleen Murre-van den Berg. sсм 32. Leiden: Brill, 2006.

Hauser, Julia. "From Transformation to Negation: A Female Mission in a 'City of Schools." Journal of World History 27, no. 3 (September 2016): 473-496.

Kaminsky, Uwe. "German 'Home Mission' Abroad: The Orientarbeit of the Deaconess Institution Kaiserswerth in the Ottoman Empire." In New Faith in Ancient Lands: Western Missions in the Middle East in the Nineteenth and Early Twentieth Centuries, edited by H. Murre-van den Berg. Leiden: Brill, 2006.

Keshgegian, Flora A. “'Starving Armenians': The Politics and Ideology of Humanitarian Aid in the First Decades of the Twentieth Century." In Humanitarianism and Suffering. The Mobilization of Empathy, edited by Richard Ashby Wilson and Richard D. Brown. Cambridge: Cambridge University Press, 2008.

Lohmann, Ernst. Skildringer af Armeniske Forhold og Tilstande. Copenhagen, 1902.

Lønnå, Elisabeth. “Gender in Norway in the Period of Mass Emigration." In Norwegian American Women. Migration, Communities and Identities, edited by Betty A. Bergland and Lori Ann Lahlum. St Paul: Minnesota Historical Press, 2011.

Maksudyan, Nazan. Orphans and Destitute Children in the Late Ottoman Empire. New York: Syracuse University Press, 2014.

Martinsen, Kari. Freidige og uforsakte diakonisser: et omsorgsyrke vokser fram, 1860-1905. Oslo: Aschehoug/Tanum-Norli, 1984.

Martirosyan, Hayk. "German Missionary Activity in the Ottoman Empire: Marash Station (1896-1919)." The International Raoul Wallenberg Foundation. http://www.raou lwallenberg.net/filmsbooks/book-german-missionary-activity-in-the-ottoman-em pire-marash-station-1896-1919/.

Merguerian, B.J. “'Missions in Eden': Shaping an Educational and Social Program for 
the Armenians in Eastern Turkey (1855-1895)." In New Faith in Ancient Lands: Western Missions in the Middle East in the Nineteenth and Early Twentieth Centuries, edited by Heleen Murre-van den Berg. scm 32. Leiden: Brill, 2006.

Moranian, S.E. "The Armenian Genocide and American Missionary Relief Efforts." In America and the Armenian Genocide of 1915, edited by J.M. Winter. West Nyack, NY: Cambridge University Press, 2004.

Norseth, Kristin. "La os bryte over tvert med vor stumhet: kvinners vei til myndighet $\mathrm{i}$ de kristelige organisasjonene 1842-1912." PhD diss., University of Oslo, 2007.

Nyhagen Predelli, Line. "Emma Dahl: Contesting the Patriarchal Gender Regime of the Norwegian Missionary Society in Madagascar." Scandinavian Journal of History 2 (2003).

Okkenhaug, Inger Marie. "Women on a Mission! Scandinavian Welfare and the Armenians in the Ottoman Empire, 1905-1917." In Interpreting Welfare and Relief in the Middle East, edited by Nefissa Naguib and Inger Marie Okkenhaug. Leiden: Brill, 2008.

Okkenhaug, Inger Marie. "En norsk filantrop": Bodil Biørn og armenerne, 1905-1934. Kristiansand: Portal forlag, 2016.

Okkenhaug, Inger Marie. "Herren har givet mig et rigt virkefelt. Kall, religion og arbeid blant armenere i Det osmanske riket" ("Vocation, Religion and Work Among Armenians in the Ottoman Empire"). Historisk Tidsskrift (Journal of History) 1 (2009): 39-6o.

Okkenhaug, Inger Marie. "Norwegian Nurses, Relief and Welfare in the United States and Middle East, ca. 1880-1915." In Transnational and Historical Perspectives on Global Health, Welfare and Humanitarianism, edited by Ellen Fleischmann, Sonya Grypma, Michael Marten, and Inger Marie Okkenhaug. Kristiansand: Portal forlag, 2013.

Panossian, Razmik. The Armenians: From Kings and Priests to Merchants and Commissars. New York: Columbia University Press, 2006.

Paulmann, Johannes. "Conjunctures in the History of International Humanitarian Aid during the Twentieth Century." Humanity 4, no. 2 (Summer 2013). http://humanityjo urnal.org/wp-content/uploads/2014/o6/4.2-Conjunctures-in-the-History-of-Intern ational-Humanitarian-Aid-during-the-Twentieth-Century.pdf.

Richter, Julius. History of Protestant Missions in the Near East. London: Fleming H. Revell Company, 1910.

Store Norske Leksikon. "Hellighetsbevegelsen." Accessed September 20, 2018. https:// snl.no/hellighetsbevegelsen.

Thelen, David. "The Nation and Beyond: Transnational Perspectives on United States History." The Journal of American History 86, no. 3 (1999): 965-975.

Thompson, Elizabeth. Colonial Citizens: Republican Rights, Paternal Privilege, and Gender in French Syria and Lebanon. New York: Columbia University Press, 200. 


\title{
"A Strange Survival": The Rev. W.A. Wigram on the Assyrians before and after World War I
}

\author{
Heleen Murre-van den Berg
}

\section{1 \\ Introduction}

One of the most prolific writers on the Assyrians of the Church of the East was the Anglican missionary William Ainger Wigram (1872-1953), who worked for the Archbishop of Canterbury's Mission to the Assyrian Christians from 1901 to 1912. His range of well-illustrated books on the history of the Church of the East and the life of the contemporary Assyrians are considered to have played an important role to bring the plight of the Assyrians to the attention of the general public, especially in Great Britain. Wigram became most famous for his post-war pamphlet entitled Our Smallest Ally, in which he lauded the military contribution of the Assyrians to the British and Allied war-efforts in the Kurdish region. Together with the Russians and Armenians, they took up arms against the Ottoman armies after it became clear that the Ottomans were on their way to expulse all Christians from Eastern Turkey. However, the fight for Kurdistan was lost and many of the Assyrians from the Hakkari Mountains ended up in a British refugee camp in Baquba, near Baghdad. In Our Smallest Ally Wigram pressed home British responsibility for the future of this vulnerable people that had been caught up by events beyond their control. The pamphlet's frank criticism of British politics in Iraq made it an important source for contemporary and later anti-colonial Assyrian historiography, even if the pamphlet, like Wigram's other works, was firmly rooted in British imperial and colonial perceptions of the world.

This may come across as a pretty straightforward way of a missionary acting as an advocate for a people with whom he became involved over the years. A closer look, however, at Wigram's publications suggests that his advocacy in many respects was different from most of his missionary colleagues of the time. Most obviously, Wigram's activities were further removed from the struggles of day-to-day relief work that brought so many of the American missionaries to their pleas for humanitarian action. Their experiences led them to become actively engaged in humanitarian aid, in connection with but also independent 
of missionary organizations and missionary aims. ${ }^{1}$ It is this turn to humanitarian action in the context of war, massacre and displacement that is the main topic of the current volume. What I intend to bring to the fore in the current contribution is that this turn to active and secularized humanitarianism was not the only option open to missionaries. Anglican missionaries in general and Wigram in particular chose a different route, a route that on the one hand was intricately connected with British colonial interests in the region, and on the other with ecumenical and scholarly concerns. Nevertheless, I will argue that despite their different emphases, Wigram's publications are as much part of the turn away from conversionist and civilizational missions as the activities and accompanying publications of his mostly American colleagues.

\section{The Anglican Missions in Hakkari, Persia, Mesopotamia}

By the time William Wigram became a part of the Anglican mission, the Archbishop of Canterbury's Mission to the Assyrian Christians already had a long history. The mission's (and Wigram's) biographer, J.F. Coakley, traces its beginnings to early contacts between Anglican clerics such as George Percy Badger in the 1840 s and the Church of the East in the Eastern provinces of the Ottoman Empire and northwestern Iran. The Archbishop of Canterbury's mission was established in Urmia (Persia) in 1886. Like the earlier established Protestant (ABCFM and later Presbyterian) and Catholic (Lazarist and Catholic) missions, the Anglicans operated their own press that published mostly educational and liturgical books. After also Russian and German, Scandinavian and American Lutheran missionaries arrived at the scene, the Assyrian community of the Urmia region could choose from a surprisingly high number of

1 Keith David Watenpaugh, Bread from Stones: The Middle East and the Making of Modern Humanitarianism (Berkeley: University of California Press, 2015) underlines the importance of American missionary organizations and individuals in understanding the initiatives as well as the ambiguities of modern day humanitarian actions, including ongoing racialized thinking; see also Miriam Ticktin's review of Watenpaugh, "Humanity as Concept and Method: Reconciling Critical Scholarship and Empathetic Methods," Comparative Studies of South Asia, Africa and the Middle East 37, no. 3 (2017): 608-613. No in-depth study has been written about the American missionary relief activities for the Assyrians during the war, but most studies of this mission (see n. 2 and 4) pay attention to their work. One of the most impressive memoirs of missionary humanitarianism among the Assyrians is that by Mary Lewis Shedd on her husband: The Measure of a Man: The Life of William Ambrose Shedd, Missionary to Persia (New York: George H. Doran, 1922). 
missionary activities, albeit that the Assyrians of the hard-to-travel Hakkari Mountains generally remained far removed from the more intense engagement with the missions that took place in the Urmia plain. In Mosul and its environs, the mostly Catholic (French Dominican) missionaries dominated ecclesial and educational work among Assyrian as well as Chaldean, Syriac Orthodox, and Syrian Catholic communities. ${ }^{2}$

Over the years, the Anglicans fostered a reasonably good relationship with the leadership of the Church of the East, especially because they, different from the Presbyterian, Lazarist, and Dominican missions, had no intention to convert individual Assyrians to the Anglican church or to forge a union between the Church of the East and Anglican church. They considered the Church of the East a sister church that certainly was in need of education and reform, but was also to be respected as an independent local church. It was upon their request for support, especially concerning the education of the clergy and the printing of liturgical books that the Anglicans offered their service-a kind of mission that dovetailed with the ecumenical and liturgical concerns of the Archbishop of Canterbury. ${ }^{3}$

Because of these converging aims, the Anglican mission was able to maintain good relationships with the ecclesial head of the Church of the East and his family, first patriarch Mar Shimun XVIII Ruel (186o-1903), then Mar Shimun XIX Benyamin (1903-1918). For most of the period under discussion, the hereditary patriarch resided in Qodshanis, in the Ottoman part of the Hakkari Mountains, where he also acted as the tribal leader of the Assyrian mountain clans, negotiating their internal disputes as well as representing the Assyrian case with the Kurdish leaders of the region. From the winter of 1887/88 till his death in 1910, William Henry Browne, one of the pioneer Anglican missionaries, resided in Qodshanis rather than in the Persian city of Urmia where most of his colleagues lived. In addition to maintaining a small medical dis-

2 On the Anglican mission in Urmia, see J.F. Coakley, The Church of the East and Church of England: A History of the Archbishop of Canterbury's Assyrian Mission (Oxford: Clarendon Press, 1992); on the other missions, see John Joseph, The Modern Assyrians of the Middle East: Encounters with Western Christian Missions, Archeologists, and Colonial Powers, SCM 26 (Leiden: Brill, 20oo, revised); Heleen Murre-van den Berg, From a Spoken to a Written Language: The Introduction and Development of Literary Urmia Aramaic in the Nineteenth Century, Publication of the "De Goeje Fund" 28 (Leiden: NINO, 1999); Adam Becker, Revival and Awakening: Christian Mission, Orientalism, and the American Evangelical Roots of Assyrian Nationalism (1834-1906) (Chicago: Chicago University Press, 2015); Thomas S.R. O'Flynn, The Western Christian Presence in the Russias and Qājär Persia, c.1760-c.187o, SCM 47 (Leiden: Brill, 2017).

3 Coakley, The Church of the East, chapters vi and viI. 
pensary, Browne taught the children of the extended patriarchal family, including patriarch-to-be Benyamin and his sister Surma.

In 1897, Russian Orthodox missionaries intensified earlier attempts to bring the Assyrians into the Eastern Orthodox fold. With the Russian civil and military presence in the region, this was a more attractive partner to the traditionalist Assyrians than the Anglicans. Though the latter expressed some misgivings over this quick change of sympathies, on theological and historic grounds they felt compelled to leave the field to their ecumenical Russian partners and moved their school to Van, on the Ottoman side of the Hakkari mountain range, where they continued to take in Assyrian students. In 1910, the school was moved to the village of Bebaydi in today's North Iraq, where it had to be closed a few years later when the Anglicans left at the outbreak of the war. After the war, the mission house in Bebaydi briefly served as the home of the displaced patriarchal family. During the war years and after, the Anglican mission committee in the England collected funds to support the Assyrians in the hardship that followed upon expulsion and displacement, first from the Hakkari Mountains to Urmia, then from Urmia to Hamadan and the refugee camps in Baquba and Mindan. The money that was collected in England found its way not only to the Assyrians in British-supervised camps, but also to those who started to reestablish their lives in North Iraq and later in Syria. During the war, books and pamphlets, such as The Death of a Nation, or the Ever Persecuted Nestorians or Assyrian Christians by Abraham Yohannan (New York, 1916), brought the plight of the Assyrians under the attention of the British public. ${ }^{4}$

After the war, the mission did not re-establish itself among the Assyrians of Iraq or Persia, but remained involved in the situation of the Assyrians. The post-war Archbishops of Canterbury, Randall Davidson (1903-1928) and Cosmo Gordon Lang (1928-1942), were in regular contact with the British High Com-

4 Coakley, The Church of the East, 338, 353. On the Assyrians during the war, see (in addition to the sources mentioned in n. 2), Florence Hellot-Bellier, Chroniques de massacres annoncés: Les Assyro-Chaldéens d'Iran en du Hakkari face aux ambition des empire, 1896-1920 (Paris: Geuthner, 2014); David Gaunt, Massacres, Resistance, Protectors: Muslim-Christian Relations in Eastern Anatolia during World War I (Piscataway, NJ: Gorgias Press, 2006); Sargon George Donabed, Reforging a Forgotten History: Iraq and the Assyrians in the Twentieth Century (Edinburgh: Edinburgh University Press, 2015). On the Baquba camp, see H.H. Austin, The Baqubah Refugee Camp: An Account of Work on behalf of the Persecuted Assyrian Christians (London: The Faith Press, 1920); H. Mueller, "The League of Nations, A-Mandates and Minority Rights during the Mandate Period in Iraq (1920-1932)," in Modernity, Minority, and the Public Sphere: Jews and Christians in the Middle East, eds. S.R. Goldstein-Sabbah and H.L. Murre-van den Berg, LSIS 4, (Leiden: Brill, 2016), 258-283; Laura Robson, States of Separation: Transfer, Partition, and the Making of the Modern Middle East (Stanford: University of California Press, 2017). 
missioners of Mesopotamia about the Assyrians and their resettlement. They also kept in contact with Dr. Panfil, an Episcopal missionary from the United States who had been sent to support the Assyrians of Iraq. Anglican educational work in the Jazeera region of French Mandate Syria, where some of the Assyrians had ended up after 1933, did not prosper. After the contacts with and aid to the Assyrian Church of the East were taken over by the Anglican bishopric of Jerusalem (and supported by the Anglican Jerusalem and East Mission), the mission committee in England continued to support the patriarchal family, first in Bebaydi, then on Cyprus and later in England, until the various members of the family moved to the United States in the 1940s. ${ }^{5}$

\section{Wigram and His Writings}

William Ainger Wigram was born in 1872 in a lower-gentry vicar's family in Furneaux Pelham. He enjoyed the benefits of a solid classical education, with years at King's School in Canterbury and at Trinity Hall in Cambridge before he became an Anglican cleric. ${ }^{6}$ After ordination in 1897 he worked at two parishes before he joined the mission in 1902 where he was assigned to oversee the ordinands' school in Van. ${ }^{7}$ At the beginning of his second five-year term he was appointed as the head of the mission and as such was responsible for building a new mission post in Bebaydi in 1910. Wigram left the mission in 1912 to become a chaplain in Constantinople, where he was interned during in the war. Before he could make his way home when the war was finished, he was reposted to Iraq to assist the British colonial officers in the resettlement of displaced Assyrians in Baquba. After resettlement schemes failed in 1922, Wigram left for another stint in Constantinople, although he returned to Iraq for a brief visit in 1928. He continued his ecclesial career first in Greece (1922-1926), then on Malta (1928-1936). His last years he spent in England where he died in Salisbury in 1953. Over the years he remained keenly interested in Assyrian affairs, publishing and advocating for the Assyrians and the patriarchal family, and never quite loosing contact with them.

5 Coakley, The Church of the East, chapter viI.

6 In $19 \circ 9$ he received the Doctor of Divinity (D.D. Lambeth) degree from the Archbishop of Canterbury, acknowledging his scholarly work in service of the church; in 1919 or 1920 he received a regular Cambridge Doctor of Divinity (B.D.) degree, see n. 15 .

7 The following is based on Coakley's The Church of the East and on a concise biography by the same author: J.F. Coackley, "Wigram, William Ainger (1872-1953)," in Oxford Dictionary of National Biography, ed. Lawrence Goldman (Oxford: OUP, 2004). Available via http://www .oxforddnb.com/view/article/58374. 
Wigram started publishing on Assyrian matters during his second term at the mission, with a position paper presented to the Lambeth Conference of 1908. One of the important themes of this international intra-Anglican conference concerned ecumenical relations and intercommunion with Eastern Churches. Wigram contributed a paper on the Church of the East, under the title The Doctrinal Position of the Assyrian Church. While at the time the deliberations did not lead to any concrete steps, Wigram's paper argued that the supposedly heretical position of the so-called "Nestorian" Church could be reinterpreted more congenially as being much closer to what the Anglicans and Eastern Orthodox considered the orthodox view. Although the Anglican missionaries among the Assyrians differed in their exact views on this, overall the mission tended to attribute the differences between Anglican and Church-ofthe-East theology to matters of translation and historical interpretation rather than to deep-seated doctrinal differences. Wigram consistently argued that the Church of the East was an independent and orthodox Christian church and thus advocated full communion. ${ }^{8}$

His views on the history of the Assyrian Church were further expounded in his second book, An Introduction to the History of the Assyrian Church: Or the Church of the Sassanid Persian Empire, 100-640A.D. which was published in 1910. This book can be read as a fuller exposition, for a wider public, of his views on the early history and doctrinal position of the Church of the East. ${ }^{9}$ His choice to again use the epithet "Assyrian" in the title underlines this: in the preface he rejects other current names for this church as misleading to the English reader, by referring to geographical areas not consistent with modern names and regions ("Syrian", "Persian") or because "Nestorian' has a theological significance which is not justified". "Assyrian", on the contrary, "has at least the merit of familiarity to most friends of the Church to-day". ${ }^{10}$ His second full-length book on the Assyrians was published in 1914, entitled The Cradle of Mankind: Life in Eastern Kurdistan. ${ }^{11}$ This travelogue contains a lively description of contemporary life in the Eastern provinces of the Ottoman Empire and the adjacent provinces of Urmia, introducing Assyrian customs against the background of the wider population. Wigram collaborated with his brother

8 Coakley, The Church of the East, 285, 296-297.

9 This sympathetic reading of the Church of the East's Christology is clear from the book as whole, and is explicated and brought to the present in ch. XII, 'Official Christology of the Assyrian Church,' W.A. Wigram, An Introduction to the History of the Assyrian Church: Or the Church of the Sassanid Persian Empire, 100-640 (London: SPCK, 1910), 265-298.

10 Wigram, An Introduction, vii-viii.

11 W.A. Wigram, The Cradle of Mankind: Life in Eastern Kurdistan (London: Adam \& Charles Black, 1914); Second edition (London: Adam \& Charles Black, 1922). 
Edgar T.A. Wigram who was a travel writer in his own right. All sketches and photographs in the volume are attributed to Edgar, but to what extent he also contributed to the text remains unclear.

After William Wigram's post-war travel to Iraq, he authored two small pamphlets which dealt with what must have been the two most pressing issues on his mind. The first, Intercommunion with the Assyrian Church, addressed the ecumenical relations between the Assyrians and the Anglican Church, the second, Our Smallest Ally, addressed the political relations between the Assyrians and Great Britain. Both pamphlets were published in England in 1920, the second also simultaneously in the United States. In the first, he revisits and restates his earlier position on the fundamental orthodoxy of the Church of the East, arguing for full and speedy recognition of the Assyrian church as a sister church. ${ }^{12}$ The second pamphlet is the one that is best known today, posted on Assyrian websites like Atour.com and often referred to in discussions. In it, Wigram argues for ongoing British involvement with the Assyrians, because of the valuable service they rendered to the British during the war as well as their potential in pacifying Iraq: "Can Great Britain, now that she is responsible for order in the country, afford to neglect so valuable a military asset as this nation has proved itself to be?"13

In 1922, The Cradle of Mankind was republished with two extra chapters that largely overlap with Our Smallest Ally, pressing home the same point of British obligation towards the Assyrians. In that same year, the pamphlet The Assyrian Settlement was published. ${ }^{14}$ In 1923, he published his Cambridge dissertation The Separation of the Monophysites on the history of what today is usually called the Miaphysite tradition, especially that of the Syriac Orthodox Church. ${ }^{15}$ In 1929, he published The Assyrians and their Neighbours. All major

12 "Intercommunion with the Assyrian Church by William Ainger Wigrim, D.D.," Project Canterbury, accessed March 30, 2018, http://anglicanhistory.org/orthodoxy/wigram/assyrianı 920.html.

13 W.A. Wigram, Our Smallest Ally: A Brief Account of the Assyrian Nation in the Great War (London: SPCK; New York: Macmillan, 1920), 57. This was written after he worked in the Baquba refugee camp; the pamphlet includes an introduction by H.H. Austin, the British officer in charge of the camp. Similarly, Wigram, The Cradle, 2nd ed., 451. On the military aspect of Assyrian identity, see also Heleen Murre-van den Berg, "Writing Assyrian History: The Military, the Patriarch and the British in Yaqu bar Malek Ismael's Assyrians in Two World Wars (Tehran 1964)," in Sayfo 1915: An Anthology of Essays on the Genocide of Assyrians/Aramaeans during the First World War, eds. Shabo Talay and Soner O. Barthoma, Gorgias Eastern Christian Studies 50 (Piscataway: Gorgias Press, 2018), 213-230.

14 Unfortunately I have been unable to find a copy of this publication.

15 Its introduction relates how he originally submitted a dissertation on the same topic in 1914, also at Cambridge. It was accepted, but Wigram was not able to finalize the proced- 
themes return here, with the history of the Assyrians situated against the background of British Iraq where the brave Assyrians should find new homes after the devastations of war.

That this was not to come to pass, at least not in the way Wigram envisaged it, became clear in 1933, not long after the British had been forced to give up Mandate rule in Iraq. The Semele massacre of recently disarmed Assyrians brought to light the antagonisms that had built up against the refugee Hakkari Assyrians in Iraq, resulting in the expulsion of those that survived to French-ruled Syria or further afield. ${ }^{16}$ In these years Wigram continued to advocate the sake of the Assyrians, but in such a way that he lost his clout with the Archbishop of Canterbury-delicate as these matters were in relation to ongoing British interests in Iraq. While he continued to publish journal articles on the Assyrians, his only further major publication was related to another of his lifelong interests, Hellenic Travel: A Guide (1947). ${ }^{17}$

\section{$4 \quad$ The Cradle of Mankind}

As his early publications indicate, the first of Wigram's interests, befitting an Anglican missionary, was that into the ecclesial history and contemporary religious practices of the Church of the East. As noted above, like his fellowmissionaries he was motivated to paint the case of Assyrian orthodoxy as unambiguously as possible, for as large a public as possible. While this served ecumenical interests, especially of those in Great Britain that advocated closer cooperation with the Eastern Orthodox Churches, it also endangered cooper-

ure because of his wartime incarceration in Istanbul. After the war, both the manuscript and his notes had been lost. Wigram rewrote the dissertation and re-submitted it to a different committee, which again accepted it. With the help of F.C. Burkitt, who was also part of the committee, it was published in 1923. Remarkably, Burkitt reviewed it (largely positively) in The Journal of Theological Studies 26, no. 104 (1925): 427-431, reading it as an address not only to a Western public, but also to the patriarch of the Church of the East, in order to smooth relations between the two Syriac churches. Burkitt, 428.

16 On the Semele massacre, see Donabed, Reforging a Forgotten History; R.S. Stafford, The Tragedy of the Assyrians (London: George Allen \& Unwin LTD, 1935); Khaldun S. Husry, "The Assyrian Affair of 1933," Int. J. of Middle East Studies 5, no. I (1974): 161-176, and no. II: 344-36o; Sami Zubaida, "The Fragments Imagine the Nation: The Case of Iraq," Int. J. of Middle East Studies 34, no. 2 (2002): 205-215; H.L. Murre-van den Berg, "Light from the East (1948-1954) and the De-Territorialization of the Assyrian Church of the East," in Religion beyond its Private Role in Modern Society, eds. W. Hofstee and A. van der Kooij (Leiden: Brill, 2013), 115-134. See also Robson, States of Separation.

Coakley, The Church of the East, 356-6oo. 
ation with the same churches, because many were not too keen on admitting Assyrians to their fold — or at least demanded changes in their liturgy that the Anglican missionaries had been hesitant to put pressure on. ${ }^{18}$ Notably, according to Wigram the main reason for the ongoing schism and mutual misunderstandings does not lie in Church-of-the-East theology as such, but in its failed attempts to harmonize "Western" and "Oriental", or better "Greek" and "Semitic", modes of thinking, rather than understand and value each of them for their own sake. According to him, separation and distinction are to be preferred, rather than mixing and confusing. ${ }^{19}$

His intimate knowledge of Assyrian life led him to describe in lively detail ecclesial and religious practices that earlier scholars tended to ignore. He notes "magic", i.e., practices with amulets and other objects, "aboriginal tree-worship", "faith-healing" of "lunatics" in enclosed quarters, rituals at saints' shrines to further pregnancies, and animal sacrifice at yearly festivals. ${ }^{20}$ Though there is always a hint of condescension, Wigram writes with sympathy about the practices that he thought served a purpose in the religious world of the Assyrians. The same mix of condescension and sympathy suffuse his description of similar religious practices among Yezidis, Jews, and Muslims. Although the superiority of Christianity is never questioned, Wigram acknowledges that religious practice is much the same among all of those in the region. ${ }^{21}$ This is one of the reasons why it is not European Christianity that should convert Muslims, but rather "Christianity preached as the Asiatic faith which it really is". To what extent these vernacular religious practices are part of that "Asiatic faith" is left unsaid, but Western missions, Wigram asserts, should primarily be about "uplifting of the native Christians", not about converting Muslims. ${ }^{22}$

However, a careful reading of The Cradle of Mankind alongside An Introduction suggests that Wigram's interest in the Assyrians was grounded not

18 Coakley, The Church of the East, 134-144. On Wigram's mostly negative evaluation of the Russian missions in Urmia, see Coakley, The Cradle, 203, 208.

19 Wigram, An Introduction, 266; Wigram, The Cradle of Mankind, 86.

$20 \quad$ Wigram, The Cradle of Mankind, 205, 306-307, 326-329, 335-337.

21 See especially his description of the Yezidis, the so-called "Devil-worshippers". Wigram, The Cradle of Mankind, 87-110.

22 Wigram, The Cradle of Mankind, 205. This cautious view on "Muslim missions" was held against him in an otherwise positive review of The Cradle of Mankind by Margaret G. Brooke, in International Review of Mission 4, no. 1 (1915): 158-159. A similar point was made by Ruth Rouse who reviewed the volume for The Muslim World 4, no. 4 (1914): 434: "The book is neither a missionary book nor a book on Islam, except incidentally, but the authors hold strong views on the need for the regeneration of the Oriental Churches as a preliminary to the evangelisation of the Moslim world." 
only in his ecumenical ethos, but also in an interpretation of the region as one of the origins of Western civilization, "the very fons et origo of our IndoEuropean ancestors" - indeed, the "cradle" from which European civilization took much of what makes it important-while at the same time being a living illustration of Europe's past. ${ }^{23}$ This "living illustration" consisted of the detailed ethnography of life in Kurdistan embedded in historical and geographical excurses. ${ }^{24}$ In this, Wigram and his brother were very much part of the emerging evolutionist views of the time. These not only concerned Darwinian views of the history of biological life in general and humans in particular, but also the evolution of culture as proposed in the first works of the emerging field of Anthropology. The work of Edward Burnett Tylor in particular may have inspired Wigram, in its combination of historical, linguistic, biological, and ethnographic approaches. ${ }^{25}$ In turn, these evolutionist anthropological models also strongly influenced the interpretation of history more generally, and Wigram shared Tylor's idea of the evolution of "civilizations". Northwestern European civilization, rooted in Greek and Latin classical culture was considered the most evolved, with others, as yet, lagging behind for historical, geographical, or cultural reasons. This evolutionary view, therefore, naturalized European and British civilizations as the most suited to rule the world. At the same time, it allowed for campaigning for modernization and development of those considered more backward, because in the end all human culture originates from the same source, and thus all are able to reach the same level. Within the confines of this rather broadly accepted civilizational scheme, Wigram started to construct a well-documented "classical" history for the Assyrians harking back to pre-Roman and pre-Greek days, thereby allowing them to be seenand see themselves - as one of the sources rather than a later offshoot of the great river of civilization. ${ }^{26}$

23 Wigram, The Cradle of Mankind, vii-viii.

24 This was particularly liked by the reviewers, see (the anonymous) P.M.s. in Journal of the Royal Asiatic Society of Great Britain and Ireland (1914): 1140-1141 and the anonymous reviewer in the Bulletin of the American Geographical Society 47, no. 3 (1915): 219, who notes that "the authors find great interest in the society, no matter what its creed, and draw parallels with the Highlanders of Scotland."

25 Edward Burnett Tylor, Anthropology: An Introduction to the Study of Man and Civilization (London: Macmillan and Co., 1881/1896).

26 On this topic more broadly, see Mark Bradley, ed., Classics and Imperialism in the British Empire (Oxford: OuP, 2010). Note that such classical pedigrees were developed and appropriated by many other groups at the time, most explicitly so among the Maronites, see Asher Kaufman, Reviving Phoenicia: The Search for Identity in Lebanon (London \& New York: I.B. Tauris, 2002). 
This evolutionary reading of the Middle East sits comfortably with older Orientalist tropes about the region, and the Wigrams added their share of stereotypes in describing the different groups characterized by language and religion. Christians usually are seen as higher on the civilizational scale than Muslims, while what in European eyes are considered negative traits (internal divisions and population mixture) are interpreted as the negative results of longstanding Turkish rule. ${ }^{27}$ Taking these negative aspects of Turkish rule as inevitable, the Wigrams' Orientalist gaze mostly focusses on the romantic and "picturesque" aspects of it all, comparing life in the Kurdish mountains to that of the Scottish highlands: rough and dangerous, but also strong, chivalrous, and amenable to improvement and progress. ${ }^{28}$

Like in other works describing the Middle East for a Christian public at home, Wigram and his brother exploit specific Christian interpretations of the region. The "cradle of mankind" thus overlays and expands earlier missionary and theological interpretations of the region as part of the wider "Holy Land". 29 Like in the case of Palestine, this centered on the region's purported connection to biblical geography, including the location of "Paradise" or the "Garden of Eden", Noah's Ark, the land of Israel's captivity, and the home town of the prophet Nahum. It also includes references to customs and tools that hardly altered "since the days of Abraham". ${ }^{30}$ The ambiguities of mixing biblical and classical allusions are exemplified by the sketch opposite the title page. Here an image of a stark gorge in the Hakkari Mountains is entitled "The River of Eden", followed by the actual modern name of the gorge. There is no attempt to prove that this actually is one of the rivers that Genesis tells us flew out of Paradise, and therefore the associations elicited by the image plus caption may as well interpreted as an indication of the story of universal human origins in the rugged mountains of Kurdistan rather than that of a precise location of the biblical narrative. ${ }^{31}$

27 Wigram, The Cradle of Mankind, 8o-81.

28 E.g., Wigram, The Cradle of Mankind, v, viii, 67, 330, 343, 194-195; Wigram, The Assyrians, 208.

29 Heleen Murre-van den Berg, "William McClure Thomson's The Land and the Book (1859): Pilgrimage and Mission in Palestine," in New Faith in Ancient Lands: Western Missions in the Middle East in the Nineteenth and Early Twentieth Centuries, ed. Heleen Murre-van den Berg, scm 32 (Leiden: Brill, 20o6), 43-63. Wigram, The Cradle of Mankind, vii, 22-23, 26, 81-82, 84-85, 116-117, 187, 235, 264, 304, 335337 .

31 Wigram, The Cradle of Mankind, ii: "The River of Eden (The Zab entering the Tyari Gorges). The view downstream from the mouth of the Ori valley, a little above Tal. The distant snow peak is Ghara Dagh on the southern side of Tkhuma." 
This evolutionist and universalist context puts Wigram's detailed attention for popular religious practices in a different perspective. The way these are described not necessarily reflect the interest of the missionary reformist who seeks to eradicate (slowly if needed) the remains of pre-Christian superstitions among his flock, but more those of an anthropologist who sees these religious beliefs and practices as authentic be it outdated forms of religion, "fossils" that teach historians and theologians alike what used to be shared among earlier peoples all around the world, including those of Europe. According to Wigram, the region is particularly rich in such fossils: "Nearly every form of religion which has yet been known to man seems at some time or other to have struck root in the soil of Mesopotamia; and there are but few of the number that have left no stumps or fossils to remind us of the days when they were yet flourishing in their pride."32 And further on: "No fossiliferous strata preserve the forms of past ages more thoroughly than does the corporate mind of the living East; though it is often hard to extract the fossils, and harder to ascertain their true significance". 33

\section{Our Smallest Ally?}

Among these fossils whose "true significance" needs to be discovered, the Assyrian Church takes pride of place. The title page, opposite the "River of Eden" photograph, features the vignette of a priest in profile, which is repeated on the cover of the book. ${ }^{34}$ Though the image seems designed not to refer to a specific person, the priest later on in the volume is identified as "the late Qasha Khoshaba, who might have been a reincarnation of Sargon". ${ }^{35}$ The image on the title page thus not only gives away the Assyrians as the main topic of The Cradle, but it also links their contemporary importance to what many believed to be their forbears, the Assyrians of old. Wigram, different from some of his missionary colleagues, was among the early adopters of the name "Assyrian" for the Christians of the Church of the East. ${ }^{36}$ Nevertheless, in his earlier pub-

\footnotetext{
32 Wigram, The Cradle of Mankind, 88.

33 Wigram, The Cradle of Mankind, 233-234.

34 The en profile image is another implicit reference to the early anthropology of Edward Tylor, cf. Tyler, Anthropology, 2.

35 Wigram, The Cradle of Mankind, 112, notes (similarly, 276); note that the same (now full) portrait, with a matching image of King Sargon from an ancient Assyrian image, is given in W.A. Wigram, The Assyrians and their Neighbours (London: G. Bell \& Sons, 1929), 179 .

36 For the early history of the usage of this term, see Becker, Revival and Awakening. The Arch-
} 
lications he remained cautious: in An Introduction the only explicit argument for its use is the fact that other names are even less appropriate, though "there is no historical authority for this name". ${ }^{37}$ In The Cradle he introduces the issue lightly, referring to "their own traditions" in which Assyrians claim that they are the descendants of "the ancient Assyrians" rather than making the case for it himself. ${ }^{38}$ Only the use of the image of priest Khoshaba with its reference to Sargon can be read as an implicit argument in favour of the Assyrian identification. ${ }^{39}$

Almost twenty years later, when The Assyrians and their Neighbours was published, things had changed. In Wigram's book of 1929 the identification of the modern-day Assyrians with the ancient Assyrians is very explicit, circling around the concept of "stock" - a term which he used only a few times in The Cradle in the sense of referring to a group with common ancestry, mostly parallel with "race". ${ }^{0}$ In The Assyrians racial thinking had become one of the main themes, most explicitly so in the first chapter in which "the national stocks in Mesopotamia" are being carefully distinguished from each other and organized hierarchically, with the Assyrians on top as one of the most ancient and honorable in the region, and Arabs and Kurds further down the scale, setting the scene for a racialized interpretation of the inhabitants of the region. ${ }^{41}$ In a later chapter, he discusses the proposed link between the ancient and modern Assyrians more extensively, putting forward linguistic, physical, and ethnographic arguments, in line with Tylor's anthropological methods, though never quite committing himself to it fully. ${ }^{42}$ Though putting himself squarely at the side of those who believe in an unbroken line between the Assyrians of old and those of the present day, he admits that contemporary Assyrians are not of "unmixed blood", even if their strict marriage laws allowed them to keep "a purity of blood

bishop of Canterbury's mission used this name almost from the beginning, see Coakley, The Church of the East, 65, 147-148, 285 .

37 Wigram, An Introduction, vii.

38 Wigram, The Cradle of Mankind, 112.

39 Wigram, The Cradle of Mankind, 344-346 (about Mosul/Nineveh).

40 At least one reviewer, J. Lewy, in Orientalistische Literaturzeitung 35 (1932): 576 reacted negatively to this "Assyrian identification", although he liked the final chapters on the current state of the nation.

41 Wigram, The Assyrians, vii, 1-14. Note Wigram's rather critical stance towards the Armenians, perhaps reflecting views among Assyrians and Westerners in Eastern Turkey at the time, suggesting that some of the Armenian parties were at least partly to be blamed for the accusations of disloyalty from the Turkish government. Some of his accusations remind the reader of anti-Semitic tropes, cf. The Assyrians, 9 ("Unable either to command or obey, the Armenian was forever intriguing against ...").

Wigram, The Assyrians, 178-193; Tylor, Anthropology, $152 \mathrm{ff}$. 
not known in the West", combining his understanding of a somewhat messy historical past with his preference for pure and unmixed cultures. ${ }^{43}$ Wigram thus provides the Assyrians with a deep historical pedigree, a valid claim on lands in Iraq and Eastern Turkey, and a well-described ethnoreligious identity that is as romantic and picturesque as it is military and imperial, on a par with other nations of the world. And so the Assyrians become worthy objects for the attempts of the British Mandate government in cooperation with the League of Nations to find them new homes. ${ }^{44}$ These resettlement plans, part of a much larger attempt of the colonial powers to redraw boundaries and resettle populations towards clearly identifiable and distinct nations conforming as much as possible to the ideal of religiously, linguistically, and ethnically homogeneous populations. ${ }^{45}$ Whereas Wigram did not invent the Assyrians as a separate group, his writings contributed significantly in elaborating and solidifying what Assyrian identity might mean not only for Assyrians on the ground and abroad, but also for the British public as much as its policy makers, colonial rulers, and military.

According to Wigram, one aspect of that newly emerging identity is the Assyrians' enduring global importance in the "museum of ethnology and of religious science" that is this land "with six thousand years of continuous history". ${ }^{46}$ As "a strange survival" their "ancient and fossilized Church" has "preserved ecclesiastical rites and ceremonies which have either perished altogether elsewhere, or else have survived only in almost unrecognizable form". ${ }^{47}$ These older forms of religion and church may remind Christians and others everywhere of our common origins, "human nature [being] much the same all the world over" ${ }^{48}$ However, in the work of Tylor, in which such fossilized sur-

43 Wigram, The Assyrians, 167-168, 179, 184-185; see also earlier Wigram, The Cradle of Mankind, 83-84.

44 For the strong ties between Great Britain and the League of Nations, see Mark Mazower, Enchanted Palace: The End of Empire and the Ideological Origins of the United Nations (Princeton: Princeton University Press, 2009).

45 Robson, States of Separation; for contemporary documentation, see e.g., "The Settlement of the Assyrians: A Work of Humanity and Appeasement," League of Nations, Geneva (1935), http://www.atour.com/government.

$46 \quad$ Wigram, The Assyrians, 11.

47 Wigram, The Assyrians, 177.

48 Wigram, The Cradle of Mankind, 309. This is the only place where Wigram quotes Tylor's Anthropology, but it is clear that his work has infused much of Wigram's ideas on human history and culture. For the idea of "survivals", see Tylor, Anthropology, 15-16, 411; for a discussion of Tylor's work on religion, see Ivan Strenski, Thinking About Religion: An Historical Introduction to Theories of Religion (Oxford: Blackwell Publishing Ltd., 2006), 91-116, mostly based on Tylor's earlier work (Religion in Primitive Culture, 1873). 
vivals play an important role, the term "survival" mainly refers to things that no longer constitute a vital part of contemporary society. Rereading Wigram's work with this in mind, his use of the term survival in his post-war works suggest that he became even less optimistic about the chances for modern Assyrians to transcend the role of "a strange survival" than he had been before the war. ${ }^{49}$ The Assyrians had become an object of study rather than a living reality. In 1929, indeed, much of what was picturesque had disappeared and the situation had changed for the worst, leaving little hope for the kind of settlement that would ensure national survival and further development. Wigram writes:

If the nation is to survive at all, it must be as no more than an element in the Kingdom of Iraq, where its Church life may be respected, but must alter in new conditions, and any political individuality that it had preserved through the ages must of necessity be dissolved in the life of a larger whole.

One may regret the passing of a picturesque and ancient survival, but there is no means of preserving it. ${ }^{50}$

With these lines that merge the political, the cultural-anthropological, and the personal, Wigram refrains from actively seeking to preserve the Assyrian nation as it was before the war, but rather to put it on record by describing their religion and traditions. That is what needs to be preserved in order to better understand the history of Christianity and that of religion more generally, with the Assyrians' political fate being subordinated to the higher demands of empire.

The most painful ambiguity of Wigram's work, therefore, is that his efforts to understand the Assyrians as a nation in their own right, with a historic and religious pedigree that puts them in the premier league of nations, at the same time delegates them to a place in a museum rather than entitle and strengthen them to fully participate in the living and ever-developing reality of the Iraq and the Middle East more generally. This also suggests that Wigram's ongoing advocacy, in which he urges the British to take responsibility for the Assyrians' fate, is no more than an afterthought in trying to pick up the pieces in support of those that survived. Resettlement and incorporation in British Man-

49 See the rather cautious pre-war final lines of The Cradle of Mankind, $35^{8}$ on the future of the Assyrians: "May it be an omen that the date-palm (Babylon's ancient and beautiful emblem of fertility and life) is now springing up anew in every trench of the excavations at Babil". 
date Iraq, including them in the military, providing work and sustenance, all of that cannot, at least according to Wigram's reading of history, contribute to the Assyrians' re-emergence as a nation among the nations.

Wigram's work embodies all the ambiguities of late imperial and colonial missionary involvement. In it, a genuine interest in the history and current situation of "the Assyrians and their neighbours" is deeply implicated in colonial re-interpretations in service of geopolitical and military interests in the region. This ambiguity parallels the missionary activities as such, in their mixture of long-term processes of mutual learning, inter-Christian aid and humanitarian assistance, in the context of personal involvement, albeit sometimes very critically so, with the objectives and larger aims of British imperial and colonial interests in the region. The missions among the Assyrians, as shown by Becker with regard to the American mission and by Coakley with regard to the Anglicans, were also implicated in the emergence of a nationalist reading of Assyrian history-not so much because the missionaries enforced an alien concept of ethno-religious nationalism on unwitting Assyrians, but because discussions of self and nation, of religion and culture, and of rankings of nations and religions in relation to each other, were part and parcel of the intellectual discussions of the day - in Europe, the Americas, Russia, and in the Middle East. Missionaries, who for many Assyrians and other Christians in the periphery of empires provided the first and most important window on larger intellectual trends, thus became a primary source for new communal understandings among the emerging nations of the Middle East. Vice versa, the missionaries were among the first interpreters of non-Western cultures and religions to Western audiences, introducing radically different people with radically different practices and beliefs as part of what indeed was considered a common humanity, even if they mostly were interpreted as ranking lower on generally accepted scales of civilizations. These recursive dynamics, of explaining empire and the wider world to readers in the west, of personal attachment to new groups outside traditional Western allegiances, with ongoing loyalty to the demands of empire and Western global dominance, characterize Wigram's publications on the Assyrians.

In this, he is a representative of a typically British take on these interactions between the local and the global, the Western and the Eastern churches, the past and the present. His commitment to the integration of the Assyrian church into the ecumenical fellowship of churches was part of a wider 
Anglican commitment to playing the role of broker between Western and Eastern churches. Wigram tried to smooth the way for the Assyrian Church that tended to be excluded from the emerging ecumenical consensus of the early 2oth century in ways that American Protestant and French Dominican missionaries were hardly interested in. Wigram also, more explicitly so than his Presbyterian and Dominican colleagues, was implicated in the colonial and imperial aspects of Western presence in the region. While he came to despair independent nationhood of the Assyrians and was critical of British policies in this regard, he kept seeing them as a useful tool for British colonial rule in the region.

Different from Protestant or Catholic missionary authors, Wigram's advocacy for the Assyrians was grounded in a grand historical scheme that made them worthy of British attention. It was their Christian credentials as an ancient church that faithfully kept some of the oldest rituals and beliefs of global Christianity that contributed to this. These Christian credentials, however, were rooted in a yet more prestigious classical world. Wigram positions the Assyrians as part of one of the oldest civilized nations that emerged in the "cradle of civilizations" that is Mesopotamia, a nation that, despite strings of oppressive and uncivilized governments through the ages, had retained some of that preIslamic and pre-Turk purity that the region as a whole had lost or perhaps never quite had.

His eloquent advocacy had little impact on the position of the Assyrians in and from Iraq. Their integration into the Iraqi state failed miserably and most plans for resettlement fell through. The community became divided among those that preferred to make the most of their new Iraqi homes, those that migrated to Europe, Latin America, and the United States, and the small number that from the 193os onwards made their homes in northeast Syria, along the river Khabur. The implicit and explicit humanitarianism of Wigram's advocacy, therefore, yielded no concrete results, not for the Assyrians as a people, not for the Iraqi or Syrian states, and not for individual Assyrians. What his books and pamphlets did achieve, however, was to put the Assyrians in the historical limelight, undergirding their claims to be allowed to the concert of nations as a nation in their own right, with a combined classical-Christian pedigree that few in the region could match. Whereas his literary advocacy was addressed first and foremost to a Western audience, it was among Assyrians that his interpretation of the nation was to have the most long-lasting effects. His books have contributed to the emergence of an Assyrian nation, of the creation and dissemination of concepts of nationhood among Assyrians and non-Assyrians alike. It is by way of these unintended consequences that Wigram has contributed to the survival of a community that was threatened with extinction. 


\section{Bibliography}

\section{Books and Pamphlets by W.A. Wigram}

Wigram, W.A. The Doctrinal Position of the Assyrian or East Syrian Church. London: SPCK, 1908.

Wigram, W.A. An Introduction to the History of the Assyrian Church: Or the Church of the Sassanid Persian Empire, 100-640. London: SPCK, 1910.

Wigram, W.A. The Cradle of Mankind: Life in Eastern Kurdistan. London: A. \& C. Black, 1914; 2nd ed. London: A. \& C. Black, 1922.

Wigram, W.A. Intercommunion with the Assyrian Church. London: Faith Press, 1920.

Wigram, W.A. Our Smallest Ally: A Brief Account of the Assyrian Nation in the Great War. London: SPCK; New York: Macmillan, 1920.

Wigram, W.A. The Assyrian Settlement. London: SPCK, 1922.

Wigram, W.A. The Cradle of Mankind: Life in Eastern Kurdistan. 2nd ed. London: A. \& C. Black, 1922.

Wigram, W.A. The Separation of the Monophysites. London: Faith Press, 1923.

Wigram, W.A. The Assyrians and Their Neighbours. London: G. Bell \& Sons, 1929.

Wigram, W.A. Hellenic Travel: A Guide. London: Faber \& Faber, 1947.

\section{Other Publications}

Austin, H.H. The Baqubah Refugee Camp: An Account of Work on behalf of the Persecuted Assyrian Christians. London: The Faith Press, 1920.

Becker, Adam. Revival and Awakening:Christian Mission, Orientalism, and the American Evangelical Roots of Assyrian Nationalism (1834-1906). Chicago: Chicago University Press, 2015.

Bradley, Mark, ed. Classics and Imperialism in the British Empire. Oxford: OUP, 2010.

Brooke, Margaret G. Review of The Cradle of Mankind, by W.A. Wigram. International Review of Mission 4, no. 1 (1915): 158-159.

Burkitt, F.C. Review of The Separation of the Monophysites, by W.A. Wigram. Journal of Theological Studies 26, no. 104 (1925): 427-431.

Coakley, J.F. The Church of the East and Church of England: A History of the Archbishop of Canterbury's Assyrian Mission. Oxford: Clarendon Press, 1992.

Coakley, J.F. "Wigram, William Ainger (1872-1953)." In Oxford Dictionary of National Biography, edited by Lawrence Goldman. Oxford: oup, 2004. Available via http:// www.oxforddnb.com/view/article/58374.

Donabed, Sargon George. Reforging a Forgotten History: Iraq and the Assyrians in the Twentieth Century. Edinburgh: Edinburgh University Press, 2015.

Gaunt, David. Massacres, Resistance, Protectors: Muslim-Christian Relations in Eastern Anatolia during World War I. Piscataway, NJ: Gorgias Press, 2006.

Hellot-Bellier, Florence. Chroniques de massacres annoncés: Les Assyro-Chaldéens d'Iran en du Hakkariface aux ambition des empire, 1896-1920. Paris: Geuthner, 2014. 
Husry, Khaldun S. “The Assyrian Affair of 1933." Int. J. of Middle East Studies 5, no. I (1974): 161-176, and no. II: 344-36o.

Joseph, John. The Modern Assyrians of the Middle East: Encounters with Western Christian Missions, Archeologists, and Colonial Powers. ScM 26. Leiden: Brill, 200o, revised.

Kaufman, Asher. Reviving Phoenicia: The Search for Identity in Lebanon. London \& New York: I.B. Tauris, 2002.

League of Nations. "The Settlement of the Assyrians: A Work of Humanity and Appeasement." Geneva, 1935. http://www.atour.com/government.

Lewis Shedd, Mary. The Measure of a Man: The Life of William Ambrose Shedd, Missionary to Persia. New York: George H. Doran, 1922.

Lewy, J. Review of The Cradle of Mankind: Life in Eastern Kurdistan, by W.A. Wigram. Orientalistische Literaturzeitung 35 (1932): 576.

Mazower, Mark. Enchanted Palace: The End of Empire and the Ideological Origins of the United Nations. Princeton: Princeton University Press, 2009.

Mueller, H. "The League of Nations, A-Mandates and Minority Rights during the Mandate Period in Iraq (1920-1932)." In Modernity, Minority, and the Public Sphere:Jews and Christians in the Middle East, edited by S.R. Goldstein-Sabbah and H.L. Murrevan den Berg, 258-283. LSIS 4. Leiden: Brill, 2016; Open Access; Dor: 10.1163/9789oo4 323285 .

Murre-van den Berg, Heleen. From a Spoken to a Written Language: The Introduction and Development of Literary Urmia Aramaic in the Nineteenth Century. De Goeje Fund 28. Leiden: NINO, 1999 .

Murre-van den Berg, Heleen. "William McClure Thomson's The Land and the Book (1859): Pilgrimage and Mission in Palestine." In New Faith in Ancient Lands: Western Missions in the Middle East in the Nineteenth and Early Twentieth Centuries, edited by Heleen Murre-van den Berg, 43-63. SCM 32. Leiden: Brill, 2006.

Murre-van den Berg, H.L. "Light from the East (1948-1954) and the De-Territorialization of the Assyrian Church of the East." In Religion beyond its Private Role in Modern Society, edited by W. Hofstee and A. van der Kooij, 115-134. Leiden: Brill, 2013.

Murre-van den Berg, Heleen. "Writing Assyrian History: The Military, the Patriarch and the British in Yaqu bar Malek Ismael's Assyrians in Two World Wars (Tehran 1964)." In Sayfo 1915: An Anthology of Essays on the Genocide of Assyrians/Aramaeans during the First World War, edited by Shabo Talay and Soner O. Barthoma, 213-23o. Gorgias Eastern Christian Studies 5o. Piscataway, NJ: Gorgias Press, 2018.

O'Flynn, Thomas S.R. The Western Christian Presence in the Russias and Qājār Persia, c.1760-c.1870. SCM 47. Leiden: Brill, 2017.

Project Canterbury. "Intercommunion with the Assyrian Church by William Ainger Wigram, D.D.” Accessed March 30, 2018. http://anglicanhistory.org/orthodoxy/wigr am/assyrian192o.html.

Robson, Laura. States of Separation: Transfer, Partition, and the Making of the Modern Middle East. Stanford: University of California Press, 2017. 
Rouse, Ruth. Review of The Cradle of Mankind, by W.A. Wigram. The Muslim World 4, no. 4 (1914).

Stafford, R.S. The Tragedy of the Assyrians. London: George Allen \& Unwin LTD, 1935. Strenski, Ivan. Thinking About Religion: An Historical Introduction to Theories of Religion. Oxford: Blackwell Publishing Ltd., 2006.

Ticktin, Miriam. "Humanity as Concept and Method: Reconciling Critical Scholarship and Empathetic Methods." Review of Bread from Stones: The Middle East and the Making of Modern Humanitarianism, by Keith David Watenpaugh. Comparative Studies of South Asia, Africa and the Middle East 37, no. 3 (2017): 6o8-613.

Tylor, Edward Burnett. Anthropology: An Introduction to the Study of Man and Civilization. London: Macmillan and Co. 1881, $1896^{2}$.

Watenpaugh, Keith David. Bread from Stones: The Middle East and the Making of Modern Humanitarianism. Berkeley: University of California Press, 2015.

Zubaida, Sami. "The Fragments Imagine the Nation: The Case of Iraq." Int. J. of Middle East Studies 34, no. 2 (2002): 205-215. 
- 978-90-04-43453- 0

Downloaded from Brill.com04/26/2023 01:14:44PM via free access 
PART 3

Best Practices 
- 978-90-04-43453- 0

Downloaded from Brill.com04/26/2023 01:14:44PM via free access 


\title{
Missionary Hubris in Colonial Algeria? Founding and Governing Christian Arab Villages 1868-1930
}

\author{
Bertrand Taithe
}

The historiography of missionary work in the French empire often concentrates on the sub-saharan African empire, the pacific islands, or Madagascar. In all these contexts the collusion of state and Catholic Church in resisting Protestant and non-French incursions can be demonstrated over the long run even if these relations were not without their difficulties at times. ${ }^{1}$ In contrast, historians have long identified the misgivings of French military ${ }^{2}$ leaders concerned with the risks that overt proselytizing might represent in established Muslim societies. This cautious attitude characterized the fine balancing act undertaken by the French state in Algeria. ${ }^{3}$ The colony, which was simultaneously one of the most difficult spaces to control over the period 18301871 and the one territory overseas destined to become part of France, was a prime example of the political tensions arising from missionary activities. From 1868 until 1939, French missionaries in Algeria played a significant role in challenging the Second Empire and the Third Republic. In turn undermining the Royaume Arabe separate development ideology of Napoleon III's regime ${ }^{4}$ and challenging the increasingly racialized segregation policies of mostly anti-

1 See Sarah E. Curtis, Civilizing Habits: Women Missionaries and the Revival of French Empire (Oxford: Oxford University Press, 2010); James-Patrick Daughton and Owen White, In God's Empire: French Missionaries and the Modern World (Oxford: Oxford University Press, 2011); for a good discussion of religious conflicts in the empire, J.P. Daughton, An Empire Divided: Religion, Republicanism and the Making of French Colonialism, 1880-1914 (Oxford: Oxford University Press, 2006); Robert Aldrich, The French Presence in the South Pacific, 1842-1940 (London: Macmillan, 1990). There were of course French protestant missionaries active in the French and British empires. See Jean-François Zom, Le Grand Siècle d'une mission protestante: La mission de Paris de 1822 à 1914, 2nd ed. (Paris: Karthala, 2012).

2 This is well documented for the French Sudan. See Joseph-Roger de Benoist, Église et Pouvoir Colonial au Soudan Français (Paris: Karthala, 1987).

3 Oissila Saaidia, Algérie colonial. Musulmans et chrétiens: le contrôle de l'Etat (1830-1914) (Paris: CNRS, 2015); Dominique Urvoy, "Les conversions au catholicisme en Algérie," Outre-Terre 2015/4, no. 45 (2015): 249-255.

4 Annie Rey-Goldzeiguer, Le Royaume arabe, la politique algérienne de Napoléon III (Algiers: Société Nationale d'Édition et de Diffusion, 1977); Georges Spillmann, Napoléon III et le roy-

(C) BERTRAND TAITHE, 2020 | DOI:10.1163/9789004434530_008

This is an open access chapter distributed under the terms of the CC BY-NC 4.O license. 
clerical republicans, missionaries sought to present an alternative vision of what Algeria might become should it be converted to Catholicism. In many ways these missionary aspirations matched the colonial humanitarianism that Alan Lester described in relation to the British empire's treatment of aboriginal people in the antipodeans. In this mode of governmentality, which was developed earlier in the 19th century, the treatment of native Australians offered the possibility of protection at the expense of their genuine human rights or the more predatory economic rights of the settlers. Lester argues that this mode of colonial governmentality attempted to find a humanitarian way which would resist revolutionary individualism and some of the most egregious consequences of capitalism. ${ }^{5}$ Missionaries in North Africa sometimes made themselves the comparison between Arabs and aborigines, and they too sought to build a mode of governance which might offer a path to social and cultural conversion to a profoundly anti-revolutionary way of being French.

The primary spokesperson of this ambitious dream was Mgr Lavigerie who, together with his missionary society, the White Fathers, sought to exploit the crises of the late 186os to articulate afresh their vision of a new society. ${ }^{6}$ Though successful in setting up some model villages and modest Christian communities under their paternalist governance, the Republican regime proved much more effective in containing the political threat Catholic Arabs might represent. This chapter will show how, over a long period, a hubristic dream became reduced to a political and social anomaly in the increasingly racialized politics of Colonial Algeria.

The paradox of missionary presence in French colonial Algeria could not be better illustrated than through the extraordinary homage that the republicans offered the Archbishop of Carthage Charles Lavigerie in 1892. Arguably the most significant prelate in the French empire by the time of his death, Charles Martial Allemand Lavigerie, Cardinal since 1882, Archbishop of Algiers since 1867, had only two years before his death signified the potential acceptance of the Republic by the Catholic Church in a famous address to the French navy. ${ }^{7}$ His funerals involved the military and civilian authorities united in honouring

aume arabe d'Algérie, Paris, Travaux et mémoires de l'Académie des sciences d'outre-mer, nouvelle série 3 (Paris: Académie des Sciences d'Outre-mer, 1975).

5 Alan Lester and Fae Dussart, Colonization and the Origins of Humanitarian Governance: Protecting Aborigines across the Nineteenth Century British Empire (Cambridge: Cambridge University Press, 2014).

6 For a history of the White Fathers see Jean-Claude Ceillier, Histoire des missionnaires d'Afrique (Pères Blancs), de la fondation par Mgr Lavigerie à la mort du fondateur (1868-1892) (Paris: Karthala, 2008).

7 Xavier de Montclos, Lavigerie le Saint-Siège et l'Église: De l'avènement de Pie IX à l'avènement 
him. His remains were the object of processions and his coffin was taken by the French Navy to his resting place in Tunis.

What were they celebrating? The man who had ruled with an iron fist the Catholic Church in Algiers, Constantine, and Tunisia? The man who had brought about, through a single toast at a dinner party, the promise of a ralliement of the Catholic church to the republic? The opponent of the military regime and of the Royaume Arabe who did not fear from engaging with republicans in order to challenge MacMahon's restrictions on commercial and agricultural developments? The international crusader against African slavery and the Zanzibarian slave trade? The man of the Alliance Française? Or the missionary innovator whose Société des Missionnaires d'Afrique now made inroads across the continent. Whatever it was Lavigerie incarnated it was controversial. One point detractors and admirers could agree on: Lavigerie had transformed the Catholic Church in North Africa and its fortunes. Though extremely diverse his career followed one significant thread, the desire to force French colonial authorities to grant full apostolic freedom in Muslim territories in order for the Church to renew its pastoral authority.

Throughout his life and since his arrival in Algeria in 1868, in the midst of a famine, ${ }^{9}$ Lavigerie had challenged the notion that Muslim societies could not be converted or that ardent missionary activity should be circumscribed to existing Christian communities. ${ }^{10}$ Inheriting a near bankrupt institution, ${ }^{11}$ Lavigerie demonstrated a most unusual businesslike approach to restoring the fortunes of the Catholic Church, sometimes at the expense of his competitors including bishops of neighbouring dioceses. ${ }^{12}$ As a result of his many ventures and international fundraising - the Algerian church experienced in 30 years a massive increase of its income, a flourishing of its business interests,

de Léon XIII, 1846-1878 (Paris: de Boccard, 1965); François Renault, Le Cardinal Lavigerie (Paris: Fayard, 1992).

8 Much of the historiography of Algeria has tended to focus on this specific question e.g. Charles André Julien, Histoire de l'Algérie Contemporaine vol. 1 (Paris: Presses Universitaires de France, 1986), 441-443; Marcel Émerit, "Le problème de la conversion des musulmans d'Algérie sous le Second Empire: Le conflit entre Mac-Mahon et Lavigerie," Revue Historique 223, no. 1 (1960): 63-84.

9 Djilali Sari, Le désastre démographique (Algiers: Société Nouvelle d'Édition et de Diffusion, 1982).

10 Abbé Bellarmin-Vincent Burzet, Histoire des désastres de l'Algérie, 1866-1867-1868: Sauterelles, tremblement de terre, choléra, famine (Algiers: Garaudel, 1869).

11 Archives Générales des Missionnaires d'Afrique (AGMAfr), A16, abbé Hodard, Introduction aux ouvres de Mgr Pavy (Algiers, nd).

12 This is well documented for Mgr de Las Cases, see Henri Barthès, Monseigneur de las Cases, évêque de Constantine (Montpellier: Presses Universitaires de Paul Valéry, 1980). 
the development of networks of charities, and a much greater density of religious activities providing dispensaries, schools, asylums for the elderly and orphans.

In this he was not alone since many bishops also innovated in making the Catholic wealthy once again but they usually benefited from the support of wealthy donors-in short supply in Algeria. Lavigerie thus had to internationalize his cause and make it emblematic of a militant Church going global. The Catholic Church in North Africa before 1868 was meant to service the spiritual needs of a thin strip of parishes populated by the very diverse "European" population of the colony. When it sought to expand its remit to the wider context, it was relentlessly opposed by military officers and in particular the notorious bureaux arabes, the embedded information offices which monitored the tribes of hinterland Algeria. ${ }^{13}$

Missionaries had been severely curtailed in their activities even though they perceived some of Algeria to be so-called "crypto Christians". The Kabyles, that is the Tamazight (Berber) speakers of Algeria, presented village communities with local civic organizations which led French administrators of the 186os to imagine them as most receptive to French civilization if not outright Christianity. ${ }^{14}$ As Patricial Lorcin and Alain Mahé have shown there was considerable ethnographic interest and depth in the making of a Kabyle myth which encouraged some priests to attempt apostolic missions in the mountains of Algeria. ${ }^{15}$ These initiatives were limited before the arrival of Lavigerie and they only grew in a very modest fashion after his installation in Algiers. Soon the reality of facing complex and resilient societies which were in 1871 one of the hotbeds of resistance to French occupation and a site of Djihad undermined any grand expansion plan.

13 Abdelmajid Hannoum, "Colonialism and knowledge in Algeria: The archives of the Arab bureau," History and Anthropology vol. 12, no. 4 (2001): 345-379; Jacques Frémeaux, Les bureaux arabes dans l'Algérie de la conquête (Paris: Denoël, 1993).

14 Adolphe Hanoteau and Aristide Letourneux, La Kabylie et les coutumes Kabyles (Paris: Imprimerie nationale, $1872-1873)$. On the religious question Hanoteau and Letourneux were very sceptical even if they stressed the parallels between village life in Kabylie and France. See Karima Dirèche, Chrétiens de Kabylie (1873-1954). Une action missionnaire dans l'Algérie coloniale (Saint Denis: Bouchène, 2004); Karima Dirèche, "Les écoles catholiques dans la Kabylie du XıX ${ }^{\mathrm{e}}$ siècle," Cahiers de la Méditerranée, 75 (2007): 17-27, available via http://journals.openedition.org/cdlm/3333.

15 Alain Mahé, Histoire de la Grande Kabylie, anthropologie historique du lien social dans les communautés villageoises (Saint Denis: Bouchène, 2001), 181-19o; Patricia M.E. Lorcin, Kabyles, arabes, français: Identités colonials (Limoges: Presses Universitaires de Limoges, 2005). 
Lavigerie nevertheless proved a great innovator and a remarkably opportunistic entrepreneur. He brought to life a range of initiatives, often without resourcing them outright and sought in the wider Catholic world support for his campaigns. His most significant success was the Société des Missionnaires d'Afrique. In the 188 os and 189 os, the society expanded mostly in sub-Saharan Africa in competition with other religious orders (such as the Spiritans). Until his death, Lavigerie ruled the missionary organization with an iron fist which contrasted with his more difficult relations with the parish clergymen of his diocese. As a missionary army, Lavigerie's society proved very resilient to the very strong anticlerical pressures exercised in Algeria. In order to avoid too much financial scrutiny, Lavigerie did not hesitate to displace his offices and training college to Malta and Rome. While the Catholic Church remained in tacit and sullen opposition to the French republic from 1870 until 189o, Lavigerie's missionaries were working closely with some of the colonial authorities despite concerns among a significant portion of the settlers. The White Fathers became the embodiment of an alliance of militarism and missionary work in the colonial landscape (with two separate examples of attempted private militia in Congo and in the Sahara) and of high colonial missionary work. ${ }^{16}$ To the point that when Catholic missionaries experienced their about-turn and considerable revision of their position in relation to the colonial regime in the 1920s, the White Fathers stood as the butt of many of criticism of what missions ought not to be.

In many ways Lavigerie had succeeded most where he was not-in Sub Saharan Africa, in France where his society was mocked but also admired and worldwide where it recruited. Arguably Algeria and the complex colonial society of the colony resisted the charisma and brutal efficiency of the cardinal. As many historians of missions in North Africa and in the Middle East have shown the task of missionary work in Dar al Islam proved difficult and contradictory. There his aspirations remained at their most hubristic, impossibly grand considering his resources and intractable in their politics to a fast changing colonial society and state.

16 Bertrand Taithe, "Missionary Militarism? The Armed Brothers of the Sahara and Leopold Joubert in the Congo," in God's Empire: French Missionaries and the Modern World, eds. James-Patrick Daughton and Owen White (Oxford: Oxford University Press, 2011), 12915 o. 
I have written elsewhere on the scale of Catholic response to the famine that affected Algeria between 1865 and $1868 .{ }^{17}$ The concept of famine itself was a hotly contested notion which remains controversial today and which Lavigerie single handedly promoted worldwide to describe the immense poverty of eastern Algeria. Throughout the events of 1868 Lavigerie challenged the French military authorities to respond to the crisis by dismantling their own regulatory framework and admitting the bankruptcy of the policies underpinning the Royaume Arabe promoted by Napoleon III. ${ }^{18}$ In particular the crisis revealed, according to Lavigerie, the fundamental lack of compassion in Muslim society. It significantly opened up the doors to more interventionist responses. In this context Lavigerie identified three groups worthy of Christian charity which were according to him either neglected or exploited in Muslim society: the elderly, divorced women, and orphans. He correspondingly opened up institutions for all three groups.

While the abandoned women represented an iconic group of gender differences between Christian and Muslim society, they were neither a large group nor one with any potential for growth. The same applied to the abandoned elderly who tended to be a small group of alienated individuals. Orphans in contrast represented a very significant constituency, a cultural blank slate with potential for further development and exemplary uses. Catholic orphanages in France had long been one of the traditional roles of the Church. These institutions, part-prison part-school, played their containment role with the support of municipal authorities and catered at a fairly basic level for the needs of a large disenfranchised community. But there was one significant innovation in the French orphanages with the the setting up in 1866 of the Apprentis d'Auteuil institution by Abbot Roussel. ${ }^{19}$ Aimed at street orphans and impoverished abandoned children, the apprentis d'auteuil intended to train and discipline children into practical skills and in basic education in order to reChristianize the working class. Orphans/apprentices would become beacons of Catholic virtue among the poor.

17 Bertrand Taithe, "Algerian Orphans and Colonial Christianity in Algeria 1866-1939," French History 20, no. 3 (2006): 240-259.

18 Léon Hugonnet, La Crise algérienne et la démocratie (Paris: Chevalier, 1868).

19 On apprentices and different modes of adoption see Yves Denéchère, "Histoires croisées des orphelins et de l'adoption," in Invisibles orphelins, ed. Magali Molinié (Paris: Autrement, 2011), available via https://halshs.archives-ouvertes.fr/halshs-o1o9159o. 
The upheaval of 1868 provided the opportunity for the Missionaires d'Afrique to gather a large cohort. Though decimated by an epidemic, some 806 children were declared orphans by the religious authorities of Algeria and became a formidable burden to shoulder. ${ }^{20}$ The scale of the rescue could only be justified on humanitarian ground on the one hand, and by a broader sociopolitical aim on the other. Lavigerie had been involved in 1860 in supporting the écoles chrétiennes au proche orient. He had a strong interest in setting up missionary work as a pedagogical enterprise. Fundamentally Lavigerie felt that the French colonial administrators and the wider settler population needed to understand that Arab Christians were not only possible but necessary for the moral redemption of the entire colony and the Arab world at large. Though many "orphans" turned out to be no such thing in the legal definition of the term, Lavigerie associated "abandonment" to orphaning and successfully resisted any prolonged attempt by Arab families to regain control of the boys and girls the Church catered for. There were voices in the Arab community challenging the diktat and the circumstances of the adoption and on April 22, 1874 the conseil general of Algiers issued a report in response to Algerian demands that the orphans be transferred to the authority of the prefect of Algiers:

It is not an ordinary situation that had made the ecclesiastical authorities the arbiter of the fate of famine orphans succoured by the voluntary gifts of Christian folks, this situation is the product of events and it seems difficult to modify it ... Mgr Lavigerie finds himself placed in the position of an adoptive father; there is established between the protector and the protected a kind of contract. ${ }^{21}$

Paternalism as governance was thus set in place through this "adoption". Rather than a metaphorical use of the concept of paternalism-a recurrent trope in any analysis of humanitarian or development practices-one here encounters a specific legal reality and a private mode of governing over the lives of hundreds of individuals. ${ }^{22}$ Over a period of twenty years this exceptional cohort represented a once in a lifetime opportunity which, contrary to the prelate's expectation, was not often renewed once the famine was over. Following the war of $1871,{ }^{23}$ Republican leaders distanced themselves from the Churchmen

\footnotetext{
$20 \quad$ AGMAfr Papiers Lavigerie B7 251.

21 AGMAfr B7 168 \& Extrait du procès verbal de la séance du 22 avril 1874.

22 See Michael Barnett, ed., Paternalism Beyond Borders (Cambridge: Cambridge University Press, 2017).

23 Colonel Robin, L'Insurrection de la Grande Kabylie en 1871 (Paris: Charles Lavauzelle, 1900).
} 
and blamed the Mokrani insurrection on the French military themselves. ${ }^{24}$ The early years of the Third Republic led to a massive dispossession of the Algerian elites, the dismantling of much of traditional society and the beginning of a process of proletarianization that lasted until independence in 1962 but, paradoxically, also a growing fear of the threats that established Muslim organizations might present to the colonial order should their monopoly be threatened. Within settler society, anti-clerical and anti-Semitic passions defined the split between moderate republicans and radicals. ${ }^{25}$ While anti-clericalism was effectively the core belief of many republicans, radicals pushed it to its paroxysmal expression. Anti-Semitism which became a trademark of Algerian politics in the 189 os was largely subservient to the vested interests of politicians opposed to moderate republicans supported by the newly enfranchised North African Jewish community. In many ways the context in which orphans who happened to be Arabs and Christians could not have been more hostile.

At the heart of the debates on Christianity in Algeria was the religious dimension of citizenship. Europeans were primarily, notionally at least, Christian in heritage if not practice. Europeans were "naturalized" as Frenchmen in one move in 1889. Jews of North Africa, Sephardic in practice, had been the object of the paternalist interventions of French Jews ${ }^{26}$ and after much lobbying, the Crémieux decree of October 24, 1870 had naturalized them in block. ${ }^{27}$ In the Algerian context Algerians were French nationals but not citizens. By naturalization one thus refers to the gaining of full rights as citizens and the commensurate loss of any specific religious status-in this instance the right to refer to Mosaic laws. As Kamel Kateb has shown, French ethnic policies developed and defined their subgroups over the first 100 years of

For a Marxist analysis of the events of $1871 \mathrm{cf}$. Mahmoud Bennoune, "Origins of the Algerian Proletaria," Middle East Report 94 (1981): 5, 13.

24 Archives d' Outre $\mathrm{Mer}(\mathrm{AOM}), \mathrm{G} \mathrm{GA}_{2} \mathrm{H}_{73}$ rapport sur l' insurrection de 1871 dans la province d'Alger.

25 Аом F80 1685-1686; P. Birnbaum, 'La France aux Français': Histoire des haines nationalistes (Paris: Le Seuil, 1993), 26o-263; P. Hebey, Alger 1898: La grande vague antijuive (Paris: NIL, 1996); G. Dermenjian, La crise anti-juive oranaise, 1895-1905: L'antisémitisme dans l'Algérie coloniale (Paris: L'Harmattan, 1986).

26 Аом F80 1748, Culte Israélite, ordinance of November 9, 1845 on the consistoire of Algeria; report of Béquet, Rapport au conseil de gouvernement, organisation du culte israélite en Algérie (Algiers, 1858).

27 Kamel Kateb, Européens, "indigènes" et juifs en Algérie, 1830-1962: Représentations et réalités des populations, Cahier 145 (Paris: Institut National D’Etudes Demographiques, 2001), 30-68. Florence Renucci, "Les juifs d' Algérie et la citoyenneté (1870-1902). Les enjeux d' un statut contesté," in Droit et justice en Afrique coloniale: Traditions, productions et réformes (Brussels: Publications de l'Université Saint-Louis de Bruxelles, 2013), 97-115. 
colonisation. ${ }^{28}$ This left the largest group of Arabs and Kabyles who under French law had a theoretical choice between their personal status, under Sharia law, or falling into line with the French civil code. While the latter was supposedly a-religious it was necessarily associated with French Christian and occupier rule. The path to naturalization was in fact more arduous and unpalatable than it seems by simply considering the legislative framework. Few chose to become French fully and in an increasingly racialised society, the holding of identity papers counted for little in daily life.

From this administrative logic it did not follow that conversion to Christianity would necessarily represent an act of naturalization. Yet it is testimony to Lavigerie's remarkable power of persuasion and political lobbying that he nevertheless managed to make that claim and to have the French state recognize the validity of his argument. By fiat rather than reasoned legal arguments, the Orphans of Algeria became French because of their sometimes coerced conversion. ${ }^{29}$ The Catholic church had campaigned for their citizenship—established through group naturalization - in a unique response to the Archbishop standing in the Republic. Of course north African Jews had been naturalized through the Crémieux decree of 1870 , the four townships of Senegal enjoyed specific citizenship rights since $1848,{ }^{30}$ but the naturalization of the orphans of Algeria represented a one-off initiative recognizing sui generis the ability of a religious society to adopt and thus make French an entire category of young Arabs.

The Algerian orphans thus became exceptional colonial subjects. They were Catholic because of their rescuing but they remained Arabs-in Algiers the Church made a concerted effort to ensure that their education would take place in Arabic as well as French-yet they were also French citizens. Lavigerie's broader political aims in setting up a path to French colonial citizenship was not assimilation but separate development under his paternal guidance. He had no desire to see "his" Arabs become ordinary Frenchmen- he particularly feared the bad influence of French working class mores. In his letter of March 30, 1889, his protégé Dr Vital pointed out: "It is true, as your eminence judiciously points out, that Algiers is unfortunately like all the large cities, a source of gangrene and by moving in I am unfortunately exposing myself to

28 Kateb, Européens, "Indigènes" et Juifs en Algérie. Also See Pierre-Jean Luizard, Le choc colonial et l'islam (Paris: La Découverte, 2006).

29 Evidence of coercion is limited but there are letters to the prefect in 1874-1875 denouncing forced conversions. See AGMAfr, B 768 letter from Abdelkader Ben Belkassoum, saint Donat, Constantine, June 11, 1875 .

30 See Mamadou Diouf, "The French Colonial Policy of Assimilation and the Civility of the Originaires of the Four Communes (Senegal): A Nineteenth Century Globalization Project," Development and Change 29, no. 4 (1998): 671-696. 
the contagion". ${ }^{31}$ In his colonial Utopia, Christian Arabs would remain rural and would lead the way for a renewal of Arab civilization - restoring North Africa to its antique past when St Augustine and St Cyprien roamed the earth. For Lavigerie the citizenship of his Algerian orphans followed directly from his own personal involvement but echoed his understanding of the Catholic Church in Algeria: a Church of martyrdom (with the cult of Geronimo) and pioneers (with the church of Augustine). While most as Patricia Lorcin and Alain Mahé have shown played up a range of cultural and racial divides between invaders (Arab) and native (Kabyles) along a familiar settler/pastoralist divide, Lavigerie engaged with the Arab world along religious lines. He had had some experience of Middle Eastern Arab identities and through his earlier work in favour of écoles d'orient, did not perceive Arab Christians to be anything else than a restoration - after the turmoil of Islam — of a civilization. ${ }^{32}$ There was thus a direct comparison to be made with the Maronite Christians of Lebanon who had themselves been the object of a colonial project of their own in Algeria as early as $1848 . .^{33}$

Christian Arabs would not be like the corrupt settlers - they would the new men of a new world - a colonial revival in a Christian Mare Nostrum. It is not insignificant that Lavigerie was particularly fond of antiquities and archaeology. His golden age was one in which North Africans were citizens of the Roman world. His project was transformative and engaged with the mythical revival of Latin colonialism which Bugeaud had promoted at the origins of the Algerian colony-in many ways his was an archaeology of this projectliterally exhuming the remains of Roman and Carthaginian North Africa-but it resembled some of the more naïve forms of colonial settlements. Of course, much like the Kabyle myth, this version of the past entailed an eschatological vision of the future which left the current situation wanting. Orphans grew up to be men and women without the heroic attributes of pioneers the prelate had dreamt for them.

\footnotetext{
31 AGMAfr, B9-78, letter of Dr Vital to Lavigerie, March 30, 1889.

32 Matthew Burrows, "'Mission civilisatrice': French Cultural Policy in the Middle East, 186o1914," The Historical Journal 29, 1 (1986): 109-135.

33 The project of mass colonization by Middle Eastern Christian Arabs was aborted due to the pressure from the Ottoman authorities and French desire to keep a protectorate mandate in Syria. Gérald Arboit, "De l' immigration des maronites en Algérie: Un aspect de la politique française à l'égard des communautés chrétiennes de Syrie entre 1848 et 1870," Revue française d'histoire d'outre-mer 87, no. 328-329 (2000): 231-239.
} 


\section{$2 \quad$ Algerian Orphans and the Development of a Colonial Project}

Compared with many people of a similar socio-economic level in the colony, we have much more complete information on the Algerian Orphans of Lavigerie. In particular we have access to a range of private files which give us a brief and incomplete notion of the continued relationship between orphans and church. Much of the correspondence refers to spiritual guidance but it is frequently interspaced with financial demands and narratives of failure to get a sense of the long-term obligations that had been incurred in rescuing children. The Church provided the orphans until the end of their education which varied from primary school and apprenticeship to medical education or seminaries. The children then received a settlement which was intended to set them up for whatever life their education had destined them for.

The choice of education was itself a product of a selection based on aptitude to learn in the specific environment of the orphanages in Algeria and France where the children were brought up. Most were sent to France and lived in a number of institutions pre-existing the crisis. ${ }^{34}$ By 1874 only 239 remained in schools as Children over the age of sixteen were taken off the registers and often served as paid domestic servants at the religious institutions were they had been raised. The religious education favoured the more malleable and younger orphans but even the less academically gifted were encouraged to take on a trade and trained accordingly. As they grew up the Church sought to provide spiritual guidance that would last a lifetime but it also accepted its material responsibilities. In this role the Church was initially supported by the Republican regime of the earlier phase of the Third Republic. ${ }^{35}$

In many ways the missionaries were engaging with the most literal form of paternalism: girls were given a dowry, boys a lump sum on coming of age and on marrying. Four of the most gifted children were trained at some speed for a medical degree with the intention to return them to missionary medical tasks in Algeria. Ultimately this failed to materialize and three out of four did not return. ${ }^{36}$ Yet all of them were provided with the means and credits assurances which enabled them to purchase a practice. While the Church attempted to steer the orphans away from urban centres where temptations might deviate

34 AGMAfr, Papiers Lavigerie B7 40-48, lists for 1872-1873.

35 AGMAfr Papiers Lavigerie B2 247.

36 AGMAfr Papiers Lavigerie, B9 69. One went to Jaffa and married a Miss Garnier; the second, Michel, married an officer's daughter named Irma Dumarché; another, called Mohammed, married in Gorron (Mayenne); only Vital settled in Algeria but in Algiers rather than the villages. 
them from the holier life they had been prepared for, many flocked to the urban centres to join in the new proletariat.

Whatever their fate the Church remained the main provider of patronage, credit and identity. When a servant wished to marry she had to resort to the Church. The Algerian clergy found itself in the position of providing evidence of civil identity in the shape of the Actes de notoriété. ${ }^{37}$ Some twenty years later, some like Berthe Louisant, a domestic servant in Grenoble-by then utterly naturalised and Christianized - sought to obtain a "document that could constitute somewhat my identity" in order for her to marry. ${ }^{38}$ This long term connection was sometimes maintained explicitly at the request of the orphans themselves, over the decades that followed 1868.

At the same time as when the administration attempted to resettle Alsatians and Lorrains fleeing German occupation, with limited results and means - the Catholic Church purchased land and rights. Acting like many large colonial businesses beforehand the Church acquired enough arable land for two village developments which were set in a commune mixte (a commune where the Arab population dominated demographically). Under the names of Ste Monique and St Cyprien (North African saints) the two little villages were set up as distinct entities but within close proximity from one another. St Cyprien was a saint name that had already been employed in Algeria when the first bishop of Algiers, Dupuch, founded his own small orphanage in 1839. ${ }^{39}$ The funding for the foundation of the villages combined French national assembly funding and Algerian funds. Between 1871 and 1877 the new Third Republic proved a very ambiguous regime and one in which the Catholic clergy could exercise a significant amount of influence. ${ }^{40}$ While Lavigerie manipulated local and national politicians into supporting his works, he also set up his organizations as societies - avoiding thus the debates on congregation politics. The villages were thus set up as belonging to a private society entrusted with the paternalist authority of the archbishop. The two villages were relatively plain in design (and in this sense did not echo the more grandiose Utopian urbanism of many paternalist enterprises of the 19th century) and only the large churches signalled them out as prestige ventures. As a colonial project, the plans were simple: a commercial society created in 1873 was endowed with land by Lavigerie. Each couple of colonists was attributed a house of 10 by 5 meters, 20

37 The registration of Algerian état civil was imposed by the law of February 23, 1882.

38 AGMAfr, Papiers Lavigerie, B7 110.

39 Abbé Monterat, Mémoire en faveur de Mgr Dupuch premier et ancien évêque d'Alger à l'appui de la manifestation du clergé d'Afrique (Algiers: n.p., 1852).

40 AGMAfr, Papiers Lavigerie, B2-247. 
hectares of land, 12 of which arable and 8 grazing, furniture, a plough, seeds and food for a year at a cost of 4,00o francs per household while the animals were offered as an interest free loan over ten years. ${ }^{41}$ Thanks to lobbying in the French parliament a second village was subsidized to the tune of 75,000 francs in 1875 .

Located close to the railways and in the midst of a plain overlooked by tribal territories, they could access colonial markets and the Algerian hinterland. As some of the orphans originating from these tribal groups they could maintain some family bonds while demonstrating, it was expected, the superiority of French farming and culture. Nuns would staff the dispensary and priest would provide primary education. Two churches were built. Each house would be simple but designed for the couples matched by the Catholic church. Ideally children would thus marry within the community and resist the lure of large cities. Reality failed to match the aspirations of course. Girls married for love or to escape the community, boys left to chance their fortune away from their villages. Incomers also mingled with the community and muddled somewhat the purity of the model villages. ${ }^{42}$ The Church turned into matrimonial agency set up couples (many of whom turned out to be quite dysfunctional), it also set up the Catholic schools and provided machinery and facilities. It also lent its name to the enterprise and gave credit worthiness to the new colonists. The Catholic dispensary was intended to be a window on the benefits of modernity - in this sense the Catholic church pre-empted many of the reforms of medical missionary work in the Catholic Church. In its location and aims the villages were meant to turn into beacons for conversion. It was hoped that tribesmen would spontaneously associate Catholic faith and modernity and, confusing correlation and causation, might convert. It became obvious to all that this model of conversion through development was illusory.

The history of the villages was marked by a series of tragic incidents, such as the murder of a priest in 1880 or an attack on its dispensary. ${ }^{43}$ Attacks on the medical structure and the general reluctance to attend most of its provisions reflected an active rejection of colonial medicine and not only the discerning

41 AGMAfr, B7-310 [1], Conseil supérieur de gouvernement, $3^{\mathrm{e}}$ commission, budget de 1876, subvention pour l'établissement des indigènes naturalisés français, élevés dans les orphelinats, 5 .

42 For instance Jeanne, daughter of Geronimo, married Augeix in 1892, a Frenchman from Royat-les-Bains working for the French railways, in spite of her father's desire that she should only marry a Christian Arab from Les Attafs. See AGMAfr Papiers Lavigerie, B9 448-454.

AGMAfr Papiers Lavigerie, B10 2. In February 188o. 
choice that was identified by Yvonne Turin. ${ }^{44}$ Beyond the difficulties of meeting the needs of its community and the cost of resourcing services for the Arab tribes, the villagers were always on the brink of economic survival themselves. At several times, the villagers had to call on the Church to bail them out. In 1892 their survival was in question when the crops failed across the entire North African colony.

For churchmen one of the main preoccupations was the risk of relapsing into Islam-either because of disillusionment with the harsh theocratic rule of village life which barred dissent and deviance or because meeting a mate within such a small community proved difficult. Being French nothing could stop the villagers from settling anywhere in France or Algeria and disappear. This anxiety kept the clergymen awake but it soon became a central aspect of the campaigns that were launched against the villages.

French Algerian politics in the 1870 os and 188 os took a decidedly anticlerical flavour with specific features studied by Saaïdia. ${ }^{45}$ The "opportunist" republicans ruled Algeria and their opponents, the Radicals, soon challenged the racial underpinning of this rule. Anticlericalism took a violent and visceral dimension. Algerians deputies targeted the villages as an anomaly, once sponsored by the public purse but also as one that challenged the social and religious norms of the colony. They denounced them as economic failures kept alive through unfair subsidies. They challenged the religious identity of the villagers and accused them of being Muslim in disguise-implicitly renouncing their French citizenship. Finally they lobbied that the villages should be drowned in larger entities where their identity would soon disappear. Despite their actual citizenship the administrators consistently attempted to challenge their religious identity or the relevance of religion to national identity. In every possible way that sought to place back the converts among the natives and deny them electoral rights. ${ }^{46}$ Journalists in the Republican press predicted that their fate would be an unviable one:

Everybody knows the repulsion Arabs have towards Jews, well it is even worse for Christian Arabs. So Mgr should not hide that should an insurrection occur, the first victims would certainly be his creatures. Let us hope

44 Yvonne Turin, Affrontements culturels dans l'Algére Coloniale: Écoles, Médecines, Religion, 1930-1880 (Paris: Maspero, 1971).

45 Oissila Saaïdia, 'L' anticléricalisme article d' exportation: Le cas de l' Algérie avant la première guerre mondiale," Vingtième Siècle: Revue d'histoire 87, no. 3 (2005): 101-112.

46 J. Tiquet, Une expérience de petite colonisation indigène en Algérie: Les colons arabes-chrétiens du Cardinal Lavigerie (Algiers: Maison Carrée, 1936), 93. 
for our own safety that the government of Algeria will prevent the setting of another centre composed exclusively of Christian arabs.

Reporting on the failure of the village, by then a few months old, the journalist then proceeded to report that their neighbours called them "the archbishop's slaves" 47 This reflected the fact that these villages were uniquely disruptive of the colonial order. After the group naturalization of 1874 the two villages became the only examples of universal suffrage returning entirely Arabic municipal councils in Algeria.

This disturbance endured and was regularly denounced as a subversion of colonial rule but also as a challenge to the rule of law and the defence of human rights. Somewhat disingenuously radicals intended to save the Christian Arabs from living their lives under the yoke of clericalism. In practice a constant campaign begun in 1874 sought to make the villages vanish as identifiable entities. By 1892 radicals got their way and the villages were absorbed into a larger village of colonization, created by decree in 1878 and renamed Wattignies in 1889 . Nevertheless the converts' very Catholic demography enabled them to grow to such an extent that it was them who took over the larger commune. ${ }^{48}$ Over two generations the growth of a Catholic and Arabic polity in the midst of a radical-socialist one challenged Algerian norms in more ways than one. Being Catholic was a first red flag to which, increasingly, being Arab was associated. Radicals accused the society of financial improprieties, of abuse of power and clerical interference in the life of the villagers and even the somewhat disingenuous championing of the civic rights of those who broke the theocratic rules. As a community these villages were set up very strictly and the society's churchmen led the parishes in strict paternalistic fashion. A drunk or a wife beater might get expelled as might a less religiously minded member of the community. Accused of keeping themselves to themselves, despite evidence of rapid interracial marriages, these villagers challenged their increasingly racialized notions of identity. The establishment of these communities in particular challenged the code de l'indigénat which codified in 1874 the regime of segregated inequality between colonists and ethnic groups of Algeria. ${ }^{49}$

Under this constant barrage of criticism, the Catholic Church started to doubt the validity of the claims that had been made for the villages. Unlike

47 AGMA fr, B7-302, Felix Devalier, Algérie, August 21, 1874.

48 АОМ 1 Y 110.

49 For an analysis of some of the medical grounding of racial theories in Algeria see Patricia M.E. Lorcin, "Imperialism, Colonial Identity, and Race in Algeria, 1830-1870: The Role of the French Medical Corps," Isis 9o, no. 4 (1999): 653-679; Olivier Le Cour Grandmaison, De l'indigénat. Anatomie d'un "monstre" juridique: Le droit colonial en Algérie et dans l'empire français (Paris: Zones/La Découverte, 2010), chapter 2. 
model factories or farms, the villages had not retained their experimental purity and, beyond its main critiques, it did not attract as much positive or supportive attention as had been anticipated. As père Tiquet writing in the $1930 \mathrm{O}$ chronicled the life of the villages, he reported on the stories of village tensions and noted that there were not many significant differences between the Arab villagers and other colonists of the commune when it came to their deportment and morality.

After a hiatus of some twenty years the villages came back to the attention of the metropolitan state in 1902. At the peak of the debates on the separation of Church and State, the fiercely anticlerical Combes' ministry responded to local pressure to investigate how a small village could be controlled by clerically minded Arabs. ${ }^{50}$ The response investigated how gerrymandering might enable radicals to dominate but only to admit that it had already done so in the past to no effect:

It is not within the reach of the administration to put down this clerical centre since we are facing citizens exercising their rights legally and according to our legislation ... as to modifying the sections in order to favour the Frenchmen of European origins, our administration has done what it could at this stage. The political importance of this situation is minimal. The case of a village of Arabs educated by Catholic priests is unique in Algeria and there is no reason to believe it will occur again. ${ }^{51}$

At the same time Radicals promoted as a victim of clerical violence a local drunkard Philippe Djelloul, who had been expelled from St Cyprien. Under public opinion pressure and the sustained campaigning of the left wing press, the oeuvre des orphelinats disposed of its assets and ceased trading in 1904. Setting the villages free the society gave to Christian Arabs full ownership of their villages while removing itself from governing them. Despite this removal, villagers remained under scrutiny. For the leadership of the villages, there could be no peace in the "Clochemerle" world they inhabited. Their local politician Frachebois was at once a dangerous radical for the White Fathers and a rabid clericalist for the Radicals who hated what he stood for. Frachebois was under close scrutiny from the French prefecture in particular for his supposed favouring of native and clerical interests over newly settled Europeans. ${ }^{52}$ Arab converts could not satisfy either Christian idealism or Radical anticlericalism.

\footnotetext{
5 о $\quad$ AOM F/8o/1693.

51 АОм F/8०/1693, rapport du préfet, 20/12/1902.

52 AGMAfr B9 435 each supporter of Frachebois was accused of betrayal by the White Fathers.
} 
This inability to belong to the colonial order is one witnessed in the files of individuals working in the colony. Some acting as translators or teachers, such as Célestin Salem, intituteur at the Commune mixte de Fort National would come under similarly untenable pressures. The Commune accused Salem of being clerically minded in being unwilling to teach his Muslim pupils on Sunday. ${ }^{53}$ Despite his heroic resistance to the authorities on a point of principle, Churchmen found fault in his writings and in his school which seemed to them too secular. ${ }^{54}$ When he applied for his children to received private Catholic education, the clergy refused on the ground that he was still employed in a secular school system. Acutely aware of the fact that the White Fathers had now prioritized sub-Saharan Africa, he protested that racial discrimination was now in place in the missionary world and that "African negroes" rather than white children were now catered for. This assimilation to whiteness when, some might argue the colonial world emphasized the non-whiteness of Algerians, signifies the difficulty of standing on the threshold of a racialized colonial society. ${ }^{55} \mathrm{In}$ his own setting, Salem prided himself on baptizing his own entire family and 14 orphans in articulo mortis.

In civil law Christian Arabs faced the complexities of straddling two separate legal systems and of having different rules on most things than their own closest relatives. Sharia law might apply to part of their family as might the laws regulating property while they could no longer call on this specific jurisdiction. The French legal regime in Algeria created endless zones of friction and community boundaries.

Their hybridity had been the purpose of setting them up as alternative colonial villages but this Creole identity relied on being able to maintain some kind of equilibrium between two cultural and economic contexts. Like the more autonomous orphans around France and Algeria, they had been forcibly alienated from mainstream Algerian culture. They spoke and wrote Arabic but they had learnt it through readings of the New Testament rather than Muslim sacred texts. As a community there were too few of them to preserve the endogamy that alone would have preserved the validity of the experiment. Ironically Catholic policies ended up seeking a kind of racial purity they berated in their political adversaries. Yet the reality soon caught up as Arab widows married Europeans. Even within the first generation mixed marriages outnumbered

53 On instituteurs see Fanny Colonna, Instituteurs Algériens, 1883-1939 (Paris: Sciences Pos, 1975).

54 AGMAfr, PL, B9 237-243.

55 AGMAfr, PL, B9 248, 16.01.1891. 
endogamous ones. ${ }^{56}$ While their detractors reified their Arab nature it seems that the village dwellers became examples of colonial assimilation into the Mediterranean melting pot of European settlers. Furthermore the villages were drained by the appeal of large multicultural colonial cities. St Cyprien declined from 38 o inhabitants in 1909 to 16 o in 1921, following thus the general pattern of Algerian rural exodus.

The missionary developmental project survived its initial aims but failed its grander aspirations - in contrast the villages set up around missions in subSaharan Africa seemed to have been much more popular and successful, what were the causes of this mediocre success? The first point is clearly the lack of clarity of these settlements in relation to colonial ones. Set up as businesses in order to resist the political pressures on religious congregations, the villages were economically dependent for much of their initial existence. They were not colonial projects aligned with the settlers' own free trading agenda benefiting as they did from endowments and subsidies. Economically dependent they also challenged the political status quo around the personal status of Arab subjects. ${ }^{57}$ They were full of citizens whose citizenship and French identity it was claimed rested on their religion and their Arab origins - in contrast to the naturalization of Europeans of various origins whose assimilation in the French polity was based neither on nativism nor culture or religion but rather on some vague racial assimilation: they had become French because they were not Arabs. Though a small and vulnerable group, the Arab converts presented a robust and disturbing challenge to the settlers-while they also challenged the fallacy of the personal status of Muslim subjects. In a society increasingly resting on the proletarianization of the Arab people and their political marginalization, they presented a challenge that could not be ignored even if it was a kind of evolutionary political and governmental dead end. Paradoxically they also challenged — as was intended - traditional society and it is this challenge to society that remains today for the handful of Christian converts still living in Algeria. ${ }^{58}$

$5^{6} \quad$ Tiquet, Une Expérience, 126.

57 On the complexities see "Des Effets Juridiques du Changement de Religion en Algerie," J. Dr. Int'l Prive \& Juris. Comparée 375 (1908).

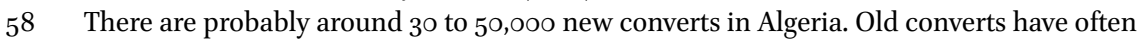
left Algeria with the French and are now almost invisible. Karima Dirèche, "Évangélisation en Algérie: débats sur la liberté de culte," L'Année du Maghreb 5 (2009): 275-284, available via http://journals.openedition.org/anneemaghreb/596; DoI: 10.40oo/anneema ghreb.596. 
The material conditions of the mission - to borrow from Jean Pirotte's concept-became the more preoccupying aspect of its existence.$^{59}$ The theocratic model failed in a secularist environment, it was economically mediocre and socially ordinary. As an ideal of developmentalism it failed to live up to the high aspirations its promoters had. Algeria closed up again to proselytizing not because of the military concerns that had been so restrictive before 1870 but because religious conversion threatened the established order of a profoundly segregated society. The hybridity that convert citizens represented challenged all forms of social and political structuring in place or in the making in Algeria. Like many of Lavigerie's grand schemes the mundane details of the programme did not live up to the prospectus claims. The humanitarian funding at the onset had been a one off which became difficult to sustain over the long term - the conversion of the Arabs remained an unfulfilled aspiration and the archaeology of the church of St Augustine only populated the museums.

\section{Bibliography}

Archives des Missionnaires d'Afrique (AGMAfr). Papiers Lavigerie.

Archives Nationale d' Outre Mer. Fonds des départements d' Alger, Constantine et Oran. La misère d'Algérie.

Arboit, Gérald. "De l'immigration des maronites en Algérie: Un aspect de la politique française à l'égard des communautés chrétiennes de Syrie entre 1848 et 1870." Revue française d'histoire d'outre-mer 87, no. 328-329 (2000): 231-239.

Aldrich, Robert. The French Presence in the South Pacific, 1842-1940. London: Macmillan, 1990.

Barthès, Henri. Monseigneur de las Cases, évêque de Constantine. Montpellier: Presses Universitaires de Paul Valéry, 1980.

Barnett, Michael ed. Paternalism Beyond Borders. Cambridge: Cambridge University Press, 2017.

Bellarmin-Vincent Burzet, Abbé. Histoire des désastres de l'Algérie, 1866-1867-1868: Sauterelles, tremblement de terre, choléra, famine. Algiers: Garaudel, 1869.

Bennoune, Mahfoud. "Origins of the Algerian Proletariat." Middle East Report 94 (1981). Benoist, Joseph-Roger de. Église et Pouvoir Colonial au Soudan Français. Paris: Karthala, 1987.

Birnbaum, Pierre. 'La France aux Français': Histoire des haines nationalistes. Paris: Le Seuil, 1993 .

59 Jean Pirotte ed., Les Conditions Matérielles de la Mission (Paris: Karthala, 2004). 
Burrows, Matthew. “'Mission civilisatrice': French Cultural Policy in the Middle East, 186o-1914." The Historical Journal 29, 1 (1986): 109-135.

Ceillier, Jean-Claude. Histoire des missionnaires d'Afrique (Pères Blancs), de la fondation par Mgr Lavigerie à la mort du fondateur (1868-1892). Paris: Karthala, 2008.

Colonna, Fanny. Instituteurs Algériens, 1883-1939. Paris: Sciences Pos, 1975.

Curtis, Sarah E. Civilizing Habits: Women Missionaries and the Revival of French Empire. Oxford: Oxford University Press, 2010.

Daughton, James-Patrick. An Empire Divided: Religion, Republicanism and the Making of French Colonialism, 1880-1914. Oxford: Oxford University Press, 2006.

Daughton, James-Patrick and Owen White. In God's Empire: French Missionaries and the Modern World. Oxford: Oxford University Press, 2011.

Denéchère, Yves. "Histoires croisées des orphelins et de l' adoption." In Invisibles orphelins, edited by Magali Molinié. Paris: Autrement, 2011.

Dermenjian, G. La crise anti-juive oranaise, 1895-1905: L'antisémitisme dans l'Algérie colonial. Paris: L'Harmattan, 1986.

“Des Effets Juridiques du Changement de Religion en Algerie." J. Dr. Int'l Prive \& Juris. Comparée 375 (1908): 375-395, 989-1001.

Diouf, Mamadou. "The French Colonial Policy of Assimilation and the Civility of the Originaires of the Four Communes (Senegal): A Nineteenth Century Globalization Project." Development and Change 29, no. 4 (1998): 671-696.

Dirèche, Karima. Chrétiens de Kabylie (1873-1954): Une action missionnaire dans l'Algérie coloniale. Saint Denis: Bouchène, 2004.

Dirèche, Karima. "Les écoles catholiques dans la Kabylie du XıX siècle." Cahiers de la Méditerranée 75 (2007): 17-27, available via http://journals.openedition.org/cdlm/ 3333.

Dirèche, Karima. "Évangélisation en Algérie: débats sur la liberté de culte." L'Année du Maghreb 5 (2009):275-284, available via http://journals.openedition.org/anneemag hreb/596; Dor: 10.400o/anneemaghreb.596.

Émerit, Marcel. “Le problème de la conversion des musulmans d' Algérie sous le Second Empire: Le conflit entre Mac-Mahon et Lavigerie." Revue Historique vol. 223, no. 1 (1960): 63-84.

Frémeaux, Jacques. Les bureaux arabes dans l'Algérie de la conquête. Paris: Denoël, 1993.

Le Cour Grandmaison, Olivier. De l'indigénat. Anatomie d'un "monstre" juridique: Le droit colonial en Algérie et dans l'empire français. Paris: Zones, 2010.

Hannoum, Abdelmajid. "Colonialism and Knowledge in Algeria: The Archives of the Arab bureau." History and Anthropology 12, no. 4 (2001): 345-379.

Hanoteau, Adolphe, and Aristide Letourneux. La Kabylie et les coutumes Kabyles. Paris: Imprimerie Nationale, $1872-1873$.

Hebey, P. Alger 1898: La grande vague antijuive. Paris: NIL, 1996.

Hugonnet, Léon. La Crise algérienne et la démocratie. Paris: Chevalier, 1868. 
Julien, Charles André. Histoire de l'Algérie Contemporaine, vol. 1. Paris: Presses Universitaires de France, 1986.

Kateb, Kamel. Européens, “indigènes” etjuifs en Algérie, 1830-1962, représentations et réalités des populations. Paris: Presses Universitaires de France, 2001.

Lester, Alan, and Fae Dussart. Colonization and the Origins of Humanitarian Governance: Protecting Aborigines across the Nineteenth-Century British Empire. Cambridge: Cambridge University Press, 2014.

Lorcin, Patricia M.E. Kabyles, arabes, français: Identités colonials. Limoges: Presses Universitaires de Limoges, 2005 .

Lorcin, Patricia M.E. "Imperialism, Colonial Identity, and Race in Algeria, 1830-1870: The Role of the French Medical Corps." Isis 9o, no. 4 (1999): 653-679.

Luizard, Pierre-Jean. Le choc colonial et l'islam. Paris: La Découverte, 2006.

Mahé, Alain. Histoire de la Grande Kabylie, anthropologie historique du lien social dans les communautés villageoises. Saint Denis: Bouchène, 2001.

Montclos, Xavier de. Lavigerie le Saint-Siège et l'Église: De l'avènement de Pie IX à l'avènement de Léon XIII, 1846-1878. Paris: de Boccard, 1965.

Monterat, Abbé. Mémoire en faveur de Mgr Dupuch premier et ancien évêque d'Alger à l'appui de la manifestation du clergé d'Afrique. Algiers: n.p., $185^{2}$.

Pirotte, Jean, ed. Les Conditions Matérielles de la Mission. Paris: Karthala, 2004.

Renault, François. Le Cardinal Lavigerie. Paris: Fayard, 1992.

Renucci, Florence. "Les Juifs d'Algérie et la citoyenneté (1870-1902): Les enjeux d'un statut contesté." In Droit et justice en Afrique coloniale: Traditions, productions et réformes, 97-115. Brussels: Publications de l'Université Saint-Louis de Bruxelles, 2013.

Rey-Goldzeiguer, Annie. Le Royaume arabe, la politique algérienne de Napoléon III. Algiers: Société Nationale d'Édition et de Diffusion, 1977.

Robin, Colonel. L'Insurrection de la Grande Kabylie en 1871. Paris: Charles Lavauzelle, 1900.

Saaïdia, Oissila. Algérie coloniale. Musulmans et chrétiens: Le contrôle de l'Etat (18301914). Paris: CNRS, 2015.

Saaïdia, Oissila. "L'anticléricalisme article d'exportation: Le cas de l'Algérie avant la première guerre mondiale." Vingtième Siècle: Revue d'histoire 87, no. 3 (2005): 101112.

Sari, Djilali. Le désastre démographique. Algiers: Société Nouvelle d'Édition et de Diffusion, 1982.

Spillmann, Georges. Napoléon III et le royaume arabe d'Algérie, Travaux et mémoires de l'Académie des sciences d' outre-mer, nouvelle série 3. Paris: Académie des Sciences d' Outre-mer, 1975.

Taithe, Bertrand. "Missionary Militarism? The Armed Brothers of the Sahara and Leopold Joubert in the Congo." In God's Empire: French Missionaries and the Modern 
World, edited by James-Patrick Daughton and Owen White, 129-150. Oxford: Oxford University Press, 2011.

Taithe, Bertrand. "Algerian Orphans and Colonial Christianity in Algeria 1866-1939." French History 20, no. 3 (2006): 240-259.

Tiquet, J. Une expérience de petite colonisation indigène en Algérie: Les colons arabeschrétiens du Cardinal Lavigerie. Algiers: Maison Carrée, 1936.

Turin, Yvonne. Affrontements culturels dans l'Algére Coloniale: Écoles, Médecines, Religion, 1930-1880. Paris: Maspero, 1971.

Urvoy, Dominique. "Les conversions au catholicisme en Algérie." Outre-Terre 4, no. 45 (2015): 249-255.

Zom, Jean-François. Le Grand Siècle d'une mission protestante: La mission de Paris de 1822 à 1914. 2nd ed. Paris: Karthala, 2012. 


\title{
Missionary Work, Secularization, and Donor Dependency: Rockefeller-Near East Colleges Cooperation after World War I (1920-1939)
}

\author{
Philippe Bourmaud
}

Relations with foreign donors often put humanitarian NGOs and academic institutions in a catch-22. On the one hand, competition for funding allows major donors to impose political agendas upon them. On the other hand, with the exception of boogeymen such as George Soros, aid-receiving organizations, rather than donors, are generally blamed in local political discourse for the enforcement of external agendas. In contemporary Egypt and Israel, this suspicion has served as a pretext to take on foreign-funded NGo s. ${ }^{1}$ Agenda dependency induces to favour professionalism and capacity of action over political and axiological commitment, ${ }^{2}$ and is therefore seen as a seemingly non-political vehicle for hidden agendas.

Faith-based private voluntary organizations have a history from that perspective. In the late Ottoman Empire and Republican Turkey, missionary organizations have been denounced as the instruments of imperialistic states, the vehicles of cultural domination, and the perpetrators of a spiritual blackmail to attract missionized population under external influence. What is true of the Middle East would also be relevant in other former colonial or non-Western countries such as India and China. Yet in the last few decades, faith-based NG o s have banked on their religious nature to bolster their credibility: religious values have been publicized as a guarantee of reliability and of autonomy vis-à-vis major donors. ${ }^{3}$

1 "Egypt: New Law Will Crush Civil Society," Human Rights Watch, June 2, 2017, accessed April 27, 2018, https://www.hrw.org/news/2017/o6/o2/egypt-new-law-will-crush-civil-socie ty; Peter Beaumont, "Israel Passes Law to Force NGO s to Reveal Foreign Funding," The Guardian, July 12, 2016, accessed on April 27, 2018, https://www.theguardian.com/world/2016/jul/ 12/israel-passes-law-to-force-ngos-to-reveal-foreign-funding.

2 For a Palestinian example: Caroline Abu-Sada, oNG Palestiniennes et construction étatique: L'expérience de Palestinian Agricultural Relief Committees (PARC) dans les Territoires occupés palestiniens 1983-2005 (Beirut: Presses de l' IF PO, 2013).

3 Marie-Juul Petersen, For Humanity or for the Umma? Aid and Islam in Transnational Muslim NGO S (Oxford: Oxford University Press, 2016). 
Does the religious nature of the organizations make them more susceptible to dependency on external donors, or more autonomous, than secular ones? And why do they seem to show varying receptibility to the influence of external donors? Part of the answer lies in context and the ways in which donor dependency works: the patterns of donor dependency are polymorphous and multidirectional, depending on the length of the relation, and on the donors' capacity of control on the ground. ${ }^{4}$ Differences are usually explained by varying effectiveness in following up on the procedures of project evaluation, ${ }^{5}$ rather than on account of intrinsic features of the organizations. But faithbased private voluntary organizations working abroad are held to a mission statement, in the strong, literal sense. Their receptivity to external influence lies less in their stated goal than in what they do, which is not limited to proselytizing. Over the 19th and early 2oth centuries, the functions assumed by missionaries expanded into assistance to women and families, education, medicine, higher education, and relief work in the midst of humanitarian crises. The trend imposed a parallel increase in financial resources.

How to analyze the way the religious factor plays without assumptions of instrumentality at the service of external agents and institutions, or of specificity of religious callings? One way to compare secular and missionary receptivity to the influence of donors is to consider missionary institutions that change their general perspective and become secularized.

The cooperation between American Protestant missionary colleges in the Middle East and the Rockefeller Foundation ( $\mathrm{RF}$ ) is a test case here. In the Middle East, the post-World War I period saw the Near East Colleges Association (NECA), a group of American Protestant academic institutions, apply for RF funds. It included institutions founded by the (Presbyterian) American Board of Commissioners for Foreign Missions (ABCFM), such as Robert College and the American College for Girls (ACG, also known as Constantinople Woman's College) in Istanbul and the Syrian Protestant College (SPC) in Beirut. ${ }^{6} \mathrm{RF}$ money implied the adoption of secular methods of sanitary and social service. The institutions forming the Near East College Association were already moving towards secular methods and outwardly secular goals, and it is

4 Jeffrey A. Lefebvre, "Donor Dependency and American Arms Transfers to the Horn of Africa: the F-5 Legacy," The Journal of Modern African Studies 25, no. 3 (September 1987): 465-488.

5 Charles H. Kennedy, Ijaz Hussein, and S. Akbar Zaidi, "Reconsidering the Relationship between the State, Donors, and NGo s in Bangladesh [with Comments]," The Pakistan Development Review 38, no. 4 (Winter 1999): 489-510.

6 This research benefited from a travel grant of the Rockefeller Foundation to do research at the Rockefeller Archives Center (Tarrytown, NY). 
worth asking to what extent $\mathrm{RF}$ influence accelerated the evolution. Of significance here is the fact that the RF-NECA cooperation developed as the foundation and the colleges were all involved in humanitarian relief work delivered under the umbrella of the American Committee for Armenian and Syrian Relief established in 1915, later to be renamed the Near East Relief (NER) after World War I, and finally the Near East Foundation (NEF) in 1930. What role did the colleges' own needs, the strategic plans of the Rockefeller Foundation and the circumstances of their common involvement in humanitarian action play respectively in shaping RF-NECA cooperation and the values of the colleges?

Cooperation between an American philanthropy such as the Rockefeller Foundation and American missionaries raises a more general question of strategy. Specialists of missionary history have criticized the idea that Western missions were the instruments of national strategies and more generally warned against strategic readings of missionary work, which often produced "unexpected" effects. ${ }^{7}$ Yet historians of international relations have recently put forward analyses of the operations of American private voluntary organizations abroad based on an orchestrated effort inspired by nationalism. David Ekbladh describes a convergence of public and private actors in the pursuit of global modernization starting in the 1910s, which "was not always humanitarian, but strategic" 8 and paved the way for government-led cooperation programs.

Understanding the convergence of views materialized by the cooperation between the Rockefeller Foundation and the Near East colleges requires more than invoking a shared nationalism with strong Protestant undertones, but less than positing missionaries as tools of modernization designed to serve foreign policy, in a predefined global modernization plan. The Rockefeller Foundation and the colleges had their own, largely financial concerns, and it is fair to ask if the convergence of their views in the 1920 s resulted from shared secular and nationalistic views on cooperation, wholesale strategic planning, or more opportunistic exertions of influence enabled by donor dependency.

A related question is that of instrumentality. Did the Rockefeller Foundation manage to instrumentalize the Near East colleges in the pursuit of a global strategy - and if so, whose strategy? Historiography has dwelled on the massive RF projects conducted in China in the first half of the 2oth century, to

7 Heather J. Sharkey, "Introduction: The Unexpected Consequences of Christian Missionary Encounters," in Cultural Conversions: Unexpected Consequences of Christian Missionary Encounters in the Middle East, Africa, and South Asia, ed. Heather J. Sharkey (Syracuse, NY: Syracuse University Press, 2013), 1-26.

8 David Ekbladh, The Great American Mission: Modernization and the Construction of an American World Order (Princeton: Princeton University Press, 2010), 2. 
support the notion of global modernization developing under strategic planning. But looking at the Middle East may help relativize the notion, even though NECA officials paid close attention to the Chinese case. Cooperation, growing out of a situation of humanitarian emergency, left the Near East colleges in an inferior position. Yet it did not entail a takeover by the foundation. This owed to the latter's goals of local capacity-building rather than building an academic empire, but also to missionary techniques of crowdfunding. Donor pressure did not shape the colleges like clay, but tried to set goals and standards without entangling itself in a long-term pattern of patron-client relationship. The influence of the foundation did, however, contribute to the academic differentiation between the colleges and the rationalization of their financial organization, leading to the incorporation of the Near East Colleges Association in 1927.

\section{Missionary Colleges into Humanitarian Institutions}

\subsection{Contested Missionary Methods}

RF-NECA cooperation depended on an agreement on common goals, which was not a forgone conclusion. Protestant foreign missions, starting from scratch in the Middle East, Africa, South Asia, and China in the early 19th century, generally took conversion to be the first and utmost humanitarian goal of all their diverse endeavours: religious propaganda, but also auxiliary work such as medicine, visits to women, teaching, engineering, or professional training. ${ }^{9}$ Auxiliary work often had a tag on it, namely that it should explicitly serve the primary goal of proselytizing, possibly at the expense of its own ends.

Missionary methods matched this aim, at the expense of other this-worldly goals. Missionaries aimed at making contacts far and wide on the missionary field and affording as much religious discussion time as possible. Yet this often clashed with the deontology of auxiliary work, such as medical mission, "women's work", relief, or professional training. ${ }^{10}$ The missionary dimension of auxiliary work was often under scrutiny. This may be overlooked because, on account of the difficulty to broach religious discussion with non-Christians

9 Terril E. Lautz, "The SVM and Transformation of the Protestant Mission to China," in China's Christian Colleges: Cross-Cultural Connections, 1900-1950, eds. Daniel Bays and Ellen Widmer (Stanford: Stanford University Press, 2009), 12.

10 John S. Baick, "Cracks in the Foundation: Frederick T. Gates, the Rockefeller Foundation, and the China Medical Board," The Journal of the Gilded Age and Progressive Era 3, no. 1 (2004): $72-73$. 
in certain fields, China and the Middle East especially, medicine and education became prominent dimensions of Christian missions. Yet from a missiological point of view, neither of them was a consensual method. For most of the 19th century and even beyond, there were differences on how to use them and what for, and on whether they should be regarded as a form of mission in themselves. ${ }^{11}$

These debates and repeated caveats urging missionaries to maintain the priority of the mission's religious goals shaped the methods and atmosphere of the missions. Medical missions were warned against developing central hospitals. It was feared medical service should, to quote a medical missionary journal of the Anglican Church Missionary Society (CMs), "demand too exclusively the energies and attention of those who are in charge. The Medical Missionaries, if they are to do effective pioneer work, must not be too much tied to the centre". ${ }^{12}$ Much importance was given to bedside talk, as well as to itinerations away from the urban centres as a way to attract patients liable to be hospitalized, in order to find occasion for discussion on religion. ${ }^{13}$ Missions tended to be labour-intensive and despite the numerical preponderance of indigenous missionaries, ${ }^{14}$ this pushed payroll expenditure up.

High labour costs and the dissemination of missionaries made it necessary for missionary societies, which were not self-supporting, to prioritize rigorously their expenditure. What would in time come to be regarded as the humanitarian dimension of missionary work was contested from within as a financial distraction from strictly religious endeavours. Medical mission was looked down on as "hardly more than bribes to draw people to hear the Gospel, mere secular adjuncts to missionary work". ${ }^{15}$ True enough, medical and educational work was accepted, if only because competition with Catholic missions created an incentive to occupy the field. ${ }^{16}$ Still, missionary supervising bodies tended

11 Ryan Dunch, "Science, Religion, and the Classics in Christian Higher Education to 1920," in China's Christian Colleges: Cross-Cultural Connections, 1900-1950, eds. Daniel Bays and Ellen Widmer (Stanford: Stanford University Press, 2009), 59-63; Samir Boulos, European Evangelicals in Egypt (1900-1956): Cultural Entanglements and Missionary Spaces, Studies in Christian Mission 48 (Leiden: Brill, 2016), 82-94.

12 A. Lankester, "Some Observations on General Mission Policy," Mercy and Truth vol. 1, no. 10 (October 1897): 223 .

13 Lankester, "Some observations," 220; Albert Cook, "Medical Itineration," Mercy and Truth vol. 5, no. 66 (June 1902): 174-179.

14 Sharkey, "Introduction," 11.

15 H. Lankester, "Medical Missions in Theory," Mercy and Truth vol. 3, no. 38 (February 19oo): 38.

16 See, among others: Julia Hauser, German Religious Women in Late Ottoman Beirut: Competing Missions, Studies in Christian Missions 45 (Leiden: Brill, 2015); Nazan Maksudyan, 
to object. Higher education was an even more fraught issue: it was intended to serve missions by providing trained indigenous staff, but it appealed to students far beyond potential missionaries, among Muslims in particular. Was it worth the cost?

\subsection{An Expanding Branch of Auxiliary Work: Missionary Colleges and Social Service and Relief as New Goals}

Missionary colleges multiplied before World War I. In the Ottoman Empire, they were uniformly Presbyterian. The ABCFM had started founding missionary colleges in the Ottoman Empire in the 1860s, initially with a view to training future missionaries. In Istanbul, Robert College was founded in $1863,{ }^{17}$ followed by the American College for Girls, established in 1871 and reorganized in $1890 .{ }^{18}$

Yet much like medical missions and schools, Protestant missionary colleges were contested as a diversion from narrowly missionary, i.e. propagandistic functions. It had been argued, in their early years, that to train indigenous missionaries, they should welcome converts or children of converts only. ${ }^{19}$

By the 189os, stated goals were changing. Major Protestant missionary organizations had started putting a stress on efficiency in auxiliary work. Investments in medical missions grew accordingly. The ends of the various forms of auxiliary work came, grudgingly, to be considered in their own rights.

This transformation went against the practice of missionary organizations, that had grown global through bureaucratic control and the assimilation of cost/benefit analysis. What Delphine Gardey has called "a revolution of paper"-keeping and possibly typing records, using charts, posting financial data into a bureaucratic apparatus-intensified long-distance operations. ${ }^{20}$ The Near East colleges could be supervised by a board of New Yorker patrician

Orphans and Destitute Children in the Late Ottoman Empire (Syracuse, NY: Syracuse University Press, 2014); Lorella Ventura, Hegel in the Arab World: Modernity, Colonialism, and Freedom (London: Palgrave MacMillan, 2018).

17 Aslı Gür, "Robert College: Laboratory for Religion, Shrine for Science-Transculturation of Evangelical College Model in Constantinople," in American-Turkish Encounters: Politics and Culture (1830-1989), eds. Nur Bilge Criss, Selçuk Esenbel, Tony Greenwood, and Louis Mazzari (Newcastle upon Tyne: Cambridge Scholars Publishing, 2011), 48-6o.

18 Mary Mills Patrick, A Bosphorus Adventure: Istanbul (Constantinople) Woman's College, 1871-1924 (Stanford: Stanford University Press, 1934).

19 Loren W. Crabtree, "Andrew P. Happer and Presbyterian Missions in China, 1844-1891," Journal of Presbyterian History 62, no. 1 (Spring 1984): 31; Paul W. Harris, "Cultural Imperialism and American Protestant Missionaries: Collaboration and Dependency in MidNineteenth-Century China," Pacific Historical Review 6o, no. 3 (August 1991): 334.

20 Delphine Gardey, Ecrire, Calculer, classer: Comment une révolution de papier a transformé les sociétés contemporaines, 1800-1940 (Paris: La Découverte, 2008). 
trustees after their registration in the state of New York. But on account of the distance, supervision of the missions rested on quantifiable criteria of efficiency. The institutions now aimed at more secular goals: rationalization through centralization, promoting science-based policy making, and training a socially aware leadership. ${ }^{21}$

This was partly due to the trends in the recruitment of missionaries abroad. Starting in the 189os, American missionary organizations, under the influence of progressive nationalism, gave increased importance to social service work.

War circumstances shaped the mutation of missionary colleges into relief organizations. With the 1915-1916 famine, the SPC collaborated with the American Red Cross to transfer food and money to the Syrian population, set up soup kitchens in Beirut and dispensaries. ${ }^{22}$ After the end of the war, the NER brought together missionary organizations, American missionary colleges, and philanthropies headed by the Rockefeller Foundation. ${ }^{23}$ Missions and Protestant colleges played an active role in the NER. ${ }^{24}$ The NER, after 1930 the NEF, would continue working with RF money and in cooperation with the AUB all through the Interwar years before expanding its geographical scope, focusing on rural development.

The second consequence of the war, for the colleges, was a cash crunch. Relief operations were a drain on their budget, entailing sudden jumps in contingency expenditure. Impoverished families were hard put to pay the tuition fees. ${ }^{25}$ The devaluation of the us dollar in 1917 reduced the purchasing power of the colleges' income, as donations were labelled in us currency. ${ }^{26}$ Following World War I, American missionary colleges were pressed to find ready money. RF-missionary cooperation was already well under way in China, but it took the emergency of the post-war years for it to take shape in the Middle East.

\footnotetext{
21 Lautz, "The svM," 4.

22 Watenpaugh, Bread from Stones, 47-54.

23 George E. Vincent, The Rockefeller Foundation: A Review for 1919; Public Health and Medical Education in Many Lands (New York: The Rockefeller Foundation, 1920), 36.

24 Near East Relief, Report to Congress for 1925 (New York: Near East Relief-National Headquarters, 1926), 11-12.

25 Dong Wang, Managing God's Higher Learning: U.S.-China Cultural Encounters and Canton Christian College (Lingnan University) 1888-1952 (Lanham, MD: Lexington Books, 2007), 96; Robert College Records (New York: Columbia University Libraries, Rare Book and Manuscript Library), available at Boğaziçi Üniversitesi Archives, Istanbul (hereafter CUL/ RBML, RC), American College for Girls Records (hereafter ACG), Box 20, file 18: President's Report with Statistics 1920-1921, 16-17.

26 Wang, Managing God's Higher Learning, 96.
} 


\section{Near East Colleges Association: Secularization and Institutional Competition}

2.1

\section{A Gradual Trajectory out of Debt}

In the Middle East, it was post-war emergency and heavy debts, not a strategic plan, that prompted the Near East colleges to take an interest in the Rockefeller Foundation. The latter had already been involved in the foundation, in 1915, of the American Committee for Armenian and Syrian Relief, the forerunner of the NER. ${ }^{27}$ In 1920, a promise was made by the Rockefeller Foundation to examine the circumstances under which a program of direct help to the Near East Colleges Association could happen. ${ }^{28}$ Yet over the next four years, the adoption of a cooperation plan was postponed due to hesitations from the foundation.

Cooperation between the Rockefeller Foundation and the Near East Colleges Association was instituted in three steps. Big donations were campaigned for in order to face economic hardships when the association launched an emergency plan in 1922, as Beirut and Istanbul were facing masses of incoming refugees. Formal cooperation took the form of a contingency plan to solve debt problems and train professional researchers by 1924. An expansion plan to achieve the transformation of the colleges into research institutions after 1927. I will dwell mostly on the former two plans here.

\subsection{Ecologies of Project Planning}

The Near East colleges were not completely a new matter for the Rockefeller philanthropy, but the post-war conditions led to a vast increase of the aid. John D. Rockefeller had long funded the SPC at the tune of $\$ 5$,000 a year, yet more ambitious contributions were initiated by the fund dedicated to the memory of his wife, the Laura Spelman Rockefeller Memorial Fund (LSRM). When the Near East Colleges Association launched a first donation drive to face the immediate needs of the colleges and the increased expenses due to the relief operations they participated in, the LSRM gave the largest contribution, a third of the grand total of $\$ 1,102,000$ that were collected. ${ }^{29}$

27 John Branden Little, "Band of Crusaders: American Humanitarians, the Great War, and the Remaking of the World" (PhD diss. in history, University of California (Berkeley), 2009), 110, note 129 .

28 Rockefeller Archives Center, Tarrytown, NY (hereafter RAC), Rockefeller Foundation Record (hereafter RF), RF Diaries, George E. Vincent, "Interview with Dr. Dorman of the Beirut Medical School 25 February 1924."

29 Cyrus Schayegh, "The Interwar Germination of Development and Modernization Theory and Practice: Politics, Institution Building, and Knowledge Production Between the Rock- 
Yet the Rockefeller Foundation remained reluctant to embark on a fullyfledged cooperation plan in the Middle East. The foundation required an assessment according to its own procedures of evaluation through an inspection tour by RF officials. The foundation as a whole postponed any contingency plan for the Near East colleges before an inspector of its own had made an assessment of the possibilities of medical cooperation. ${ }^{30}$ The foundation was undecided about when to start cooperation, which in a shifting regional and educational landscape meant about whether to cooperate at all.

\subsection{Cooperation and Secularization}

Strikingly, the colleges were eager to comply with RF demands in order to get out of financial problems and reexpand. Most effective was the scaling of the provision of aid, which enabled the RF, not only to impose its procedures of examination, but also to establish cooperation on a basis of external consensus on the goals of the RF-NECA project; this, despite the fact that it was actually reluctant to get involved in the Middle East for the time being, and did not have a clear plan for the region or the colleges.

The second step towards a common cooperation project saw the agreement of the Rockefeller Foundation around the medical sciences, in 1924, and a donation drive to complete it in 1925-1926. The head of Medical education at the foundation, Richard M. Pearce, and its director, George E. Vincent, undertook an inspection tour in the Middle East and were convinced by a well-prepared faculty at the American University of Beirut, as the SPC had been renamed in $1920 .{ }^{31}$ The foundation was setting its conditions and ended up imposing its timetable. Did these conditions pertain to the colleges' missionary character?

$\mathrm{RF}$ officials do not refer much to the missionary nature of the proposed cooperation in the Middle East. What they say and what they do, though, reflects a desire to avoid starting projects with openly missionary institutions.

In the Middle East as in China, missionary milieux were divided on the secularization of their work. Humanitarian action within the framework of the China International Famine Relief Commission and the NER and the prospect of cooperation with the Rockefeller Foundation were widening the gap. The division among missionaries in the Middle East overlapped with a division between missionary and more secular colleges, resulting in the limited list of

efeller Foundation and the American University of Beirut," Geschichte und Gesellschaft 41, no. 4 (October-December 2015): 669 .

$30 \quad$ AUB/ASC, A.A.7.6.2, AUBites, 9, "STAU B, A.w.," Box 2: Staub to Nickoley (February 17, 1923); Staub to Nickoley (April 24, 1923).

31 RAC, RF, RF Diaries, Richard M. Pearce (April 6, 1924); (May 22, 1924). 
the Near East colleges. Among the more missionary institutions stood out the American University in Cairo (AUC). ${ }^{32}$ The AUC was also home to some of the more vocal critics of the secularization of the AUB. ${ }^{33}$ The division between the colleges became a matter of money as the prospect of $\mathrm{RF}$ funding loomed.

The competition for funding reflected the preferences of the Rockefeller Foundation for secularized institutions and the notion it nurtured that these alone had a promising future in the Middle East. After the perimeter of the cooperation between the foundation and the Near East Colleges Association had been determined, a NER conference in Istanbul in 1927 would stress the uncertainties that the future held for the smaller, unfunded colleges. They were left with the choice between to continue teaching without aid, or to adapt to the $\mathrm{R} F$ agenda of rural development. ${ }^{34}$ In any case, the "three large institutions" which came had initially formed the Near East Colleges Association concentrated the financial resources-both on account of their secular outlook and of the guarantee of viability provided by their size.

The final list of the Near East colleges was not the result of a strategic plan, but a negotiated result, a group of institutions that not only could live with the secularized perspective of the Rockefeller Foundation but could organize to fulfil together a number of financial functions. The first goal of the small group formed by the Near East colleges was to coordinate the distribution of money and to avoid further internal conflicts. The immediate goal of this informal group was to distribute funds derived from the Charles M. Hall Estate, ${ }^{35}$ a massive donation to the ABCFM made upon his death by the aluminium magnate.

\subsection{Uneven Political Bases for Cooperation}

The Rockefeller Foundation was guided in its relations with the Near East Colleges Association by consideration of the local political situation first and foremost. The Foundation had been loath to invest in the Middle East as long as

32 Umar Ryad, "Muslim Response to Missionary Activities in Egypt: With a Special Reference to the Al-Azhar High Corps of Ulamâ (1925-1935)," in New Faith in Ancient Lands: Western Missions in the Middle East in the Nineteenth and Early Twentieth Century, Studies in Christian Mission 32, ed. Heleen Murre-van den Berg (Leiden: Brill, 2006), 281-307.

33 AUB/ASC, A.A.7.6.2, AUBites, 9, "STAU B, A.W.," Box 2, Nickoley to Staub (December 16, 1922).

34 Frank A. Ross, Charles L. Fry, and Elbridge Silbey, The Near East and American Philanthropy: A Survey, Conducted Under the Guidance of the General Committee of the Near East Survey (New York: Columbia University Press, 1929), 284.

35 RAC, RF, RF Diaries, Richard Pearce diaries (July 16, 1924); AUB/ASC, A.A.7.6.2, AUBites, 9, "Staub A.W.," Box 2, Staub to Dodge (October 16, 1924): Annex, "Five year financial program for Near East Colleges." 
uncertain political conditions prevailed. ${ }^{36}$ The intensified efforts of the trustees of the AUB in 1922-1923 and the repeated postponements by the foundation highlight the discrepancy between the reasons for the colleges to apply for RF aid and the foundation's criteria in granting it. The Rockefeller Foundation waited for the lull in military cooperation created by the Lausanne Treaty in July $1923,{ }^{37}$ before jumping on the occasion to start cooperation with the Near East colleges. It was making good of a narrow window of opportunity, following the military stabilization in Syria after the Lausanne treaty and before the Great Syrian revolt of the summer 1925. It sought to build on the goodwill manifested towards the AUB by the French High Commissioners, the heads of the French Mandatory administration, without antagonizing the Syrian population by working with the French colonizers. This was facilitated by the lack of interest of local French Catholic academic institutions for cooperation with American Protestant organizations.

The Rockefeller Foundation claimed to prioritize circumstances that allowed long-term plans, which required a favourable political environment. But here is the catch: RF and AU B officials did not see anything stable in that short period of relative calm, or in French rule for that matter. Rather, they were positioning themselves in view of the next, predictable round of confrontation, accepting the Mandatory regime while anticipating hostile trends in Syrian and Lebanese public opinion. In keeping with RF policy established in Europe, no cooperation was possible without cordial relations with the political authorities-indeed, without their participation. In Turkey, any cooperation that would seem to bypass the political authorities would have been viewed with suspicion by the Kemalist regime. ${ }^{38}$ The French Mandate, a Colonial republic under French tutelage but designed to have institutions of selfgovernment, was a different matter. As a state-in-the-making, it was of a hybrid, non-lasting nature. No pretence to favour long-term foreseeability would hold against that assessment, which makes it look as though the foundation entered full-scale cooperation headlong as soon as it could make sure it would not be seen as an intrusion by the powers-that-be.

A changing situation required caution vis-à-vis all actors concerned, not only the French, but Syro-Lebanese public opinion as well. Solidarity of American interests could only exist once that condition was fulfilled. The Rockefeller Foundation's approach was not to support American institutions in the Middle

\footnotetext{
36 AUB/ASC, A.A.7.6.2, AUBites, 9, "STAUB, A.W.," Box 2: Staub to Dodge (February 17, 1923).

37 Michael Provence, The Last Ottoman Generation and the Making of the Modern Middle East (Cambridge: Cambridge University Press, 2017), 155.

38 AUB/ASC, A.A.7.6.2, AUBites, 9, “StAUB, A.W.," Box 2: Moore to Dodge (April 6, 1924).
} 
East as a whole; ${ }^{39}$ but where it could support Americans, it would. The hybrid nature of the mandate provided a pretext to choose cooperation with the AUB: the criteria for cooperation devised by the foundation, namely, cooperation with local authorities, could be argued not to apply to the by definition external authority of the French Mandatory power. ${ }^{40}$

The assessment stressed the necessity to "go native" on every level. Pearce and Vincent completed it on their return to the United States with a report to the foundation on medical education in Syria. The French Jesuit Université Saint-Joseph, putting denominational belonging first and making do with catering for the needs of the Mandatory institutions anyway, would not cooperate. The Arab University of Damascus could not, for lack of equipment, staff, and academic standards. The AUB was blessed with a favourable image in the Middle East and a large hinterland of British colonies in the Middle East in need of English-speaking university-trained staff. ${ }^{41}$ Pearce and Vincent concluded by assessing that of the three institutions, the AU B had the best chances of middle-to-long-term survival. The conditions were ripe to strengthen the regional intra-American cooperation already functioning through the NER. Since the image of religious interference associated with missionary work had been dispelled, what was now required was to convince Syrians to make the AUB an institution of their own. This was one of the functions of the fundraising drive that followed the officialization of RF-Near East college cooperation.

\subsection{Changing Institutional Identities: Research Goals and Secular Outlook}

Another function of the Near East Colleges Association developed after 1927 with the expansion plan, namely, to provide coordination between the colleges in their relations with the Rockefeller Foundation. This facilitated the foundation's plan to transform the Near East colleges and the AUB in particular into research institutions aimed at preparing economic and social development. One condition for this was for the colleges to reach a critical mass enabling them to select researchers who would, in their time, be sent on fellowships to the United States and come back as trained researchers. ${ }^{42}$ This meant the colleges should not discourage potential Muslim students by displaying an openly Christian identity, as was still the case of Robert College and the ACG. ${ }^{43}$ Joint

Ross, The Near East in American Philanthropy, 285.

41 RAC, RF, FA 308, Box 551, File 3692: Richard M. Pearce, "Medical Education in Syria” (1924).

42 Schayegh, "The Interwar Germination," 654.

43 Ross, The Near East in American Philanthropy, 164. 
pressure to secularize would continue to be exerted by the trustees of the colleges, wary of missionaries; by the NER and later the Near East Foundation (NEF), with an experience in working with all denominations in spite of its clear Christian identity back home in America; and by the Rockefeller Foundation.

\section{Donors and Dependency}

Where did the Near East colleges get their funds from? Like a number of Protestant colleges in China, they were foundations established under the aegis of the ABCFM, which had historically provided the money for their creation, and worked with a network of patrician families that had made their ways into the boards of trustees of each and every college. Yet by the 1920s, the patterns and channels changed, with the arrival of philanthropies as a new type of major donor. Did the advent of the philanthropies' million-dollar grants change the approach of the colleges to funding? Especially, did it make them more responsive to pressure from donors? Did it differentiate them further from missionary institutions?

The end of the war and early post-war years were years of structural indebtedness for the Near East colleges. The economic situation made it impossible for them to maintain the principle of self-supportiveness that had been the norm. ${ }^{44}$

More preoccupying was the inadequacy between expenditure and supposedly corresponding sources of income. Boarding fees did not cover fully the overall boarding costs $(89 \%)$. Tuition fees covered less than half the expenditure for instruction $(48 \%)$. This went against a guiding principle of missions abroad, namely, that they should aim at being self-supportive and should at least cover their ordinary expenditure. With what money did the colleges survive, then?

\section{1}

The Traditional Way to Growth: Large Individual Donors

One of the central aspects of the work of the NER and of the RF involvement in the Middle East, beyond relief, was reconstruction. The word referred less to the localized effects of military destruction during World War I than to a massive effort of social engineering, among whose main tools was higher education. Pearce commented in 1925: "Syria is not Europe, the institution [the AUB] is fin-

$44 \mathrm{CUL} / \mathrm{RBML}, \mathrm{RC}, \mathrm{ACG}, \mathrm{Box} 3$, file 11: "Stated meeting of the trustees of the American College for Girls at Constantinople in Turkey, Held in New York City, Thursday, April 25, 1918." 
anced from America and the problem is not "emergency" in the sense of Central Europe, and I think the best term for the program is 'Wet nursing' ". 45 In the eyes of the foundation, external funding was sufficient to ensure the survival of the institution, but it was not enough to cover development, which also required specialized training.

$\mathrm{RF}$ practices of allying intensive funding and capacity building casts the foundation in opposition to earlier funding practices, especially nineteenthcentury ones. American gifts to the colleges meant first and foremost large individual gifts. These had long made the bulk of foreign missions' resources for investment, but the role of major donors had decreased through the 19th century: Sarah Flew shows with the case of major British foreign missionary societies such as the CMS that in the event of the loss of large individual donors, the society's operational capacity was no longer threatened. ${ }^{46}$ Missionary societies could rely on other sources of extraordinary income and remain afloat.

Gifts from large donors came with strings attached. Ideologically, donors expected missionary societies and protector states to stand for values compatible with theirs. Practically, most missionary societies preferred to reward major individual gifts with the naming of a piece of equipment, a room, or a building after the donor, rather than letting them retain bargaining power. Symbolic rewards were a way to minimize individualized donor dependency.

Under circumstances of financial emergency, missionary institutions saw no other option than to mobilize a network of well-to-do donors and accept their conditions. In 1922, the AUB negotiated a gift of $\$ 1$,ooo with a New Yorkbased immigrant originating from Damascus, N. Mallouk. The money was one example in a number of gifts destined to be used solely to fund scholarships for poor students - in particular Russian and Armenian refugees. ${ }^{47}$ In the Mallouk case, the condition was that it should help four students from Damascusthree Greek Orthodox and one Muslim — be selected for their academic proficiency and get an AUB education. ${ }^{48}$ Post-war emergency was liable to reinstate dependency on large individual donors, which the Near East colleges sought to avoid.

45 RAC, RF, Record Group 1.1 (hereafter: RG 1.1), box 2, file 11: Pearce to Carter (January 25, 1925).

46 Sarah Flew, Philanthropy and the Funding of the Church of England, 1850-1914 (London: Routledge, 2015), 138-139.

47 AUB/ASC, A.A.7.6.2, AUBites, 9, "StAUB, A.W." Box 2: Staub to Nickoley, (October 14, 1922).

48 AUB/ASC, A.A.7.6.2, AUBites, 9, "StAuB, A.W.", Box 2: copy of Walter Booth Adams to N.S. Mallouk (April 28, 1922). 


\subsection{Missions in the 19th Century and the Democratization of Funding}

Of course, missionary societies did not oppose large donors and small donors. The latter helped secure the operating costs of the missionary organizations, and establish them as major, reliable institutions. The reverse was true: large individual donors could be useful as models, in order to create larger pools of small donors, on a professional or communitarian basis for instance.

The mobilization of alumni soon highlighted the resources of the Middle Eastern diasporas. Branches of the alumni association were soon founded, not only across the Levant, but in North and South America as well. Prominent and affluent alumni would be useful in starting donation drives among the diasporas. ${ }^{49}$ Promises of grants, individual and institution, were supposed to have cumulative effects. ${ }^{50}$ The multiplication of branches of the alumni association abroad testified to the intrication of long-distance nationalism and professional links maintained through the alma mater.

The donation drive benefited from the conjuncture, as long-distance nationalism was aroused in the Syrian diasporas by the events in the French Mandate. Syrian public opinion abroad was turning against the French Mandatory power, especially after the beginning of the Great Syrian Revolt in the summer of 1925 . After the denunciation in the American press of the bombing of Damascus by the French in October 1925, ${ }^{51}$ the AUB and the United States were seen as political allies against French colonial exactions.

\subsection{State Subsidies and Influence}

"There is no such thing as a free lunch", as Milton Friedman put it, or gratuitous state subsidies for that matter; but they do not entail automatically donor-dependency on the state. Not only is the effectiveness of donor dependency indexed on the state's capacity of control over aid receivers, but state administrations are interventionist to varying degrees. In the Late Ottoman and Interwar period, France stood out as an example of diplomatic interventionism over missionary institutions placed under its protection, and the United States much less so. French governmental subsidies, given on a yearly basis on ministerial budget or out of the profits of the Pari Mutuel horse races, were carefully weighed at the Quai d'Orsay, strenuously negotiated, and often hotly

49 AUB/ASC, A.A.7.6.2, AUBites, 9, "STAUB, A.W.," Box 2: copy of Walter Booth Adams to N.S. Mallouk (April 28, 1922).

50 AUB/AsC, A.A.7.6.2, AUBites, 9, "Staub, A.w.," Box 2: Staub to Nickoley, (December 6, 1922).

$5^{1} \quad$ Susan Pedersen, The Guardians: The League of Nations and the Crisis of Empire (Oxford: Oxford University Press, 2015), 142-168. 
contested afterwards among disgruntled candidates. And yet even French diplomatic control over aid receivers had its limits. Individuals were able to carve their autonomy against consular and ambassadorial power, due to their connections within the church and the latter's complex balance of power. With the end of French monopoly on the protection of Latin Catholic missions in 1898 , Germany, Austria-Hungary, and Italy in particular started vying for the protection of "national" institutions through injecting subsidies, which in return meant closer oversight of their operations. ${ }^{52}$ Still, the relation worked both ways, and due to the international character of the Catholic religious staff, no situation of protection implied perpetual loyal or vertical power relations.

Us administrations seemed to keep a more hands-off policy towards missionary institutions than other Western powers. Personalities associated with missionary organizations were in close, frequent contacts with government officials, and humanitarian crises were a case when the us administration would summon missionary societies and their men on the ground to initiate relief operations. The establishment of the American Committee for Armenian and Syrian Relief was an instance of the relation working at the initiative of the government: together with fellow millionaire Charles Crane, patrician Cleveland Dodge, a close friend of us president Woodrow Wilson and the father of future AUв president Bayard Dodge, was called in 1915 by Us Ambassador to Constantinople Henry Morgenthau to form the American Committee for Armenian and Syrian Relief. ${ }^{53}$ Yet the correspondence between the trustees and the colleges shows them less often receiving orientations from the State Department than trying to assume an influence on us diplomacy. The letters exchanged between Albert Staub, the secretary of AUB's board of trustees, and the presidency of the AUB shows the former reacting upon political events with foreign policy implications: Staub cheers for the results of the midterms of 1922, seeing them as a payback for the Republicans' refusal to ratify the peace treaties and get a proactive role in the Middle East through the Armenia mandate. ${ }^{54}$ He is summoned to the us State Department following the signature of the Turco-American "Treaty of Amity and Commerce" signed in Lausanne in 1923

52 French Foreign Ministry Archives, Nantes, AP, Consulat de Beyrouth, Série A, 314, French Ambassador to the Holy See to Delcassé, Rome (May 8, 1902); Consulat de Beyrouth, Série A, 350, report: "Aperçu sur les œuvres diverses établies en Palestine et du moyen d' assurer et de développer l'influence française” [ca. 1903?].

53 Joseph L. Grabill, "Cleveland H. Dodge, Woodrow Wilson, and the Near East," Journal of Presbyterian History 48, no. 4 (Winter 1970): 255.

54 AUB/ASC, A.A.7.6.2, AUBites, 9, "STAUb, A.W.," Box 2: Staub to Nickoley (November 9, 1922). 
alongside the peace treaty between Turkey and Greece, but for advice. ${ }^{55} \operatorname{In} 1926$, he makes vain efforts to influence the Senate in favour of ratifying the treaty, ${ }^{56}$ which he sees as the condition for American institutions to go on working in Turkey, in the shadow of businessmen desirous to do business in Turkey. ${ }^{57}$ In line with these efforts at influencing policy, Staub devoted much time, alongside the organization of the donation drive of $1925^{-1926}$, to fleshing out the Newsletter of the Near East Colleges Association. The goal of the publication was first and foremost to give the colleges publicity and facilitate the collection of funds. But after the success of the donation drive for the contingency plan, Staub came to see the newsletter as a potential tool of influence. Rather than being funded and remote-controlled by the state, the Near East colleges sought deliberately to assume a role mixing lobbying and expertise vis-à-vis us diplomacy. Their capacity to collect donations boosted their political influence.

\section{4 "We Mean to Get the Million All Right": A Crowdfunding-Philanthropy Mix}

Why did the Near East colleges, with their traditional channels of funding and no dependency on the Us Treasury, apply in the early 1920s for RF money when it came with stringent procedures of control? As said before, the colleges were pressed for money. Moreover, cooperating with the Rockefeller Foundation was not exclusive of seeking other, more traditional sources of cash, in order to constitute a sufficient endowment and shore up its expanded budget. In this, the Near East colleges knowingly followed the model of their Chinese counterparts; yet the commitment of the foundation in the reorganization of medicine in China was also distracting it away from any serious investment in the Middle East.

Near East colleges officials understood RF grants to mean a jump in the financial resources at their disposal. The main aid receiver in the Middle East during the Interwar period, the AUB, ended up ranking in the middle among $\mathrm{RF}$ grantees of the period. ${ }^{58}$

$\mathrm{RF}$ money was a guarantee for other potential benefactors as well. The argument was used on N. Mallouk to encourage him into going through with his offer for scholarships: "[you] have probably seen what the Rockefeller Fund has

55 AUB/ASC, A.A.7.6.2, AUBites, 9, "STAUB, A.W.," Box 2: Staub to Dodge (April 12, 1924).

56 George Harris and Nur Bilge Criss, Studies in Atatürk's Turkey: The American Dimension (Leiden: Brill, 2009), 11.

57 AUB/ASC, A.A.7.6.2, AUBites, 9, "STAUB, A.W.," Box 3: Staub to Dodge, (September 23, 1926); Ibidem (January 25, 1927).

$5^{8}$ Schayegh, "The Interwar Germination," 66o. 
promised us and other interests are backing us. We mean to get the Million all right". ${ }^{9}$ What was the goal of the colleges, chasing two rabbits at a time, and were Rockefeller officials at home with that?

The Rockefeller Foundation was concerned with the capacity of the Near East colleges to find alternative sources of funding. The issue was double-edged. Banking on the fund-raising capacity of the Near East colleges to supplement $\mathrm{RF}$ funds ensured that the foundation did not have to bear the whole financial weight of the overhaul of the colleges. But multiple sources of fundings could make the colleges less responsive to RF control and pressure. At the beginning of the donation drive, Pearce expressed the latter view. He dismissed crowdfunding as the characteristic missionary way of fund-raising, and one that had proved problematic for the foundation elsewhere:

Your letter and their memoranda seem to show that they are after all they can get. I have always said that the American University of Beirout [sic] was not to be regarded as a Missionary Institution, but the present demands indicate that I was wrong: they seem to be after all they can get. ${ }^{60}$

The Near East Colleges Association's crowdfunding capacity was beneficial for their cooperation with the foundation. The reason Pearce was irked by the funding practices of the AUB was not its trying to preserve its autonomy through alternating among its benefactors, but the university's apparent treatment of the foundation as a cash machine and a publicity argument visà-vis other donors. It was RF policy to finance institutions so as to enable them to become self-supportive on a larger scale after RF-funded projects had ended.

But did RF grants facilitate or complicate the financial autonomy of the colleges? There was a case to be made for encouraging aid-receiving institutions to supplement $\mathrm{RF}$ fundings with donation drives, as this would, in time, minimize the effects of the transition out of aid and give institutions a basis of financial stability. The whole point of the $1925^{-1926}$ plan $^{61}$ and of the ensuing expansion plan ${ }^{62}$ was to clear the debts of the colleges first, and to constitute and consolidate an endowment to finance their expanded budget. There was a division

59 AUB/ASC, A.A.7.6.2, AUBites, 9, "Staub, A.W.," Box 2: copy of Walter Booth Adams to N.S. Mallouk (April 28, 1922).

6o RAC, RF, RG 1.1, Box 2/11: Richard M. Pearce to Walter S. Carter (January 25, 1925).

61 RAC, RF, RF Diaries, Richard Pearce diaries (April 6, 1924).

62 RAC, RF, RF Diaries, Richard Pearce diaries (June 3, 1927). 
of work. RF money would be concentrated on endowing the new equipments the foundation pressed for, and on developing medical and later social science teaching and research. ${ }^{63}$ The colleges committed themselves to finding the bulk of the money necessary to reconstitute and expand their endowment in order to receive $\mathrm{RF}$ funds. ${ }^{64} \mathrm{RF}$ funds and other sources of funding were not alternatives: they conditioned one on another.

The foundation exerted pressure on the process of donation collection, but not on the methods, which ended up being what Pearce had called "missionary" - based on partly missionary networks and, above all, on crowdfunding. The scale of RF funding was a pull factor for donors and an incentive for the trustees of the colleges to step up the campaign directed at potential donors. Alongside the newsletter of the Near East colleges, publicity, and conferences, an Oriental bazaar was organized to kickstart the donation drive at the end of 1924, with the sale of products from Armenian refugee and Syrian charities and the participation of notable figures in the missionary world, as well as George Vincent. ${ }^{65}$

The colleges maintained their traditional missionary ways of collecting funds, but even on these the foundation exerted oversight. The relation was more of control than of dependency: the complementarity between the modes of funding was aimed, not just at anticipating the transition out of RF projects, but already at preventing RF money from becoming part of the ordinary budget of the colleges. The foundation considered that they should become self-supporting again as soon as possible. Was pressure on funding used as efficiently on the expenditure of the colleges? Were the colleges as subservient to the specific agendas of the foundation as they were to the financial conditions it laid down?

The notion of agenda-dependency can be used to describe the creation of aid-induced obligation to enforce the agendas of the donor, but this can refer to two forms of obligation: effective compliance (performance obligation) or demonstration of steps taken towards compliance (best-efforts obligation). Failure to comply does not necessarily entail the end of cooperation, which

63 RAC, RF, RF Diaries, Richard Pearce diaries (May 22, 1924).

64 AUB/ASC, A.A.7.6.2, AUBites, 9, "STAUB, A.W.," Box 2: Staub to Dodge (May 23, 1924).

65 AUB/ASC, A.A.7.6.2, AUBites, 9, "Staub, A.W.," Box 2: Moore to Crawford (December 26, 1924). 
would deprive donors of power over aid receivers. However, the stress of early 2oth-century economics on budget orthodoxy put pressure on economic actors, both public and private, to strive towards budget balance, and therefore to get out of debt as quickly as possible. This made donor-receiver relations more comminatory. The influence of the Rockefeller Foundation was mostly felt on the expenditure side, where it could impose its norms and its agendas. The insider knowledge held by Near East colleges officials often enabled them to anticipate its demands, but the foundation was in the habit of threatening to withhold or fail to renew its grants in order to bring aid receivers back in line. RF-funded projects were devised so as not to induce a structural need for aid in the budget of receiver institutions; the counterpart was that the pressure on enforcing the foundation's recommendations was direct. In the case of the Near East colleges, compliance to RF norms had its limits; but cooperation had a broader, more structural influence by bringing about a rationalization of expenditure.

The Rockefeller Foundation was more involved in the architecture of training and research than in individual cases, which led it to exert an influence on the disciplines and the contents taught in the Near East colleges. Whereas missionary schools and colleges sought to instill, if not an outright religious morality, at least one clearly influenced by Protestantism, ${ }^{66}$ the foundation was more interested in instilling in students deontology and professional procedures. $^{67}$

\section{Professionalizing the Staff: Focusing on Professional Procedures, a} Secularization of Recruitment?

Another focus of RF pressure was the standardization of professional procedures. Sending students and alumni on scholarship to the United States served the purpose, among other goals. So did the inspection tours that followed the establishment of cooperation between the foundation and the colleges. At the decisional level, it created stronger relations between the authorities of the colleges and globalized, though largely Western, scientific communities.

Did the Rockefeller Foundation's preference for work with secularized institutions translate into pressure regarding recruitment policy? The answer is not clear cut. First, cross-denominational recruitment did not make sense from the

66 Boulos, European Evangelicals in Egypt, 131-137.

67 Schayegh, "The Interwar Germination," 671. 
point of view of the foundation alone, but also for the colleges themselves. This was due to the ambiguities and evolutions of the notion of religious freedom as promoted by the us government and American private voluntary organizations alike. Religious freedom had become an argument for the us diplomacy to support missions in the late Ottoman Empire. ${ }^{68}$ It had meant a guarded support for missionary proselytizing as well as support for coexistence between Muslim and non-Muslim communities in the face of growing inter-communal violence. Yet by the time the Near East Colleges Association and the Rockefeller Foundation formalized their cooperation, circumstances had changed beyond recognition. First, religious freedom had been weaponized against missionary institutions, in the case of the 1909 student strike at the SPC: non-Christian students had invoked it in order to be exempt of the obligation of attending Bible classes and religious service. ${ }^{69}$ Then, with the mass violences of World War I and the post-war conflicts, the non-Muslim population of the new state of Turkey had all but disappeared and the Kemalist authorities used their own notion of laiklik (secularism) and the new demographic composition of the country against Christian missions. ${ }^{70}$ Invoking religious freedom could work to justify the uncomfortable but ongoing presence of missionary institutions on Turkish territory, but not the protection of proselytizing institutions; hence the urgent need of the American colleges in Istanbul to integrate Turkish staff in their midst. In Beirut, on the contrary, power had been seized by a state identified alternately as secular and Christian. Active Protestant proselytism would antagonize the majority of the population of the Mandate, but promoting religious coexistence and interactions in the name of religious freedom was an effective tool of cultural diplomacy in order to conquer local public opinion. ${ }^{71}$

Yet in practice, most of the Western candidates and recruitees of the Near East colleges had a missionary past or family. Not only were they referred to that pedigree in the international correspondence of the Near East Colleges Association and in letters to the Rockefeller Foundation; their missionary history was

68 Henry Otis Dwight, Treaty Rights of American Missionaries in Turkey (New York: Foreign Missions Library, 1893), 7 .

69 Jens Hanssen, Fin de Siècle Beirut: The Making of an Ottoman Provincial Capital (Oxford: Clarendon Press, 2005), 186.

70 Rufat N. Bali, The Saga of a Friendship:Asa Kent Jennings and the American Friends of Turkey (Istanbul: Libra, 2009), 335 .

71 Jennifer Dueck, "International Rivalry and Culture in Syria and Lebanon under the French Mandate," in Searching for a Cultural Diplomacy, eds. Jessica C.E. Gienow-Hecht and Mark C. Donfried (New York: Berghahn, 2013), 137-161. 
seen as of value to work in the Middle East. ${ }^{72}$ This preference in the face of outward assertions of religious freedom and repudiation of missionary methods cannot be reduced to a hidden agenda of cultural influence and subterranean religious propaganda. Three other factors at least have to be taken into account. The first one lies in the professional qualities attributed to missionary, to wit, a "spirit" full of enthusiasm, associated with an experience of foreign fields. ${ }^{73} \mathrm{The}$ second factor is financial, as missionaries were assumed to be liable to accept the salaries paid by the Near East colleges, whose reduced amount in comparison with similar work in the United States explains much of the high turn-over among the Western staff. ${ }^{74}$ Lastly, hiring staffers of missionary background was also thought as a way to prevent what was the alternative way to prevent the turn-over of Western teachers in the medical sciences, namely, allowing them to keep a private practice by the side. The practice was common among missionary medical schools abroad, but it ran against the RF goal of developing institutions of research. At the Peking Union Medical College, the main focus of RF medical projects in China, Pearce had been able to observe the problem: "I feel that if the present policy is to continue there will be great danger of establishing a Mayo clinic with a medical school attached".75 At AUB, Rockefeller fellowships were one way to steer practitioners away from their private practices and back to research. ${ }^{76}$

The relationship that developed between the Rockefeller Foundation and the Near East Colleges Association during the Interwar period was clearly one of influence. The foundation exerted influence on both an individual and a strategic level, be it on priorities of academic development, politics, staff recruitment, or conceptions of social engineering. By and large, the administrations of the colleges welcomed RF involvement through higher standards and the goal of becoming research institutions. The result was not equally satisfactory for all colleges, though, as the AUB was given a prominent role above consid-

72 See for instance: RAC, RF, Pearce diaries (September 19, 1924); Mary Beard, (October 24, 1927); (December 2, 1927); AUB/ASC, A.A.7.6.2, AUBites, 9, "STAUB, A.W.," Box 3, Staub to Dodge (August 31, 1926).

73 RAC, RF, Pearce diaries (December 2, 1927).

74 AUB/ASC, A.A.7.6.2, AUBites, 9, "STAUb, A.W.," Box 2, Staub to Dodge (August 11, 1924).

75 RAC, RF, Pearce diaries (February 14, 1921).

76 AUB/ASC, A.A.7.6.2, AUBites, 9, “StaU B, A.W.," Box 2, Nickoley to Staub (May 21, 1923). 
erations for regional governments, whereas the colleges in Istanbul saw their academic perimeter curbed by RF consideration of the nationalist government of the Republic of Turkey: in 1925, the ACG had to close down its brand new medical school for women under RF pressure, and as a display of goodwill to the Kemalist authorities.

RF influence was obtained through an open carrot-and-stick approach, based on the promise of funding. The Near East colleges appear to have been more than willing to submit to RF procedures and injunctions, plagued as they initially were by ordinary expenditure debts and the cost of their relief activities. They were less reluctant than their counterparts in China to adhere to RF methods and forgo openly missionary identities. Philanthropy funding completed the evolution out of religious proselytism which had been accelerated by the colleges' wartime and post-war humanitarian repurposing.

In the process of negotiating cooperation and afterwards, the Near East colleges made use of their image as being less missionary and more secular than most other American Protestant institutions in the region. While the Rockefeller Foundation was not anti-missionary, it had become wary, through its work in China, of missionaries attempting to maintain the priority of their religious calling. I argue, however, that missionary meant different things in different contexts: the foundation saw the epithet in a positive light when it referred to the genealogy of American recruitees, their values and their field experience abroad, in humanitarian action especially; with discomfort as to actual proselytizing; and with ambivalence when it came to funding methods. The religious identification of the aid-receiving institutions mattered to the foundation as a donor, and the more proactive missionaries were spared dependency on it, at the price of protracted shortage of cash. Sticking to one's religious values did make a difference. Yet the relation of causality-that secularization would have helped make the Near East colleges dependent on RF money - fails to apply the other way around. The Near East colleges retained its Christian missionary inspiration on the inside, out of sight. Its proactive subservience to the recommendations of the foundation did not stem from a conversion to secular values, but from a sense of opportunity for higher education in the Middle East, and from insider knowledge about the demands of the foundation, thanks to relations with American Colleges in China.

For these reasons, the RF-NECA relationship can be characterized by agenda dependency, but cannot be assimilated to the kind of subservience to donors which contemporary NGOs are commonly denounced for. Agenda dependency, in this instance, followed and pushed further the dropping of the colleges' missionary agenda and the recasting of their religious identity into that of beacons of religious freedom. The success of the donation drives organized 
by the boards of trustees of the colleges do not indicate a loss of support or confidence in their operational norms or in their adherence to their original Protestant values. These drives did not curtail RF influence on the agenda of the colleges in the short run either, coordinated as they were with Rockefeller authorities. But they guaranteed the capacity of the colleges to grow out of dependency on RF funding in the long run. The situation at hand is different from present-day patterns of donor dependency, in which NG O s and other institutions come to need on a regular basis continued support from an institutional donor, to whom they become subservient; RF influence on the Near East colleges had a horizon: its emergency plans and grants for reconstruction were understood to be as temporary as possible. The goal, reflecting a lingering Victorian ideal of self-reliance, was to kick-start institutions meant to become self-supporting. There was an entry cost for the Near East colleges, who had to submit to RF procedures of evaluation. Yet as the case of the AUB and its rival institutions in Beirut and Damascus shows, the effort promised to pay off. The missionary practice of crowdfunding did not offset RF influence, it made the temporary character of $\mathrm{RF}$ aid a realistic perspective. Nowadays, aid attribution is competitive, which creates relations of clientele: aid receivers cultivate the good will of their donors. The procedural costs of submitting a grant application make it an investment, the viability of which depends on reconduction. The depth and nature of donor dependency change with the time frame of aid ${ }^{77}$ and the degree of competition for funding. With little competition surrounding the Near East colleges, it did little matter to their American benefactors how strongly Protestant and missionary those institutions came out.

And now, to get back to the issue of the role of missions in American strategies. The archives show the trustees of the Near East Colleges Association actively attempting to influence American foreign policy, rather than being given directions from Washington. Presuming one strategy guiding the Rockefeller Foundation and the colleges runs against the fact that there were roads not taken and cul-de-sacs such as the medical school of the ACG, reciprocal interrogations on the intents of the various actors involved, and ambiguities on the goals to be attained. While the Rockefeller Foundation was set on rural development and this goal was by and large accepted by the AUB, national governments in the Middle East nurtured other plans for the graduates they recruited. The foundation, determined to cooperate directly with the Turkish government, probably came upon difficulties in trying to impose such an 
agenda on the colleges in Istanbul, as the Kemalist régime wanted to industrialize the country and bring Western firms and experts to that end. Moreover, the convergence of operations between American private voluntary organizations in the Middle East and philanthropies was not an abstract view. It was experienced in the field, in the emergency and relief work. The relations between the Rockefeller Foundation, the Near East College Association and the NER were sites of production of techniques of cooperation that would later be institutionalized within the us State Department and, much later still, be identified as a specific form of power within international relations: soft power. Even regarding a major American ideological export product, religious freedom, the agency of the colleges should be separated from the strategies of the Rockefeller Foundation, let alone of the American government. Vis-à-vis this agenda, American diplomacy was an enabler, creating the position of diplomatic privilege under which the Near East colleges could work. The content of the agenda was left in the hands of other actors, rather than being channelled through them as part of a larger strategy and a common national agenda. ${ }^{78}$ The Rockefeller Foundation promoted religious freedom from a perspective of efficiency in predominantly non-Christian settings in China and the Middle East, together with a growing distrust, gained in China, with the spirit of denominational exclusivity displayed by certain missionaries. The Near East colleges themselves were wary of hurting local public opinion, and against a backdrop of more proactive missions working in the region, gave religious freedom the meaning of non-interventionism on the part of Protestant institutions, religious coexistence in their midst, as well as deontology and character training under clear but unspoken influence of Protestant ethics for their students. This way, they could claim to their financial backers to remain true to their Christian values while creating a pattern of interdenominational cooperation that would also become part of us modernization policies.

78 On the distinction between the "subjective", strategic exertion of power and the "objective" power given by a position of privilege, and the idea that the assumed non-intrusive character of "soft power" as conceptualized by Joseph Nye is often undermined by active exertion of power, see Edward Lock, "Soft Power and Strategy: Developing a 'Strategic' Conception of Power," in Soft Power and us Foreign Policy: Theoretical, Historical, and Contemporary Perspectives, ed. I. Parmar and M. Cox (London: Routledge, 2009), 32-50. 


\section{Bibliography}

\section{Primary Sources}

American University of Beirut. Archives and Special Collections (AUB/ASC).

Boğaziçi Üniversitesi Archives, Istanbul (CUL/RBML, RC).

American College for Girls Records (ACG). Box 20, file 18: President's Report with Statistics 1920-1921.

Rockefeller Archives Center (RAC). Tarrytown, New York.

Rockefeller Foundation Record (RF).

\section{Secondary Sources}

Abu-Sada, Caroline. oNG Palestiniennes et construction étatique: L'expérience de Palestinian Agricultural Relief Committees (PARC) dans les Territoires occupés palestiniens 1983-2005. Beyrouth: Presses de l' IFPO, 2013.

Baick, John S. "Cracks in the Foundation: Frederick T. Gates, the Rockefeller Foundation, and the China Medical Board." The Journal of the Gilded Age and Progressive Era 3, no. 1 (2004): 59-89.

Bali, Rufat N. The Saga of a Friendship: Asa Kent Jennings and the American Friends of Turkey. Istanbul: Libra, 2009.

Beaumont, Peter. "Israel Passes Law to Force NGos to Reveal Foreign Funding." The Guardian, July 12, 2016. Accessed on April 27, 2018. https://www.theguardian.com/ world/2016/jul/12/israel-passes-law-to-force-ngos-to-reveal-foreign-funding.

Boulos, Samir. European Evangelicals in Egypt (1900-1956): Cultural Entanglements and Missionary Spaces. Studies in Christian Mission 48. Leiden: Brill, 2016.

Cook, Albert. "Medical Itineration." Mercy and Truth vol. 5, no. 66 (June 1902): 174179.

Crabtree, Loren W. "Andrew P. Happer and Presbyterian Missions in China, 1844-1891." Journal of Presbyterian History 62, no. 1 (Spring 1984): 19-34.

Dueck, Jennifer. "International Rivalry and Culture in Syria and Lebanon under the French Mandate." In Searching for a Cultural Diplomacy, edited by Jessica C.E. Gienow-Hecht and Mark C. Donfried, 137-161. New York: Berghahn, 2013.

Dunch, Ryan. "Science, Religion, and the Classics in Christian Higher Education to 1920." In China's Christian Colleges, edited by Daniel Bays and Ellen Widmer, 57-8o. Stanford: Stanford University Press, 2009.

Dwight, Henry Otis. Treaty Rights of American Missionaries in Turkey. New York: Foreign Missions Library, 1893.

Ekbladh, David. The Great American Mission: Modernization and the Construction of an American World Order. Princeton: Princeton University Press, 2010.

Flew, Sarah. Philanthropy and the Funding of the Church of England, 1850-1914. London: Routledge, 2015 . 
Gardey, Delphine. Ecrire, Calculer, classer: Comment une révolution de papier a transformé les sociétés contemporaines, 1800-1940. Paris: La Découverte, 2008.

Grabill, Joseph L. "Cleveland H. Dodge, Woodrow Wilson, and the Near East." Journal of Presbyterian History 48, no. 4 (Winter 1970): 249-264.

Gür, Asl. "Robert College: Laboratory for Religion, Shrine for Science-Transculturation of Evangelical College Model in Constantinople." In American-Turkish Encounters: Politics and Culture (1830-1989), edited by Nur Bilge Criss, Selçuk Esenbel, Tony Greenwood, and Louis Mazzari, 48-6o. Newcastle upon Tyne: Cambridge Scholars Publishing, 2011.

Hanssen, Jens. Fin de Siècle Beirut: The Making of an Ottoman Provincial Capital. Oxford: Clarendon Press, 2005.

Harris, George, and Nur Bilge Criss. Studies in Atatürk's Turkey: The American Dimension. Leiden: Brill, 2009.

Harris, Paul W. "Cultural Imperialism and American Protestant Missionaries: Collaboration and Dependency in Mid-Nineteenth-Century China." Pacific Historical Review 6o, no. 3 (August 1991): 309-338.

Hauser, Julia. German Religious Women in Late Ottoman Beirut: Competing Missions. Coll. "Studies in Christian Missions." Leiden: Brill, 2015.

Human Rights Watch. "Egypt: New Law Will Crush Civil Society," June 2, 2017. Accessed April 27, 2018. https://www.hrw.org/news/2017/o6/o2/egypt-new-law-will-crush-civ il-society.

Kennedy, Charles H., Ijaz Hussein, and S. Akbar Zaidi. "Reconsidering the Relationship between the State, Donors, and NGos in Bangladesh [with Comments]." The Pakistan Development Review 38, no. 4 (Winter 1999): 489-510.

Lankester, A. "Some Observations on General Mission Policy." Mercy and Truth vol. 1, no. 10 (October 1897): 219-223.

Lankester, H. "Medical Missions in Theory." Mercy and Truth vol. 3, no. 38 (February 1900): 37-42.

Lautz, Terril E. "The svm and Transformation of the Protestant Mission to China." In China's Christian Colleges: Cross-Cultural Connections, 1900-1950, edited by Daniel Bays and Ellen Widmer, 3-19. Stanford: Stanford University Press, 2009.

Lefebvre, Jeffrey A. "Donor Dependency and American Arms Transfers to the Horn of Africa: the F-5 Legacy." The Journal of Modern African Studies 25, no. 3 (September $1987): 465-488$.

Little, John Branden. "Band of Crusaders: American Humanitarians, the Great War, and the Remaking of the World." PhD diss. in history, University of California (Berkeley), 2009 .

Lock, Edward. "Soft Power and Strategy: Developing a 'Strategic' Conception of Power." In Soft Power and Us Foreign Policy: Theoretical, Historical, and Contemporary Perspectives, edited by I. Parmar and M. Cox, 32-50. London: Routledge, 2009. 
Maksudyan, Nazan. Orphans and Destitute Children in the Late Ottoman Empire. Syracuse, NY: Syracuse University Press, 2014.

Mills Patrick, Mary. A Bosphorus Adventure: Istanbul (Constantinople) Woman's College, 1871-1924. Stanford: Stanford University Press, 1934.

Near East Relief. Report to Congress for 1925. New York: Near East Relief-National Headquarters, 1926.

Petersen, Marie-Juul. For Humanity or for the Umma? Aid and Islam in Transnational Muslim NGOs. Oxford: Oxford University Press, 2016.

Pedersen, Susan. The Guardians: The League of Nations and the Crisis of Empire. Oxford: Oxford University Press, 2015.

Provence, Michael. The Last Ottoman Generation and the Making of the Modern Middle East. Cambridge: Cambridge University Press, 2017.

Ross, Frank A., Charles L. Fry, and Elbridge Silbey. The Near East and American Philanthropy: A Survey, Conducted Under the Guidance of the General Committee of the Near East Survey. New York: Columbia University Press, 1929.

Ryad, Umar. "Muslim Response to Missionary Activities in Egypt: With a Special Reference to the Al-Azhar High Corps of Ulamâ (1925-1935)." In New Faith in Ancient Lands: Western Missions in the Middle East in the Nineteenth and Early Twentieth Century. Studies in Christian Mission 32, edited by Heleen Murre-van den Berg. Leiden: Brill, 2006.

Schayegh, Cyrus. "The Interwar Germination of Development and Modernization Theory and Practice: Politics, Institution Building, and Knowledge Production Between the Rockefeller Foundation and the American University of Beirut." Geschichte und Gesellschaft 41, no. 4 (October-December, 2015): 649-684.

Sharkey, Heather J. "Introduction: The Unexpected Consequences of Christian Missionary Encounters." In Cultural Conversions: Unexpected Consequences of Christian Missionary Encounters in the Middle East, Africa, and South Asia, edited by Heather J. Sharkey, 1-26. Syracuse, NY: Syracuse University Press, 2013.

Ventura, Lorella. Hegel in the Arab World: Modernity, Colonialism, and Freedom. London: Palgrave MacMillan, 2018.

Vincent, George E. The Rockefeller Foundation. A Review for 1919. Public Health and Medical Education in Many Lands. New York: The Rockefeller Foundation, 1920.

Wang, Dong. Managing God's Higher Learning: U.S.-China Cultural Encounters and Canton Christian College (Lingnan University) 1888-1952. Lanham, MD: Lexington Books, 2007.

Watenpaugh, Keith David. Bread from Stones: The Middle East and the Making of Modern Humanitarianism. Berkeley: University of California Press, 2015. 


\title{
"Machine Age Humanitarianism": American Humanitarianism in Early-2oth Century Syria and Lebanon
}

\author{
Idir Ouahes
}

Historians of humanitarianism have increasingly scrutinized its social and political perspectives in the hope of defining a unitary field of study. One trend has sought to emphasize the pre-existing contexts prior to the formalization of humanitarian activity. ${ }^{1}$ Other accounts, such as Michael Barnett's, suggest that humanitarianism as a concept should be considered separately from traditional charity since it is a particularly modern, Western phenomenon that emerged from Enlightenment ethics (transcendentalism and universalism) ${ }^{2}$

In the Middle Eastern context, Ottoman-era massacres have generated the most attention. ${ }^{3}$ Historians of the Middle East have nevertheless also sought to emphasize the well-established Islamic charitable experience. Islamic awqāf (mortmain perpetuities) have been an intrinsic part of the region's humanitarian activity. ${ }^{4}$ These Islamic financial instruments provided for a range of charitable activities, even for the protection of birds as was the case in a Fezzan waqf.

1 Peter Stamatov, The Origins of Global Humanitarianism: Religions, Empires, and Advocacy (Cambridge: Cambridge University Press, 2013). Stamatov and earlier historian Frank Klingberg nevertheless recognize the importance of the slavery abolitionists in giving impetus to humanitarianism and forging the domestic welfare state. See Stamatov, The Origins, 155-172; Frank J. Klingberg, "The Evolution of the Humanitarian Spirit in Eighteenth-Century England," The Pennsylvania Magazine of History and Biography 66, no. 3 (July 1942): 26o-278. David Forsythe notes the parallels between Henry Dunant's International Committee of the Red Cross, set up in 1859, and London's Anti-Slavery Society, founded in 1839. See David P. Forsythe, The Humanitarians: The International Committee of the Red Cross (Cambridge: Cambridge University Press, 2005), 14-16.

2 Michael N. Barnett, Empire of Humanity: A History of Humanitarianism (Ithaca, NY: Cornell University Press, 2013).

3 Michelle Elizabeth Tusan, Smyrna's Ashes: Humanitarianism, Genocide, and the Birth of the Middle East (Berkeley and Los Angeles, CA: University of California Press, 2012); Davide C. Rodogno, Against Massacre: Humanitarian Interventions in the Ottoman Empire, 1815-1914 (Princeton, NJ: Princeton University Press, 2012).

4 Jamal Krafess, "The Influence of the Muslim Religion in Humanitarian Aid," International Review of the Red Cross 87, no. 858 (June 2005): 327-342. 
Addressing this range of activity, some historians have argued that they provided cover for rent-seeking urban elites holding rural land, while others have portrayed such legal instruments as the backbone of Islamic social welfare. ${ }^{5}$ What is clear is that this charity was not simply about "just giving". As Nefissa Naguib and Inger Marie Okkenhaug have noted: "[Islamic] welfare defined too restrictive as a bureaucratic or religious activity would simply be too narrow to grasp issues and realities". ${ }^{6}$

Although these pre-existing charitable experiences and the difficulty in definitions should be carefully considered, there was a definite shift in the scope and character of Middle Eastern humanitarianism as the Ottoman Empire crumbled and European colonial mandates emerged in the region. Keith Watenpaugh's recent work on post-World War I Middle East humanitarianism has emphasized the modernity of the American humanitarian response. Religious institutions coalesced their charitable and developmental efforts in the region during the War and became increasingly bureaucratized and technocratic, a theme that resonates in the present study. ${ }^{7}$ Although Watenpaugh's research is an important overview of this phenomenon in the modern Middle East, it should be read as a call to further scholarly investigation rather than a "final word" on the phenomenon.

The present research both supports and refines Watenpaugh's overview of modern humanitarianism. Unlike Watenpaugh's contribution, it does not rely on an intrinsically modernist understanding of humanitarianism, drawn from Michael Barnett's views. Instead, it suggests that there was plurality of constructions and understandings of humanitarianism; not only did the Ottoman and earlier Islamic approaches differ from the European ones, so too did the American "Machine Age" approach rolled out by Near East Relief show significant distinctions from its European peers due to the bureaucratization, limited Orientalism, and other factors discussed below. Finally, this study adds empirical knowledge relating to the case of French Mandate Syria during the InterWar era; Watenpaugh's work geographically focused on Turkey and other "core" Ottoman domains.

5 Jonathan Benthall and Jerome Bellion-Jourdan, The Charitable Crescent: Politics of Aid in the Muslim World (London: I.B. Tauris, 2003), 29-35; Michael Bonner, Mine Ener, and Amy Singer, Poverty and Charity in Middle Eastern Contexts (Albany, NY: SUNY Press, 2003).

6 Nefissa Neguib and Inger Marie Okkenhaug, "Introduction," in Interpreting Welfare and Relief in the Middle East, eds. Nefissa Naguib and Inger Marie Okkenhaug (Leiden: Brill, 20o8), 4.

7 Keith David Watenpaugh, Bread from Stones: The Middle East and the Making of Modern Humanitarianism (Berkeley and Los Angeles, CA: University of California Press, 2015). 
More broadly, one review of the humanitarian literature has noted that: "Humanitarianism intertwined religious and secular dimensions". Such a "modern" humanitarianism was also the result of the increasingly international public sphere emerging from the post-World War period. ${ }^{9}$ Watenpaugh also suggests that the League of Nations' efforts, which was the theoretical overseer of France's mandate, acted as a cauldron for the rise of modern, permanent and preventative, humanitarian missions. ${ }^{10}$

Organized U.s. humanitarian intervention enabled the creation of local constituents, including those involved with distributing aid to those receiving it. This led French mandatory authorities to suspect American intentions; with some justification. French fears were compounded due to the clashing culture between American welfare activity, with its emphasis on "scientific" management run by executives, and traditional French clientelism. On the other hand, the core economic burden taken on by the Americans was effectively relieving the French mandatory authorities from some of the welfare obligations that went hand-in-hand with the mandate's state-building mission.

The following analysis examines a range of U.s., French, and British diplomatic archives as a well as a range of U.s. humanitarian institutions' archives drawn from East Coast colleges and historical societies. This approach provides greater depth of examination of these religious and humanitarian institutions' activities in Syria during the 1920s; thus complementing existing coverage of their roles in the 19th century. The combination of state and non-state archives also brings to light the politically charged operating environment that humanitarian assistance in Syria and Lebanon represented. Though Ottomanera humanitarianism would have inevitably been subject to Ottoman governmental scrutiny and u.s. diplomatic support, there was a marked increase in the level of political interest in the post-World War period.

Johannes Paulmann recently suggested that future analysis should: "further historical investigation of the fundamental structural dilemmas of aid ... the relationship between donors and beneficiaries ... the effects that moral, eco-

8 Johannes Paulmann, "Conjunctures in the History of International Humanitarian Aid during the Twentieth Century," Humanity: An International Journal of Human Rights, Humanitarianism, and Development 4, no. 2 (2013): 217.

9 Susan Pedersen, The Guardians: The League of Nations and the Crisis of Empire (Oxford: Oxford University Press, 2015); Erez Manela, The Wilsonian Moment: Self-Determination and the International Origins of Anticolonial Nationalism (Oxford: Oxford University Press, 2007).

10 Keith Watenpaugh, "The League of Nations' Rescue of Armenian Genocide Survivors and the Making of Modern Humanitarianism, 1920-1927," American Historical Review 115, no. 5 (2010): 1315-1339. 
nomic, political ... aid ... had on the resilience ... of the societies ... [and] approach the history of humanitarian aid in a polycentric multilayered way ... from local/national and international perspective".1 The present work answers this call by revealing how "Machine Age humanitarianism" in 1920s Syria and Lebanon encouraged the creation of connected constituents who could rely on U.s. aid while financially relieving the French mandate authorities from their League of Nations-approved task of building a functioning modern state. The longer-term impact on Syrian social relations with the state can be inferred, via further research along the lines of that undertaken by Ellen Fleischmann with respect to female identities can provide more concrete evidence. ${ }^{12}$

\section{1 \\ The American Humanitarian Impulse in Syria}

Keith Watenpaugh's recent overview reveals the scope of American humanitarian engagement with the region. It provides an important corrective to a tendency to skip over 2oth-century American humanitarian engagement with the region..$^{13}$ The American humanitarians were united by an evident, if at times Orientalist, passion for supporting local peoples. American Protestant institutions founded schools, hospitals, and orphanages. ${ }^{14}$

The greatest of these institutions, the American University of Beirut (AUB), was founded in 1866 by the Presbyterian Bliss family. ${ }^{15}$ Although the AUB would evolve in complex ways, as Betty Anderson demonstrates, smaller Protestant

\footnotetext{
11 Paulmann, "Conjunctures," 230.

12 Ellen Fleischmann, "The Impact of American Protestant Missions in Lebanon on the Construction of Female Identity, c. 1860-1950," Islam and Christian-Muslim Relations 13, no. 4 (2002): 411-426; Ellen Fleischmann, "Lost in Translation: Home Economics and the Sidon Girls' School of Lebanon, c. 1924-1932," Social Sciences and Missions 23, no. 1 (2010): 32-62.

13 Olivier Zurz only mentions Near East Relief twice in his overview. Olivier Zurz, Philanthropy in America: A History (Princeton, NJ: Princeton University Press, 2012). See also Robert L. Daniel, American Philanthropy in the Near East, 1820-1960 (Athens, он: Ohio University Press, 1970); Ussama Makdisi, Artillery of Heaven: American Missionaries and the Failed Conversion of the Middle East (Ithaca, NY: Cornell University Press, 2008).

14 See, for instance, Ellen Fleischmann, "Evangelization or Education: American Protestant Missionaries, the American Board, and the Girls and Women of Syria (1830-1910)," in New Faith in Ancient Lands: Western Missions in the Middle East in the Nineteenth and Early Twentieth Centuries, ed. Heleen Murre-van den Berg (Leiden: Brill, 2006), 263-28o; Christine B. Lindner, "Negotiating the Field: American Protestant Missionaries in Ottoman Syria, 1823 to 186o" (PhD diss., University of Edinburgh, 2009).

15 Betty S. Anderson, The American University of Beirut:Arab Nationalism \& LiberalEducation (Austin, Tx: University of Texas Press, 2011).
} 
institutions were primarily proselytizers. The earliest American humanitarian impulses sought to save Christian communities such as the Armenians. This was the case for the American Red Cross, which responded to late-Ottoman "Hamidian" massacres of Armenians in the 1880s and continued these efforts throughout the 189 os. ${ }^{16}$

Another sign of the religious impulse of pre-World War efforts is evidenced by the fact that humanitarian organizations did not circumscribe themselves according to national divides. A case in point concerns two British Quakers, Daniel and Emily Oliver, who ran a refugee school at Souq Al-Gharb in Lebanon. ${ }^{17}$ In 1914, Daniel Oliver, representing the Friends' Foreign Mission Association wrote to inform Herbert Welsh, an American Quaker in Westtown Pennsylvania, about the scholarly progress of a young Syrian boy he was sponsoring. ${ }^{18}$

Missionary humanitarians' diaries demonstrate a genuine zeal. One example is that of Charlotte Allen Ward, the wife of Edwin St John Ward, a missionary doctor first sent to the region by the American Board of Commissioners for Foreign Missions. By 1920, Edwin was a professor of surgery at the AUB as well as a Red Cross doctor. Charlotte's correspondence with family members living in Springfield Massachusetts demonstrates evident human empathy for those under her care. In May 1916 she wrote warmly of "Aigule Kalfian ... an Armenian girl from the Adana region" who had co-starred in a school play. ${ }^{19}$

Alongside individual organizations' humanitarian activity, a broader public campaign for humanitarian aid was launched during World War I. ${ }^{20}$ In 1915, the American Committee on Armenian Atrocities organized public fundraising events, such as a mass meeting at the Century Theatre in New York where the speakers included James L. Barton, the chairman of the Committee, and Rabbi Stephen Wise. The Committee had reportedly gained extensive publicity in the New York press. ${ }^{21}$ That year, Near East Relief (NER), was founded in the city; it

16 Mabel A. Elliot, American National Red Cross Disaster Services, 1881-1918 (Washington D.C.: American National Red Cross, 1950).

17 Daniel Oliver, Friends' Foreign Mission Association London, to Thomas and Ethel Potts (August 13, 1920), The Daniel And Emily Oliver Orphanage Collection 1134 (Haverford College Archives, Haverford, PA).

18 Daniel Oliver, to Herbert Welsh, Westtown Penn (June 13, 1914), Herbert Welch Collection 702, Series 2 Box 71 (Historical Society of Philadelphia, Philadelphia, PA).

19 Charlotte Allen Ward, Springfield, to her family (May 30, 1916), Ward Papers MS 0595, Series B, Box 4 (Mount Holyoke College Archives, South Hadley, MA).

20 Watenpaugh, Bread From Stones, 57-9o.

21 Samuel T. Dutton, NER Secretary, New York, to William W. Rockwell, Professor, Colombia 
was initially known as the American Committee for Armenian and Syrian Relief (ACASR) and the American Committee for Relief in the Near East (ACRNE).

In post-World War I Aleppo, the Near East Relief Foundation managed a school catering to 360 Armenian refugees. ${ }^{22}$ Near East Relief's scope provided it with an unprecedented capacity to respond humanely and rapidly to the wartime disasters. The Foundation's response to the 1922 Cilician crisis, when thousands of Greeks, Armenians, and Syrians had to flee as Turkey consolidated itself, was described in its report to Congress as an: "equally important, though less extensive relief service ... forced upon us".23

In 1922 the director of National Armenian Union (NAU) praised NER's efforts in a letter to its Middle East director Harold B. McAfee. He wrote of how the organization had saved "orphans and refugees from perishing in the Syrian deserts. While all other sources of relief have for some time past been closed to us, the Armenians will always remember with deepest gratitude the work of the Near East Relief ... without which the remnant of the Armenian people in those countries would certainly have perished". ${ }^{24}$

The NAU nevertheless warned that NER's planned departure from Aleppo would remove some 400 jobs that its factories provided as well as a school for refugee boys with 360 pupils. ${ }^{25}$ Budgetary pressures became increasingly evident over the early 1920 s as it struggled to cope with reduced income given that the World War spirit of mutual assistance dissipated. For instance, the considerable funds raised for NE R's nationally coordinated "Golden Rule" Sunday, which organized local activities and clothes-gathering in December 1923, were actually used to reduce operational deficits. ${ }^{26}$

College (October 18, 1915), Near East Relief Committee Records MrL2, Box 1 (Colombia University Burke Library, New York, NY).

Secretary \& Vice-President of Armenian National Union to Howard B. McAfee, Director of Near East Relief in Syria (February 23, 1922), microfilm: Microscopy 722, Roll 14, Records of the Department of State Relating to the Internal Affairs of Asia, 1910-1929, RG 59, Syria 89o.d, National Archives and Records Administration (hereafter NARA), College Park, MD.

23 Charles V. Vickery, Near East Relief: A Review for 1922 (Annual Report to Congress) (New York: Near East Relief, 1923).

24 Dr A. Djebedjian, Secretary of Armenian National Union (ANU), and Gabriel Cassarian, Vice-President ANU, to Howard B. Mcafee, Director NER Middle East (February 23, 1922), Microscopy 722, Roll 14, Records of the Department of State Relating to the Internal Affairs of Asia, 1910-1929, NARA.

25 Dr A. Djebedjian and Gabriel Cassarian (February 23, 1922), Microscopy 722, Roll 14 Records of the Department of State Relating to the Internal Affairs of Asia, 1910-1929, NARA.

26 Near East Relief, Report of International Golden Rule Sunday Observance (New York: Near East Relief, 1926). 
In May 1924 the Beiruti newspaper Al-Lubnān reported that NER was removing 1000 orphans from its boarding houses as a cost-cutting measure. Al-Lubnān called on Lebanese "men of will" to take the initiative in responding to this funding shortfall and to solve a problem that was testing the "dignity and authority of the nation". ${ }^{27}$ On July 1, 1926, the U.s. Congress passed an Act to "relieve" Near East Relief of its outstanding debts.

Despite budgetary pressures, NER remained the most significant American organization in the region. It secured $\$ 13$ million from U.s. government agencies, the U.s. Grain Corporation and the American Relief Administration and gathered clothing, commodities, and medicine from private donors. Among such donors were emigrant Syro-Lebanese (also known as Mahjaris) sending supplies to their compatriots. For instance, in 1919 an ACASR warehouse supervisor Hana Sabogg, the secretary of the Syrian Mount Lebanon Ladies Relief Society in Boston, for multiple shipments of provisions sent to Syria via the U.s. Navy. ${ }^{28}$

Between 1915 and 1922, NER had thus raised $\$ 84$ million of aid. ${ }^{29}$ To give a sense of the scope of this genuine humanitarian impulse, in May 1921 Colonies Secretary Winston Churchill estimated Britain's yearly budget for military, humanitarian, and other spending in the Middle East at around $£_{30}$ million (\$132 million). ${ }^{30}$ A summary of NER activities in 1926 noted that it operated in three regions: Armenia, the Near East, and Greece and Istanbul. It ran 93 industrial centres, 82 hospitals, and clinics with 6 o doctors and 142 nurses. It helped an overall of 6o,o92 children, of which 8183 were in Syria and Palestine. 380 boys and 300 girls had graduated from NER industrial shops and were supporting themselves independently. ${ }^{31}$

NER dwarfed the longer established Red Cross and Young Men's Christian Association (YMCA). YMCA and NER were jointly supported by funding from the Presbyterian Church's American Board of Missions, though the former had smaller operations. YMCA's relief work was done throughout the Near East,

27 State of Greater Lebanon, Press Service, "Revue de la presse de Beyrouth des 11 \& 12 Mai," (May 12, 1924), Fonds Beyrouth, Cabinet Politique, Series 1SL/v, Box 1682 (Ministère des Affaires Étrangères-Centre des Archives Diplomatiques (hereafter CADN), Nantes).

28 Fred H. Houseman, New York, to Hana Sabogg, Boston (August 12, 1919), Lebanese Syrian Ladies' Aid Society (Boston, MA) records 1917-2005, box 3 (Harvard University Schlesinger Women's Library, Boston, MA).

29 In 2014 values.

30 "Conclusions of a Meeting of the Cabinet Held at 1o, Downing Street, s.w., on Tuesday, 31st May, 1921, at 11.30 a.m." (May 31, 1921), САB/23/25, The National Archives (hereafter TNA), Kew.

31 Near East Relief, Report of International Golden Rule Sunday Observance. 
from Turkey, through Armenia to Palestine. Cilician activities were attached to its Turkey mission. The YMCA's Syria mission had four stations at Beirut, Sidon, Tripoli. Funding problems were evident, though attempts were made to maintain coverage in Syria "proper". At one of its meetings, it was agreed that since the YMCA at Aleppo "had been and should continue to be a helpful adjunct ... the ... clerk of the Syria mission [should] send ... [a] telegram [to] ... YMCA Constantinople [and the] American Presbyterian Mission ... [to] unanimously urge continuance of Aleppo YMCA". 32

In Adana, then still part of French-controlled Cilicia before Turkish reconsolidation, the Young Women's Christian Association (YWCA) also installed itself in April 1920 and recruited local upper-class ladies and girls of Greek and Armenian descent. It provided physical education and English lessons and provided food relief to local women employed by an English Lord Mayor's Fund's factory through a soup kitchen. ${ }^{33}$ The American Red Cross was equally active. On June 14, 1922, it transported 400 Armenian girls and women to Aleppo to save them from troubles in Cilicia. ${ }^{34}$ By March 1929, the U.s. Consul in Beirut noted that the American Red Cross had contributed \$12.5 million channeled through Geneva to support Armenians in Syria. ${ }^{35}$

\section{Orientalism and "Machine Age Humanitarianism"}

Scholars have noted the deep Orientalism at the heart of Western public and official engagement with the Middle East. ${ }^{36}$ Examining American humanitarian activity nevertheless paints a more complex picture. There certainly were religiously-motivated essentialisms of the objects of humanitarian action. Yet there were also efforts seeking to humanize those in need. Finally, the impact

32 "Minutes of the General Winter Meeting of the Syrian Mission, December 7th to 16th 1920," (January 1921), Record Group, Box 1 (Philadelphia: Presbyterian Historical Society Archives).

33 Administrative Services Cilicie, Délégué Administratif, "Etude d' ensemble sur les œuvres d'assistance scolaire et de tous autre ordres fonctionnant en Cilicie," (October 31, 1920), Fonds Beyrouth, Cabinet Politique, Series 1SL/v, Box 1682 (CADN).

34 British Liaison Officer to the French Army in the Levant, Beirut, to General Staff Intelligence, Cairo (July 27, 1922), FO684/1 (TNA).

35 George L. Brandt, U.s. Consul Beirut to Secretary of State, Washington (March 28, 1929), microfilm Reel of 21, Confidential U.s. Diplomatic Post Records: The Middle East (Beirut, NARA).

36 Edward Said, Orientalism (London: Penguin, 2006); Watenpaugh, Bread from Stones, 7 . 
of organizational bureaucratization in a "Machine Age" further deepened tensions between the humanitarian impulse and a modern humanitarian bureaucracy penetrated by orientalist conceptions.

Some American humanitarians in the region reminded their donors and participants that theirs was a fundamentally humane work. In the words of Edward Raffety, chairman of NER's national Sunday school advisory committee: "Near East Relief, in its first humanitarian impulse ... serves a divine mission ... it has humanized the subject; it helped to make Syria and Palestine ... Armenia ... real ... the fact that Sunday school children of every denomination in the United States have contributed toward feeding, clothing, sheltering and education thousands of helpless children overseas has proved the efficacy of this united effort". 37

Despite Raffety's optimism, it has been noted that most aid went to crisishit and dislocated Assyrians, Greeks, and Armenians. ${ }^{38}$ It is telling that no effort seems to have been made to interact with the aforementioned, wellestablished, Muslim charitable institutions. ${ }^{39}$ Indeed, in 1924, the Sunni Beiruti newspaper Al-Kashkül suggested that not one of NER's orphanages hosted a Muslim child. It alleged that all of them were dedicated to converting Armenians to Protestantism. In addition, Al-Kashkül complained that this situation held despite most of NER's funding was in fact coming from mahjar donations intended to aid all Syrians and Lebanese populations, not just Christians. It asked NER to provide a public account of its sources of funding. ${ }^{40}$

NER posters (Figures 8.1 and 8.2) demonstrate typical stereotyping of beneficiaries, presumably to secure Americans' donations. This approach was not simply visual. A committee member of Near East Relief wrote to a New York donor asking for money for a 15-year-old Lebanese girl. He described the girl's harsh upbringing during the Ottoman period in simultaneously humane and subjectivizing terms:

We called her 'Bedi Tick' because she lisped this Arabic phrase 'I want a penny' to us. A lovely face, pinched with hunger, but bravely trying to

37 W. Edward Raffety, "Children and the New World," The New Near East 8, no. 12 (December 1923).

38 Watenpaugh, "The League of Nations."

39 Beth Baron, "Orphans and Abandoned Children in Modern Egypt," in Interpreting Welfare and Relief in the Middle East, eds. Nefissa Naguib and Inger Marie Okkenhaug (Leiden: Brill, 2008).

40 State of Greater Lebanon, Press Service, "Revue de la presse de Beyrouth du 19 Décembre," (December 19, 1924), Fonds Beyrouth, Cabinet Politique, Series 1SL/v, Box 1682 (CADN). 


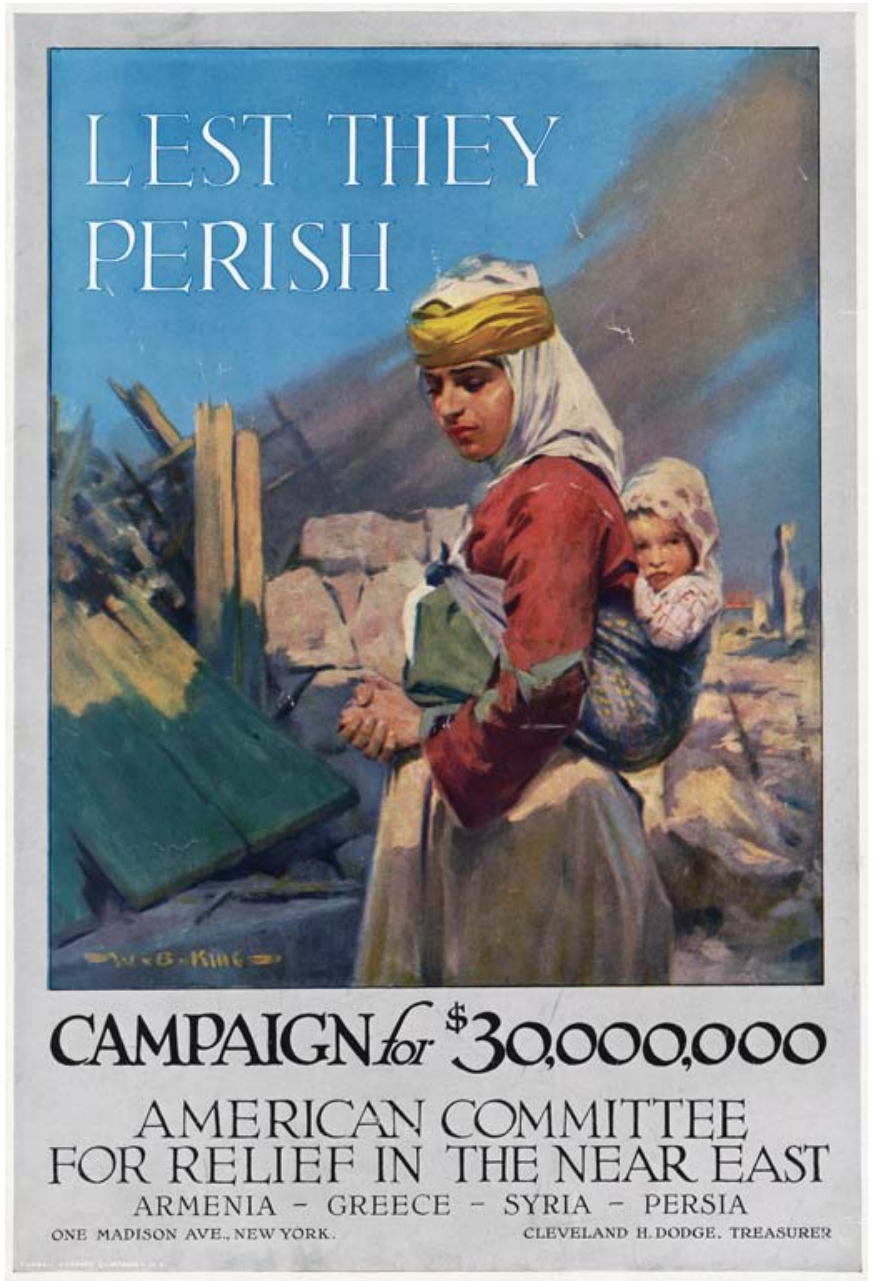

FIGURE 8.1 A 1917 ACRNE poster depicting the compassionate, if Orientalist, efforts of American humanitarianism in the Middle East. Library of Congress collection, https://lccn .loc.gov/2002711981

smile ... That was in Beirut in 1916 ... [she] only lived because an American hid her and fed her at the risk of imprisonment for what the Turks called 'treason' or 'American propaganda'. ${ }^{41}$

41 H.S. Meredith, Committee for Near East Relief, New York, to Talcott Williams, New York, (September 13, 1927), Near East Relief Committee Records M RL2, Box 7 (New York: Colombia University Burke Library (hereafter CU-B)). 


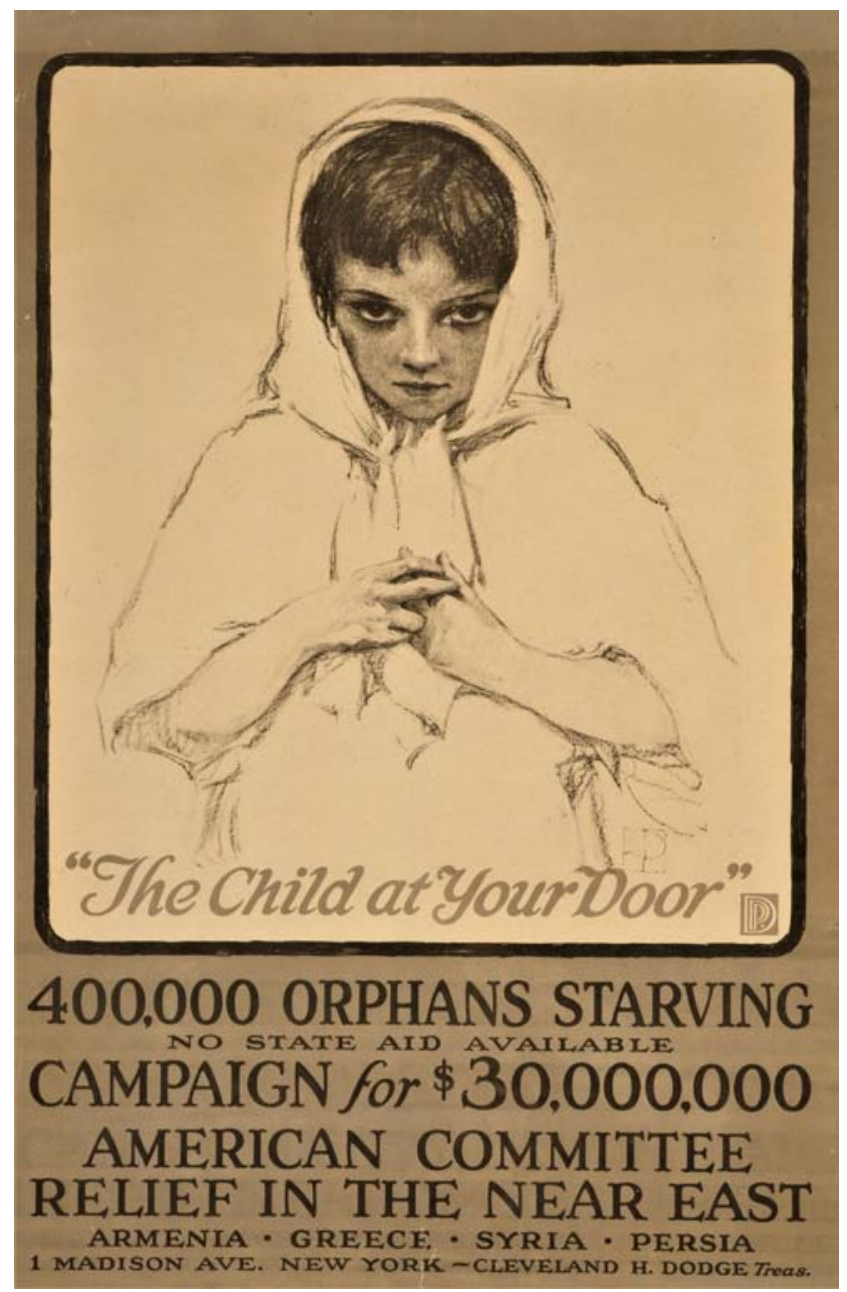

FIGURE 8.2 Another 1917 ACRNE poster asking for compassionate donations from American citizens. Library of Congress collection, https://lccn.loc.gov/2002719422

Some humanitarian institutions clearly sought to convert locals as Al-Kash$k \bar{u} l$ had warned. In northern Syria, one report from the Presbyterian Board of Missions noted the education being provided by the Syrian Protestant Institute in Homs and the Tripoli Boys School in Tripoli. The Tripoli Girls' school was highly rated by locals, according to the report, with its alumni becoming "teachers in the village schools, wives of preachers and mothers of boys who have become teachers and preachers". ${ }^{42}$

42 "Minutes of the General Winter Meeting of the Syrian Mission-December 7th to 16th 
It suggested that Muslims had become increasingly interested in sending their girls to the school which was ideal because it would allow the school to fulfill "her twofold function so to train the Christian girls of northern Syria ... and to lead the Moslem girls of Tripoli out of ignorance and the darkness of superstition into the light". ${ }^{43}$ Nevertheless, other American institutions such as the AUB were among the first in the region to institute non-denominational schooling.

In 1925, an American school for girls was founded in Damascus offering Arabic, French, and English instruction. Classical Arabic was also taught through a special arrangement with local Sheikhs. A great majority of students were Muslim with some Jews and Christians also in attendance. ${ }^{44}$ When told that the school, while admirable, would "only be a drop in the bucket" with regard to the need for educating Syrians, the school's director, Christine Adamson Essenberg, retorted that her school would "not be the only drop ... others will add theirs until the bucket is overflowingly full".45

A profile of Essenberg in the Pittsburg-Post Gazette painted her work in heavily Orientalist imagery, yet Essenberg herself clearly expressed her respect for the local culture. She explained that: "it was never my purpose to endeavor to 'westernize' these girls ... my primary objective ... is to educate".46

Alongside this ambiguity, U.s. humanitarian institutions introduced a capitalist-influenced bureaucratization. This approach had itself been preceded by American pragmatist thought which influenced American religious philanthropy during the post-Civil War domestic recovery. ${ }^{47}$ Near East Relief embraced the "science of management" zeitgeist. As a large organization, it undertook careful monitoring, auditing, and outsourcing of its operations. This element of "sovereignty" over humanitarian "subjects" did not necessarily contravene existing Orientalist imagery.

1920," (January 1921), Record Group 9o, Box 1 (Philadelphia, PA: Presbyterian Historical Society Archives).

43 Ibid.

44 Committee of Correspondence Records (CoC), Series v: Correspondents and Fieldwork, Box 39 (Northampton, MA: Sophia Smith Collection (sSC)).

45 Ibid.

46 Anne Weiss, "Education Removes Veil of Darkness for Women," The Pittsburgh Press, February $19,1934,22$.

47 Michael Barnett, "Faith in the Machine? Humanitarianism in an Age of Bureaucratization," in Sacred Aid: Faith and Humanitarianism, eds. Michael Barnett and Janice Gross Stein (Oxford: Oxford University Press, 2012). 
However, it did introduce a new element of "managerial", as opposed to classic European, "romantic", oversight. As Alfred McCoy has shown, the American experience in policing the Philippines had depended on a vast surveillance regime using technological advances such as Alexander Graham Bell's telephone and Charles Flint's punch-cards. This distinguished American foreign rule from contemporary British and French colonial reliance on culturally specific and in-depth "romantic" Orientalist knowledge. ${ }^{48}$

American humanitarians in the Middle East were aware of their technocratic approach. One article in NER's bulletin cheerfully explained that:

America has brought a new spirit to the Near Eastern countries ... our intervention in the Near East has been unofficial and mainly humanitarian in character ... the American people have been working, not for Mesopotamia's oil fields, not for the Baghdad railway ... but simply and purely for humanity ... there has come out of the West ... a force that acts from other motives than political selfishness ... It is the most modern thing ... we have brought to these age-old lands the shock of the machine age, the age of organization. ${ }^{49}$

Chaired by corporate executives and armed with the slogan "hunger knows no armistice" (figure 8.3), Near East Relief was a modern organization with certified accountants and savings in operational expenses. NER general secretary Charles Vickery wrote to Talcott Williams in New York City to secure funds from the other charities such as the Carnegie Foundation. ${ }^{50}$

An article in NER's magazine explained: "an important reorganization of our work ... for the purpose of securing greater economy and efficiency through consolidation. The offices, garages, warehouse, supply base, industrial department, personal service, and shipping operations were all concentrated into one general headquarters ... on the Bosphorus. This ... resulted in a saving of at least 25 percent in cost of operation".51

Despite this organizational and managerial directedness, NER also enabled the employment of those under its care, encouraging an element of autonom-

48 Alfred W. McCoy, Policing America's Empire: The United States, The Philippines, and the Rise of the Surveillance State (Madison, Wr: Wisconsin University Press, 2009).

49 "Machine Age Humanitarianism," extract from the 1923 report of the Overseas Commission, The New Near East 8, no. 12 (December 1923).

50 Charles Vickery, Secretary of Near East Relief, to Talcott Williams, New York (March 3, 1920), Near East Relief Committee Records MRL2, Box 7 (New York, NY: CU-B).

$5^{1} \quad$ Vickery, Near East Relief. 


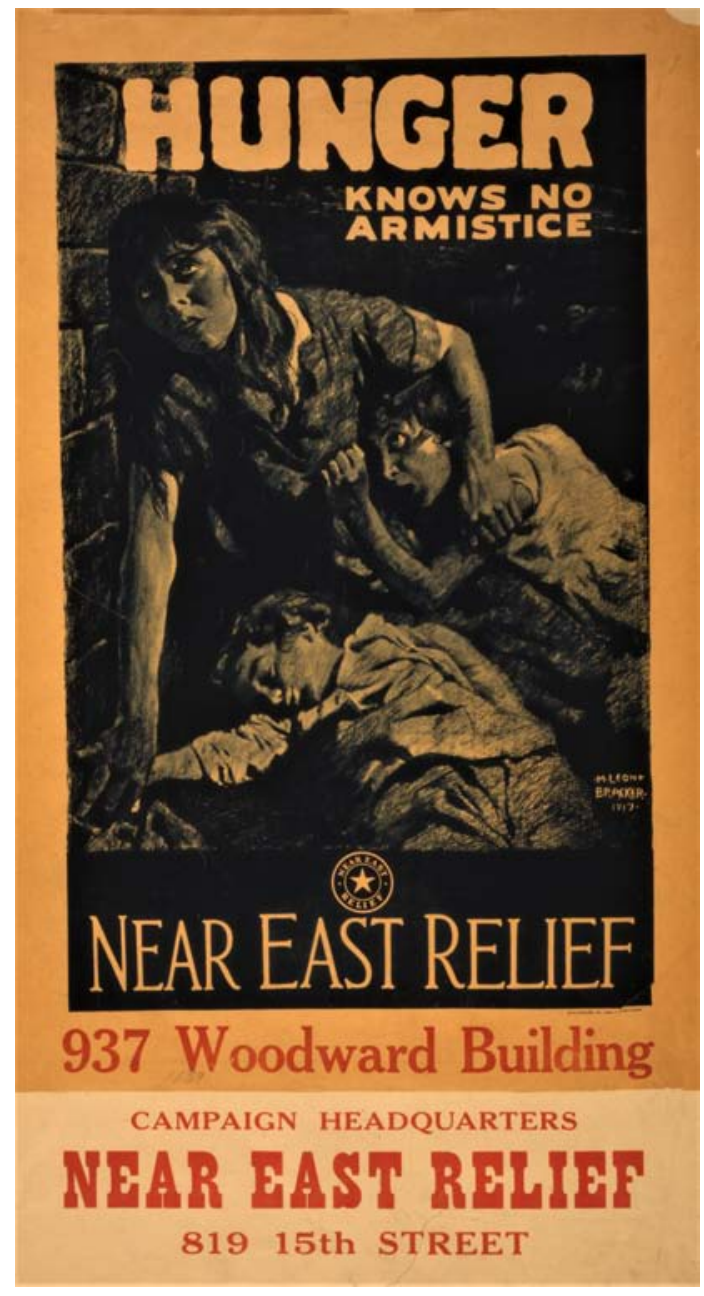

FIGURE 8.3

A later poster dating from 1919 and printed by ACRNE's successor organization; Near East Relief (NER). Library of Congress collection, https://lccn.loc.gov/ 2002708879

ous development. ${ }^{52}$ In NER's magazine, the New Near East, Charles Vickery described the 89,000 Armenian refugees located in Aleppo in 1922. These refugees were:

Industrious, ready for any kind of service if work is available but, under existing economic and political conditions, they are helpless ... they are among the most thrifty people in the world. Despite the fact that the

52 Davide Rodogno, "Beyond Relief: A Sketch of the Near East Relief's Humanitarian Operations, 1918-1929," Monde(s): Histoire, Espace, Relations 2, no. 6 (2014): 45-64. 
refugees are chiefly women, old men and children, they quickly regain self-support if given the opportunity. Of the 27,00o that reached Beirut, Syria, in 1922, and were established in refugee camps, only 600 are now receiving aid from the Relief Committee. ${ }^{53}$

In rhetoric and in practice, organizational coherence did not reduce empathy for the unfortunate. In July 1920, the New Jersey newspaper Morning Call reported that thanks to Near East, "Armenians took over the maintenance of relief stations, hospitals and orphanages". ${ }^{44}$ NER's journal also advertised a small shop in New York City, the Flambeau Shop, which advertised goods made by Near East Industries and sold customers the: "perfect Christmas gift which combined 'individuality, utility and charm'". ${ }^{55}$ Near East Industries was an NER project intended to create a distribution centre for refugee-made merchandise. In 1922, it sold $\$ 23,000$ worth of goods. ${ }^{56}$

Despite NER's attempts at being a scientifically managed organization and its aims to work with dispassionate interest, the political dimension of relief work in a strategic region undergoing European state-building was inexorable. The League, in practice if not in theory, allowed for a continuation of colonial power according to imperial interests. Susan Pedersen has summarized the League's Mandates Commission as being "a discursive arena and not an administrative system". ${ }^{57}$ It is precisely this "discursive arena" that enabled powers other than the mandatory to establish a foothold in the territories; ultimately providing an alternative to colonial designs.

Aside from Soviet Russia, the United States was prominent in undertaking this task. It built on its previous engagement in Ottoman times by pursuing a so-called "open door" policy. A us-French deal was reached in July 1924, reaffirming Americans' special legal privileges on the same basis as those afforded to League of Nations member nations' citizens. ${ }^{58}$ According to Keith Waten-

\footnotetext{
53 Vickery, Near East Relief, 27.

54 Erla Rodakiewicz, Foreign Born: A Bulletin of American Service (New York, NY: Young Women's Christian Association USA, 1920), 54.

55 "Machine Age Humanitarianism."

56 Vickery, Near East Relief, 32.

57 Susan Pedersen, "The Meaning of the Mandates System: An Argument," Geschichte und Gesellschaft 32, no. 4 (2006): 56o-582.

$5^{8}$ Governments of the United States and France, "Convention between the United States
} 
paugh the lack of a direct American mandate over Armenia had demonstrated "the real limits of American power in the early $1920{ }^{\circ}$ ". ${ }^{59}$ Yet this could instead be read as a deliberate U.s. sidestepping of involving itself in costly and ugly Middle East imbroglios; as Iraq (rebellion in 1920), Syria (rebellion in 1925) and Palestine (rebellion in 1936) all proved to be. American strategic planners were more directly concerned with the economic domination of their hemisphere and the Pacific.

Colonial rivalries in the "Old World" could thus be balanced one against the other while America entrenched its economic capacity and dominance. One contemporary lecture given by the future president, young Wilsonian and then vice-presidential candidate, Franklin D. Roosevelt, outlined this long-term strategic view. American circumvention of League and Mandates involvement did not mean it did not have a weak voice in this forum. Roosevelt believed that: "President Wilson slipped one over on Lloyd George when he was in Paris, because while England and her colonies are apparently getting six votes to our one, the United States has a lot more ... For instance, does anybody suppose that the votes of Cuba, Haiti, San Domingo, Panama, Nicaragua and of the other Central American states [in the League] would be cast differently from the vote of the United States?"60

It is true that certain policy makers had advocated a full American mandate over Armenia; many of them had indeed been sponsors of the aforementioned humanitarian efforts. William H. Hall, who had led one of President Wilson's Inquiry committees prior to the rise of Republican Turkey, had recommended that a Western power without colonial interests, with America's experience in the Philippines as a model, should hold a direct mandate over the Turkish parts of the dismembered Ottoman Empire. ${ }^{61}$ Another Inquiry member, Columbia College professor Paul Monroe, explained the political capital to be gained from American humanitarian and educational engagement in the Levant. He wrote: "of all the foreign educational systems in the Empire, the American undoubtedly holds first place ... The schools should be closely correlated with

and France Respecting Rights in Syria and the Lebanon," The American Journal of International Law 19, no. 1 (1925): 1-5.

59 Keith David Watenpaugh, "Between Communal Survival and National Aspiration," in The Routledge Handbook of the History of the Middle East Mandates, eds. Cyrus Schayegh and Andrew Arsan (Abingdon: Routledge, 2015), 41.

6o "Speeches of FDR: Drafts and Reading Copies. Speech at Milwaukee" (August 12, 1920), Arthur M. Schlesinger Papers, Box 448 (New York Public Library Archives \& Manuscripts Division Public, Stephen A. Schwarzman Building).

61 Joseph L. Grabill, Protestant Diplomacy and the Near East: Missionary Influence on American Policy, 1810-1927 (Minneapolis, MN: University of Minnesota Press, 1971), 125. 
the community ... in all of these respects the work of the Philippine school system would serve as a model". ${ }^{62}$

Humanitarian executives and institutions were equally vocal in expressing hopes for greater American political involvement in the region. NER executive James L. Barton overtly encouraged an American mandate over Armenia. He wrote: "there are many who would shrink from such an undertaking because of the [difficult] experience which the French are now undergoing in attempting to pacify even a small section of Lesser Armenia [Cilicia]. There is every reason for believing that America's experience would be wholly different from that of the French".63

NER'S wartime predecessor, the ACASR, had called for the prohibition of European spheres of influence in order to ensure that the natural "riches should be reserved for the enrichment and the development by the people to whom they rightfully belong"; an echo of the findings of the U.s.' King-Crane Commission. ${ }^{64}$

Writing in the The New Near East, Reverend Samuel Craver summarized the tensions between American visions for intervention in the region. He wrote that:

The humanitarian work ... is a symbol ... of America at its best. There are many Americas. A political America, which has not yet played its full part in preventing war and building up international co-operation. An economic America which has its eyes riveted on trade advantages ... But ... also an idealistic, a humanitarian, a religious America ... finding magnificent expression in its work of mercy in the Near East ... The boys and girls who are our wards in these orphanages are an important part of the coming generation ... in the higher life of this chaotic area of the world. ${ }^{65}$

62 Paul Monroe, "The Ottoman Empire: Education," [n.d.], 42, Ms8 The Inquiry Papers, Series III, Box 23 (Yale Manuscripts and Archives New Haven (hereafter YUMA)), Jonathan Zimmerman has noted the direct links between missionary schooling in the Philippines and those in Syria. Jonathan Zimmerman, Innocents Abroad: American Teachers in the American Century (Cambridge, MA: Harvard University Press, 2008), 56.

63 James L. Barton, "Has America Responsibility for Protecting Armenia?" (n.d.), Near East Relief Committee Records MrL2, Box 7, CU-B.

64 American Committee for Syrian and Armenian Relief, Recommendations for Political Reconstruction in the Turkish Empire (November 1918), India Office Records, Series L/PS/1, Box 158 (London, British Library).

65 Reverend Samuel McCrea Caver, General Secretary of Federal council of Churches of Christ in America, "America and the Golden Rule," The New Near East VIII, XII (December 1923). 
The porosity between official and non-official U.s. planning, policy, and activity was suspiciously viewed by local administrations, leading to further politicization of humanitarianism. In 1916, the political director of the Ottoman police had contacted American diplomats to express concerns over Rockefeller Foundation worker Edward R. Stoever. Stoever was undertaking his Rockefeller work from within the American embassy. ${ }^{66}$

During the post-World War interregnum, prior to the formal establishment of the mandate in 1920, a watchlist of suspects circulated by French military administrators included a local Beiruti, Chehadé Chehadé, described as an agent of the American Red Cross. ${ }^{67}$ This was likely because Chehadé had accompanied a British Major to greet the King-Crane commission's arrival in the Lebanese town of Zahlé. ${ }^{8}$ The fears were not unfounded. In 1922, the British liaison officer to the French army in Beirut reported that an NER worker had been a British informant, passing information from correspondence going through NER's Urfa depot. ${ }^{69}$

NER's operation in Cilicia also raised French suspicions. One French report suggested that NER's chief in Istanbul, Dr William Nesbitt Chambers, had been rude when discussing relief efforts with the chief of the Service des Rapatriements et de l'Assistance (Repatriation and Assistance Service). A competition in this region had developed between American and French relief providers, meaning that some of those in need had been helped twice over while others went unaided. Another flare-up occurred over the fate of the material left by German missionary sisters at Bahçe after their expulsion by the French. Their orphanage, its buildings, and goods were seized by French Colonel Edouard

66 Cornelius van Engert, Diary entry for Thursday (October 19, 1916), GTM.800320 Richard T. Crane Papers, Box 1 (Washington D.C.: Georgetown University Lauinger Library); Rockefeller Foundation, The Rockefeller Foundation Annual Report (New York: Rockefeller, 1916): 329-330.

67 "Liste des personnes suspectes (Syriens)," (n.d.) Fonds Beyrouth, Cabinet Politique, Series $1 \mathrm{SL} / \mathrm{V}$, Box 982 .

68 Administration du Liban, délégué de Zahlé, "Compte Rendu du Lieutenant Leymarin," (July 12, 1919), Fonds Beyrouth, Cabinet Politique, Series 1SL/v, Box 2372. The French High Commission's delegate in Zahlé intercepted the King-Crane convoy after an informant reported that Chehadé was planning on having them stay at his house. Chehadé had told the King-Crane convoy that the city was out of hotel rooms. Delegate Leymarin stopped the American Commission's cars and told them that rooms were awaiting them at the city's Hotel Kadri.

69 British Liaison Officer to the French Army in the Levant, Beirut, to General Staff Intelligence, Cairo (May 25, 1922), FO684/1 (TNA). 
Bremond, who oversaw the region, though it had eventually been released to NER's Dr Chambers. ${ }^{70}$ On another occasion, the region's economic bureau refused NER requests for authorization to chop wood and import peas though it did allow it to purchase dry wood.

Considering these tensions, Colonel Bremond wrote a report in which he explained that, though the Americans did not have a consul in Cilicia:

Under the cover of welfare or charity, they are undertaking an extremely active propaganda ... which has become clearly anti-French ... the work of welfare has become something more than a pure act of charity. It is a great proportion of the population that needs material aid ... [therefore] the one who provides welfare naturally exercises an influence ... of a political character. ${ }^{71}$

In a surrealistically childish manner, Bremond thought that the Americans were seeking to "steal" "French" orphans. After a YMCA orphanage offered summer courses, he claimed that the Americans were seeking to permanently incorporate the children. Bremond proudly proclaimed such an attempt to "tempt" the children had been "fought off" by improving local French educational facilities. He reserved praise for Mrs Gagneux, the wife of a French lieutenant and director of the Armenian orphanage in Adana, who had managed to retain her children by distributing toys which had "brought a delirious joy".

In contrast to Bremond's juvenile tone, a letter from the head of the YMCA, Olin Lee, to one of his subordinates, Lieutenant Gagneux, conveyed an entirely different tone. Lee thanked Gagneux for his support of the American summer school and provision of French teachers. ${ }^{72}$ In his reply, Gagneux told Olin Lee that "in a country like Cilicia where everything remains to be done for the education of the populations, the YMCA has a big role to play, you can be sure of the most complete support by the French authorities.".73

70 Armée du Levant, Délégué Administratif en Cilicie, "Note sur les relations des autorités françaises avec l'A.C.R.N.E. en Cilicie," (November 8, 1920), Fonds Beyrouth, Cabinet Politique, Series isL/v, Box 1564 (CADN).

71 Colonel Bremond, Chef du Contrôle Administratif de Cilicie, "Rapport sur les empiètements des Américains en particulier au sujet des orphelins" (July 16, 1920), Fonds Beyrouth, Cabinet Politique, Series isL/v, Box 1564 (CADN).

72 Olin P. Lee, General Secretary of the YMCA (Near East), to Lieutenant Gagneux, Chef des Services de Rapatriement et de l'Assistance, Adana (November 2, 1920), Fonds Beyrouth, Cabinet Politique, Series 1SL/v, Box 1564 .

73 Lieutenant Gagneux to Olin P. Lee, General Secretary of YMCA Adana (November 8, 1920), Fonds Beyrouth, Cabinet Politique, Series 1SL/v, Box 1564 (CADN). 
In fact, French funding for welfare and humanitarian aid lacked organization throughout the early years. In his wartime diary, State Department intelligence officer and former Standard Oil representative in Palestine Captain William Yale noted the absence of French relief. The NER council had "tried to discover a similar organization in France with which they could cooperate but had been unable to". ${ }^{74}$ During Christmas 1918, French foreign office officials discussed "assuring the relief of French expats in oriental countries" who needed luxurious commodities such as coffee and sugar for the holidays; while a famine was ravaging the Levant. ${ }^{75}$

Despite these deficiencies, it should be noted that French officials did make efforts to increase humanitarian support as they secured their Levantine territories. French support for orphans grew from two orphanages housing 500 children before World War I to caring for over 9,0oo orphans 1919. Around 1,000 women who were out of work and without housing were put in workhouses. Similar statistics are evident for the years from 1920 onward. Yet consulting the French mandate's budget archives gives some sense of the limited scale of the French humanitarian effort; a duty that was concomitant with League of Nations mandatory welfare state responsibilities.

In 1921, out of a 48.7 million Francs budget for Lebanon, all welfare spending (in the broadest sense to include education, healthcare, and so on) amounted to 4.2 million, less than $10 \%$. The restive interior Syrian states such as Aleppo, which required greater security spending, demonstrated a lower ratio of welfare spending. In fact, statistics give a misleading picture since welfare was often blurred with security. For instance, the military intelligence officer in charge of the district of Al-Hasakah was also organizing food distribution. ${ }^{76}$

Despite French suspicions of "Anglo-Saxon" interference, the presence of "Machine Age" American humanitarians provided materially, if not politically, welcome support for French administrators' efforts. A report by British Consul in Aleppo Norman Mayers outlined how French administrators maintained Ottoman-era privileges for foreign institutions, thus allowing British and American institutions to participate in educational and humanitarian activities. He wrote that:

74 William Yale Diary (September 19, 1917), Ms658 William Yale Papers, Box 2, YUmA.

75 Under Secretary of State for Relief Works to Minister of Foreign Affairs (December 9, 1918), Series E-Levant, Box 59 (Ministère des Affaires Étrangères-Centre des Archives Diplomatiques, La Courneuve).

76 Service Des Renseignments, "Rapport Trimestriel 4ème Trimestre 1924: Situation Des Refugies," (January 1925) Fonds Beyrouth, Cabinet Politique, Series 1SL/v, Box 1843 (CADN). 
The French authorities show themselves very reasonable in ... governing privileges ... the only change ... is not the result of any cutting down of immunities, but ... the abolition of the capitulations ... [which] gave many privileges [to religious and charitable organizations] ... the presence of whom ... represented, perhaps, a net saving to the [Ottoman] exchequer [i.e. public finances]. ${ }^{77}$

A report on Armenian refugees in Aleppo from the High Commissioner's delegate to the Aleppo State in 1923 is revealing. It outlines how refugee aid for Armenians in Aleppo was provided by a mix of American Near East Relief contributions, the High Commissioner's Aleppo delegate (76,ooo Francs) and a supplemental 6o,ooo Francs coming from the Syrian Federation (Syrian taxpayer-paid) budget. ${ }^{78}$ This French policy of continuing the Ottoman tradition of allowing non-political humanitarian activity to enable a "net-saving to the exchequer" was recognized by NER, which sought to avoid naively shouldering French governmental burdens.

On the ground, in Beirut, NER's director Harold B. McAfee informed his superiors that he would avoid American providing funds via French High Commissioner Robert De Caix because:

The French Government is insolvent ... any appropriation made for the ... Armenian refugees will all be absorbed in graft ... the Government is spending more on this enormous standing army ... than it will ever get in Syria in taxes ... this abominable official class that is in control here is enough to rejoice the Devil. ${ }^{79}$

\section{5}

Conclusion

American humanitarianism made a significant, and political, intervention in the early 2oth century Levant. On the one hand, United States institutions and individuals demonstrated zeal in their humanitarian impulse which had

\footnotetext{
77 Norman Mayers, British Consul Aleppo, "Report on the Fiscal Immunities and Privileges in Syria of Patriarchs, Heads of Religious Bodies, Institutions, and Charitable or Other Organizations Deriving Thereof," (November 28, 1925) FO861/82/1358 (TNA).

78 Délégué-adjoint du Haut-Commissaire, Président de la Commission, "Rapport," (March 3 , 1923) Fonds Beyrouth, Cabinet Politique, Series isL/v, Box 996 (CADN).

79 Harold B. McAfee to Charles Vickery (March 15, 1922), Microscopy 722, Roll 14, Records of the Department of State Relating to the Internal Affairs of Asia, 1910-1929, RG 59, Syria 89o.d, NARA.
} 
been established in the 19th century. In the 1920s, humanitarian outreach did continue to favour Christian minorities yet, despite Orientalist framing of the beneficiaries, there is little evidence of disdainful attitudes toward them. The response to World War I demonstrated an enthusiasm that combined with the managerial zeitgeist to produce what was self-consciously termed "Machine Age humanitarianism" by Near East Relief, the biggest of the U.s. operators.

Inevitably, the significant structure given to U.s.-Levant ties through humanitarian aid spilled into the political arena. U.s. officials and East Coast elites recognized the importance of this field for their growing influence in the region. French Mandatory authorities, who had taken over from the Ottomans after the World War, viewed such activity suspiciously, though they welcomed the income that enabled them to reduce their state-building obligations. Although the provision of healthcare has always been tied to symbolic power, the provision of state-directed social programs is particularly tied to the rise of the modern welfare state. ${ }^{80} \mathrm{By}$ assisting the French authorities in recovering from the devastation of the World War, the U.s. humanitarian agencies were simultaneously aiding locals while inadvertently impeding the development of a modern state system with relations to social groups.

\title{
Bibliography
}

\author{
Manuscripts and Archives \\ France \\ Centre des Archives Diplomatiques, Nantes (CADN). \\ Fonds Beyrouth, Cabinet Politique, Series 1SL/v. \\ Centre des Archives Diplomatiques, La Courneuve (CADL). \\ Series E-Levant.
}

\section{United Kingdom}

British Library, London (BL).

India Office Records, Series L/Ps/1.

The National Archives, Kew (TNA).

Cabinet Office, $\mathrm{CAB} / 23 / 25$.

Foreign Office, Fo684/1.

80 The marabouts (French), wandering spiritual healers, were local power-holders in North African rural areas. These murabitin (Arabic) also migrated to the Lebanese mountains. 


\section{United States}

Colombia University Burke Library, New York, NY. Near East Relief Committee Records (MRL2).

Georgetown University Lauinger Library, Washington D.C. GTM.8oo32o Richard T. Crane Papers.

Harvard University Schlesinger Women's Library, Boston, MA. Lebanese Syrian Ladies' Aid Society (Boston, Mass.) Records 1917-2005.

Haverford College Archives, Haverford. The Daniel And Emily Oliver Orphanage Collection (1134).

Historical Society of Philadelphia, Philadelphia. Herbert Welch Collection (702).

Mount Holyoke College Archives, South Hadley, MA. Ward Papers (MS 0595), Series B, Box 4.

National Archives and Records Administration, College Park MD (NARA).

Records of the Department of State Relating to the Internal Affairs of Asia, 19101929, RG 59, Syria 89o.d.

Confidential u.s. Diplomatic Post Records: The Middle East.

New York Public Library Archives \& Manuscripts Division, New York. Arthur M. Schlesinger Papers.

Presbyterian Historical Society Archives, Philadelphia. Record Group 90.

Sophia Smith Collection, Smith College Northampton MA.

Committee of Correspondence Records (CoC), Series v: Correspondents and Fieldwork.

Yale University Manuscripts and Archives Division, New Haven, CT (YUMA). Ms8 The Inquiry Papers. Ms658 William Yale Papers.

\section{Articles, Newspapers, and Books}

Anderson, Betty S. The American University of Beirut: Arab Nationalism \& Liberal Education. Austin, Tx: University of Texas Press, 2011.

Barnett, Michael, and Janice Gross Stein, eds. Sacred Aid: Faith and Humanitarianism. Oxford: Oxford University Press, 2012.

Barnett, Michael N. Empire of Humanity: A History of Humanitarianism. Ithaca, NY: Cornell University Press, 2013.

Robert Khouri, "Histoire De La Médecine Au Liban," Journal Médicale Libanais 58, no. 1 (2010): 28-44; Kwong-Leung Tang, Colonial State and Social Policy: Social Welfare Development in Hong Kong 1842-1997 (Lanham, MD: University Press of America, 1998). 
Baron, Beth. "Orphans and Abandoned Children in Modern Egypt." In Interpreting Welfare and Relief in the Middle East, edited by Nefissa Naguib and Inger Marie Okkenhaug (Leiden: Brill, 2008).

Benthall, Jonathan, and Jerome Bellion-Jourdan, eds. The Charitable Crescent: Politics of Aid in the Muslim World. London: I.B. Tauris, 2003.

Bonner, Michael, Mine Ener and Amy Singer, eds. Poverty and Charity in Middle Eastern Contexts. Albany, NY: sunY Press, 2003.

Caver, Samuel McCrea. "America and the Golden Rule." The New Near East 8, no. 12 (December 1923).

Daniel, Robert L. American Philanthropy in the Near East, 1820-196o. Athens, OH: Ohio University Press, 1970.

Elliot, Mabel A. American National Red Cross Disaster Services, 1881-1918. Washington D.C.: American National Red Cross, 1950.

Fleischmann, Ellen. "The Impact of American Protestant Missions in Lebanon on the Construction of Female Identity, c. 186o-1950." Islam and Christian-Muslim Relations 13, no. 4 (2002): 411-426.

Fleischmann, Ellen. "Evangelization or Education: American Protestant Missionaries, The American Board, and the Girls and Women of Syria (1830-1910)." In New Faith in Ancient Lands: Western Missions in the Middle East in the Nineteenth and Early Twentieth Centuries, edited by Heleen Murre-van den Berg, 263-28o. sсм 32. Leiden: Brill, 2006.

Fleischmann, Ellen. "Lost in Translation: Home Economics and the Sidon Girls' School of Lebanon, c. 1924-1932." Social Sciences and Missions 23, no. 1 (2010): 32-62.

Forsythe, David P. The Humanitarians: The International Committee of the Red Cross. Cambridge: Cambridge University Press, 2005.

Governments of the United States and France. "Convention between the United States and France Respecting Rights in Syria and the Lebanon." The American Journal of International Law 19, no. 1 (January 1925): 1-5.

Grabill, Joseph L. Protestant Diplomacy and the Near East: MissionaryInfluence on American Policy, 1810-1927. Minneapolis, MN: University of Minnesota Press, 1971.

Klingberg, Frank J. "The Evolution of the Humanitarian Spirit in Eighteenth Century England." The Pennsylvania Magazine of History and Biography 66, no. 3 (July 1942): 26o-278.

Krafess, Jamal. "The Influence of the Muslim Religion in Humanitarian Aid." International Review of the Red Cross 87, no. 858 (June 2005): 327-342.

Lindner, Christine B. "Negotiating The Field: American Protestant Missionaries in Ottoman Syria, 1823 To 186o." PhD diss., University of Edinburgh, 2009.

Makdisi, Ussama. Artillery of Heaven: American Missionaries and the Failed Conversion of the Middle East. Ithaca, NY: Cornell University Press, 2008.

Manela, Erez. The Wilsonian Moment: Self-Determination and the International Origins of Anticolonial Nationalism. Oxford: Oxford University Press, 2007. 
McCoy, Alfred W. Policing America's Empire: The United States, The Philippines, and the Rise of the Surveillance State. Madison, wi: University of Wisconsin Press, 2009.

Near East Relief. “Machine Age Humanitarianism.” The New Near East 8, no. 12 (December 1923).

Near East Relief. Report of International Golden Rule Sunday Observance. New York, NY: Near East Relief, 1926.

Neguib, Nefissa, and Inger Marie Okkenhaug, eds. Interpreting Welfare and Relief in the Middle East. Leiden: Brill, 2008.

Paulmann, Johannes. "Conjunctures in the History of International Humanitarian Aid during the Twentieth Century." Humanity: An International Journal of Human Rights, Humanitarianism, and Development 4, no. 2 (2013): 215-238.

Pedersen, Susan. "The Meaning of the Mandates System: An Argument." Geschichte und Gesellschaft 32, no. 4 (Oct-Dec. 2006): 560-582.

Pedersen, Susan. The Guardians: The League of Nations and the Crisis of Empire. Oxford: Oxford University Press, 2015.

Raffety, Edward. "Children and the New World." The New Near East 8, no. 12 (December 1923).

Robert, Khouri. “Histoire De La Médecine Au Liban.” Journal Médicale Libanais 58, no. 1 (2010): 28-44.

Rockefeller Foundation. The Rockefeller Foundation Annual Report. New York, NY: Rockefeller Foundation, 1916.

Rodakiewicz, Erla. Foreign Born: A Bulletin of American Service. New York, NY: Young Women's Christian Association USA, 1920.

Rodogno, Davide C. Against Massacre: Humanitarian Interventions in the Ottoman Empire, 1815-1914. Princeton, NJ: Princeton New Jersey, 2012.

Rodogno, Davide C. "Beyond Relief: A Sketch of the Near East Relief's Humanitarian Operations, 1918-1929." Monde(s): Histoire, Espace, Relations 2, no. 6 (2014):45-64.

Said, Edward. Orientalism. London: Penguin, 2006.

Schayegh, Cyrus, and Andrew Arsan, eds. The Routledge Handbook of the History of the Middle East Mandates. Abingdon: Routledge, 2015.

Stamatov, Peter. The Origins of Global Humanitarianism: Religions, Empires, and Advocacy. Cambridge: Cambridge University Press, 2013.

Tang, Kwong-Leung. Colonial State and Social Policy: Social Welfare Development in Hong Kong 1842-1997. Lanham, MD: University Press of America, 1998.

Tusan, Michelle Elizabeth. Smyrna's Ashes: Humanitarianism, Genocide, and the Birth of the Middle East. Berkeley and Los Angeles, CA: University of California Press, 2012.

Vickery, Charles V. Near East Relief: A Review for 1922 (Annual report to Congress). New York: Near East Relief, 1923.

Watenpaugh, Keith David. "Between Communal Survival and National Aspiration." In 
The Routledge Handbook of the History of the Middle East Mandates, edited by Cyrus Schayegh and Andrew Arsan (Abingdon: Routledge, 2015).

Watenpaugh, Keith David. Bread from Stones: The Middle East and the Making of Modern Humanitarianism. Berkeley and Los Angeles, CA: University of California Press, 2015 .

Watenpaugh, Keith. "The League of Nations' Rescue of Armenian Genocide Survivors and the Making of Modern Humanitarianism, 1920-1927." American Historical Review 115, no. 5 (2010): 1313-1339.

Weiss, Anne. "Education Removes Veil of Darkness for Women." The Pittsburgh Press, February 19, 1934.

Zimmerman, Jonathan. Innocents Abroad: American Teachers in the American Century. Cambridge, MA: Harvard University Press, 2008.

Zurz, Olivier. Philanthropy in America: A History. Princeton, NJ: Princeton University Press, 2012. 


\title{
Scottish Presbyterian Churches and Humanitarianism in the Interwar Middle East
}

\author{
Michael Marten
}

In this essay ${ }^{1}$ I seek to identify trends and patterns that offer us insights into ways of thinking about what the Scottish Presbyterian churches and their missionary organizations were doing in the European interwar period as they continued their long engagement in the Middle East, in particular focusing on Palestine. As they had been involved in the region since the $1840{ }^{2}{ }^{2}$ their presence meant they were reacting to changing circumstances, constantly in the process of seeking new ways to translate their understanding of Christianity in the region. This was not necessarily just about seeking new converts to Presbyterian Christianity, since although that would always be welcomed, their attempts to generate conversions were remarkably unsuccessful, as I have outlined elsewhere. ${ }^{3}$ Rather, over time they turned, as so many other Western church traditions did, into seeking to live a model or exemplary Christian life, as well as living out a civilizing mission that sought to modernize the world. This was, after all, a theme in the 1910 Edinburgh World Missionary Conference, demonstrated not least in the complex discussions around missionary-state relations. ${ }^{4}$

In reflecting on these contexts, it is important to be clear about the terms in use; all terminology is historically contingent, and so whilst contemporary scholars such as Michael Barnett define "humanitarianism" in ways that reflect

1 Early versions of this paper were presented at a workshop at Stirling University in December 2017, and at the Scottish Church History Society's conference in Glasgow in March 2018. I am grateful to participants at both events for helpful comments and reflections.

2 Michael Marten, Attempting to Bring the Gospel Home: Scottish Missions to Palestine, 1839-1917 (London: I.B. Tauris, 2006).

3 Marten, Attempting to Bring the Gospel Home, chapters 5 and 6.

4 See for example Brian Stanley, "Church, State, and the Hierarchy of 'Civilization': The Making of the 'Missions and Governments' Report at the World Missionary Conference, Edinburgh 1910," in The Imperial Horizons of British Protestant Missions, 1880-1914, ed. Andrew Porter (Grand Rapids: Eerdmans, 2003), 65, 8o ff. 
the present (e.g. "Humanitarianism is generally understood as assistance that occurs in the context of disasters; consequently, it is most readily applied to emergency relief and post-conflict recovery".5), such language can also be used historically, even if we need to be clear that the framing of such humanitarian work took place in many European missions - and often, certainly, for the Scots-in a setting where "the 'home missions in foreign countries' built the social infrastructure for overseas missions" (as Friedrich, Kaminsky and Löffler put $\left.i^{6}\right)$, rather than as interventions without an existing basis for engagement in a local area. This context is important when thinking about a broader definition such as Barnett's: as will become apparent here, humanitarianism and infrastructure are closely related.

Given that the Scots had been involved in Palestine for a considerable period prior to World War I (and indeed, elsewhere in the Middle East, with missions in Syria, Egypt and South Arabia (now Yemen), ${ }^{7}$ for example), it is important to summarize understandings of the missionary purpose and work in that time. Missionaries throughout the pre-wwI era had long engaged in broader socially-oriented work, centred on the key aspects of education and medicine, though their motivation for this was complex. Both forms of engagement were carried out in and for themselves, almost always with suitably qualified individuals (particularly notable in terms of medicine, where the growing professionalization of medicine in Europe in the mid-late 19th century also ensured the professionalization of medical missionary work). However, both methods can also be seen as a direct response to the overwhelming failure, especially in the Middle East, of the attempts to convert people directly through preaching and confrontation. Most of these missions had minimal success in achieving any significant number of converts, with such conversions as there were being mostly from Latin or Orthodox Christian traditions to Scottish Presbyterianism-no significant conversions of Muslims or Jews were ever recorded. ${ }^{8}$ This led to missionaries approaching these target populations

5 Michael Barnett, The International Humanitarian Order (London: Routledge, 2010), 2.

6 From the preface: Norbert Friedrich, Uwe Kaminsky, and Roland Löffler, The Social Dimension of Christian Missions in the Middle East: Historical Studies of the 19th and 2oth Centuries (Stuttgart: Franz Steiner Verlag, 2010), 8.

7 In Marten, Attempting to Bring the Gospel Home, I discuss the former two mission fields, on South Arabia, see James McLaren Ritchie, The Church of Scotland South Arabia Mission 18851978: A Historical and Critical Evaluation of the Mission founded by Hon. Ion Keith Falconer (Stoke-on-Trent: Tentmaker, 2006).

8 An interesting side effect of this is that such converts were regarded with some suspicion in wider missionary circles, as noted in Brian Stanley, "Defining the Boundaries of Christen- 
more indirectly, in part hoping that "converted" Christians would then go out and convert Muslims and Jews, though this was also a largely ineffective tactic.

\section{$2 \quad$ Education}

Education was the first of the additional methods employed by the churches in their missionary activity. ${ }^{9}$ Scottish education was highly regarded and the Jewish Mission Committees, in seeking to expand their influence, sought to use education from an early stage. In Palestine, the northern missions in Tiberias and Safad had educational and medical facilities (in Safad, medicine was later dropped), but one of the most important forays into education by Jewish missions was Jaffa's Tabeetha School, bequeathed to the Church of Scotland and the United Free Church of Scotland in 1911. After the war, this was developed and run as a joint effort by the Women's Jewish Mission Committees of the two churches (it could be said that this was a pioneering collaboration heralding the 1929 union between the two churches). ${ }^{10}$

Ottoman policy as pursued by Sultan Abdülhamid II emphasized the Islamic nature of his position in order to encourage the loyalty of his Arab notables, thereby seeking to ensure the power of Western states was kept within limited confines in the core regions of his empire. Through the various aspects of tanzimat reform, he encouraged, amongst other things, the creation of new professional schools and teacher training facilities. Although the later years of his reign saw ever-increasing censorship emerge, which to a certain extent impinged on education," it was understood that a populace able to compete with Western states was needed, and that both Ottoman and foreign schools could contribute to this. Concessions granted to Western powers for trade by the Ottoman empire included the necessary freedom for religious activity that gave missionary bodies the space within which to operate. The influx of foreign

dom: The Two Worlds of the World Missionary Conference, 1910," in International Bulletin of Missionary Research 30, no. 4 (October 2006): 173.

9 Max Warren, Social History and Christian Mission (London: SCM, 1967). Chapter 5 examines education in mission.

10 I have written about this: "Independent Women Missionaries in the Scottish School in Jaffa, 1918-1936: Identifying Subaltern Narratives," in Interpreting Relief and Welfare Activities in the Middle East, 1800-2005, eds. Nefissa Naguib and Inger Marie Okkenhaug, Social, Economic and Political Studies of the Middle East and Asia 103 (Leiden: Brill, 2008), 107128.

11 William L. Cleveland, A History of the Modern Middle East (Boulder: Westview, 1994), 115116. 
capital in the latter part of the 19th century ${ }^{12}$ of necessity reduced Ottoman control of some areas of public life; religious practice and education were among the areas where influence was most strongly contested.

The missionaries' educational services can be understood as part of the trend within the Ottoman Empire towards enabling greater participation in an international context dominated by Western European language and culture. For example, although Arabic was specified as the language of instruction to Gwladys Jones before she left for Palestine, she was also told that "Hebrew and English shall both be taught as languages"13 — the latter the language of the dominant imperial power and the former the language of the hoped-forconverts and putative self-governing individuals. Equally, the educators also extended their reach beyond the confines of the school curriculum into the private sphere: Nancy Stockdale cites Walker-Arnott, writing in 188o, before her school became part of the Scottish churches' missions, describing a pupil "actively altering her home environment as a result of her mission education". ${ }^{4}$ The children, it was hoped, would become an active influence on the parents, ultimately leading them to Christian belief. ${ }^{15}$ In that sense the prohibitions on schooling from various rabbis (in particular) that were regularly reported back to Scotland by the missionaries were seen as a mark of success in reaching the families of the children: surely, they reasoned, rabbis would only seek to limit Jewish children's access to Christian schools if they feared the success of the schools?

As shown by Stockdale, education was seen by the missionaries as offering not only an opportunity to encourage belief in (their version of) Christianity, but was also perceived to be a way of improving the culture and general environment of the people they found themselves amongst: a civilizational process,

12 Donald Quataert, "Part Iv: The Age of Reforms, 1812-1914," in An Economic and Social History of the Ottoman Empire, volume 2: 1600-1914, eds. Halil İnalcik and Donald Quartart (Cambridge: Cambridge University Press, 1994), 770-775 examines the effect of trends in the world economy on the Ottoman empire and includes analysis of the state of Ottoman finances; numerous other economic histories of the Ottoman Empire describe this in other ways.

13 United Free Church of Scotland, Women's Jewish Mission Committee (October 11, 1912).

14 Nancy Stockdale, "Gender and Colonialism in Palestine 180o-1948: Encounters among English, Arab and Jewish Women" (PhD diss., University of California Santa Barbara, 2000), 187 .

15 In connection with Anglican schools, "education work tended to foster a desire to join the church of the teachers [and this] led to complications later in relations with the Orthodox Church"; Anthony O'Mahony, "Church, State and the Christian Communities and the Holy Places of Palestine," in Christians in the Holy Land, eds. Michael Prior and William Taylor (London: Melisande, 1994), 17. 
in other words. Like the Americans in Syria, Scottish missionaries in Palestine, when pressed, would argue that their purpose was not explicitly the conversion of Ottoman subjects. ${ }^{16}$ Whilst their educational programmes were meant to civilize, they were not explicitly meant to Anglicize the indigenous population ("A gospel neither German nor British but Jewish must be preached to the $\mathrm{Jew}^{\prime \prime 17}$ ) in the way that Macaulay sought to turn children in India into English people "in taste, in opinion, in morals and in intellect"18 even if he could do nothing about their colour and blood (a "mental miscegenation", to use Benedict Anderson's language, Macaulay not seeking to convert the "idolaters" to Christianity, but to Englishness). We can see this reflected also in Ottoman Syria and Mandate Lebanon, ${ }^{19}$ and by extension, we can also see this with the Scottish missions in Palestine. In all of these instances, the missionaries were, of course, convinced of the superiority of their offering: as they saw it, their education was not just responsible for reading and writing, ${ }^{20}$ but included science (a new subject for most schools in Palestine at the time), ${ }^{21}$ "cleanliness"22 and "hygiene", ${ }^{23}$ aspects of domesticity (for girls: housework, knitting and embroidery, for example $)^{24}$ and industrial and agricultural training (for boys: although some fishing took place, further plans were frustrated) ${ }^{25}$ good behaviour (in

16 Selim Deringil, The Well-Protected Domains: Ideology and the Legitimation of Power in the Ottoman Empire, 1876-1909 (London: I.B. Tauris, 1998), 132.

17 United Free Church of Scotland, Monthly Record (1902): 125.

18 Macaulay argued for English education in order that in 30 years time "there will not be a single idolater among the respectable classes in Bengal"; Benedict Anderson, Imagined Communities (London: Verso, 1983; 2nd edition, 1991), 91.

19 See, for example, various essays in Julia Hauser, Christine B. Lindner, and Esther Möller, Entangled Education: Foreign and Local Schools in Ottoman Syria and Mandate Lebanon (19-2oth Centuries) (Beirut Orient-Institut, 2016).

"The children seem quite as sharp as our own. Five years ago not one girl in Tiberias could read, or distinguish between the bottom and the top of a page. Only one native woman in Tiberias knows the alphabet"; this is from a report of a visit to Fenton's school, Free Church of Scotland, Monthly and Missionary Record (June 1891): 172.

W.P. Livingstone, A Galilee Doctor: Being a Sketch of the Career of Dr. D.W. Torrance of Tiberias (London: Hodder \& Stoughton, n.d., prob. 1923), 23 .

22 From Jane Hope Grierson's impressions of the school in 1889, cited by Isobel Goodwin, May You Live to Be 120! The Story of Tabeetha School, Jaffa (Edinburgh: Saint Andrew Press, 2000) (on behalf of Friends of Tabeetha), 42.

23 These were introduced in Tabeetha in 1913 as a course of study, Goodwin, May You Live to Be 120!, 6o.

24 Goodwin, May You Live to Be 120!, 54. Inger Marie Okkenhaug, The Quality of Heroic Living, of High Endeavour and Adventure: Anglican Mission, Women and Education in Palestine, 1888-1948 (Leiden: Brill, 2002) elaborates on domesticity and academic achievement in Mandate-era Anglican schools in her fourth chapter.

Livingstone, A Galilee Doctor, 109. 
the widest sense $\left.{ }^{26}\right)$ : in other words, a holistic and rounded education as an ideal of the best education Scotland could offer:

It should be our aim to set a good example to the people in the art of training the young, and to establish model schools where mental improvement is energetically cultivated, where physical training is not neglected, and where spiritual nurture is sympathetically imparted. ${ }^{27}$

The Ottomans (correctly) perceived there to be a close relationship between the missionaries and their home countries' imperial ambitions and representatives, ${ }^{28}$ and this insidious intrusion of Western thought into Ottoman territories threatened, in the Sultan's view, the future of the existing order far more even than threats of an economic and military nature, which could be dealt with there and then, given sufficient planning and resources. ${ }^{29}$ This explains in part, at least, the problems around obtaining permission for school buildings. Often, ordinary houses were converted for use until such time as more appropriate premises could be obtained or built, but this came in for particularly strong criticism from the Ottomans because it was seen as a more covert means of opening schools. Ottoman concern at the missionaries' impact was undoubtedly justified, but the unwillingness to engage in large-scale con-

26 Livingstone cites a Greek Orthodox priest trying to prevent children from his community attending: "It is better ... that the girls should grow up ignorant and bad than that they should come under the influence of the Protestant women." Whether or not this was actually said is irrelevant in this context: it communicates the Scots' perception of the Greek priest's feelings about the effects their work would have on "his" girls; Livingstone, $A$ Galilee Doctor, 107. On the subsequent page he contrasts the "cheerful, well-ordered activity" of the girls in the Scots' school with their "wild and untrained condition" before their enrolment.

27 United Free Church of Scotland, Monthly Record, 555 .

28 Of course, at times this relationship could also be rather strained: "Missionary effort was by no means an agency of imperialist politics. Often it was opposed to the colonial authorities; pretty well always it put the interests of its converts first. Yet the success of the Lord was a function of imperialist advance." Eric Hobsbawm, The Age of Empire, 1875-1914 (London: Weidenfeld \& Nicolson, 1987), 71. A necessary correction, reflecting imperialistic patterns of thought, would be that the missionaries always put their perception of "the interests of ... [the] converts first".

29 Deringil, The Well-Protected Domains, 112; also: "by the 189os the missionaries had come to be regarded by the sultan as 'the most dangerous enemies to social order', among all the foreigners living in his domains" (114) because not "only did the missionaries undermine the efforts the Ottomans were making to legitimize the basis of their rule at home, they also proved influential in creating adverse conditions abroad by feeding the Western press with anti-Turkish sentiment" (113). 
flict with the European powers over this issue meant that although occasional harassment took place, the missionaries were relatively free to pursue their aims. ${ }^{30}$

In all of this, however, we should not overplay the missionaries' contribution to the issue of wider education, which was much smaller than that of the wider Ottoman state: although it is easy when examining missions to assume that large numbers of (Jewish, Christian, and Muslim) children passed through their schools and were therefore given a Western education that stood in competition to Ottoman establishments, Ottoman educational efforts under the aegis of the tanzimat reforms were undoubtedly more effective at reaching the majority of children - the missionaries, after all, could only afford to work in a limited number of localities, and central though these may often have been (major cities such as Jerusalem, Beirut, and Cairo, or important towns such as Aleppo, Tiberias, or Jaffa), there were far more Ottoman than missionary schools in the empire as a whole, and their influence was correspondingly greater, even if the quality of some of the schools was rather questionable. ${ }^{31}$ Where Ottoman and missionary schools competed, the hostility could be intense, with both sides using war-like language. ${ }^{32}$ Viewed from a historical perspective at least, the Ottoman aim of creating an educated middle-class that could later take the empire forward as the global context developed was fulfilled, whether they attended Ottoman or missionary schools, with those attending the latter mostly remaining within their existing communities and continuing to be loyal subjects.

In summary then, missionary educational efforts, although meeting resistance from the Ottoman state, were seen by the Scots-in common with many other Western missions - as a way for the missionaries to improve their relationship to the local population and gain inroads, via the children, to the families and communities of the area, particularly as the confrontational model was generally so unsuccessful in this regard.

30 Deringil, The Well-Protected Domains, 117-119.

31 Deringil, The Well-Protected Domains, 132-133.

32 Deringil, The Well-Protected Domains, 133-134 cites the war-like language of Ottoman officials. The language used by Scottish missionaries in many contexts resembled that of a military campaign - the frequent references to "occupying territory" and such like come to mind here (this use of language was typical of most Western missionaries). 
The second main model used to gain converts aside from direct confrontation was medicine. For the Scottish church missionaries it was in Tiberias and Safad in the $188 \mathrm{os}$, and several years later in Hebron, that medicine was fully exploited as a missionary approach.

In general terms it can be argued that from the perspective of missionary organizations, medical missions served (at least) three clear purposes: (a) they were a way of straightforwardly assisting people in need; (b) they resonated with the donating public who could easily witness the direct benefit to the target population of the funds they were giving; and (c) they provided a "lever" with which to gain access to a target population that might otherwise be reticent to allow access to missionaries-Andrew Walls quotes Herbert Lankaster of the CMs: "It was as heavy artillery that medical missions were used above all: in the less responsive fields, in Islamic societies, and above all in China". ${ }^{33}$ Walls' analysis of the development of medical missions in turn highlights four distinct factors: the imitative (direct obedience to Jesus, who healed people and commanded his disciples to do likewise), the humanitarian/philanthropic (a broad understanding of the "need" to assist the less well off), the utilitarian (preserving the health of the missionaries themselves), and the strategic ("the acceptability of medical missions when no other form of mission could gain a hearing"). ${ }^{34}$ We can see all of these markers reflected in the work in Tiberias, in different ways. For example, even at the very beginning of his career in Tiberias, Dr David Torrance wrote about his need for quality medicines, stating that, amongst other things, he was "anxious to make a good impression from the beginning, so as to gain the confidence of my patients at least". ${ }^{35}$ Occasional concern was expressed about the amount of medical work, and that this might create problems to the detriment of mission's work as a whole. ${ }^{36}$ Seen in this way, the strategic angle became self-defeating, as the means (medical care) took up so much time that the ends (preaching the gospel and creating con-

33 Andrew F. Walls, “'The Heavy Artillery of the Missionary Army': The Domestic Importance of the Nineteenth-Century Medical Missonary," in The Church and Healing, ed. W.J. Shiels (Oxford: Ecclesiastical History Society, 1982), 290.

34 Walls, "'Heavy Artillery of the Missionary Army', 288.

35 Free Church of Scotland, Monthly and Missionary Record (April 1, 1886): 105.

36 Walls, “The Heavy Artillery of the Missionary Army'," 292-294 expounds on the everexpanding investment required once a medical mission had been started. Even though in the 184 os the Committee may have known of only few examples on which to base such an assumption, it would have been obvious to them that the ongoing cost of medicines and equipment would be a financial burden. 
verts) became impossible to implement, or were in some way restricted, as this summary of speeches by Gustav Dalman of Leipzig held in Glasgow and Edinburgh indicates:

The value of medical missions is unquestionable, but perhaps their methods might be improved. The multitudes in the dispensary, to be seen and prescribed for by the doctor within certain hours, make spiritual work for him practically impossible. This is left, therefore, mainly to assistants ... [which] is not quite satisfactory. A Christian physician dwelling among the Jews, visiting their sick, the friend of their homes, the help of their poor, would find many doors open to him, and splendid openings for individual spiritual work. The annual number of cases might be less, but numbers here are of little importance. It would surely be a good principle for medical missions - fewer cases, more visiting of the sick, more individual work, not only by assistants, but by the medical missionary himself. ${ }^{37}$

However, the Scottish missionaries saw this differently. Whilst Torrance might have complained of overwork in the hospital (understandable given he was the main doctor, with, at times, 2,ooo patients being treated each month ${ }^{38}$ ), there are no records of him turning patients away (quite the contrary, he appears to have attempted to resolve every medical case he came across ${ }^{39}$ ), and whilst he was unhappy about the lack of opportunity afforded him to engage more with the population, he argued this highlighted the need for additional staff to share the medical cases and make more time for teaching and preaching. ${ }^{40}$ In addition, this argument, notable for its division between the "spiritual" and the "material", would not have been persuasive for Torrance and the like, who argued that missionary work consisted of a way of life as well as what was taught: i.e. by caring unreservedly for the sick, they saw themselves as living

37 United Free Church of Scotland, Monthly Record (1902): 125. Dalman had once applied to work in the Free Church of Scotland Galilee mission.

38 Ewing writing in Livingstone, A Galilee Doctor, 208.

39 Livingstone, $A$ Galilee Doctor, 217: "If the work is worth doing, it is worth doing well. No quack work in medical work.' But when faced with the tragedy of suffering in the mass ... what course could he adopt? He either had to ... turn away, or do what he could ... to ease their pain. He was too sympathetic to take the sterner course."- the quotation is from an address Torrance gave.

40 Overwhelmed by patients from both sides of the Jordan, he also (in September 1908) suggested opening an additional mission station elsewhere, but the funds for this were not available; Livingstone, A Galilee Doctor, 218. 
witnesses to their faith, exactly as the instructions to Torrance had stated when he first went to Palestine: "It should ever be kept in view that these results ['the enlightenment of their minds, the salvation of their souls' etc.] will be most effectively secured when, to the religious instruction communicated, is added the example of a holy and consistent life". ${ }^{41}$ This kind of holistic approach was typical of 19th-century Scottish Evangelicalism, which laid great stress on living a "godly life". We can also see a parallel to the educational approach here:

In addition to transferring medical skill and know-how they wanted to impart to their students a consciousness of the values implied in the exercise of the art, values of intercultural validity: the authentic commitment of those missions' doctors to help others, even at the expense of tremendous personal, career, and financial gain. They themselves were telling examples who showed that the power to do this work lay in a strong personal faith and commitment. ${ }^{42}$

Peter Williams has argued that particularly in Scottish Presbyterianism, the desire to educate was as much a part of the medical mission as the physical healing itself, and that this confluence of Christianity and civilization was an element of evangelization: in other words, the desire "for the erection of a christian civilization"43 - the pattern in relation to the educational model described above is clear here.

It is not always straightforward to clearly assess the extent to which the Scots succeeded in their ambitions in this regard, though the acceptance of converts into institutions with Western-style entrance criteria, such as the Syrian Protestant College in Beirut or institutions in Europe, does offer one measure of success. There certainly are examples of such individuals, one of the most famous being Leon Levison, who left Tiberias for Edinburgh after conversion to Christianity and became involved in the International Hebrew Christian Alliance as well as being for many decades the superintendent of the Edinburgh Jewish Medical Mission; he was eventually knighted, achieving a level of British civil recognition that perhaps even exceeded his impact on the Scottish and

\footnotetext{
41 Free Church of Scotland, Jewish Mission Committee (December 16, 1884).

42 Christoffer H. Grundmann, "The Contribution of Medical Missions: The Intercultural Transfer of Standards and Values," Academic Medicine 66, no. 12 (December 1991): 733.

43 C. Peter Williams, "Healing and Evangelism: The Place of Medicine in Later Victorian Missionary Thinking," in The Church and Healing, ed. W.J. Shiels (Oxford: Ecclesiastical History Society, 1982): 281 .
} 
international ecclesiastical scene. ${ }^{44}$ However, such stellar examples are rare, and the number of converts remained small.

We can see therefore, that whilst these two techniques were deployed, they clearly had ulterior motives, and although generally unsuccessful in generating significant numbers of converts, they were very clearly linked to the attempts to convert Jews, Muslims, and Orthodox Christians to Protestant Christianity.

With the unprecedented devastation of World War One, however, a different ethos emerged that focussed much more on the direct needs of the people concerned and that was theologically underpinned by a different rationale, bound less to the imperative to convert individuals or communities, and more connected to some of the themes that motivated what became the ecumenical movement. Whilst rampant nationalism and a belief in self-righteous divine sanction developed ever more strongly in mainstream circles in Europe after WWI, for some in the churches, especially those engaged in the wider world in missions and/or the ecumenical movement, a slightly different emphasis emerged. This was in part a result of the diminished emphasis placed on the nation-state of the missionaries' home-lands: as Jonathan Ebel has argued, ${ }^{45}$ whilst it was German soldiers who had "Gott mit uns" engraved into their beltbuckles, all sides thought they had God on their side, and it was the inevitable consequence of this not working out equally for all that led to some questioning of the importance of the nation-state altogether. Ellen Fleischmann has argued cogently that missionaries implicitly understood themselves as not so much citizens of a nation-state, but as citizens of the world, or better still, perhaps, as citizens of the world to come. This came about in part by seeing humanitarianism as part of the modernization of the world and therefore as

44 Frederick Levison, Christian and Jew: The Life of Leon Levison, 1881-1936 (Edinburgh: Pentland, 1989); that acceptance into the Western Christian fold could be tenuous is clear from the account of Levison's supposed recanting of his Christian faith when visiting Safad, in which Thomas Steele, one of the Galilee missionaries, played a significant, and apparently, somewhat malevolent role, with adverse consequences for Levison $\left(5^{2-}-54\right)$. Steele, recently arrived, had not known Levison personally, and reported the "recantation" on the basis of hearsay. The biographer, especially considering he is writing about his own family, generously notes (53): "That Mr Steele was a sick man who had to come home after only a year at Tiberias may have affected his attitude."

45 Jonathan Ebel, "War," in Encyclopedia of Missions and Missionaries, ed. Jonathan Bonk (New York: Routledge, 2007): 456 . 
part of the modernizing mission that virtually all missionaries of European and North American churches adopted wholesale. In that context, writing about female education, she notes that the contrast to modernity was backwardness: "Every society had its 'backward' women, who varied from place to place, and the source of whose backwardness elicited different explanations. This idea of the atavistic, superstitious woman holding back progress and modernity is a strikingly transnational idea" 46 that was replicated in capitalist, socialist, and colonial contexts, and that in missionary and other contexts was also clearly linked to racism. ${ }^{47}$ It was also linked to class, of course: "The "backward, traditional' woman to be modernized was recognizably lower or working class ...$^{\prime 48}$ and this elicited a common transnational response in humanitarian terms through the promotion of home economics as a way of redeeming and modernizing such women (though, as Fleischmann points out, regardless of whether the context was capitalist, socialist or colonial, the modernizing of domestic labour was inherently conservative in that it still "reinforced ... the gendered division of labour"49).

Humanitarianism took on new meaning in the wake of the crises that engulfed many former colonial areas after wwi. The demise of the Ottoman Empire and the creation of European mandates were just part of the transformation of many areas and populations, from the widespread transfers of Greek and Turkish populations from what became, respectively, solidly Turkish and Greek states, to the Armenian genocide, to the creation of Syria, Lebanon, Jordan, Iraq and Palestine, to the gradual and painful independence of Egyptand so on.

Throughout this time, Scottish involvement in the region continued, to a greater or lesser extent. Towards the end of the war, Scottish missionaries were heavily involved in the Syria and Palestine Relief Fund (SPRF), an ecumenical body to which both the United Free Church of Scotland and the Church of Scot-

46 Ellen Fleischmann, "At Home in the World: Globalizing Domesticity through Home Economics in the Interwar Years," in Transnational and Historical Perspectives on Global Health, Welfare and Humanitarianism, eds. Ellen Fleischmann, Sonya Grypma, Michael Marten, and Inger Marie Okkenhaug (Kristiansand: Portal, 2013), 173.

A considerable body of work exists examining racism in missionary contexts. I have discussed this in relation to Palestine (Marten, Attempting to Bring the Gospel Home, chapter 4 and 5), but for a more general overview based on language usage, see e.g. Brian Stanley, "From 'the Poor Heathen' to 'the Glory and Honour of All Nations': Vocabularies of Race and Custom in Protestant Missions, 1844-1928," International Bulletin of Missionary Research 34, no. 1 (January 2010): 3-10.

48 Fleischmann, "At Home in the World," 175.

49 Fleischmann, "At Home in the World," 180. 
land had contributed, and which was dealing with most of the British churches' efforts to provide relief in the region during the war. The churches participated in relief efforts, which given the geopious sentiment around the occupation of Palestine by General Allenby and all that that might herald for Jews, seemed to raise substantial sums: there are records of $£ 25,600$ being raised in the "War Fund". ${ }^{50}$ Staff served in many different areas during and immediately after the war: for example, Dr Alexander Paterson of the Hebron hospital was appointed a Lieutenant in the Royal Army Medical Corps and served in various localities in Britain before being sent to Egypt and then on to Hebron as Principal Medical Officer under the Occupied Enemy Territory Administration; he was then connected to the afore-mentioned SPRF. ${ }^{51}$ Paterson's long-standing lack of interest in directly generating conversions from Jews or Muslims points to his greater interest in providing a social service which on the side offered the opportunity to evangelize (I have argued in the past that he perhaps saw his medical services as less of a tool of conversion or means of access than other missionaries ${ }^{52}$ ). In addition to this, when he did speak of conversion, he was quite adamant that although his work was overseen by a Jewish mission committee, he was serving (and hoping to reach) Jews as well as Muslims, as he stated in his first address to the church's General Assembly. This became the pattern much more in the post-WWI era, and the SPRF was a good avenue for such work: in 1919 the Church of Scotland's General Assembly was told by "distributing food and clothing, by medical relief, by its care of orphans, and in countless other ways, the Fund has given practical illustration of the teaching of Christ to all, irrespective of race or creed." ${ }^{\prime 53}$ It was, however, closed the following year, its "purpose having been accomplished"54_in this regard, what was meant was that the more normal work of the missions could resume, and there was perceived to be less of a need for emergency relief work. Humanitarianism once again became more closely connected to the existing institutions and the ostensible desire to achieve converts to Protestantism. However, after WWI, a new challenge became ever more apparent to the missionaries in the form of Zionism.

\footnotetext{
$50 \quad$ Livingstone, $A$ Galilee Doctor, 252.

51 United Free Church of Scotland, Jewish Mission Committee (March 16, 1915); William Ewing, Paterson of Hebron: "The Hakim" of Missionary Life in the Mountain of Judah (London, n.d. prob. 1925), 155-161.

$5^{2}$ Marten, Attempting to Bring the Gospel Home, see in particular 99-109.

53 Church of Scotland, Jewish Mission Committee Report (1919): 228.

54 Church of Scotland, Jewish Mission Committee Report (1920): 251.
} 
In Palestine, the concern for humanitarian involvement became centred around a question of competition: the United Free Church of Scotland Jewish Mission Committee debate in 1921 recorded that: "The Zionists were throwing no small energy into their schools and hospitals, and by so doing challenged mission schools in the standard of teaching and general equipment. The same was true of their hospitals". ${ }^{55}$ This, it was argued, necessitated clear competitive approaches in order to ensure that the missions were successful in the face of such difficulties:

A situation of this nature compelled the members of the Committee to re-think the policy of the Church in Palestine. It would be wrong to dissipate men [sic] or means in directions which promised a poor result, either by reason of the paucity of Jews [in that area], or by reason of such conditions of work as gave the missionary faint promise of effective service. And, second, whatever agency, educational or medical the Church employed must be of the first efficiency; it would be simple waste otherwise. Unless school and hospital be equipped up to the limit of scientific modern equipment, the work of either would be futile. ${ }^{56}$

This was emphasized in many subsequent years: for example, in 1922, the Assembly was told the Zionists' "avowed purpose" was "to make both Christian school and hospital superfluous so far as the Jew is concerned",57 and in 1923 it was noted that, "Aggressive Zionism in both school and hospital emphasized the need for the work in both directions being of first-class quality". ${ }^{58}$ And so it went on, year after year. In 1929, at the last Assembly of the United Free Church before the bulk of it reunited with the Church of Scotland, there was again a heartfelt plea for funds to help support the mission in the face of all these challenges it faced. ${ }^{59}$ There was a fine line being walked here: on the one hand the church needed to communicate to its supporters the need for ongoing support and engagement in the work, recognizing that many members would have themselves experienced ever-improving educational and medical facilit-

55 United Free Church of Scotland, General Assembly Jewish Mission Committee, Proceedings and Debates (1921): 84 .

56 Ibid. 85 .

57 United Free Church of Scotland, General Assembly Jewish Mission Committee, Proceedings and Debates (1922): 86.

58 United Free Church of Scotland, General Assembly Jewish Mission Committee, Proceedings and Debates (1923): 76 .

59 United Free Church of Scotland, General Assembly Jewish Mission Committee, Proceedings and Debates (1929): 102. 
ies at home and would expect this to be replicated by the missions in what were perceived to be less advanced contexts such as Palestine, whilst on the other, it was important for them to convey a need to invest further in the existing work as many of the Zionist facilities would have been created by Jews educated in the West able to replicate standards they had grown to expect there-and this emphasis on modernity came at a considerable financial cost for the United Free Church of Scotland, of course.

With the 1929 union of the United Free and the Church of Scotland, ${ }^{60}$ however, these emphases began to change slightly. The Church of Scotland had had only limited engagement in Palestine prior to the union, primarily through a joint administration by the Women's Jewish Mission Committee of Tabeetha School in Jaffa, which was run with the United Free Church of Scotland's parallel committee. The changed emphases were substantially contingent upon the context in Palestine. In the 193 o Report, for example, a reference to the 1929 riots was followed by noting that,

over $£ 200$ was remitted to [the] Safad and Tiberias [mission stations] to provide food and clothing, and at these and other centres our workers acted as agents for other organisations, such as the Hebrew Christian Alliance and the British Red Crescent Society, to alleviate the sufferings of those who were affected by the outbreak. ${ }^{61}$

This sentiment was motivated in substantial measure by staff on the ground: for example, Rev. Samuel Hanna Semple, the Principal of the Scots College in Safad, wrote in his mission station report that year that whilst the riots were regrettable, "it seemed to be our duty to refrain from partisanship and to confine our energies to the relief of distress wherever we found it". ${ }^{62}$ The following year, this lack of partisanship in offering relief was given as the reason the College had been able to open properly again so quickly: "The unselfish and exacting labours of Mr. and Mrs. Semple in relieving distress to Jew and Arab alike for long after the riots, and their fairness to all parties, left their mark on the people".63 Such work took place against the backdrop of severe global economic depression, of course, ${ }^{64}$ and whilst this had an effect on the Middle East too, it was not felt as acutely in Palestine as in the Western context, including

6o The union resulted in the new body simply being known as the Church of Scotland.

61 Church of Scotland, Jewish Mission Committee Report (1930): 872.

62 Ibid. 908.

63 Church of Scotland, Jewish Mission Committee Report (1931): 853 .

64 Church of Scotland, Jewish Mission Committee Report (1932): 785 . 
in ecclesiastical donor circles. ${ }^{65}$ The coinciding of the Palestine political crisis that necessitated involvement in relief work with the economic depression meant that achieving substantial donations and support from congregations and members was simply more of a challenge for the Church of Scotland.

The next few years mention little in the way of direct emergency humanitarianism, though the Scots' self-perception of their work in encouraging progress and development in relation to modernity is offered regularly: noting the illustrious onward study of many graduates of the Scots College, for example, it was apparent that the "Scots College is playing a large part in training the future leaders of the country"66 — though even in the following year, it was necessary to admit that there were ever fewer posts in government available for such students. ${ }^{67}$ This highlighted a growing problem for the graduating students, one that would only ever really be satisfactorily addressed by the church's Tabeetha School in Jaffa well after the creation of the state of Israel.

There were droughts and floods in these years, with a corresponding impact on the missions' facilities, especially given that many of the people that the Scots most closely related to were involved in the agricultural economy. The missions, under the direction of the Jewish Mission Committee and the Women's Jewish Mission Committee, generally sought to do what they could, though school numbers declined as some parents' ability to support their children's education diminished; some accommodation of this problem occurred, but the missions were always pressed for resources. However, it is with the beginnings of the 1936-1939 Arab Revolt that we can see a significant change occurring: in the 1937 Assembly papers, the strikes are mentioned primarily in relation to reduced involvement by all in the work of the missions, whether educational or medical — though no other critique or engagement occurs that year, perhaps in the expectation that the Revolt would not last. ${ }^{68}$ In 1938 , as tensions continued, the only direct mention of the Revolt is the treatment of a British soldier in Tiberias and tensions between "brigands" and over 1,000 troops, ${ }^{69}$ though the report also discusses the future of the Peel Report, which the British government had initiated hoping it would bring peace to the country by proposing the separation of Palestine into two states, Arab and Jewish. ${ }^{70}$ In the May 1939 Church of Scotland General Assembly Report, with World War II

\footnotetext{
65 Ilan Pappe, The Modern Middle East (Abingdon: Routledge, 2005), 43-45.

66 Church of Scotland, Jewish Mission Committee Report (1932): 791.

67 Church of Scotland, Jewish Mission Committee Report (1933): 729 .

68 Church of Scotland, Jewish Mission Committee Report (1937): 863-865.

69 Church of Scotland, Jewish Mission Committee Report (1938): 741.

70 Ibid. $73^{2-733 .}$
} 
just a few months away, the poverty and "general deterioration in the decencies of life" are bemoaned, but not directly attributed to the political unrest in the country, ${ }^{71}$ which is mentioned but briefly in the report, and blamed for travel restrictions and more, ${ }^{72}$ however, this comes across as more of a troublesome inconvenience, rather than a seismic shift in the power dynamics in Palestine.

\section{5}

Conclusions

This essay's brief portrayal of Church of Scotland public statements highlights several changes in direction for the missions, whilst noting the contingent nature of such changes. There are several direct conclusions that can be drawn in relation to the wider context.

Firstly, during World War I and the immediate aftermath, substantial relief efforts were organized, mostly ecumenically - this was a direct form of humanitarian relief, perhaps most obviously directly linked to the definition by Michael Barnett noted above.

Secondly, during the 1920s, although the United Free Church of Scotland worked at providing some measure of relief to those in need, it continually sought to defend the Church against the perceived influence of Zionism. This, then, was a form of humanitarianism, but one that reflected pre-World War I understandings of education and medicine as tools in the desire to achieve missionary aims, coupled with direct competition (in the church's eyes) with the ambitions of the Zionist movement. This was not uncomplicated, as there was also a certain admiration by the Scots of the Zionist colonizers and their advances in agriculture and economy, a position that understood the bringing of European modernity to Palestine-it was simply that the missionaries would have preferred the local Palestinian population to have adopted their version of European modernity, rather than that of the Zionists.

Thirdly, with the global depression and the uniting of the two churches, occasional mentions are made of relief and humanitarian work, particularly at the Scots College, but interest in this kind of work diminishes, even though the need is there. Whilst it is possible to see the passing of the Tiberias mission founder David Torrance (1923) and retiral shortly thereafter of Alexander Paterson from Hebron - two of the longest-serving male missionaries in Palestine-as perhaps playing a role here, we can also point to a parallel to

71 Church of Scotland, Jewish Mission Committee Report (1939): 704.

72 Ibid. $702-703$. 
the work of Maria Småberg in describing the Anglican approach to the British authorities as an "ambiguous friendship", ${ }^{73}$ and this, to some extent, describes also what is happening for the Scots. Småberg argues that there was a continual co-operation with the governmental authorities on the part of the Anglicans, and we can argue similarly for the Scots: it is no coincidence that the new St Andrews Memorial Church in Jerusalem was the "home" for many Scots who served the British government's Mandate authority in Jerusalem. The need, therefore, to provide full humanitarian services diminishes somewhat as the Scots' own government was governing the country and providing services to many. Cynics might argue that Scottish provision was therefore reduced to simply supplementing the work of government, and mostly in Palestinian Arab areas, as the Zionist movement offered such substantial services to the Jewish population.

Finally, with the Arab Revolt, we can see again the desire to offer some relief where possible, though there is little recognition of the significance of the wider political and social changes heralded by the growing influence of Zionism and the response in the form of the Arab Revolt. However, the apparent thinning of support for humanitarian work in Palestine by the late 1930s is not to be dismissed out of hand: in fact, we could say that there was increasing recognition of the need for support and help-just not necessarily where the mission stations were located, and not in Palestine. The key to this understanding is to be found in the opening of the 1939 Jewish Mission Committee Report to the Church of Scotland's General Assembly, which discusses the persecution of Jews world-wide, particularly by the Nazi regime in Germany:

Beyond all anticipation of what persecution in its recklessness might do, the worst of perils ever dreamed of has been surpassed, and such an avalanche of trouble has swept over the Jewish people that the Church's relation to them can no longer be thought of as simply the relation of a Christian missionary Church to a non-Christian people, but as the relation of the Church to a great political, racial, and humanitarian problem. ${ }^{74}$

The report does, in typically—for that time-anti-Semitic fashion, ${ }^{75}$ go on to blame "the Jews" for their "stubborn" nature in being unwilling to become

73 Maria Småberg, Ambivalent Friendship-Anglican Conflict Handling and Education for Peace in Jerusalem, 1920-1948 (Lund: Lund University Press, 2005).

74 Church of Scotland, Jewish Mission Committee Report (1939): 691.

75 This was part of a long tradition of virulent anti-Semitism in Jewish mission circles, as noted, for example, in Marten, Attempting to Bring the Gospel Home, 136 and elsewhere. 
Christian, but despite this, it does clearly enunciate a serious concern for Jews well beyond Palestine. Being overwhelmed by the news coming out of continental Europe and wanting to help Jews there-for example, in their Budapest and other European missions - the Jewish Mission Committee had to restrict the level of support they could offer in Palestine, a priority that was reflected in their annual General Assembly Report, one of the primary mechanisms for communicating their work and intentions to the wider Church. This undoubtedly had negative effects on the Church's missions' engagement with local Jewish-Arab relations in Palestine-but within months, all of this would be beyond the control of the Church of Scotland as it and Britain as a whole were overwhelmed by the outbreak of World War II. Zionist terrorism in Palestine in support of the creation of a Jewish state during and immediately after World War Two, the Zionist-Arab war, and the devastating impact of the Nakba just three short years later, had catastrophic humanitarian effects for the Palestinian Arab population that the churches-including the Church of Scotland—struggled to deal with. ${ }^{76}$ By this time, however, wider global humanitarian understandings had emerged in the context of the postWorld War Two settlement, the creation of the United Nations and its agencies (including UNHCR, UNRWA, and the WHO), the development of new understandings of human rights and refugee priorities - and the churches' involvement in the Palestinian refugee crisis was proportionately rather minimal when compared to the work carried out by these new international agencies.

\section{Bibliography}

\section{Church of Scotland}

Church of Scotland. Jewish Mission Committee Report (1919). Church of Scotland. Jewish Mission Committee Report (1920). Church of Scotland. Jewish Mission Committee Report (1930). Church of Scotland. Jewish Mission Committee Report (1931). Church of Scotland. Jewish Mission Committee Report (1932). Church of Scotland. Jewish Mission Committee Report (1933). Church of Scotland. Jewish Mission Committee Report (1937).

76 For a brief overview of post-World War II context, see Michael Marten, "Indigenisation and Contextualisation-The Example of Anglican and Presbyterian Churches in the Holy Land," in Christianity and Jerusalem: Theology and Politics in the Holy Land, ed. Anthony O'Mahony (London: Gracewing Publishers, 2005), 115-137. 
Church of Scotland. Jewish Mission Committee Report (1938).

Church of Scotland. Jewish Mission Committee Report (1939).

\section{Free Church of Scotland}

Free Church of Scotland. Jewish Mission Committee (December 12, 1884).

Free Church of Scotland. Monthly and Missionary Record (April 1, 1886).

Free Church of Scotland. Monthly and Missionary Record (June 1891).

\section{United Free Church of Scotland}

United Free Church of Scotland. Monthly Record (1902).

United Free Church of Scotland. Women's Jewish Mission Committee (October 11, 1912).

United Free Church of Scotland. Jewish Mission Committee (March 16, 1915).

United Free Church of Scotland. General Assembly Jewish Mission Committee, Proceedings and Debates (1921).

United Free Church of Scotland. General Assembly Jewish Mission Committee, Proceedings and Debates (1922).

United Free Church of Scotland. General Assembly Jewish Mission Committee, Proceedings and Debates (1923).

United Free Church of Scotland. General Assembly Jewish Mission Committee, Proceedings and Debates (1929).

\section{Books, Chapters, and Articles}

Anderson, Benedict. Imagined Communities. London: Verso, 1983; 2nd edition, 1991.

Barnett, Michael. The International Humanitarian Order. London: Routledge, 2010.

Cleveland, William L. A History of the Modern Middle East. Boulder: Westview, 1994.

Deringil, Selim. The Well-Protected Domains: Ideology and the Legitimation of Power in the Ottoman Empire, 1876-19o9. London: I.B. Tauris, 1998.

Ebel, Jonathan. "War." In Encyclopedia of missions and missionaries, edited by Jonathan Bonk, 453-458. New York: Routledge, 2007.

Ewing, William. Paterson of Hebron: "The Hakim" of Missionary Life in the Mountain of Judah. London, n.d., prob. 1925.

Fleischmann, Ellen. "At Home in the World: Globalizing Domesticity through Home Economics in the Interwar Years." In Transnational and Historical Perspectives on Global Health, Welfare and Humanitarianism, edited by Ellen Fleischmann, Sonya Grypma, Michael Marten, and Inger Marie Okkenhaug, 158-181. Kristiansand: Portal, 2013.

Friedrich, Norbert, Uwe Kaminsky, and Roland Löffler. The Social Dimension of Christian Missions in the Middle East: Historical Studies of the 19th and 2oth Centuries. Stuttgart: Franz Steiner Verlag, 2010. 
Goodwin, Isobel. May You Live to Be 120! The Story of Tabeetha School, Jaffa. Edinburgh: Saint Andrew Press, 2000. On behalf of Friends of Tabeetha.

Grundmann, Christoffer H. "The Contribution of Medical Missions: The Intercultural Transfer of Standards and Values." Academic Medicine 66, no. 12 (December 1991): $731-733$.

Hauser, Julia, Christine B. Lindner, and Esther Möller. Entangled Education: Foreign and Local Schools in Ottoman Syria and Mandate Lebanon (19-2oth Centuries). Beirut: Orient-Institut, 2016.

Hobsbawm, Eric. The Age of Empire, 1875-1914. London: Weidenfeld \& Nicolson, 1987. Levison, Frederick. Christian and Jew: The Life of Leon Levison, 1881-1936. Edinburgh: Pentland, 1989.

Livingstone, W.P. A Galilee Doctor: Being a Sketch of the Career of Dr. D.W. Torrance of Tiberias. London: Hodder \& Stoughton, n.d. prob. 1923.

Marten, Michael. "Indigenisation and Contextualisation-The Example of Anglican and Presbyterian Churches in the Holy Land." In Christianity and Jerusalem: Theology and Politics in the Holy Land, edited by Anthony O'Mahony, 115-137. London: Gracewing Publishers, 2005.

Marten, Michael. Attempting to Bring the Gospel Home: Scottish Missions to Palestine, 1839-1917. London: I.B. Tauris, 2006.

Marten, Michael. "Independent Women Missionaries in the Scottish School in Jaffa, 1918-1936: Identifying Subaltern Narratives." In Interpreting Relief and Welfare Activities in the Middle East: 1800-2005, edited by Nefissa Naguib and Inger Marie Okkenhaug, 107-128. Social, Economic and Political Studies of the Middle East and Asia 103. Leiden: Brill, 2008.

McLaren Ritchie, James. The Church of Scotland South Arabia Mission 1885-1978: A Historical and Critical Evaluation of the Mission founded by Hon. Ion Keith Falconer. Stoke-on-Trent: Tentmaker, 2006.

Okkenhaug, Inger Marie. The Quality of Heroic Living, of High Endeavour and Adventure: Anglican Mission, Women and Education in Palestine, 1888-1948. Leiden: Brill, 2002.

O'Mahony, Anthony. "Church, State and the Christian Communities and the Holy Places of Palestine." In Christians in the Holy Land, edited by Michael Prior and William Taylor, 11-27. London: Melisande, 1994.

Pappe, Ilan. The Modern Middle East. Abingdon: Routledge, 2005.

Quataert, Donald. "Part IV: The Age of Reforms, 1812-1914." In An Economic and Social History of the Ottoman Empire, volume 2:1600-1914, edited by Halil İnalcik and Donald Quartart, 770-775. Cambridge: Cambridge University Press, 1994.

Småberg, Maria. Ambivalent Friendship - Anglican Conflict Handling and Education for Peace in Jerusalem, 1920-1948. Lund: Lund University Press, 2005.

Stanley, Brian. “Church, State, and the Hierarchy of 'Civilization': The Making of the 'Missions and Governments' Report at the World Missionary Conference, Edinburgh 
1910." In The Imperial Horizons of British Protestant Missions, 1880-1914, edited by Andrew Porter. Grand Rapids: Eerdmans, 2003.

Stanley, Brian. "Defining the Boundaries of Christendom: The Two Worlds of the World Missionary Conference, 1910." In International Bulletin of Missionary Research 3o, no. 4 (October 2006): 171-176.

Stanley, Brian. "From 'the Poor Heathen' to 'the Glory and Honour of All Nations': Vocabularies of Race and Custom in Protestant Missions, 1844-1928." International Bulletin of Missionary Research 34, no. 1 (January 2010).

Stockdale, Nancy. "Gender and Colonialism in Palestine 180o-1948: Encounters among English, Arab and Jewish Women." PhD diss., University of California Santa Barbara, 2000.

Walls, Andrew F. “'The Heavy Artillery of the Missionary Army': The Domestic Importance of the Nineteenth-Century Medical Missionary." In The Church and Healing, edited by W.J. Shiels, 287-297. Oxford: Ecclesiastical History Society, 1982.

Warren, Max. Social History and Christian Mission. London: sсм, 1967.

Williams, C. Peter. "Healing and Evangelism: The Place of Medicine in Later Victorian Missionary Thinking." In The Church and Healing, edited by W.J. Shiels, 271-285. Oxford: Ecclesiastical History Society, 1982. 
PART 4

Epilogue: Impact of the 1948 Crisis 
- 978-90-04-43453- 0

Downloaded from Brill.com04/26/2023 01:14:44PM via free access 


\title{
Confined by Conflict, Run by Relief: Arabs, Jews, and the Finnish Mission in Jerusalem, 1940-1950
}

\author{
Seija Jalagin
}

In November 1947, the United Nations' decision to accept the partition of Palestine reached Jerusalem, where Finnish missionaries for the Jews also rejoiced, together with their local co-workers, children at the mission school and their Jewish neighbours. "The partition did not fulfil all hopes", wrote Aili Havas, the leader of the mission, in her annual report and later in her memoir that was published in 1958. She also described the antagonism that followed:

The Arabs declared a three-day strike, started to burn down Jewish shops and blow up Jewish houses in those parts of the town where Jewish and Arab shops stood next to one another. The Jews, who lived amidst Arabs, left their homes and moved to completely Jewish areas and the Arabs moved from the Jewish Quarter to the Old City. The partition was complete. $^{1}$

This article investigates the views of the Finnish missionaries towards the Arabs, and more broadly, the political and social circumstances in Palestine/ Israel. The Finnish mission focused solely on the Jews and was, like many other foreign religious actors, a marginal, grass-roots actor during the turbulent 1940s in the Middle East. Regardless of their size the different Christian denominations, missions and an increasing number of pilgrims were participants in the religious, social and political reconfiguring of Mandatory Palestine, where the British rulers struggled to balance the coexistence of the Arab population and the Yishuv, the Jewish settlement. What makes the Finnish mission particularly interesting is that the Finns, much like the other Nordic missions and missionaries, promoted an idea of the Nordic people as politically neutral in the Middle East and in other colonial settings. They claimed neutrality, as opposed to the

1 Aili Havas, Työkenttäni Israel (Helsinki: Suomen Lähetysseura, 1958), 229-23o. 
British and other missions and church bodies from European powers that had a presence in the Middle East due to Mandatory rule and other historical reasons. $^{2}$

The Nordic missions, in fact, had no political back-up-or oppositionfrom their home governments but it would be false to assume that the missionaries were politically neutral. As the case of the Finnish mission indicates, living amidst the political, religious, and social reality of Mandatory Palestine, and later in the State of Israel, drew partition lines not only through the local population but also through the foreign missionaries.

Of particular interest in this chapter is how the Finnish missionaries viewed the political and religious development in Palestine and how this linked to their own political views. The viewpoints of the missionaries were, of course, strongly affected by their religious ideology but it is equally important to explore how they related to their political standpoint. Going about their daily lives in Jerusalem and building a social reality in relation to local people, the missionaries became internal others, ${ }^{3}$ informed outsiders, who relayed knowledge about Palestine/Israel to their home countries and, at the same time, reflected on the local reality with their own national and cultural insights. They were regarded as either useful or harmful internal others by the ruling authorities - the administrators during the Ottoman era, British Mandate, or later the government of Israel - or they were simply tolerated. In much the same way, local people perhaps thought that the missionaries were either aligning themselves with the ruling authorities or distancing themselves from them. In order to analyse the missionaries' views, I rely on their correspondence with mission leaders in Finland as well as their published writings in mission and other religious papers, where they reported on the situation in Palestine/Israel and commented on its political, economic and social development.

2 For a broader view of the Christian presence in Palestine, see for example Anthony O'Mahony, ed., The Christian Communities of Jerusalem and the Holy Land (Cardiff: University of Wales Press, 2003).

3 "Internal Other" is a concept discussed by, e.g., Johnson and Coleman when addressing regional differences and nation-building. They define it "as the intentional construction of a region as different from, perhaps even antithetical to, national norms and values as an element of nation-building." For Johnson and Coleman, and to the geography researchers who have employed the concept, "internal other" centres on geographic and spatial entities, and not on individuals. Corey Johnson and Amanda Coleman, "The Internal Other: Exploring the Dialectical Relationship Between Regional Exclusion and the Construction of National Identity," Annals of The Association Of American Geographers 102, no. 4 (2012): 863-880, https:// doi:10.1080/00045608.2011.602934. 


\section{Lived Christianity among the Jews}

The Finnish mission to the Jews in Palestine was launched in the 1920 after decades of interest in Christianizing the Jews. Mission work among the Jews in Finland, who had mostly come from Russia and had no civil rights in the country before the independence (gained from Russian rule in 1917), had not borne much fruit. A few individual missionaries had been assigned to work among the Jews in continental Europe, but in general, the whole effort was small and unorganized until the oldest and largest mission organization in Finland, the Finnish Mission Society took it over. ${ }^{4}$ FMS was established in 1859; today it is known as the Finnish Evangelical Lutheran Mission (FELM). It is a mainstream Lutheran mission and a long-time co-operative organization with the Evangelical Lutheran Church of Finland, ${ }^{5}$ as well as the largest development co-operation body in Finland. It has historically operated in Southwest Africa (from 1870) and in China (from 1902), before expanding to other areas in Africa, Asia, and Latin America. ${ }^{6}$

FELM's mission work in Palestine started in 1924 when the Reverend Aapeli Saarisalo, later Professor of Oriental languages at the University of Helsinki, was sent there as a missionary. During his two years in the area, the mission made very little progress and in 1926 the Saarisalo family returned home. Saarisalo had prioritized scholarly work but also disseminated Bibles among the Jews and the Arabs that he encountered on his field trips in the

4 There was an increasing interest in the so-called Jewish question in Finland since the 1870s. In FMS several leading characters were enthusiastic about mission work among the Jews. Some of them had in the 188 os tried to establish an independent mission association to proselytize the Jews, but the Czar of Russia had refused the application. Funds for mission work among Jews were collected in the parishes of the Evangelical Lutheran Church of Finland. An early example of more institutional work among the Jews is the school, or rather kindergarten, for Jewish children in Helsinki, in 1889-1891, and before that shortly in Turku and Helsinki around 1878-1881, with Finnish teachers. Toivo Saarilahti, Sata vuotta suomalaista lähetystyötä. 1, 3, Lähetystyön läpimurto: Suomen lähetysseuran toiminta kotimaassa 1895-1913 (Helsinki: Suomen Lähetysseura, 1989), 101-107; Per Wallendorff, Suomen lähetysseuran juutalaislähetystyön historia (Helsinki: Suomen Lähetysseura, 1958), 14-16.

5 The Evangelical Lutheran Church of Finland is a "folk" or "national" church, with less than $70 \%$ of the population as its members, and it has the right to collect taxes from these members via the state taxation system. The Orthodox Church of Finland, an autonomous church under the Ecumenical Patriarchate of Constantinople, has a similar status, with $1.1 \%$ of the population of Finland as its members.

6 The work in Israel continues today but has since the late 196os been directed first towards the Arabs, and later along more ecumenical lines among the diverse ethnic and religious groups in the area. 
region. ${ }^{7}$ It took until 1932 to send the next missionary to Palestine. Aili Havas (1903-1988), who held university degrees in both theology and history and had been internationally active in the Christian student movement, was commissioned by the FELM director to settle in Jerusalem as a missionary to the Jews with no specific instructions other than "let God show you the way from the very beginning. We do not wish to take our civilization there, they do not need it, nor do we want to take our own Lutheran Church there but only Christ". ${ }^{8}$

During the next 37 years in Palestine/Israel, Havas became the undisputed leader of the Finnish mission to the Jews there. She had an academic orientation and was, in general, a steady person, who succeeded in running and navigating the mission in the politically turbulent, multi-ethnic, and culturally diverse surroundings. On the other hand, it could also be said that her success resulted from her finding a niche for the FELM's mission work among the Jews. This becomes vividly clear when investigating the Finnish mission during the World War II years and the restless times at the end of the British Mandate and the evolution of the State of Israel. When most British missionaries left Palestine at the end of the Mandate in 1947 and some Nordic missions gave up their work among the Arabs, the Finnish missionaries found opportunities among the Jews. This, however, required careful balancing between Jewish nation-building and religious diversity.

After her arrival in Palestine as a young academic, Havas had enrolled at the Hebrew University in Jerusalem. Soon she also aimed at getting a $\mathrm{PhD}$ degree there. Her missionary strategy was based on living among the Jews as an openly Christian person, and she used every opportunity to make friends with her fellow students. Gradually this developed into a plan to open a student home where she could gather young Jews to study the Bible and discuss religious issues. Soon after getting the student home started Havas had to leave Jerusalem in 1938 to go on furlough in Finland for rest and recovery from pulmonary tuberculosis.

When she returned in 1940, the mission home she had left under the care of a Swiss-Jewish female friend was full of refugees from Europe. The mission house had turned into a "Samaritan inn", ${ }^{9}$ as one of the young men residing there called the home that also gave shelter to a mother with a young daughter as well two young orphaned children. Havas prioritized to care for the children

7 André Swanström, From Failed Mission to Apocalyptic Admiration: Perspectives on Finnish Christian Zionism (Åbo: Åbo Akademi, 2007), 8o-82.

8 Havas, Työkenttäni Israel, 29-30.

9 Aili Havas to Rauha Moisio, Jerusalem (May 21, 1940). Folder 15, Aili Havas Collection, FMS Archives (FMSA), Finnish National Archives (FNA), Helsinki. 
and "our small family", as she called their community, became the nucleus of a future children's home, with Mrs Margot Moses as Mutti, "the mother" and Aili Havas as "the father", as she referred to herself. The political and military atrocities in Europe had thus permanently changed the Finnish mission's agenda in Palestine.

Ever since Havas had participated in the international conference of the mission to the Jews in Vienna in 1937, she had been painfully aware of the situation of European Jews. During World War II, she focused increasingly on humanitarian efforts among the Jewish refugees in Palestine, to which the mission home with orphaned children gave an impetus. In the post-war years it was only natural to continue relief work when Jewish migration to Palestine continued and intensified after Israeli independence. In 1946 Havas came into contact with a Jewish refugee woman who had converted to Roman Catholicism and who told Havas about her young nephew's fate. The boy's parents (also converted Jews) had died and the aunt wished to bring the boy to Palestine. "The boy is just the kind of child I hope I could help. Pray for little Peter", Havas wrote in her letter..$^{10}$ In the same manner she gave a vivid description of the need for humanitarian work among the Jewish refugees, the children in particular. Rafael, one of the first children in the Finnish mission's small home school run by Havas, was "a malnourished, nice boy" and his father, a converted Jew, paid for his son's upkeep, even though he was "poor and ailing". 11 The following year, Rafael's younger siblings, Lea and Ora, came to the mission home. "For the youngest we arranged a place in an orphanage in Beth-Jala. At the very first instance, I took scissors and cut Ora's [2.5 years] and Lea's [ 5 years] hair for they were full of vermin. In a few days they were like new: did not act up but ate peacefully and obeyed." Both children were underdeveloped, including in terms of speech development, and Ora had suffered from polio, Lea from dysentery. "Pray for these poor little ones. Their parents are converted Jews but the mother is unable to care for them. Poverty is devastating", wrote Havas to her circle of mission friends and supporters in Finland. ${ }^{12}$

10 Aili Havas to Rauha Moisio [no date] (1946). Folder 15, Aili Havas Collection, FMSA, FNA, Helsinki.

11 Havas also reported that the parents paid for their children's upkeep, but in case of sickness and unemployment the payments were not required. Aili Havas to Mission director Tuure Vapaavuori, Jerusalem (November 3, 1945). Folder 15, Aili Havas Collection, FMSA, FNA, Helsinki.

12 Rauha Moisio cites Aili Havas' circular letter [probably in spring 1946]. Rauha Moisio to mission friends, Helsinki [no date] (1946). Folder 15, Aili Havas Collection, FMSA, FNA, Helsinki. 
Humanitarian work did not stop Havas from working among the adult Jews and among those who had converted to Christianity. She was invited to act as the chairperson of the Jerusalem section of the Hebrew Christian Alliance, the association of converted Jews. As a goy, a foreigner, she was apparently trusted as a neutral figure in this group of Jews who had converted to Christianity and were somewhat conflicted within themselves. In a vulnerable position herself, coming from Finland, an enemy of the Allied powers and at war with the Soviet Union, ${ }^{13}$ British Mandate officials placed Havas under surveillance, her correspondence was censored ${ }^{14}$ and transfer of funds from Finland cut off. ${ }^{15}$

In order to develop the mission work and the Christian presence in Palestine Havas came up with an ambitious plan in 1943-1944: The Nordic missions could join forces and establish a Christian Hebrew Centre in Jerusalem. ${ }^{16}$ It would have included several homes for Jewish refugee children with missionary women as their "mothers", a Christian school with Hebrew as the main language of education and a scientific centre for the study of Judaism, along the model of the Delitzschianum in Leipzig where Havas had visited on her way to Palestine in 1931. She worked hard to realize the plan and to convince the Swedish missions in Palestine and their respective organizations at home about the project. Some of the Scottish and English missionaries supported the idea, and the Swedish Israel mission's director even visited Helsinki to discuss the plan with the FELM leaders. To Havas' disappointment, nothing came out of the co-operation. Instead, she began a home school for the children at the mission home and later a kindergarten when her first Finnish co-worker, Rauha Moisio, finally reached Jerusalem in $1946 .{ }^{17}$

Even though the Finnish missionaries focused on Jews - which is very explicit in their published writings - they were familiar with other missions and

13 Finland fought against the Soviet Union first in the Winter War, 1939-1940, and again from 1941 to 1944 as an ally of Germany. See e.g. Tiina Kinnunen and Ville Kivimäki, eds., Finland in World War II: History, Memory, Interpretations (Leiden: Brill, 2011).

14 Since Havas was the only Finnish-speaking individual in Palestine, she was called to inspect her own correspondence. Soon the mandate officials realized that censorship was useless in Havas' case. The letters did not, however, travel well between Finland and Palestine, and Havas had to write to FELM via Swedish mission organizations.

15 Seija Jalagin, "Transnationalising Education for the Benefit of the Nation: Finnish Mission to the Jews in post-World War II Jerusalem," in Transnational and Historical Perspectives on Global Health, Welfare and Humanitarianism, eds. Ellen Fleischmann, Sonya Grypma, Michael Marten, and Inger Marie Okkenhaug (Kristiansand: Portal Forlag, 2013), 182-2O7.

16 For a more detailed analysis on the plan, see Seija Jalagin, "A Nordic Hebrew Christian Centre in Jerusalem?" Scandinavian Journal of History 40, no. 3 (2015): 455-477, https://doi .org/10.108o/03468755.2015.1039058. Jalagin, "Nordic." 
individual missionaries in Palestine, including those who worked among the Arabs, or among both the Arabs and the Jews. For example, Miss Lawrence and Miss Hannah Hurnard, who toured Palestine with Hurnard's car and tried to visit all the Jewish colonies and Arab villages, are among the missionary friends that Havas describes in her memoir. So is the Danish-Norwegian couple, Eli and Karen Bøgh, ${ }^{18}$ who had come to Palestine in 1938 from Denmark as independent missionaries. With the Bøgh couple, Havas shared similar ideas about living as exemplary Christians among the Jews. And as Michael Marten writes in his article in this volume, this became a typical strategy for many Western church traditions in Palestine where "attempts to generate conversions were remarkably unsuccessful"..$^{19}$ Inger Marie Okkenhaug has also pointed to this strategy, "the embassy role" by some British missionary schools, such as the Anglican Church affiliated St Mary's Home and school for Jewish girls in Jerusalem. Contrary to the mission schools of British origin that relied on English as the uniting linguistic medium, particularly in multinational schools that took Jewish, Muslim and Christian students, ${ }^{20}$ Havas and the Bøghs nurtured the Hebrew language as the uniting force for the diverse groups of Jews that were migrating to Palestine. ${ }^{21}$ Another independent missionary, the Finnish Elna Stenius, who lived on meagre support from a British mission, settled in the Finnish mission house in the wwII years. Havas writes how Stenius strolled in the streets of Jerusalem to disseminate religious leaflets

rain or shine and discussed with people. Sometimes a bunch of boys, who shouted and mocked her and would not leave her alone [...]. Such street proselytizing was heavily criticized by other missionaries. They did not think it was suitable for the value of the gospel, particularly when Elna sometimes threw her leaflets in the middle of the people or forced them to listen to what she had to say. [...] Extremely competent in lan-

18 Havas, Työkenttäni Israel, 218-220.

19 Marten in this volume.

20 Inger Marie Okkenhaug, "Education, Culture and Civilization: Anglican Missionary Women in Palestine," in The Christian Communities of Jerusalem and the Holy Land, ed. Anthony O'Mahony (Cardiff: University of Wales Press, 2003), 175-181, 192-196.

21 Eli and Karen Bøgh had met when they had both worked in India as missionaries. Karen (1904-1989) was born in Bergen, Norway and trained as a nurse and a teacher, whereas Eli (1893-1981) was a civil engineer. They married in 1932 and returned to Denmark. Their work in Palestine and Israel in 1938-1972, is described in more detail by Bodil F. Skjøtt, "Eli and Karen Bøgh-Bible Missionaries in Israel," Mishkan: A Forum on the Gospel and the Jewish People 41 (2004):38-48, http://www.caspari.com/wp-content/uploads/2016/o6/ mishkan41.pdf. 
guages, she could converse with anyone. Besides Finnish and Swedish, she spoke fluent English, French, Italian, Spanish, Arabic, even quite good German and satisfactory Hebrew. For myself, Elna Stenius has been a vivid sermon of loyalty and endurance and self-sacrificing love in God's work. $^{22}$

An important missionary figure and a powerful example to Aili Havas was the Swedish missionary, Signe Ekblad, the director of the Swedish School for Arab children in Jerusalem from 1922 to 1948 . The school was run by the Swedish Jerusalem Society, a High Church organization with powerful supporters in Sweden. Ekblad was in close contact with the British Mandate authorities, and similar to many British missionaries, pro-Arab. ${ }^{23}$ After all, the Arabs were the allies of the mandate rulers, while the British tried to maintain the ethnic and political status quo in Palestine. Following the Arab protests of 1936-1939 against Jewish immigration and land acquisitions in Palestine, the British government issued a white paper in 1939 that restricted Jewish immigration to 75 ,0oo for the coming five years. ${ }^{24}$

On her return to Palestine in 1940, Havas observed the change in atmosphere. While on holiday in the vicinity of Bethlehem she

noticed the change in the Arab population. They now seemed happy and free, the sullen face of the restless time [in 1936-1937] was gone. After all, England had promised them what they wanted. The Jews are also quiet, even though the white paper crushed their national aspirations. They know that only the victory of England can save them from Hitler. It is difficult to say how reliable the "friendship" of the Arabs will be. ${ }^{25}$

At the monthly receptions at the Swedish School, Ekblad intended for the invited people from "different circles, denominations, and nationalities to exchange ideas and acquaint themselves with one another in amity". On these occasions "one could meet a Jewish academic or medical doctor, Arabic teach-

22 Havas, Työkenttäni Israel, 206-208.

23 Inger Marie Okkenhaug, "Children, Women and Welfare in Jerusalem: A Swede in Jerusalem; Signe Ekblad and the Swedish School 1922-1948," in En svenska i Jerusalem: Signe Ekblad och den svenska skolan 1922-1948 (Betlehem: Diyar Publishing; Svenska Jerusalemsföreningen/Swedish Jerusalem Society, 2012).

24 Colin Shindler, A History of Modern Israel, 4th printing (Cambridge: Cambridge University Press, 2011), 37.

25 Aili Havas' circular letter, Bet-Jala [Beth Jala or Beit Jala] (August 20, 1940). Folder 15, Aili Havas Collection, FMSA, FNA. 
ers and administrators, representatives of the English Mandate, missionaries from different denominations, German deaconesses, and Jewish social workers", wrote Aili Havas in her memoir. ${ }^{26}$ Despite such influences, Havas was more inclined to associate with the Jews. She was carving out her "own Jerusalem", much like the leader of the American Colony, Bertha Spafford Vester, was doing, as Heleen Murre-van den Berg writes about Vester's inclination to distance herself from the Palestinian Christians among the different Christian communities in Mandatory Palestine. ${ }^{27}$ For the Finnish mission, Signe Ekblad eventually became a missionary friend in need. She helped Havas when the British authorities intended to arrest her during WwII. In 1948, when Ekblad was forced to close the Swedish School and leave Israel, she gave the rest of the food supplies to the Finnish mission so that the children and adults could survive the violence and siege during the war between Israel and the Arab states. ${ }^{28}$

When the War of Independence (as Israel calls it) or the Nakba ("the catastrophe", as the Arabs call it) ended in 1949, Havas, Moisio and their local coworkers settled in Israel to stabilize their work in Jerusalem. By 1958, the institution hosted a home for almost 5 o children between the ages 3 and 15 , and the premises consisted of several buildings to accommodate children and adults, kindergarten and school under the name Shalhevetyah, "Flame of God". ${ }^{29}$ As the work expanded, it gained a foothold, even though the Israeli authorities never gave official accreditation to the school. The graduates, however, passed the government-regulated curriculum (with additional Christian classes) and could pursue higher education. The Finnish missionaries put their energy wholeheartedly into bringing up the Jewish children as Christians. They also supported the construction of the Jewish state of Israel.

In 1947, in the FELM Christmas magazine Tulkoon valtakuntasi ("Thy kingdom come") Havas reflected on the influence of the Jews in Palestine as well as the change in their mentality. While the newspapers in the Western world reported on violent attacks, bombs, and explosions, the Hebrew newspapers

\footnotetext{
26 Havas, Työkenttäni Israel, 128.

27 Heleen Murre-van den Berg, “'Our Jerusalem': Bertha Spafford Vester and Christianity in Palestine during the British Mandate," in Britain, Palestine and Empire: The Mandate Years, ed. Rory Miller (Farnham, Surrey: Routledge, 2010).

28 Havas, Työkenttäni Israel.

29 Havas, Työkenttäni Israel, 274.
} 
in "Eretz Israel (= Palestine)" wrote about new agricultural colonies, the transformation of malaria-contaminated wetland into fertile fields. Described by Havas, the economic activities of the Jews seem superb. She also uses the phrase "Eretz Israel", the "land of Israel", as was common to those whose aim was to portray the region as the biblical promised homeland of the chosen people, identical to the Jewish nation-state of Israel. According to Israeli historian Shlomo Sand, this resulted in eliminating Palestine as the name of the geographical region and as the home of Arabs in the area. ${ }^{30}$

While rejoicing in the success of the Jews in building their own nation-state, Havas also expressed deep concern of violent nationalism:

In the early 1930s the Zionist young people still said that Zionism is a peaceful movement that with its moral force and energy will conquer the land, and that a Jew could never kill another human being.- - The present young generation says: The moral level of Europe is so low that only bloodshed and fear of a new war can affect it. We must show that we can also fight with a gun in our hand, that we can be dangerous!

According to Havas, the armed underground organizations were extremely dangerous to the morals and inner life of the people because they threatened "to ruin all that the people of Israel had built in Palestine through great sacrifice". ${ }^{31}$ Similar to Havas, teachers in the British mission schools regarded nationalism as a threat to the stability of Mandatory Palestine society. Maria Småberg has shown that the teachers spoke of it as false nationalism that threatened both the missions' "spiritual solution" as well as their promotion of unity in Palestine. ${ }^{32}$ In general, whilst admiring, as Marten states in this volume, "the Zionist colonizers in modernizing agriculture and economy [...] the missionaries would have preferred the local Palestinian population to have adopted their version of European modernity". ${ }^{33}$

Havas, for her part, writing after the mandate era, during the first years of the State of Israel, was very pro-Jewish nation. She expresses nothing of the

$30 \quad$ For an analysis of the significance of naming the area, see Shlomo Sand, The Invention of the Land of Israel: From Holy Land to Homeland, transl. Geremy Forman (London: Verso, 2013).

31 Aili Havas, "Nähtyä ja elettyä Raamatun maasta," Tulkoon valtakuntasi. Suomen Lähetysseuran joululehti (1947) [Thy kingdom come. Christmas magazine of FE LM (1947)].

32 Maria Småberg, Ambivalent Friendship: Anglican Conflict Handling and Education for Peace in Jerusalem 1920-1948 (Lund: Lund University, 2005), 390-391.

33 Marten in this volume. 
idea of unity between different national and religious groups that the British missionaries had considered central just a few years earlier.

In 1949, in the first issue of Karmel, a magazine published by the Finnish Karmel association that had Christian Zionist ideas about the Israeli State and Jews as the chosen people of God, Havas focused on the right of the Jews to live in Palestine together with the Arabs, and on patriotism and nationalism as potentially destructive ideologies that alienated people from God. When considering the demands of both the Arabs and the Jews in Palestine, Havas positioned herself as someone from another small nation "that had almost from generation to generation had to fight for its life and existence" and she could thus relate to "the fate and problems of other small nations, which I can see from inside." She could feel in her heart what "an educated Arab felt when seeing foreign people settle in the mountains and valleys that his own people had considered their own for centuries." However, Havas herself could relate even more to "the people of Judea who had for centuries and millennia kept in their heart the vision of returning to the promised land, of uniting the people in the diaspora and elevating it to its former place". ${ }^{34}$

According to Havas, both the "colourful population of Palestine" as well as the Jews, "whose mental bond to the Holy Land had never broken" and who "had no other place in this evil world" had the right to inhabit Palestine. There was so much land that had the Jews not settled there, some other people would have, and, according to Havas, Arabs, and Jews could have more amiable relations than Arabs and any European people, for example. Nonetheless, overt nationalist feelings should be kept in control, even though "love for one's people and fatherland" was required in order for people to be able to love other peoples. "Natural feeling of nationalism and patriotism include a lot of selfishness and pride" that had caused wars and oppression of the weak. To fight that, Havas, who confessed to having herself earlier made God the humble servant of Finnish nationalism, propagated the idea that Christians should regard themselves as strangers on earth. This did not refer to cosmopolitanism, however, which for Havas was only the highest form of selfishness and a mask for moral decline. $^{35}$

For Havas Jews came first, but she was optimistic that there was room for Arabs as well in Palestine. She was sympathetic to the Arabs, even those who took up arms when they realized that the Jews had come to Palestine to build a national homeland there instead of "living as guests like among other

34 Aili Havas, "Kansa ja Usko," Karmel, näytenumero (1949) [Karmel, first issue (1949)].

35 Aili Havas, "Kansa ja Usko," Karmel, näytenumero (1949). 
peoples". ${ }^{36}$ She felt that "the Jews had a higher cause on their side" even though she "had often asked herself which of the two to stand for". The "so-called Palestinian Arabs were a mixed people who spoke Arabic" and who had also "Jewish and crusader and other conqueror blood in them". In addition, the land inhabited by the Arabic speaking peoples was "incredibly wide and sparsely populated". Jerusalem was religiously sacred for the Muslims, too, but Havas regarded this a result of a false legend of Mohammed's steed. The real religious centre of the Muslims, according to Havas, was Mecca, not Jerusalem. ${ }^{37}$

"Whereas the Arabs had Syria, Lebanon, Iraq, Jordan, Arabia, and Egyptfor the Jews Israel was the only land where they could be masters in their own house, and even this land was sadly reduced." For the Jews it was " 'een bereraa', there is no other choice, there is no other place they could go". Jordan and Syria could instead welcome the Palestinian Arab refugees. Polemically she continued: "Must the national aspirations of the Arabs be filled 100\% but those of the Jews not at all!"38

Havas argued for the right of the Jews to build their national homeland in Palestine/Israel with the historical bond between the Jews and the Holy Land, as narrated in the Old Testament and reinforced by Jewish cultural traditions. ${ }^{39}$ She also praised the Jews for their vigour in developing Palestine economically, unlike the Arabs who lived in poverty or at least were not cultivating the land or advancing industry. ${ }^{40}$

As James Renton has pointed out, the British Middle East specialist in the early 2oth century did not consider the Arab population a single community but rather "viewed [them] in racial terms as a mixed, and therefore degenerate, bunch of peoples". The Balfour declaration of 1917 echoes this in its phrase of "non-Jewish communities in Palestine" which made the Arab question a minority issue while the British Mandate rulers treated the Jews as a national community, ${ }^{41}$ much the same way that Havas reasoned in 1949.

${ }_{36}$ Aili Havas, "Ajatuksia ja kokemuksia 20 vuoden varrelta Israelin keskuudessa," Suomen Lähetyssanomia 2 (1953).

37 Ibid.

38 Aili Havas, "Israel ja arabit," Suomen Lähetyssanomia 3 (1953).

39 Aili Havas, "Juutalaiset ja Erez Israel," Suomen Lähetyssanomia 6 (1953).

40 Ibid.

41 James Renton, "Flawed Foundations: The Balfour Declaration and the Palestine Mandate," in Britain, Palestine and Empire: The Mandate Years, ed. Rory Miller (Farnham, Surrey: Routledge, 2010), 22-23, 37; and also Motti Golani, "Palestine, 1945-1948: A View from the High Commissioner's Office" in the same volume, 182. 
The missionaries in Israel faced the evolving Jewish nationalism in the building of a Jewish state as well as their own otherness as Christian Europeans who were responsible for the Holocaust, the killing of 6 million Jews in the Nazi concentration camps.

In 1951, Rauha Moisio titled her article in the FELM magazine, Suomen Lähetyssanomia, "The debt of Christians to Israel" to discuss the responsibility of Finns as a Christian people and as individuals to "the heathens and the Israelis". The aim was, as has been typical for mission publicity efforts, to solicit spiritual and financial support for the mission, but also to illuminate the circumstances in Israel. The missions and missionaries as well as the Christian Jews in Israel had been criticized for not "participating in the war of independence". According to Moisio, many missions withdrew from Israel when the British Mandate ended in May 1948, but some stayed and gave shelter to the homeless, and provided medical care and spiritual support. The Finnish mission took care of 15 Jewish children and some families who had lost their homes in bombings. In addition to the sense of shared guilt for the Holocaust, the missionaries faced accusations of not supporting the fight for freedom of the Jews in Palestine. For Moisio, the independence of Israel, "the constant flow of the Israelis by ships and planes to their own land [...] 8 oo to 1,500 per day in 1949", was, by Christian Zionist ideals, proof of how "the Lord has now clearly shown that He is moving forward. The State of Israel is a fact".42 Havas recognized the challenge that the diverse Jewish groups posed to the unity of the nation and therefore supported wholeheartedly the emphasis on Hebrew as the unifying force. ${ }^{43}$ That is why the Shalhevetyah Christian School for Jewish children used Hebrew as its primary language, and that is how it also actively participated in the construction of the Jewish nation and state in Israel. As the population of Israel in the early 1950s doubled with the flow of Jewish immigrants from the

42 Rauha Moisio, “Kristittyjen velka Israelille," Suomen Lähetyssanomia 2 (1951).

43 The revival of Hebrew, the ancient religious language of Judaism, was one of the major victories of Zionism, but it was a long process in Palestine. At the end of the 19th century, French was the language of instruction in many schools. Some proponents campaigned for Hebrew to become the primary language of education and for Jews to replace their diaspora names with Hebrew names, which Beilin calls the "stubborn war for the Hebrew language" and a way of beginning a new life in Palestine and a separation from one's past life in the diaspora. This echoed the understanding of history that aimed to reintegrate Jews in Palestine with ancient history and erase the intervening centuries. Yossi Beilin, Israel: A Concise Political History (New York: St Martin's Press, 1992), 132135 . 
Middle East, Africa, and Europe, the Israeli government aspired to indoctrinate and assimilate the new-comers, through education and military service, in particular. ${ }^{44}$

The article by Moisio also indicates the difficulties of the Christian missionary agenda, even though their civilizing mission to educate the Jewish children with Hebrew as the main language (albeit with the Christian faith also included in the curriculum) seems to have been in line with the Jewish nation-building efforts. On one hand, they relied on their strategy to live as exemplary Christians and on the other hand, they needed to respect the authority of the Israeli government. Spiritually this was not difficult, because they could regard the Israeli state as the embodiment of God's plan for his own people, as Rauha Moisio wrote, and, as Aili Havas had noted, it reminded them of the Finnish people's fight for their freedom from Russian rule and towards an independent state in 1917. Even the Finnish Civil War in 1918 resonated with the experiences of the two missionaries in Israel in $1948-1949 .{ }^{45}$

Conversely, it meant that the Arabs were the invisible others to the Finnish missionaries. In fact, not much attention was paid to the Arabs because the Jews, with their history and fate in the Holocaust, came first. Moisio illustrated this vividly:

Indeed, we feel helpless and lack strength in all possible ways in front of this great task. In Israel, it is not possible to meet a European Jew who has not lost a relative in concentrations camps. It was agonising to watch the funeral convoy in the streets of Jerusalem where the ashes of 30 nameless victims of concentration camps had been flown from Austria to Tel Aviv and further taken by hearse to the soil of their fatherland. ${ }^{46}$

The missionary texts in the FELM magazine no doubt give a somewhat biased view of the missionaries' reality in Israel. They mostly wrote about the Jews because they worked to missionize them, and the supporters at home par-

\footnotetext{
44 Ari Ariel, "Ethnic Diversity in Israel," in The Wiley-Blackwell History ofJews and Judaism, ed. Alan T. Levenson (Oxford: Blackwell, 2012), 587-588, https://doi.org/10.1002/9781118232897 .ch34.

45 Seija Jalagin, “Vieraalla maalla kaukana: Aili Havaksen transnationaali elämä," in Historiallinen elämä: Biografia ja historiantutkimus, eds. Heini Hakosalo, Seija Jalagin, Marianne Junila, and Heidi Kurvinen (Helsinki: SKs, 2014). 
ticularly wanted to donate to evangelizing the Jews regardless of its meagre success. ${ }^{47}$ In fact, the missionary presence in Israel, or more likely in the imagined "Land of Israel", was more important than the actual number of conversions.

In an article in 1950, Havas described the hardships of the previous year and the struggles of the Israeli government to overcome them. Peace treaties with neighbouring Arab countries had been settled but the future of divided Jerusalem remained unresolved. Unemployment, housing problems, a shortage of teachers and nurses, and health issues were the biggest concerns after the rapid rise in population due to immigration. The will to defend the country was strong and Havas continued that

should the Arabs start to cause trouble, the Israelis could at any time occupy all of Jerusalem, not to mention the whole of Palestine on the west bank of Jordan. But the people wish to remain in peace.

Spiritual awakening was non-existent, as was religious freedom in the Finnish sense, even though the missionaries could operate freely. Among those converted Jews who were openly Christian, Havas witnessed separatist activity: "they want to break free of all organized church bodies and missions, which they openly criticize and consider foreign elements". According to Havas, the social position of the converted Jews was very difficult. Finding employment was extremely hard. ${ }^{48}$ The construction of the Jewish national project that the Finnish missionaries admired and that they paralleled with the building of their own country in the 1920s was a double-edged sword, as it alienated converted Jews from the international Christian communities. ${ }^{49}$

The published texts and correspondence of the Finnish missionaries in Palestine/Israel in the 1940s and early 1950s demonstrates how pro-Jewish and pro-

47 During the first ten years of the independent Israeli state, only two people had been baptized by the Finnish missionaries. Swanström, From Failed Mission to Apocalyptic Admiration, 87 .

48 Aili Havas, "Miekalla ja muurilastalla," Suomen Lähetyssanomia 4 (1950).

49 The Bøghs also paid attention to similar tendencies, while understanding the young Christian Jews' need for independence. Skjøtt, "Eli and Karen Bøgh," 47. 
Israel they were. Observing the political and social development in the region, they advocated an idea (and interpretation of history) that Palestine formed the historical "homeland" of the Jews, who had maintained a bond with the Holy Land since the times of the Old Testament. The end of the Jewish diaspora would thus indicate the second coming of Christ on earth and fulfil the hopes of ardent Christians. Not even the destruction of 6 million Jews in the Holocaust made these Christians cease proselytizing the Jews and reconsider the supremacy of their Christian message. On the contrary, Aili Havas maintained that it was possible to be both an ethnic Jew and a devoted Christian, and to adhere to Jewish cultural traditions as well as the Christian faith and its rituals. Likewise, the missionaries' understanding of history was theologically grounded, which left the question of the Arabs' rights to live in Palestine open to other historical and political interpretations.

Aili Havas considered the right of the Arab population to live in Palestine from both religious and ethnic viewpoints. Religiously Jerusalem was the most critical point of conflict, but Arabs should instead give way to the Jews, since Mecca was the centre of the Muslim faith. Ethnically Havas undermined the Arabs by portraying them as a mixed people (yet offered no explanation to this view), whereas the Jews, despite their diverse backgrounds and cultural mixture from African, Middle Eastern, and European countries, were God's chosen people, who could unite with one language, Hebrew, and a strong state that oversaw the building of the Jewish national home. Havas and Moisio admired the Jews beyond all others because of their technological prowess and moral stamina in transforming Palestine into an economic success story and fighting for their independence against the Arab states, and finally also working to solve the problems caused by mass immigration. According to their argumentation, this reduced the majority of the Palestinian Arabs, living in refugee camps from 1948 onwards, into a practical problem that the neighbouring Arab states could solve, should they choose to take on the responsibility.

It is possible to explain the Finnish missionaries' religiously motivated political ideology with their nationalistic understanding - and indeed, experiences-of the developments in Finland since 1917. First, Finland had been under the rule of the Kingdom of Sweden for almost 700 years, from the mid12th century to 1809, and thereafter under the rule of the Czar of Russia as an autonomous grand duchy. Following the late 19th-century "national romantic" construction of Finland, the national narrative contained an idea of a homogenous people with ethnic, linguistic, and religious unity. But it also contained violence. The Finns paid a price for their independence, first in the Civil War of 1918 and then in the Winter War of 1939-1940 and Continuation War of 1941- 
1944 against the Soviet Union. ${ }^{50}$ Almost 100,ooo lives (2.6\% of the population) and $10 \%$ of Finnish territory were sacrificed for the nation's continued existence.

Even though Havas warned about overt nationalism, she had internalised the nation-state ideology that highlighted the right of every nation to a state of its own. On the other hand, the nation-state ideal also stood in contrast to the transnationality in missionary lives that, in general, consisted of crossing national, cultural, and state borders, settling in a foreign country as immigrants and using many different languages in diverse social and ethnic settings. Nonetheless, the national and the transnational seemed to find their place in one person and in a single missionary context. This demonstrates the adaptability and transferability of patriotism (if not nationalism) and the nation-state ideology.

It is more difficult to explain how the Finnish missionaries could close their eyes to the fate of the Arab refugees, particularly when their own work was based on humanitarian ideals. The Finnish missionaries moved from relief work to social and educational work in order to aid the Jewish holocaust refugees and vulnerable immigrant families in Jerusalem. They were also familiar with the humanitarian efforts of, for example, the Swedish missionary, Signe Ekblad, who organized food kitchens for the poor Arab families in the old city of Jerusalem in the $1930{ }^{5 .}{ }^{51} \mathrm{In}$ fact, in the preface to her autobiographical book of the mission in Palestine/Israel in 1958, Aili Havas wrote that "someone who had lived among the Arabs would maybe see many things differently" compared to herself, who had "lived among the Jews for 26 years". 52 This reads as only a modest note in a book that Havas had been commissioned to write in order to celebrate the 1ooth anniversary of FELM and describe the Finnish mission to the Jews in Palestine/Israel. On the other hand, her words also read as if someone living in Palestine/Israel was compelled to take sides. Although the private and published texts by Aili Havas give an insightful and enlightened view of the changing political, social, and religious circumstances in the region, they also suggest spiritual hopefulness, if not even strong belief, in the "homeland" of the Jews, "Eretz Israel", as a sign of Christ's Second Coming, much like the Christian Zionists articulated.

$5^{\circ}$ Interestingly, Finnish World War II history contains three wars with specific names. In addition to the Winter War and Continuation War against the Soviet Union, there is the Lapland War against the German troops in Finland, Finland's former allies, from October 1944 to April 1945 .

$5^{1} \quad$ Okkenhaug, "Children," 95.

$5^{2}$ Havas, Työkenttäni Israel, 6. 
Nonetheless, there remains an uneasy feeling about the depth of analysis at this level. Does religious conviction mean that an individual is likely to close her/his eyes to the prevailing social reality? In the case of Aili Havas, and possibly the other Finnish missionaries as well, this seems questionable. As we have seen, Havas reasoned that the Palestinian Arabs could find a home in the surrounding Arab countries, whereas living side by side with Jews was clearly not an option. The Jews deserved a state of their own and ethnic diversity was not an ideal solution. The nation-state ideal with one nation and preferably one language - be it Finnish in Finland or Hebrew in Israelwas the internalized order of nation-states for Havas. Population exchanges were also employed to solve ethno-political dilemmas, particularly in evolving states. They had already been tested in resolving the legacy of the Ottoman Empire, notably with Turkey and Greece exchanging 1.6 million people altogether. This model was later adapted in the partition of British India in 1947 into the independent states of India and Pakistan. Havas could also relate to the contemporary history of Finland for examples of population transfers in the name of a greater cause or necessity. At the end of the Civil War in 1918, some 10,00o Reds (left-wing fighters and their families) fled or moved to Soviet Russia, in fear of being imprisoned or executed, and conversely, more than 11,000 East Karelians from Russia fled to Finland after an unsuccessful revolt against Bolshevik rule in 1921-1922. During World War II, the Finnish government ordered more than 430 ,ooo Finns, $10 \%$ of the entire population, to move from their homes in Karelia, Salla, Kuusamo, and Petsamo, which were ceded to the Soviet Union according to the Moscow Armistice of September 1944 (which eventually also led to the Lapland War against the former allies of Finland, the German troops that had to be expelled from Finland). ${ }^{53}$ Thus, even though Havas had by 1958, and the publication of her account of the Finnish mission in Palestine/Israel, lived in Jerusalem for almost 30 years, the formative ideas of Havas and the other Finnish missionaries derived from the national historical narrative they had adopted as citizens of the emerging Finnish nationstate.

The pro-Jewish agenda of the Finnish missionaries eventually ended in the late 196os at the eve of Aili Havas' retirement. After the Six-Day War of 1967, the Finnish missionaries were more inclined to see things from the Arab point of view. At this point, enrolling Jewish children into Christian boarding schools became impossible because of new legislation. The Shalhevetyah School was 
forced to find new students. ${ }^{54}$ Soon it was full of Arab Christian children, which completely changed the agenda of the Finnish mission. ${ }^{55}$

\section{Bibliography}

Aili Havas Collection, FMS Archives (FMSA). Finnish National Archives (FNA), Helsinki.

Ariel, Ari. "Ethnic Diversity in Israel." In The Wiley-Blackwell History ofJews andJudaism, edited by Alan T. Levenson. Oxford: Blackwell, 2012.

Golani, Motti. "Palestine, 1945-1948: A View from the High Commissioner's Office." In Britain, Palestine and Empire: The Mandate Years, edited by Rory Miller, 177-187. Farnham, Surrey: Routledge, 2010.

Havas, Aili. Työkenttäni Israel. Helsinki: Suomen Lähetysseura, 1958.

Jalagin, Seija. "Transnationalising Education for the Benefit of the Nation: Finnish Mission to the Jews in post-World War II Jerusalem." In Transnational and Historical Perspectives on Global Health, Welfare and Humanitarianism, edited by Ellen Fleischmann, Sonya Grypma, Michael Marten, and Inger Marie Okkenhaug, 182207. Kristiansand: Portal Forlag, 2013.

Jalagin, Seija. “Vieraalla maalla kaukana: Aili Havaksen transnationaali elämä.” In Historiallinen elämä: Biografia ja historiantutkimus, edited by Heini Hakosalo, Seija Jalagin, Marianne Junila, and Heidi Kurvinen, 113-131. Historiallinen arkisto 141. Helsinki: SKS, 2014.

Jalagin, Seija. “A Nordic Hebrew Christian Centre in Jerusalem? Relief work, Education and Nordic Neutrality in Palestine, 1943-1946." In "Mission, Relief and Development: Gender and Nordic Missions in Transnational and Humanitarian Settings, ca. 189o196o," edited by Seija Jalagin, Inger Marie Okkenhaug, and Maria Småberg. Special Issue, Scandinavian Journal of History 40, no. 3 (2015): 455-477. https://doi.org/10 .1080/03468755.2015.1039058.

Johnson, Corey, and Amanda Coleman. "The Internal Other: Exploring the Dialectical Relationship Between Regional Exclusion and the Construction of National Identity." Annals of The Association of American Geographers 102, no. 1 (2012): 863-88o. doi:10.108o/0oo456o8.2011.6o2934.

Kinnunen, Tiina, and Ville Kivimäki, eds., Finland in World War II: History, Memory, Interpretations. Leiden: Brill, 2013.

Murre-van den Berg, Heleen. “'Our Jerusalem': Bertha Spafford Vester and Christianity

54 Swanström, From Failed Mission to Apocalyptic Admiration, 121.

55 Jalagin, "Transnationalising." 
in Palestine during the British Mandate." In Britain, Palestine and Empire: The Mandate Years, edited by Rory Miller, 67-83. Farnham, Surrey: Routledge, 2010.

Okkenhaug, Inger Marie. "Education, Culture and Civilization: Anglican Missionary Women in Palestine." In The Christian Communities of Jerusalem and the Holy Land: Studies in History, Religion and Politics, edited by A. O'Mahony, 171-199. Cardiff: University of Wales Press, 2003.

Okkenhaug, Inger Marie. "Children, Women and Welfare in Jerusalem." In A Swede in Jerusalem: Signe Ekblad and the Swedish School 1922-1948. En svenska i Jerusalem. Signe Ekblad och den svenska skolan 1922-1948, 87-101. Bethlehem: Diyar Publishing; Svenska Jerusalemföreningen/Swedish Jerusalem Society, 2012.

O'Mahony, Anthony. "The Christian Communities of Jerusalem and the Holy Land: A Historical and Political Survey." In The Christian communities of Jerusalem and the Holy Land: Studies in History, Religion and Politics, edited by A. O'Mahony, 1-37. Cardiff: University of Wales Press, 2012.

Renton, James. "Flawed Foundations: The Balfour Declaration and the Palestine Mandate." In Britain, Palestine and Empire: The Mandate Years, edited by Rory Miller, 15-37. Farnham, Surrey: Routledge, 2010.

Saarilahti, Toivo. Sata vuotta suomalaista lähetystyötä. 1, 3, Lähetystyön läpimurto: Suomen lähetysseuran toiminta kotimaassa 1895-1913. Helsinki: Suomen Lähetysseura, 1989 .

Sand, Shlomo. The Invention of the Land of Israel. From Holy Land to Homeland. Translated by Geremy Forman. London: Verso, 2013.

Shindler, Colin. A History of Modern Israel. 4th printing. Cambridge: Cambridge University Press, 2011.

Skjøtt, Bodil F. "Eli and Karen Bøgh—Bible Missionaries in Israel." Mishkan: A Forum on the Gospel and the Jewish People 41 (2004): 38-48. http://www.caspari.com/wp -content/uploads/2016/o6/mishkan41.pdf. Accessed June 12, 2018.

Småberg, Maria. Ambivalent Friendship: Anglican Conflict Handling and Education for Peace in Jerusalem 1920-1948. Lund: Lund University, 2005.

Swanström, André. From Failed Mission to Apocalyptic Admiration: Perspectives on Finnish Christian Sionism. Åbo: Åbo Akademi, 2007.

Wallendorff, Per. Suomen lähetysseuran juutalaislähetystyön historia. Suom. Aune Krohn. Helsinki: Suomen Lähetysseura, $195^{8}$. 


\title{
Catholic Humanitarian Assistance for Palestinian Refugees: The Franciscan Casa Nova during the 1948 War
}

\author{
Maria Chiara Rioli
}

The issue of the Palestinian refugees represents one of the most complex unresolved problems in contemporary global history. The situation originated when the war for Palestine was unleashed following the United Nations resolution of November 29, 1947 that provided for the partitioning of Palestine into Jewish and Arab states. The battles between the Arab League and Israeli armies, and Tsahal's expulsions of populations of in the conquered villages and cities precipitated the flight of about 750,00o Palestinian refugees, who poured into the closest available Arab villages within the State of Israel itself, so constituting an internally displaced people. Part of the Palestinian refugee population then transited to the United States, Latin America, Europe, and other continents.

Twenty years later, the June 1967 War saw Israel defeat Egypt and annex East Jerusalem, the territory to the west of the river Jordan (the so-called "West Bank", previously under the control of the Hashemite Kingdom of Jordan), the Sinai Peninsula, the Gaza Strip, and the Golan Heights. These new acts of war caused the flight of another 300,00o Palestinians. Today, the United Nations agency created in 1949 to provide humanitarian aid to the Palestinian refugees - the United Nations Relief and Works Agency for Palestine Refugees in the Middle East (UNRWA) — registers 5 million Palestinian refugees.

Historically, the request to recognize the right of return for the Palestinian refugees has constituted one of the principal themes on which the two fronts have taken up positions around opposing interpretations and narratives. The Israeli government's refusal to recognize the right to return for refugees for reasons of security and on the grounds of its interpretation of the Palestine War as a Zionist war of defense against the Arab attack of May 15, 1948, has determined the absence of a solution. At the same time, Palestinian identity post-1948 has been redefined around the experience of refugee camps, and the national liberation movement has given the refugee question a position of central importance and has invested the refugee camps with the symbolism of lieux de mémoire, the liberation of Palestine, and resistance to the Israeli occupation. 
From the research perspective, numerous volumes have explored these issues from the perspective of sociology, anthropology, world religions, refugee law, human rights law, and humanitarian law. ${ }^{1}$ From the historiographical perspective too, the reconstruction of the Palestinian exodus and archival research on the question of military and political responsibility have opened a new page in the history of 1948. As has been noted, for several decades, the historical debate has polarized around two opposing narratives that have dominated Israeli and Arab historiographies. The one presents a nationalist pro-Zionist vision, with a weak Israel represented as the victim of an Arab attack from which it emerged unexpectedly victorious; and the other emphasizes the failure of the Arab leadership to take charge. Since the 199os, the so-called "new historians" have deconstructed myths and analytical paradigms and interpretations of the conflict, exploring archives hitherto ignored by studies, identifying the problem of the Palestinian refugees right at the point of its creation and pointing out the absence of a solution, and its persistence as the most dramatic element in the Israeli-Palestinian conflict, along with the lack of a definition for a shared arrangement with regard to Jerusalem. ${ }^{2}$

However, despite the crucial importance of these issues and the impetus provided by the work of the "new historians", there are few historical analyses on the Palestinian refugees. Innumerable questions and crucial aspects regarding the reconstruction of the complex picture of events in Palestine in 1947 that remain to be clarified and analyzed by means of the tools and methodologies of historical research and its interface with other disci-

1 In the bibliography see at least Francesca P. Albanese and Lex Takkenberg, Palestinian Refugees in International Law, 2nd rev. ed. (Oxford: Oxford University Press, 2020); Luigi Achilli, Palestinian Refugees and Identity: Nationalism, Politics and the Everyday (New York: I.B. Tauris, 2015); Susan Akram and Terry Rempel, Out of Place, Out of Time: Refugees, Rights and the Re-Making of Palestine/Israel (London: Pluto Press, 2015); Are Knudsen and Sari Hanafi, eds., Palestinian Refugees: Identity, Space and Place in the Levant (Abingdon: Routledge, 2011); Michael Dumper, ed., Palestinian Refugee Repatriation: Global Perspectives (Abingdon: Routledge, 2006).

2 Of the works by the Israeli so-called "new historians", see in particular Eugene L. Rogan and Avi Shlaim, eds., The War for Palestine: Rewriting the History of 1948, 2nd ed. (Cambridge: Cambridge University Press, 2007); Ilan Pappé, The Ethnic Cleansing of Palestine (Oxford: Oneworld, 2006); Benny Morris, The Birth of the Palestinian Refugee Problem Revisited, and ed. (Cambridge: Cambridge University Press, 2003); Avi Shlaim, The Iron Wall: Israel and the Arab World (London: Allen Lane, 200o); Ilan Pappé, The Making of the Arab-Israeli Conflict, 1947-1951 (London: I.B. Tauris, 1992); Avi Shlaim, Collusion across the Jordan:King Abdullah, the Zionist Movement, and the Partition of Palestine (New York: Columbia University Press, 1988); Simha Flapan, The Birth of Israel: Myths and Realities (New York: Pantheon, 1987). 
plines. ${ }^{3}$ The volumes by Benny Morris and other Israeli authors have contributed decisively to reopening the inquiry on these issues, but they are limited in their interpretations, especially in light of the political re-reading proposed after the failure of the Oslo peace process, which Morris himself publicized in interviews and articles, sparking an international debate that has brought to light contradictions and biases in the historical approaches of other scholars.

Aside from ideology, another element must be taken into account: that of the sources and access to them. In the case of the Palestinian refugees, the question of archives, central to any historical research, has not yet been sufficiently examined and analyzed, with the exception of a few studies. ${ }^{4}$ This is perhaps a result of the high toll of politicization - especially by the Israelis, in their effort

3 Some studies constitute exceptions, including the research of Jalal al-Husseini, Riccardo Bocco, and Kjersti Gravelsæter Berg. See Jalal al-Husseini, "Le statut des réfugiés palestiniens au Proche-Orient: Facteur de maintien ou de dissolution de l'identité nationale palestinienne," in Les Palestiniens entre Etat et diaspora: Le temps des incertitudes, eds. Jalal Al Hussein and Aude Signoles (Paris: IISMM, 2013), 67-94; Jalal al-Husseini, "The Evolution of the Palestinian Refugee Camps in Jordan: Between Logics of Exclusion and Integration," in Cities, Urban Practices and Nation-Building in Jordan, eds. Myriam Ababsa and Rami Daher (Beirut: Presses de l'Ifpo, 2011), 181-204; Jalal al-Husseini, "The Arab States and the Refugee Issue: A Retrospective View," in Israel and the Palestinian Refugees, eds. Eyal Benvenisti, Chaim Gans, and Sara Hanafi (Berlin: Springer, 2007), 436-464; Jalal al-Husseini and Riccardo Bocco, "Dynamics of Humanitarian Aid, Local and Regional Politics: The Palestine Refugees as a Case-Study," in Palestinian Refugees: Identity, Space and Place in the Levant, eds. Are Knudsen and Sari Hanafi (Abingdon: Routledge, 2011), 128-146; Riccardo Bocco and Lex Takkenberg, eds., "UnRwa and the Palestinian Refugees 6o years later," special issue, Refugee Survey Quarterly 28, nos. 2-3 (2009); Riccardo Bocco, "UnRwA and the Palestinian Refugees: A History within History," Refugee Survey Quarterly 28, nos. 2-3 (2009): 229-252; Kjersti G. Berg, "The Unending Temporary: United Nations Relief and Works Agency (UNRWA) and the Politics of Humanitarian Assistance to Palestinian Refugee Camps 1949-2012" (PhD diss., University of Bergen, 2015); Kjersti G. Berg, "From Chaos to Order and Back: The Construction of UnRWA Shelters and Camps, 1950-1970," in UNRWA and Palestinian Refugees: From Relief and Works to Human Development, eds. Sari Hanafi, Leila Hilal, and Lex Takkenberg (London: Routledge, 2014), 109-128; Kjersti G. Berg, "Gendering Refugees: The United Nations Relief and Works Agency (UnRwA) and the Politics of Relief," in Interpreting Welfare and Relief in the Middle East, Social, Economic and Political Studies of the Middle East and Asia, eds. Nefissa Naguib and Inger Marie Okkenhaug (Leiden: Brill, 2007), 149-174; Peter Gatrell, The Making of the Modern Refugee (Oxford: Oxford University Press, 2013), 118147.

4 The archival question in the research on the Palestinian refugees has been carefully considered in Salim Tamari and Elia T. Zureik, eds., Reinterpreting the Historical Record: The Uses of Palestinian Refugee Archives for Social Science Research and Policy Analysis (Jerusalem: Institute of Jerusalem Studies, 2001). 
to delegitimize the presence and operations of UNRWA -5 and, on the contrary, of the low degree of historicization that characterizes the debate on these matters. The extensive use of almost exclusively Zionist and Israeli military archives has sometimes constrained studies to a single documentary typology, and that too coming from just one of the parties involved. ${ }^{6}$

This chapter begins with a presentation of some archives-particularly ecclesiastical ones - that are still largely unpublished or have not yet been utilized by historians in studies on the Palestinian refugees. These archival reflections allow for a transition from a global overview to the local analysis of a specific case study: that of the Franciscan casa nova in Jerusalem. Originally a structure that hosted pilgrims, at the end of 1947 it became one of the places in which one of the most important institutions of the Jerusalem Church-the Franciscan Custody of the Holy Land-performed its humanitarian aid work in the "torment" of $1948 .{ }^{7}$

The identification, access, and analysis of numerous archives spread all over the world that have to do with the phenomenon of the Palestinian refugees, in different proportions and fashions, represents one of the first challenges in the revision of the current narratives and in the writing of new, historically documented studies on the history of the population in question. There are several projects underway, conducted by research centres and associations, aimed at finding and conserving documents produced by institutions or individuals, including collections of oral sources.

5 This is the case for Arlene Kushner, UNRWA Supplemental Report: A Rigorous Review of Agency Practices (Center for Near East Policy Research, 2004), available at www.israelvisit.co.il/ BehindTheNews/pdf/SecondReport.pdf; Avi Beker, UNRWA, Terror and the Refugee Conundrum: Perpetuating the Misery (Jerusalem: Institute of the World Jewish Congress, 2003); Abraham Ashkenasi, "The International Institutionalization of a Refugee Problem: The Palestinians and UNRWA," Jerusalem Journal of International Relations 12, no. 1 (199o): 45-75.

6 This is one of the arguments presented by Nur Masalha and Walidi Khalidi. See Nur Masalha, "A Critique on Benny Morris," in The Israel/Palestine Question, ed. Ilan Pappe (London: Routledge, 2003), 211-220.

7 This expression is found in reportage following the events in a magazine published by the Latin Patriarchate of Jerusalem, with particular reference to the humanitarian action mobilized for the refugee population by the Italian priest Antonio Vergani, Patriarchal Vicar for Galilee. See the article by Pierre Médebielle, "Mgr Antoine Vergani (1905-196o): In Memoriam," Jérusalem: Le Moniteur diocésain du Patriarcat latin 26, nos. 3-4 (1960): 54-61. 
At the same time, a vast amount of uninvestigated documentary material is already available within recognized archival institutions. Here, the most important archive is that of the United Nations Relief and Works Agency for Palestine Refugees in the Near East (UNRWA), the UN agency established in 1949 with the goal of assisting the Palestinian refugees. The difficulty of access and the political and economic difficulties that the UNRWA has experienced for decades have prevented a detailed cataloguing of the records and made it difficult even to discern the location and the size of its documentary and archival holdings, despite work on this front. ${ }^{8}$

Faced with the problem of consulting the UNRWA archives, important nongovernmental organizations operating in Palestine have made funds available to researchers. This has been the case, for example, with the archives of the International Committee of the Red Cross in Geneva, and funds have been dedicated to the humanitarian action of the American Friends Service Committee, whose archives are housed in the AFSC's central office in Philadelphia; ${ }^{9}$ the latter have already featured in some studies. ${ }^{10}$

This reference to the Quakers introduces a broader reflection. From the first battles in the autumn of 1947, mobilization to assist the Palestinian refugees was not only achieved by international agencies and nongovernmental organizations but also involved the complex and variegated web of Christian institutions already historically present and active in the region. Convents, schools, and hospitals operated by religious congregations or directly by the local churches of various rites and denominations were among the first places to receive and aid the Palestinian refugees. This action also contributed to a profound redefinition of the visions and strategies of humanitarian activity after 1948. ${ }^{11}$ This being the case, the ecclesiastical archives constitute a source that

8 Salim Tamari and Elia Zureik, The UNRWA Archives on Palestinian Refugees: A Feasibility Study for Policy and Applied Research; Phase 1 (Jerusalem: Institute for Palestine Studies, 1996).

9 Julie Peteet, "The Afsc Refugee Archives for Palestine 1948-1950," in Reinterpreting the Historical Record: The Uses of Palestinian Refugee Archives for Social Science Research and Policy Analysis, ed. Salim Tamari and Elia T. Zureik (Jerusalem: Institute of Jerusalem Studies, 2001), 109-128.

10 Nancy Gallagher, Quakers in the Israeli-Palestinian Conflict: The Dilemmas of NGO Humanitarian Activism (Cairo: American University in Cairo Press, 2007).

11 The categories of secular humanitarianism and humanitarian Christian — and particularly Catholic - thought cannot be superimposed and confused. The second is affected by the historical evolution of modern Catholic social doctrine. It is, however, true that in the course of the 2oth century, and particularly in consequence of certain epoch-making events - the two world wars and, from an internal point of view, the shift brought about by the Second Vatican Council in bringing the poor into the centre of the ecclesiastical 
is equally important but as yet hardly utilized in the research on these issues. Moreover, the study of the involvement of non-Christian and non-Western religious agency represents another frontier in the historiography of humanitarianism, in Palestine as elsewhere. ${ }^{12}$

In the Catholic environment, the centrality of the Holy See is also confirmed by the archives on these matters. The archives of the Pontifical Mission for Palestine (PMP) — the institution established by Pius XII in 1949 to aid the Palestinian refugees-are partially preserved in the Vatican archives, mainly in the Pius XII-era holdings of the Congregation for the Oriental Churches that were opened to scholars for the pontificate of Pius XII (1939-1958) in March 2020.13 Moreover, the plurality of the Catholic presence makes it possible to retrace many threads of inquiry in other ecclesiastical archives, in the Middle East and elsewhere. If the history of the Palestinian refugees is necessarily global and interconnected, characterized by migrations and transfers, the archives too must be researched on a broad scale.

In this discourse, Jerusalem was clearly central to the coordination of aid supply and distribution. The humanitarian machine dedicated to the Palestinian refugees suffered from the lack of a stable authority in charge of the local Church, the Latin Patriarchate. The death of Patriarch Luigi Barlassina on September 27, 1947, two months before the UN resolution and the beginning of the Palestinian-Zionist civil war, left a gap at the heart of the Latin Church due to Rome's failure to nominate a successor. The difficulty in maintaining contacts between the priests, and the transfer from Jerusalem to Amman of Gustavo Testa, the Patriarchal regent and Apostolic Delegate, because of his fear of the bombing in the Holy City, prevented the rapid deployment of an aid network. At the same time, the centrality of the Holy Land for

debate-Catholic social thought has changed in its categories and analysis from the lay version, in the adherence, for example, to the theory of human rights, albeit not without tensions and unresolved dilemmas. This paradigm shift was also favoured by the spread of humanist thought and of Catholic Personalism as formulated by philosophers and theologians, especially Jacques Maritain, and Emmanuel Mounier. See Daniele Menozzi, Chiesa e dirittiumani:Legge naturale e modernità politica dalla Rivoluzione francese ai nostrigiorni (Bologna: Il Mulino, 2012).

12 On the importance of extending the reflection about humanitarianism's moral and cultural basis beyond the Christian and Western ethics, institutions and agents, see Kevin O'Sullivan's considerations in Matthew Hilton et al., "History and Humanitarianism: A Conversation," Past \& Present 241, no. 1 (November 2018): e25-e26 (online only).

13 As announced by Pope Francis during his address to the officials of the Vatican Apostolic Archive on March 4, 2019, the Vatican archives for the pontificate of Pius XII (1939-1958) opened on March 4, 2020. 
Catholicism worldwide ensured the rapid mobilization of various groups, particularly in Europe and the United States.

From the United States, the Catholic Near East Welfare Association (CNEWA) led by Thomas McMahon requested that the Holy See establish an organization exclusively dedicated to the Palestinian refugees, the PMP. This explains why one of the most important documentary deposits is certainly that of the CNEWA, based in New York, whose archives were transferred to the archives of the Archdiocese of New York in 2018. Founded in 1926 by Pius XI with the intention of combining in a single entity various associations and initiatives committed to fundraising for the Christians of the Middle East, the CNEWA became one of the principal financers of the Congregation of the Oriental Church and, in turn, of the Latin Patriarchate and other institutions. Through an intense mobilization of various sectors of us Catholicism, in the period after the Second World War and especially during and after the battles of the 1948 Palestine War, the CNEWA raised huge sums of money for the Palestinian refugees. McMahon, one of the first foreign Catholic prelates to arrive in Israel and Jordan in 1948, also devoted his energy to proposing the formation of a Vatican agency to assist the Palestinian refugees, which was realized with the foundation of the PMP. As is the case with the archives of the CNEWA too that a detailed inventory is not currently available. However, there are dozens of boxes containing correspondence concerning the establishment of the PMP and its functioning in the following decades, including coordination with other entities and reports and statistics on the missions. A large photographic archive, also not yet organized and digitized, enriches this collection.

In Europe, private and diocesan archives, and those of episcopal conferences enable the reconstruction of the actions of clergy and laymen who were mobilized, and not just in favour of the internationalization of Jerusalem - the Holy See's proposal for the Holy City — but also to organize fundraising and aid missions during the fighting in 1948 and the following years. This is true of the archive of the orientalist Louis Massignon, who created the security committee for the Bethlehem area, and of the archive of the archdiocese of Paris, and also of the archive of the diocese of Liège, which was among the first to send volunteers and donations, focusing especially on the area of Nazareth. ${ }^{14}$

14 See the material on Louis-Joseph Kerkhofs, in particular nos. 22-24 "œuvres patronnées spécialement par l'évêque (la Palestine)" described in André Deblon, Paul Gerin, and Ludovic Pluymers, Les archives diocésaines de Liège: Inventaires des fonds modernes (Louvain: Nauwelaerts, 1978). 
Returning to Jerusalem, a holy city three times over, the archives of the Latin Patriarchate, which was re-established in 1847 and has jurisdiction over Israel, the Palestinian Territories, Jordan, and Cyprus, are housed in the diocesan seat, within the walls of the Old City, near Jaffa Gate. There is no complete inventory for them, except for a list of the binders, reorganized at the end of the pastoral mandate of Patriarch Michel Sabbah in the early part of the first decade of this century but not according to any precise scientific criteria. The list registers the name of the box, the first and last dates contained in it, and the initials of the patriarchs under whose pastoral governance that chronological period falls. By means of this research instrument, as incomplete, unreliable and poor in detail as it is, it is possible to easily identify the Patriarchal files specifically dedicated to aid for refugees, especially through the coordination between the Latin Patriarchate and the PMP. Although not immediately evident on the title on the folders, the binders also contain other documentation to do with refugee schools and statistics, from correspondence with the dicasteries of the curia, and in the files on the parishes.

One of the most important archives in the city, for the history and documentation it contains, is that of the Franciscan Custody of the Holy Land. Unlike the Patriarchal archive, this archive covers more than 800 years and possesses a detailed, three-volume inventory. ${ }^{15}$ The archive has been the object of a transfer intervention, reclassification, and description, finished in 2012, with a subsequent process to update and complete the organizing and inventorying, which is still underway. Given the vast network of parishes, convents, sanctuaries, hostels for pilgrims, and schools in which the Custody received and housed thousands of Palestinian refugees, it is striking that the documentation available today on the Palestinian refugees is not particularly conspicuous. It is probable that a good part of the documents have been lost or lie as yet undiscovered in convents or other deposits. Another portion may be contained in binders currently inaccessible due to temporal limitations. The commissariats of the Holy Land and Franciscan provinces all over the world also collected other documentation from religious in the service of the Custody, although it is difficult to establish the locations and quantities of these papers.

While this does not represent a huge amount of documentation, it does make some clarifications possible. In particular, the facts gleaned from the Franciscan casa nova in Jerusalem, which experienced a flood of refugees from

15 Andrea Maiarelli, ed., L'Archivio storico della Custodia di Terra Santa (1230-1970) (Milan: Terra Santa, 2012). 
the very first weeks of the conflict, enable us to shed light on some of the mechanisms and phenomena of the aid operations of the Catholic Church during the first Israeli-Palestinian conflict.

The events and personalities that define the events in the case nove of Palestine, and in particular of Jerusalem in 1948, belong to an unwritten story. These are events as yet unexplored in the historiography, primarily because of the fragmentary nature of the available sources, but also because of a broader historiographical gap regarding the humanitarian action set in train by the churches-including the Catholic Church — upon the outbreak of the Palestine War in the autumn of 1947.

There was not just one casa nova that received refugees during the conflict; in fact, the most notable case was that of Nazareth, which received thousands of persons fleeing from Galilee and from all over Palestine. Other sources for this story are to be found in the Custodial archives, in the archive of the General Curia of the Little Brothers at Rome ${ }^{16}$ and in the archives of the CNEWA. References to the dramatic living conditions of the refugees hosted by the casa nova of Nazareth can also be found in the correspondence of American prelates, who feared that the difficult living conditions could favour the spread of communist ideals or incentivize a transition to other Christian denominations that offered more economic aid. McMahon, the secretary of the CNEWA, wrote to Archbishop Francis Spellman in December 1948 that "the Casa Nova [in Nazareth] is full of refugees, who wanted to hoist the Commie banner over it".17

In any case, the documentation available on the Jerusalem casa nova allows for some specific reflections on the population that had moved into these places hitherto reserved for pilgrims, on the troubled relations between the refugees and the friars of the Custody, and on the phase immediately after the conclusion of the battles of 1947-1949 and the difficult effort to resettle the displaced people elsewhere.

16 See in particular the General Secretariat collection, in the files regarding the correspondence with the Custody of the Holy Land.

17 AANY, ACNEWA, McMahon to Spellman, s.l. (December 10, 1948). 


\section{From Pilgrims to Refugees: The Entangled History of the Jerusalem Casa Nova}

Historically, the Franciscan Custody was the most important institution for the reception of pilgrims who came to the region to visit the Holy Places. ${ }^{18}$ From the seventeenth century onwards, this activity led the Franciscans to open specific spaces devoted to hospitality; the so-called case nove came into existence, the first of which was built in Jerusalem, beside St Saviour's convent, the headquarters of the Franciscan Custody, followed by similar structures at Ramle, Emmaus, and Acre..$^{19}$ In 1634, the Custos, Father Paolo da Lodi, requested the permission of the Minister General of the Friars to construct a new building in which to host pilgrims, thus relieving the convent of the "calumnies" that were circulating concerning "cohabitation and excessive familiarity with various races, to the offense of religious decorum", especially as regarded women. ${ }^{20}$ A space was found in Jerusalem for this building outside the walls of the convent, both on account of the lack of available space inside, and because of the Ottoman authorities' opposition to the expansion. It was used not only to receive pilgrims but also, for example, to house friars sick with the plague so as to prevent the spread of the disease to other religious in the convent, according to some sources from the beginning of the 18th century. The casa nova was known as a place for healing the sick through the 19th century, when a proper infirmary was established.

The chronicles attest to the uninterrupted arrival of pilgrims and travelers of various nationalities, European, American, and Eastern, divided in two areas in different case nove. These were clergy and laity of various Christian

18 On the history of the Franciscan presence in Palestine, see Giuseppe Buffon, Les Franciscains en Terre Sainte (1869-1889): Religion et politique, une recherche institutionnelle (Paris: Cerf; Éditions franciscaines, 2005); Paolo Pieraccini, Cattolici di Terra Santa (1333-200o) (Florence: Pagnini, 2003); Andrea Giovannelli, La Santa Sede e la Palestina: La Custodia di Terra Santa tra la fine dell'impero ottomano e la guerra dei sei giorni (Rome: Studium, 2000).

19 See Narcyz S. Klimas, “Casa Nova di Gerusalemme: L'ospizio dei Pellegrini," Frate Francesco 81 (2015): 197-218; Narcyz S. Klimas, "Pellegrini a San Salvatore di Gerusalemme: L'ospitalità francescana," Frate Francesco 8o (2014): 96-125; Narcyz S. Klimas, "Itinerari, guide, racconti, tradizioni o abitudini dei pellegrini in Terra Santa," Antonianum 87 (2012): 93144 .

20 Memorandum from Father Fr. Paolo da Lodi to Rev. mo P. Generale of the Serafic Order, where he asks that the pilgrims no longer be hosted in our convent in Jerusalem, but rent private houses, as they have done at other times, in F. Verniero da Montepeloso, Croniche ovvero Annali di Terra Santa, III, 1632-1637, (Florence, 1930), 188-192, cited in Klimas, Casa Nova di Gerusalemme, 199. 
denominations. During the 19th century, the growing influx of visitors into an ever-more cosmopolitan Jerusalem ${ }^{21}$ made expansion necessary. Giuseppe Valerga resided there too, the first Patriarch of the newly re-established Jerusalem Latin diocese. The travellers who passed through in the course of the 19th century remarked on the grand dimensions of the structure "laid out like a convent, where there are corridors in a square with the respective rooms both for men and for women", a courtyard, two refectories capable of accommodating 400 persons, and a large terrace with a broad view of the city. A lower level was added in 1895 , with 5 o rooms, adding to the existing 116. The following year, 527 pilgrims were accommodated. The travelers could stay for a maximum of 15 days; in that year, there were 6,326 days of occupancy.

Over the decades, it hosted sovereigns and princes, intellectuals and simple pilgrims. The livre d'or with the signatures of guests of the casa nova attests to the variety of provenances, languages, professions, and motivations to travel to Jerusalem over the centuries.

It also became a refuge for displaced families, as during the two world wars. With the deterioration of the situation in Palestine at the end of 1947 and the outbreak of the civil war between Jewish Zionists and Palestinian Arabs, refugees began to pack the rooms of the casanova. Already in December, part of the structure had been transformed to make space for the refugees. The administrative lists of the Jerusalem casa nova preserve a trace of those heady and dramatic weeks; included among the pages are notations of payments made for "porters to clear out the basement for Refugees" (2,59o Palestinian pounds $)^{22}$ and bills for payments, as well as requests for help on the part of the "Committee of the Christian quarter (harat al-Nasara) in the Old City". ${ }^{23}$

21 Vincent Lemire, ed., Jérusalem: Histoire d'une ville-monde (Paris: Flammarion, 2017).

22 Archivio storico della Custodia di Terra Santa (Historical Archive of the Custody of the Holy Land, ASCTs), Casa nova, Gerusalemme, subfile 1, Contabilità: entrate e uscite della casa nova (January 1923-December 1956), Amministrazione, December 1947. This document shows that operating the building for that month required the Custody to spend 21,326 Palestinian pounds. Items of expenditure in the first half of 1948 also included a payment of 3 oo pounds to the Arab Committee.

23 This is a manuscript page in Arabic, signed by Peter Rock and dated May 8, 1948, in which reference is made to a list of people hosted by the casa nova who expect their allocations of kerosene, cereals, and other goods to be distributed by Mr Jamil Atallah, whose family was also housed in the casa nova. Written on the margin in the same hand is: "Р.то" (probably "pagato" in Italian, paid). Ascts, Casa nova, Jerusalem, Carteggio, "Rifugiati di guerra presso la casa nova di Gerusalemme (January 1, 1947-October 20, 1952)," subfile 5 . 
The friars' desire to make order out of the growing chaos is shown by the publication of a regulation, dated December $29,1947 .{ }^{24}$ This document, a typescript text in Italian and French, is particularly interesting for an understanding of life within the casa nova in the first months of the conflict. It makes clear that the refugees had been accepted through the mediation and intervention of priests, as had already been the case for many pilgrims in previous centuries. It is highly likely, then, that most of them were Catholics from the villages and quarters of Jerusalem that had been occupied by the Zionist troops. The accommodation was not free; every refugee pledged to contribute a small monthly sum for each room occupied. The French text adds that every refugee promised to leave the casa nova as soon as the fighting was over. In order to avoid conflicts, it specifies that this offer was "identical to that made to the Polish refugees" that had lived in the Franciscan hostel some years previously. 25

This source also provides information on the characteristics of the rooms in which the refugees lived; they had one chair per person, one bed, running water - provided for two hours a day from April to November — and a light. The refugees could have the use of a radio for 15 piastres monthly, but it could not be played in the evenings. The casa nova did not provide food, and the refugees could not use the electricity to cook or to iron. The regulations also stipulated that every tenant should provide for the repairs and the cleaning of their rooms, while the casa nova administration would take care of the corridors and baths, which was probably done by nuns. The refugees could only receive visitors for three hours a day and were to return to their rooms by seven in the evening. Finally, every resident was to sign a declaration that they accepted these conditions. ${ }^{26}$ At the moment, documents showing how these rules were enforced

24 ASCTS, Gerusalemme, S. Salvatore, Carteggio, Miscellanea, "Annunci, locandine e volantini legati ad attività e iniziative parrocchiali," subfile 9, Regolamento per i rifugiati in Casa Nova-Gerusalemme durante i torbidi 1947-1948 (Regulation for the refugees in the Casa Nova-Jerusalem during the troubles 1947-1948) (Jerusalem, December 29, 1947). The document bears a manuscript signature - it is not clear whether it is an autograph- "Il Padre Custode". The same regulation was also adopted for the refugees staying at the Flagellation.

25 As has been noted, during World War II, Palestine was one of the principal destinations for tens of thousands of Polish refugees. A part of these refugees were housed in Franciscan buildings, particularly in the casa nova of Ain Karem.

26 The ASCTs preserves some typescript declarations on the casa nova letterhead dated " 1 Gen. 1947" but to be assigned to January 1, 1948, which read: "Il Sottoscritto, accetta in pieno il Regolamento del 29 dicembre 1947 della Casa Nova per i rifugiati durante i torbidi 1947-48 e s'impegna a versare la somma mensile di LP. 3 ("1 one" cancellato) per la (le) stanze che occupa, e lasciare la (le) quando appena cesseranno i turbidi" (ASCTs, Casa 
are missing, but papers from the following years show that the friars were dissatisfied with the level of respect for these rules on the part of their refugee guests.

The documentation also contains the "statement of the account owed by the Arab refugees from the troubles of 1947" and the "statement of collections made in December 1948" on account of the casa nova. The list of debts to be paid was posted inside the casa nova itself, as is indicated in one of the notices that was printed in both English and French. ${ }^{27}$ At the end of December 1948, the refugees housed in the casa nova owed the friars 620,515 Palestinian pounds, while the amount paid for that month was 54,65o Palestinian pounds. In March 1949, the total debt had risen to 810,515 Palestinian pounds. A fixed monthly quota of 1,0oo Palestinian pounds was assigned to one "Joseph le Russe" (Joseph the Russian"), perhaps a middleman who operated some of the services, while the rest was consigned to the leadership.

\section{Between Micro and Global History: Itineraries of the Casa Nova Refugees}

Who lived in the rooms of the casa nova? The "list of refugees at the casa nova" dated September $27,1949^{28}$ mentions 250 persons comprising 70 families hosted in Franciscan premises. This document supplies important data; it notes the number of persons within each room and their "place of residence before the troubles". Many refugees came from quarters of Jerusalem occupied by the Haganah, particularly Katamon, ${ }^{29}$ Musrara, ${ }^{30}$ Rom-

nova, Gerusalemme, Carteggio, "Rifugiati di guerra presso la casa nova di Gerusalemme (January 1, 1947-October 20, 1952)," subfile 5).

27 "The reading of the clause of Casa-Nova's Regulations about the offers fixed, is warmly recommended because there is a real slackness on the part of the refugees. In case of infringement, an overdue detailed list will be posted" (ASCTS, Casa nova, Gerusalemme, Carteggio, "Rifugiati di guerra presso la casa nova di Gerusalemme (January 1, 1947October 20, 1952)," subfile 5, Notice, undated, but probably from the first half of 1949 .

28 Ascts, Casa nova, Gerusalemme, Carteggio, "Rifugiati di guerra presso la casa nova di Gerusalemme (January 1, 1947-October 20, 1952)," subfile 5, Liste des réfugiés à Casa Nova.

29 The families of Victor Tannous (7 persons), Elie Marroum (7 persons), Jabra Araich (6 persons), Jabra Murad (7 persons), Elias G. Yasmineh (7 persons), Artine Poshoglian (4 persons), Andréa Srna (2 persons), Moubarak Saad (6 persons), and Mrs Atallah, "sister of Habesh".

3o The families of Hossep Kechichian ( 5 persons), Georges Taal (4 persons), Antoine Frangieh (6 persons), Elias Morcos (4 persons), Farid Morcos (2 persons), Bechara Morcos (4 per- 
ema, ${ }^{31}$ Bakaa, ${ }^{32}$ the German Colony, ${ }^{33}$ Beit Hakerem, ${ }^{34}$ and Talbieh. ${ }^{35}$ In some cases, the street is specified (Jaffa Road, ${ }^{36}$ Bezalel Street ${ }^{37}$ ), or a reference-point building ("Commercial Centre"38). Unfortunately, no information is provided on professional status or religious denomination.

Most refugees were in families, but there were also some singles. The document records the first and last names of the refugees being housed-for families, the name of the father is indicated - the room number, the total paid or owed, and miscellaneous comments. Some of the most frequently recurring last names are Morcos, Sabella, Atallah, Koury, Seraphim, Safieh, Ayoub, Saad, Nesnas, Karam, Habash, and Calia. Some of the listed refugee residents were also of European or Us origin, having arrived in Jerusalem before the conflict, ${ }^{39}$ as well as a few Polish refugees. ${ }^{40}$

Furthermore, the marginalia note late payments as well as the monthly itineraries of some of the guests; it appears that there were refugees who only spent a few days per month at the casa nova. Others would then use the room to store furniture. Another source, the "list of rooms whose occupants are absent from Jerusalem", ${ }^{41}$ indicates the places to which 29 families housed in the casa nova had transferred: 10 of them to Jericho, 5 to Amman, and the rest to Ayzariyyah, Bethlehem, Salt, and Beirut.

sons), Antoine Safieh (7 persons), Nazar Karjian (5 persons), Hanna Dibsi (7 persons), Bermans Tabri (6 persons), Rosalie Farwagi (2 persons), Hanna Safieh (4 persons), another sister of Atallah, two sisters Salah, Karime Morcos, and Matilda Nassar.

31 The families of Michel Aboushanab (7 persons), Elias Salah (5 persons), and Antoine Dessimeni (6 persons).

32 The families of Antoine Morcos (5 persons), Georges Abdelmessih (3 persons), Nagib Frangieh (4 persons), Rodolphe Habesh (6 persons), Joseph Sabella (2 persons), a certain Mrs Khoury, and Antoine Carmi.

33 The families of Jean Kort (2 persons) and Hanna Izhak.

34 The families of Joseph Nesnas (4 persons), Daoud Carmi (4 persons), and Jamil Nesnas (2 persons).

35 The families of Joseph Habesh (2 persons), Joseph Calis (6 persons), Towfick Ayoub (5 persons), and Marroum Tarsha.

36 The families of Ventura Hallac (2 persons) and Mlle Bahjajian.

37 The family of Jamil Atallah (7 persons).

38 The families of Antoine N. Sabella (6 persons), Ibrahim Nahas (5 persons), Elie Karam (5 persons), Georges Yoakim (4 persons), Margueritte Abcarius (2 persons).

39 And the case, for example, of the names of Bart Frank, Madame Harrington, Edouard Michel, and Tomanova.

40 Merjinsky and Horein.

41 Ascts, Casa nova, Gerusalemme, Carteggio, "Rifugiati di guerra presso la casa nova di Gerusalemme (January 1, 1947-October 20, 1952)," subfile 5, Liste des chambres dont les locataires sont absents de Jérusalem, undated. 


\section{$4 \quad$ Leaving the St Saviour Compound}

With the approach of the war's end, the friars tried to re-take possession of their building, ever more insistently encouraging the refugees to find other accommodation. Numerous notices were distributed and posted in the rooms announcing that it would not be possible to take up permanent residence in the casa nova, nor to hand over the key to someone else, nor to depart for long periods without communicating with the directorate or the nuns who took care of running the building.

At the same time, checks were carried out as to the concrete possibility of paying a contribution based on the real condition of the family and on the occupation of one or more of its members, with remarks deploring cases where refugees were unwilling to contribute economically despite drawing a fixed salary. ${ }^{42}$

In September 1949, the directorate of the casa nova announced that it would no longer be possible to change rooms, but especially that it was necessary for every refugee to prepare to vacate the building as soon as possible, as the friars intended to restore it to its exclusive function: that of a lodging for pilgrims. ${ }^{43}$ The declaration of 1950 as a holy year by Pius XII and the will of the Custody to host the pilgrims who were about to flock to the Holy Land on the occasion of the Holy Year and thus reinaugurate the religious travel interrupted by the fighting of 1947-1949 made it every more urgent for the Franciscans to clear their space, which meant that they increased pressure on the refugees.

Given this growing conflict with the friars responsible for the casa nova, the residents created an internal organization to coordinate their relations with the Custody and to try to delay their departure. In 1950, a committee was organized to calm relations with the friars, to ensure that the residents within the building contributed regular rent payments, and to improve sanitary conditions, "order and discipline" within the residence. ${ }^{44}$ Jamil Bey Nisnas was nominated president of the committee and Negib Frangie was secretary.

42 For example Bermans Tabri "Professeur à Terra Sancta. Touche son salaire comme d'ordinaire. Il n'a rien payé depuis son entrée. Son compte s' élève à LP: 52.000 ” (ASCTS, Casa nova, Gerusalemme, Carteggio, "Rifugiati di guerra presso la casa nova di Gerusalemme (January 1, 1947 -October 20, 1952)," subfile 5, Possibilité d' exiger les offrandes des chambres occupées, unsigned manuscript document). ASCTS, Casa nova, Gerusalemme, Carteggio, "Rifugiati di guerra presso la casa nova di Gerusalemme (January 1, 1947-October 20, 1952)," Avis, September 24, 1949.

44 Ascts, Casa nova, Gerusalemme, Carteggio, "Rifugiati di guerra presso la casa nova di Gerusalemme (January 1, 1947-October 20, 1952)," Frangie to Bellorini, Jerusalem, July 15, 195 o. 
Despite the requests to vacate, in February $195^{2}$ there were still 210 people from 58 families living in the casa nova, occupying 94 rooms. In March 1952, some members of the committee appealed to the heads of the Roman Catholic Church in the Holy Land and to the superior of the casa nova against the decision to evict the 50 families still hosted in the casa nova to make room for the arriving pilgrims. The appeal exhorted them to demonstrate the charitable nature of the Custody and not let economic considerations take precedence over humane ones..$^{45}$ It bemoaned the supposed favouritism toward the Polish refugees ${ }^{46}$ and highlighted the impossibility of the refugees to find accommodation given the high rents in the market. ${ }^{47}$ Finally, confronted with the possibility that the "inhumane work" of trying to hound the families from the casa nova would be realized, it insinuated that the Custody was now using donations from the PMP for purposes other than aid for the refugees. ${ }^{48}$

45 "Nous en sommes bien sûrs que cette institution [the Franciscan Custody] est une institution charitable au mot et non commerciale. Et les pèlerins qu' on voudra installer au Casa Nova saurons que cette place été [sic] réservé à eux après avoir chassé des réfugiés, refuserons de l'occuper." (We are quite certain that this institution [the Franciscan Custody] is truly a charitable and not a commercial institution. And the pilgrims that they wish to install in the Casa Nova knowing that this place has been reserved for them after having chased out the refugees, will refuse to occupy it.) (ASCTs, Casa nova, Gerusalemme, Carteggio, "Rifugiati di guerra presso la casa nova di Gerusalemme (January 1, 1947-October 20, 1952)," subfile 5, Committee of the Casa Nova-Jabra Araich and two non-legible signatures - to the Patriarch, the Apostolic Delegate, the Custos, the "Synod" of the Franciscan priests and the Superior of the casa nova, Jerusalem, March 13, 1952). This letter is also preserved in the archive of the Latin Patriarchate of Jerusalem (ALPJ), Jerusalem (1848-1974).

46 "Les réfugiés Polonais ont habité le Casa Nova pendant huit ans lors de leur arrivée en Palestine et n' ont été pas traité de même, et ne l'ont pas quitté qu' après qu'il était décidé qu'ils quitteraient la Palestine pour leur pays. Et ceux-ci ne lui ont rendu aucun service aux Pères Franciscains comme le peuple de la Palestine l'a fait envers eux." (The Polish refugees have inhabited the Casa Nova for eight years since their arrival in Palestine and have not been treated the same, and have only left after it was decided that they would leave Palestine for their country. And these people have not rendered any service to the Franciscan fathers the way the people of Palestine have done for them.) (Ibid.).

47 'Les réfugiés occupant le Casa Nova n' ont pas le nécessaire pour louer une chambre au déhors, car tout le monde connait que des habitations n' existent pas dehors et s'il en existe les propriétaires en demandent des prix exhorbitants entre 150 à 200 dinars." (The refugees occupying the Casa Nova do not have the necessary means to rent a room outside, since everyone knows that there are no rooms outside, and if there are any, their landlords demand the exorbitant price of between 150 and 200 dinars.) (Ibid.).

48 'Nous n' oublierons pas des centaines des milliers des dollars que la Mission Pontificale a envoyés et ne cesse d' envoyer, les habits et les vivres pour cette pauvre communauté. Et 
After some negiations, an accord was reached in April. Those wishing to continue to occupy their rooms had to comply with new rents, that varied from 250 and $75^{\circ}$ Jordanian dinars per month depending on the size of the room. ${ }^{49} \mathrm{~A}$ certain number of those who had intended to leave the casa nova would instead be able to request a free room if they were without the means to pay.

Meanwhile, the future of the refugees hosted in the casa nova at Nazareth would also be at the centre of a negotiation, this time political, between the Custody and the Patriarchate on one hand and the Israeli government on the other. Internally displaced people originally from the parish of Mujeidel were still living in the Franciscan hostel for pilgrims at the beginning of the 195os, and Patriarch Alberto Gori appealed to the Israeli authorities for authorization for them to return to their homes. ${ }^{50}$

The case of the Franciscan case nove of Jerusalem is clearly just one of the innumerable threads in the story of Catholic aid for the Palestinian refugees, a microhistory that is interwoven with the bigger historical picture. It represents events and processes that, to a large degree, await investigation, and whose analysis would deepen understanding of Palestinian history in important ways.

nous remarquons avec regret que tout cela n'a jamais été distribué avec justice et sagesse. Nous demandons des autorités responsables, la formation d'un comité de six membres, 3 membres du Respectable institution et 3 des réfugiés, dont les 3 membres seront choisis par nous, pour étudier le moyen de distribution de ces sommes, et aussi de savoir en détail l'emploi des ces fonds dans le passé." (We do not forget the hundreds of thousands of dollars that the Pontifical Mission has sent and continues to send, the clothing and food for this poor community. And we note with regret that none of this has ever been distributed with justice and prudence. We demand that the authorities responsible form a committee of six members, three members from the respectable institution and three refugees, with those three members to be chosen by us, to inquire as to how to distribute these sums and also to find out in detail how they have been used in the past.) (Ibid.).

49 ASCTs, Casa nova, Gerusalemme, Carteggio, "Rifugiati di guerra presso la casa nova di Gerusalemme (January 1, 1947-October 20, 1952)," subfile 5, typescript document with no addressee, signed by "The Committee" and dated April 17, 1952. In the committee's view, this was not cheap rent, given that one month earlier in the letter already cited, they had deplored the shortage of rooms and the "prix exhorbitant entre 150 à 200 Dinars" that "font tressaillir les habitants du Casa Nova qui ont besoin du secours urgent dans ces jours des épreuves." (exorbitant price of between 150 and 200 dinars [that] makes the inhabitants of the Casa Nova shudder, who are in urgent need of relief in these testing days.)

$5^{\circ}$ ALPJ, AG-G B 2.1, Gouvernem. Israël-Minist. Cultes 1950-1967, letter n. 788, Gori to Colbi, Jerusalem (November 20, 1953), also available at the Israel State Archives, file 5 ג28. 


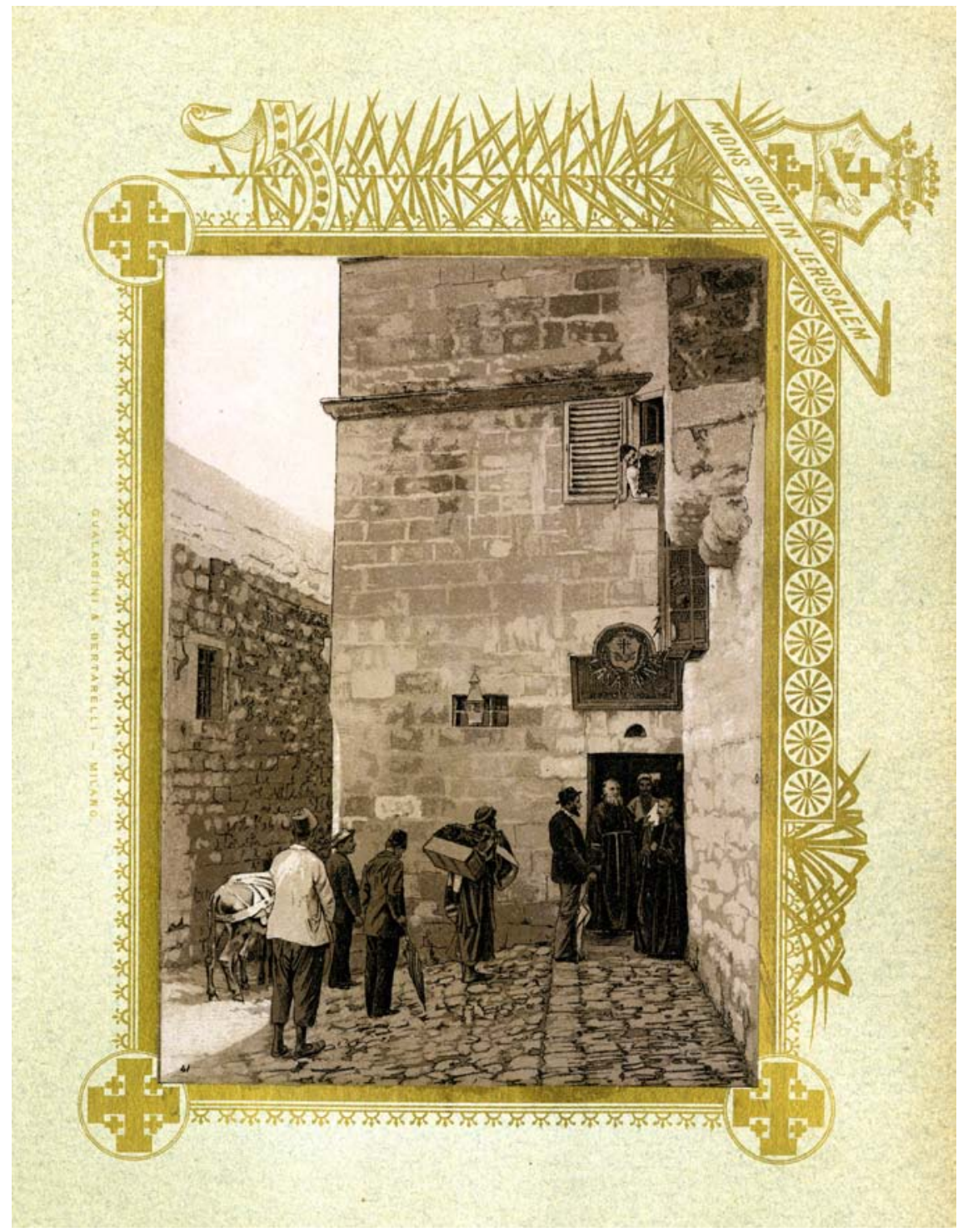

FIGURE $11.1 \quad$ Jerusalem casa nova, early 2oth century, ASCTS

The historical appraisal of the displacements and expulsions of the Palestinian Christian population after 1948, as well as the actions and relations and the local functioning of the system of assistance and the international aid network being mobilized is still an open field of research.

The complex dynamics between "assisted" and "assisting", the forms of control and discipline exercised by operatives of religious entities on those they 
were assisting, and the relations of the kind generated by enforced co-existence, are some of the other themes still to be explored. Finally, the transformation of the religious spaces and the modality of appropriation on the part of families and single refugees, the multiplicity of operations and motivationshumanitarian, religious, economic, political-that make up the complex substrate that enlivened Catholic culture in the provision of aid, and then too, the forms of organization of the refugees themselves with respect to the Catholic hierarchy and, more generally, the mode of politicization that the refugees experimented with, not only in the context of the camps, but also in relation to other structures that accommodated them, such as convents, parishes, and hostels, represent further avenues of research. Through these new sources, to be researched on a transnational scale, the question of the Palestinian refugees itself continues to be at the same time both national and global.

TABLE 11.1 List of the refugees at Jerusalem Casa Nova (1949)

\begin{tabular}{|c|c|c|c|}
\hline $\begin{array}{l}\text { No de la } \\
\text { chambre }\end{array}$ & Nom \& prénom & $\begin{array}{l}\text { Nombre de } \\
\text { personnes }\end{array}$ & $\begin{array}{l}\text { Lieu d' habitation } \\
\text { avant les troubles }\end{array}$ \\
\hline $7 \mathrm{~s}$. & Michel Aboushanab & 7 & Romema \\
\hline 3s. & Victor Tannous & 7 & Katamon \\
\hline $4 / 5 s$ & Elie Marroum & 7 & Katamon \\
\hline $6 s . / 46$ & Antoine N. Sabella & 6 & Commercial Centre \\
\hline $2 s . / 11 / 12$ & Yousseif Abdelmessih & 6 & Jorit-el-ennab \\
\hline $8 s$. & Ibrahim Nahas & 5 & Commercial Centre \\
\hline 9s. & Elie Karam & 5 & Commercial Centre \\
\hline Moteur & Hossep Kéchichian & 5 & Musrara \\
\hline 6 & Ventura Hallac & 2 & Jaffa Road \\
\hline $7 / 8$ & Georges Kaal & 4 & Musrara \\
\hline 9 & Manuel Chomikian & 2 & Transféré de l'Ecole \\
\hline $10 / 45 / 5^{2}$ & Jabra Araich & 6 & Katamon \\
\hline 14 & Matilda Nassar & 1 & Musrara \\
\hline 17 & Bart Frank & 1 & Ancien occupant \\
\hline $22 / 22$ bis & Antoine Frangieh & 6 & Musrara \\
\hline $25 / 26$ & Jamil Atallah & 7 & Bezalel Street \\
\hline 24 & Atallah Sœur & 1 & Musrara \\
\hline 29 & Georges Yoakim & 4 & Commercial Centre \\
\hline $33 / 39 / 51$ & Jabra Murad & 7 & Katamon \\
\hline 35 & Madame Harrington & 1 & Ancienne résidente \\
\hline $36 / 53 / 65$ & Elias G. Yasmineh & 7 & Katamon \\
\hline
\end{tabular}


TABLE 11.1 List of the refugees at Jerusalem Casa Nova (1949) (cont.)

\begin{tabular}{|c|c|c|c|}
\hline $\begin{array}{l}\text { No de la } \\
\text { chambre }\end{array}$ & Nom \& prénom & $\begin{array}{l}\text { Nombre de } \\
\text { personnes }\end{array}$ & $\begin{array}{l}\text { Lieu d' habitation } \\
\text { avant les troubles }\end{array}$ \\
\hline 37 & Jacob Sabella & 2 & Saad-es-said \\
\hline 38 & Merjinsky & 1 & Réfugié polonais \\
\hline 40 & Salah Sœurs & 2 & Musrara \\
\hline $41 / 43$ & Elias Morcos & 4 & Musrara \\
\hline $42 / 64$ & Jean Messih & 6 & Transféré de l'Ecole \\
\hline $5^{\circ}$ & Horein & 1 & Réfugié polonais \\
\hline 55 & Marroum Tarsha & 1 & Talbieh \\
\hline 56 & Farid Morcos & 2 & Musrara (absent) \\
\hline $57 / 58$ & Antoine Morcos & 5 & Upper Baka’a \\
\hline 62 & Bishara Morcos & 4 & Musrara \\
\hline 66 & Artine Poshoglian & 4 & Katamon \\
\hline $67 / 97$ & Antoine Marta & 6 & Transféré de l'Ecole \\
\hline $69 / 70$ & Andréa Srna & 2 & Katamon \\
\hline 71 & Umberto Bussadori & 4 & Jorit-el-ennab \\
\hline 72 & Edouard Michel & 1 & Commercial Centre \\
\hline $73 / 78$ & Jean Kort & 2 & German Colony \\
\hline 74 & Joseph Codrich & 2 & King David Hotel \\
\hline 76 & Elias Salah & 5 & Romema \\
\hline Salon & Antoine Dessimeni & 6 & Romema (absent) \\
\hline 77 & Georges Abdelmessih & 3 & Upper Baka’a \\
\hline 80 & Mlle Bahjajian & 1 & Jaffa Road \\
\hline $81 / 82$ & Mme Démerdjian & 2 & Transférée de l'Ecole \\
\hline 83 & Mlle Julia Damian & 1 & Transférée de l'Ecole \\
\hline $84 / 86$ & Antoine Safieh & 7 & Musrara \\
\hline $88 / 89$ & Nagib Frangieh & 4 & Upper Baka’a \\
\hline $85 / 96 / 93$ & Joseph Nesnas & 4 & Beit Hakerem \\
\hline $87 / 90$ & Rodolphe Habesh & 6 & Upper Baka’a \\
\hline $92 / 91 / 28$ & Daoud Carmi & 4 & Beit Hakerem \\
\hline 94 & Antoine Carmi & 1 & Baka’a \\
\hline 95 & Joseph Habesh & 2 & Talbieh \\
\hline 98 & Michel Abdelnour & 2 & Transféré de l'Ecole \\
\hline 99 & Karimeh Morcos & 1 & Musrara \\
\hline 99bis & Joseph Sabella & 2 & Baka’a \\
\hline Salon & Joseph Calis & 6 & Talbieh \\
\hline $101 / 102$ & Nazar Karjian & 5 & Musrara \\
\hline
\end{tabular}


TABLE 11.1 List of the refugees at Jerusalem Casa Nova (1949) (cont.)

\begin{tabular}{llll}
\hline $\begin{array}{l}\text { No de la } \\
\text { chambre }\end{array}$ & Nom \& prénom & $\begin{array}{l}\text { Nombre de } \\
\text { personnes }\end{array}$ & $\begin{array}{l}\text { Lieu d' habitation } \\
\text { avant les troubles }\end{array}$ \\
\hline 103 & Antoine A. Sabella & 3 & Saad-es-said \\
105 & Tomanova & 1 & $\begin{array}{l}\text { Ancienne résidente } \\
105 / 121\end{array}$ \\
106 & Hanna Dibsi & 7 & Musrara \\
107 & Margueritte Abcarmus & 2 & Katamon \\
& Habesh) & 1 & Musrara \\
108 & Bermans Tabri & 5 & Musrara \\
109 & Rosalie Farwagi & 2 & Musrara \\
110 & Hanna Safieh & 4 & \\
\hline
\end{tabular}

\section{Bibliography}

\section{Primary Sources}

AAY, ACNEWA. McMahon to Spellman, s.l. (December 10, 1948).

Archivio storico della Custodia di Terra Santa [Historical Archive of the Custody of the Holy Land, AScTs]. Casa nova, Jerusalem, subfile 1, Contabilità: entrate e uscite della casa nova (January 1923-December 1956).

ASCTs, Casa nova, Jerusalem, Carteggio, "Rifugiati di guerra presso la casa nova di Gerusalemme (January 1, 1947-October 20, 1952)," subfile 5 .

AScts, Gerusalemme, S. Salvatore, Carteggio, Miscellanea, "Annunci, locandine e volantini legati ad attività e iniziative parrocchiali," subfile 9, Regolamento per i rifugiati in Casa Nova-Gerusalemme durante i torbidi 1947-1948 [Regulation for the refugees in the Casa Nova-Jerusalem during the troubles 1947-1948] (Jerusalem, December 29, 1947).

\section{Secondary Sources}

Achilli, Luigi. Palestinian Refugees and Identity: Nationalism, Politics and the Everyday. New York: I.B. Tauris, 2015.

Akram, Susan, and Terry Rempel. Out of Place, Out of Time: Refugees, Rights and the ReMaking of Palestine/Israel. London: Pluto Press, 2015.

Albanese, Francesca P., and Lex Takkenberg. Palestinian Refugees in International Law. 2nd rev. ed. Oxford: Oxford University Press, 2020.

Al-Husseini, Jalal. "Le statut des réfugiés palestiniens au Proche-Orient: Facteur de 
maintien ou de dissolution de l'identité nationale palestinienne." In Les Palestiniens entre Etat et diaspora: Le temps des incertitudes, edited by Jalal Al Husseini and Aude Signoles, 67-94. Paris: IISM M, 2013.

Al-Husseini, Jalal. "The Arab States and the Refugee Issue: A Retrospective View." In Israel and the Palestinian Refugees, edited by Eyal Benvenisti, Chaim Gans, and Sara Hanafi, 436-464. Berlin: Springer, 2007.

Al-Husseini, Jalal. "The Evolution of the Palestinian Refugee Camps in Jordan: Between Logics of Exclusion and Integration." In Cities, Urban Practices and Nation-Building in Jordan, edited by Myriam Ababsa and Rami Daher, 181-204. Beirut: Presses de l'Ifpo, 2011.

Al-Husseini, Jalal, and Riccardo Bocco. "Dynamics of Humanitarian Aid, Local and Regional Politics: The Palestine Refugees as a Case-Study." In Palestinian Refugees: Identity, Space and Place in the Levant, edited by Arne Knudsen and Sari Hanafi, 128146. Abingdon: Routledge, 2011.

Ashkenasi, Abraham. "The International Institutionalization of a Refugee Problem:The Palestinians and UnRWA." Jerusalem Journal of International Relations 12, no. 1 (1990): 45-75.

Beker, Avi. UNRWA, Terror and the Refugee Conundrum: Perpetuating the Misery. Jerusalem: Institute of the World Jewish Congress, 2003.

Berg, Kjersti G. "From Chaos to Order and Back: The Construction of UnRwA Shelters and Camps, 1950-1970." In UNRWA and Palestinian Refugees: From Relief and Works to Human Development, edited by Sari Hanafi, Leila Hilal, and Lex Takkenberg, 109128. London: Routledge, 2014.

Berg, Kjersti G. "Gendering Refugees: The United Nations Relief and Works Agency (UNRWA) and the Politics of Relief." In Interpreting Welfare and Relief in the Middle East, Social, Economic and Political Studies of the Middle East and Asia, edited by Nefissa Naguib and Inger Marie Okkenhaug, 149-174. Leiden: Brill, 2007.

Berg, Kjersti G. “The Unending Temporary: United Nations Relief and Works Agency (UnRWA) and the Politics of Humanitarian Assistance to Palestinian Refugee Camps 1949-2012." PhD diss., University of Bergen, 2015.

Bocco, Riccardo. "UnRwA and the Palestinian Refugees: A History within History." Refugee Survey Quarterly 28, nos. 2-3 (2009): 229-252.

Bocco, Riccardo and Lex Takkenberg, eds. "UnkwA and the Palestinian Refugees 6o years later." Special issue, Survey Quarterly 28, nos. 2-3 (2009).

Buffon, Giuseppe. Les Franciscains en Terre Sainte (1869-1889): Religion et politique, une recherche institutionnelle. Paris: Cerf; Éditions Franciscaines, 2005.

Deblon, André, Paul Gerin, and Ludovic Pluymers. Les archives diocésaines de Liège: Inventaires des fonds modernes. Louvain: Nauwelaerts, 1978.

Dumper, Michael, ed. Palestinian Refugee Repatriation: Global Perspectives. Abingdon: Routledge, 2006. 
Flapan, Simha. The Birth of Israel: Myths and Realities. New York: Pantheon, 1987.

Gallagher, Nancy. Quakers in the Israeli-Palestinian Conflict: The Dilemmas of NGO Humanitarian Activism. Cairo: American University in Cairo Press, 2007.

Gatrell, Peter. The Making of the Modern Refugee. Oxford: Oxford University Press, 2013.

Giovannelli, Andrea. La Santa Sede e la Palestina: La Custodia di Terra Santa tra la fine dell'impero ottomano e la guerra dei sei giorni. Rome: Studium, 2000.

Hilton, Matthew, Emily Baughan, Eleanor Davey, Bronwen Everill, Kevin O'Sullivan and Tehila Sasson. "History and Humanitarianism: A Conversation." Past \& Present 241, no. 1 (November 2018): e1-e38. (online only).

Klimas, Narcyz S. "Casa Nova di Gerusalemme: L'ospizio dei Pellegrini." Frate Francesco 81 (2015): 197-218.

Klimas, Narcyz S. "Itinerari, guide, racconti, tradizioni o abitudini dei pellegrini in Terra Santa." Antonianum 87 (2012): 93-144.

Klimas, Narcyz S. "Pellegrini a San Salvatore di Gerusalemme: l'ospitalità francescana." Frate Francesco 8o (2014): 96-125.

Knudsen, Are, and Sari Hanafi, eds. Palestinian Refugees: Identity, Space and Place in the Levant. Abingdon: Routledge, 2011.

Kushner, Arlene. UNRWA Supplemental Report: A Rigorous Review of Agency Practices. Centre for Near East Policy Research, 2004. Available at www.israelvisit.co.il/Behind TheNews/pdf/SecondReport.pdf.

Lemire, Vincent, ed. Jérusalem: Histoire d'une ville-monde. Paris: Flammarion, 2017.

Maiarelli, Andrea, ed. L'Archivio storico della Custodia di Terra Santa (1230-1970). Milan: Terra Santa, 2012.

Masalha, Nur. "A critique on Benny Morris." In The Israel/Palestine Question, edited by Ilan Pappe. London: Routledge, 2003.

Menozzi, Daniele. Chiesa e diritti umani: Legge naturale e modernità politica dalla Rivoluzione francese ai nostri giorni. Bologna: Il Mulino, 2012.

Médebielle, Pierre. "Mgr Antoine Vergani (1905-196o): In Memoriam." Jérusalem: Le Moniteur diocésain du Patriarcat latin 26, nos. 3-4 (1960): 54-61.

Morris, Benny. The Birth of the Palestinian Refugee Problem Revisited. 2nd ed. Cambridge: Cambridge University Press, 2003.

Pappe, Ilan. The Making of the Arab-Israeli Conflict, 1947-1951. London: I.B. Tauris, 1992. Pappe, Ilan. The Ethnic Cleansing of Palestine. Oxford: Oneworld, 2006.

Peteet, Julie. "The Afsc Refugee Archives for Palestine 1948-1950." In Reinterpreting the Historical Record:The Uses of Palestinian Refugee Archives for Social Science Research and Policy Analysis, edited by Salim Tamari and Elia T. Zureik, 109-128. Jerusalem: Institute of Jerusalem Studies, 2001.

Pieraccini, Paolo. Cattolici di Terra Santa (1333-2000). Florence: Pagnini, 2003.

Rogan, Eugene L., and Avi Shlaim, eds. The War for Palestine: Rewriting the History of 1948. 2nd ed. Cambridge: Cambridge University Press, 2007. 
Shlaim, Avi. Collusion across the Jordan: King Abdullah, the Zionist Movement, and the Partition of Palestine. New York: Columbia University Press, 1988.

Shlaim, Avi. The Iron Wall: Israel and the Arab World. London: Allen Lane, 2000.

Tamari, Salim, and Elia Zureik. The UNRWA Archives on Palestinian Refugees: A Feasibility Study for Policy and Applied Research; Phase 1. Jerusalem: Institute for Palestine Studies, 1996.

Tamari, Salim, and Elia T. Zureik, eds. Reinterpreting the Historical Record: The Uses of Palestinian Refugee Archives for Social Science Research and Policy Analysis. Jerusalem: Institute of Jerusalem Studies, 2001. 


\section{Index}

Page references marked in bold type indicate a more in-depth treatment of the subject.

abandoned children (Algeria) 138, 139 see also orphans

ABCFM see American Board of Commissioners for Foreign Missions

Abdülhamid II Massacres see Armenian Massacres

Abdülhamid II (Ottoman sultan, 1894-1896) 211

abolitionists $\quad 46,47,48,51,57,58,183 \mathrm{n} 1$

Aboriginals 134

Abyssinia/Abyssinians 44

slaves 47,48

ACASR see American Committee for

Armenian and Syrian Relief

ACG see American College for Girls

Acre (Israel) $\quad 262$

ACRNE see American Committee for Relief in the Near East

Actes de notoriété (Algeria) 144

Adana (Cilicia) 187, 190, 201

adoption 139

Africa/Africans $\quad 158,235,246,248$

slaves $8,42,43,47,48$

see also freed slave girls

AFSC (American Friends Service Committee) 257

Agouche, Sitt (slave master) $\quad 48$

agricultural economy see rural development

Albanians 65

Aleppo

American missions in 188,190

Armenian refugees in $188,190,196-197$, 203

French welfare spending in $\quad 202$

missionary schools in 188,215

Alexandria, art and crafts school 24

Algeria

anti-clericalism in $\quad 27,33,137,140,146,148$

Christian Arabs in $141,142,150$

model villages $10,134,144-150$

citizenship/naturalization $\quad$ 140-142, 146, 150

civil vs. religious law $\quad 141,149$

famine (1866-1869) 10, 134, 135, 138-142
French missions/missionaries in 133,151

funding of missionary activities in 27 ,

144,145

Jews in $140,141,146$

Kabyles in 136, 141, 142

orphans/orphanages 10, 138-139, 141, 142, 143-145, 149

political tensions and missionary work

133-134, 135, 136, 137, 139-140

republicans vs. radicals $140,141,146-147$, 148

(transformation of) Catholic Church in

133, 135-137, 142

Algiers 135, 139, 141, 143n36, 144

Ali, Mehmet 55

Allenby, General Edmund 221

Alliance Française 135

Alloula, Malek 65ng

Alsatians 144

alumni/alumni associations $\quad$ 78ill., 169, 193

American Board of Commissioners for For-

eign Missions (ABCFM) 4n13, 8, 68, 111

Asiatic Turkey Mission (Anatolia) 8-9,

$62-63,67,68$

changing/widening of approach by 63

conversion to "Christian" civilization

\section{$73^{-85}$}

body and home politics $\quad 73-80$

health $80-82$

funding/fundraising $\quad 64,164$

history and achievements $\quad 62-63,96 n 23$, 97

hospitals $\quad 55^{-56,96,97,99}$

medical missions $\quad$ 8o-82, 16o, 163

organization of missionary work $\quad 67-68$

orphanages $\quad 67-73,97$

public relations/Missionary Herald $\quad \mathbf{6 3}^{-}$ $65,66,67$

schools/colleges $\quad 101,156,16 \circ, 167$

transnational missionary cooperation

95

visual/photographic representation of missionary work $\quad 8-9,62,65-67,70-$ 72ill., $75^{-} 77,75^{-78 i l l ., ~} 83,84$ 
see also American (Presbyterian) mis-

sions/missionaries; Near East Colleges

American Board of Missions (Presbyterian Church) $\quad 189$

American Catholic missions/missionaries in Beirut 33-34, 35

in Palestine $\quad 259,261$

American Civil War (1861-1865) $5^{1}$

American College for Girls (ACG, Istanbul) 156, 16o, 166, 177, 178

see also Near East Colleges Association

American Colony (Jerusalem) 241

American Committee on Armenian Atrocities 187

American Committee for Armenian and Syrian Relief (ACASR) 157, 162, 170, 188, 199 see also Near East Relief

American Committee for Relief in the Near East (ACRNE) 188, 192-193ill. see also Near East Relief

American Friends Service Committee (AFSC, Philadelphia), archives $\quad 257$

American (Presbyterian) missions/missionaries and humanitarian work $8,11,24$, $42,44,55-56,96,126,189$

in Anatolia $\quad 8-9,62-63,67,68,96,97$, 99

for Armenians (Syria) 186-19o, 191, 198, 200, 201, 203

for Assyrians 111n1, 125, 191

auxiliary mission work $\quad 158,160-161$

in Balkans $62 \mathrm{n} 2$

(boarding) schools $41,43,44-45,5^{\circ}$, 52-54, 58, 194 see also Near East Colleges

bureaucratization of $\quad 160-161,184,190$, 194-195

competition with French relief providers 200

for freed slave girls (Egypt) 41, 44, 45, 50, $51,52,54,55,56,57$

fundraising 191-192, 192-193ill.

fusion of missionary work/evangelization and humanitarian work 9, 91, 110

for Greeks $\quad$ 189, 191

in Levant 10, 98, 203

Orientalism and racial/ethno-religious thinking $42,82-85,184,190-197$, 192-193ill. in Philippines $\quad$ 195, 198, 199

political dimensions/politicization 197199, 200-2o3, 204

in Republic of Turkey $\quad 171,190$

secularization of missionary work 156 , $158,159,160-161,163-164$

see also American Board of Commissioners for Foreign Missions; "Machine Age humanitarianism"; Near East Colleges Association; Near East Relief; Rockefeller Foundation

American Protestant missionary colleges see Near East Colleges

American Red Cross $\quad 2,161,187,189$, 19o, 200

American Relief Administration 189

American University of Beirut (AUB) funding and donor dependency 10, 165, $166,168,170,171,172,178$

secularization of $163,164,194$ see also Syrian Protestant College

American University of Cairo (AUC) $\quad 164$

Amman 258, 266

Amos, Sarah $\quad 48-49$

Anatolia

American missions/missionaries in $\quad 8-9$, $62-63,67,68,96,97,99$

Armenians in $\quad 8-9,62-63,90,93,94$

German missions/missionaries in

84n73, 101-102

missionary hospitals $\quad 96,97,99$

orphanages $\quad 67-73,96,97,102$, 105ill.

Scandinavian missions/missionaries in

84n73, 9o-91, 92, 94, 105ill.

schools in 99,101-102

Turks in 93, 99

Anderson, Betty 186

Anglican Church 239

cooperation/ecumenical relation with

Church of the East 112, 114, 115, 116, 117-118, 125-126

Anglican Church Missionary Society (CMS) 159, 168, 216

Anglican missions/missionaries 110

for Assyrians $\quad$ 111-114, 125

in Hakkari Mountains 110, 111-113, 120

in Iraq/Mesopotamia $\quad 9,113-114$

in Persia 111-113

hospitals $\quad 25,56$ 
racial/ethno-religious thinking in/by

$$
\text { 122-123, } 125
$$

refugee camps 110, 113

relation with Church of the East 112,115

schools/educational projects $50,113,114$,

212n15, 213n24, 239, 242

support to patriarchal family $112,113,114$ see also British missions/missionaries;

Wigram, Rev. William Ainger

Anglo-Egyptian Slave Trade Convention

(1877) 47

Anthropology (Edward Burnett Tylor) $123 n 48$

anti-clericalism (Algeria) 27, 33, 137, 140, 146,148

anti-semitism $\quad 140,226-227,226 \mathrm{n} 75$

Anti-Slavery Society (London) $183 \mathrm{n} 1$

APF (Association for the Propagation of the

Faith) 31,32

Apprentis d'Auteuil (French Catholic foundation) 138

Arab armies attack (Palestine, 15 May 1948) 253

Arab civilization, renewal of $\quad$ 141-142

Arabic language

Arabic language education at missionary schools 50, 194

Arabic skills of missionaries $\quad 42,49$

as language of instruction 194, 212

Arab-Israeli War (Six-Day War, 1967) 250

Arab League 253

Arab refugees 11, 248, 249 see also Palestinian refugees

Arab Revolt (Palestine, 1936-1939) 198, 224, 226, 240

Arab riots (Palestine, 1929) 223

Arabs

Finnish missions/missionaries and 11, 233, 235, 239, 243-244, 246, 249, 250251

in Palestine/Israel 233, 235n6, 239, 240, 246

racial thinking about $\quad 122,134$

right to inhabit Palestine/Israel 243-

244, 247, 249-250

see also Christian Arabs

Arab University of Damascus 166

Aram (Armenian orphan) 70, 7oill., 71

Archbishop of Canterbury 112, 117
Archbishop of Canterbury's Mission to the Assyrian Christians 110, 11

archdiocese of Paris, archives 259

archival material, on Palestinian refugee

issue $\quad$ 255-262, 268n45

Armenia

American humanitarian activities in 188, 189, 19o, 191, 200, 201

lack of direct American mandate over 198, 199

see also Cilicia

Armenian Apostolic Church 94

Armenian language $\quad$ 97, 102

Armenian Massacres (Hamidian massacres, 1894-1896) 8, 68, 72, 94-95, 187

Armenian missionaries $\quad$ 96-97, 99, 100, 102

Armenian nationalists, establishment of schools 103

Armenian orphans $\quad 6,67-73,70-72 i l l ., 91$, 95, 105 ill.

education of $99,101-102$

Armenian refugees $\quad 6,168,187-188,196-197$, 203

Armenians/Armenian community $\quad 1,65$, 110, $122 n 41$

American missions/humanitarian work for 186-19o, 191, 198, 203

in Anatolia $\quad 8-9,62-63,90,93,94,99$ conversion/spiritual reformation of 8 $9,62,63,72,79,97-98,191$

German missions for $\quad 97-98$

persecution/genocide of $5,6 \mathrm{n} 23,8,12$, $68,94-95,220$

photographic representation/description of $62,65-67,68,69-72,70-72 i l l .$, $75^{-77,75-76 i l l ., ~} 92$

reception of missionary work $63,97-98$, 103

Scandinavian missions/humanitarian work for $5,6,9,90,92-93,95,97-103$

art and craft schools (Alexandria) 24

Asia 235

"Asiatic Turkey" see Anatolia

Assa (slave girl) $5^{2}$

Association for the Propagation of the Faith (APF) 31,32

Assyrian Church of the East see Church of the East

Assyrian refugees 110,117 
Assyrians/Assyrian community $\quad 1,110$

American missions for 111n1, 125, 191

Anglican missions for $\quad$ 111-114, 125

conversion of 112

customs 115

ancient ecclesiastical rites/ceremonies

$$
118,121,123-124,126
$$

French missions for 112

German missions for 111

identification with ancient Assyrians/old civilizations 119, 121-123, 126

militarization by British in WWI 9, 110, 116,125

resettlement/integration in Iraq 114, 117, $123,124,126$

Russian missions for $\quad 111,113$

in Syria $\quad 113,126$

see also Church of the East; Wigram, Rev.

William Ainger

The Assyrian Settlement (William Ainger

Wigram) 116

The Assyrians and their Neighbours (William

Ainger Wigram) 116, 122

Asyut (Egypt) 45, 51, 52, 54, 55

Atallah, Jamil $\quad 263 n 23$

Atour.com (Assyrian website) $\quad 116$

AUB see American University Beirut

AUC (American University of Cairo) 164

Audet-Gosselin, Louis 22

Austria-Hungary, public funding of mission-

ary activities 170

autonomy $1,27,155,170,172$

auxiliary mission work $158,160-161$

'Ayzariyya (West Bank) $\quad 266$

Badger, George Percy 111

Baer, Gabriel 42

Bahçe (Turkey) 200-201

Baka’a (neighbourhood, Jerusalem) 266, $272 t a b$.

Balfour Declaration (1917) 244

Balkans, American missionaries in $\quad 62 \mathrm{n} 2$

baptism, of freed slave girls 53,54

Baquba (Iraq), British refugee camp 110, 113, 114

Bardizag (Anatolia), Bithynia High School 77, 78ill.

Baring, Sir Evelyn (Earl of Cromer) $\quad 41,48$, $49,5^{\circ}, 5^{2}, 54$
Barlassina, Luigi (Latin Patriarch of Jerusalem, 1920-1947） $25^{8}$

Barnes, Ellen 24

Barnett, Michael 183, 184, 209, 210, 225

Baron, Beth $\quad 2,8$

Barton, James L. 187, 199

Bebaydi (North Iraq) 113, 114

Becker, Adam 125

Bedouins 45

Beilin, Yossi $\quad 245 \mathrm{n} 43$

Beirut 175, 190, 266

French missions/missionaries in 23, 25 migrants/refugees in 26,162

orphanage 23

schools/colleges 215 see also American University of Beirut; Syrian Protestant College

Beit Hakerem (neighbourhood, Jerusalem) 266

Ben-Néfissa, Sarah 22

Beth-Jala (Palestine) 237

Bethlehem 240, 259, 266

BFASS (British and Foreign Anti-Slavery Society) 48,49

biblical geography, of Palestine 120

Bikfaya (Mount Lebanon), orphanage in 23

Biørn, Bodil 9, 103-104, 107ill.

background and career $\quad$ 9o, 93-94

establishment of girls school 102, 104, 1o7ill.

establishment of polyclinic 99, 100

qualifications and certification $\quad 98,100$

reception of missionary work 100-101, 102, 104

working environment 96

Bithynia High School (Bardizag) 77, 78ill.

Bjørnlund, Matthias 94

Bliss, Daniel 82

Bliss family $\quad 186$

boarding schools

for freed slave girls (Cairo) 41, 43, 44-45, 50, 52-54, $5^{8}$

in Israel 241, 245, 250-251

body and home politics (ABCFM) $\quad 73-80$

Bøgh, Eli and Karen (independent missionaries) 239, 247n49

Bolsheviks 250

Bourmaud, Philippe 10

Bozarslan, Hamit 21 
Bremond, Edouard $\quad 200-201$

British Empire see Great Britain/British Empire

British and Foreign Anti-Slavery Society (BFAss) $\quad 48,49$

British mandates see Iraq; Palestine

British missions/missionaries

funding of 168

hospitals $\quad 25,56$

in Iraq 9, 113-114

in Palestine/Israel 4n11, 6, 234, 236, 240, 243

schools 5 o, 113, 114, 212n15, 213n24, 239,

242

see also Anglican missions/missionaries

British Red Crescent Society $\quad 223$

Brown, Adela (missionary teacher) 44, 53

Browne, William Henry $\quad$ 112-113

Bugeaud, Thomas Robert 142

bureaucratization, of missionary and humanitarian organizations $160-161,184,190$, 194-195

Burkina Faso 22

Cairo

American (Presbyterian) missions/missionaries in $8,5^{1}$

(boarding) schools in $41,43,44-45,50$, 52-54, 58, 215

French missions/missionaries in $\quad 25$ see also freed slave girls

Capuchin missions/missionaries $\quad 25,32$

Carthage (Tunisia) 134

casa nova (Jerusalem) 12, 253, 256, 27oill.

expansion of $\quad 262-263$

as hostel for pilgrims $\quad 262-263,262 \mathrm{n} 20$,

$267,268 \mathrm{n} 45$

as infirmary 262

operating costs $263 \mathrm{n} 22$

as refuge $\quad 263-265,267$

facilities, rents, and regulations $\quad 264-$ $265,265 \mathrm{n} 27,269$

list of refugees $\quad 265^{-266,265^{-}}$ 266n29-40, 271-273tab.

origin, status and itineraries of refugees $\quad 265^{-266}$

for Palestinian refugees $\quad 260-261$, 263-269 repossession by friars/departure of refugees $\quad 267-269$

statement of accounts $\quad 265$

casa nova (Nazareth) 261, 269

casa nove (Palestine) 261, 262

Catholic Church

in Jerusalem/Israel 12

see also Franciscan Custody of the

Holy Land

in North Africa/Algeria $\quad 22,133, \mathbf{1 3 5}^{-137}$,

142

Catholic missions/missionaries 4, 5, 7, 21, 111

competition with Protestant missionaries/missions 159,165

funding/fundraising $27,29,31,135,170$

in Levant $\quad 8,34$

medical action and $\quad 12-13$

see also casa nova (Jerusalem); Daughters of Charity; Dominican missions/missionaries; French missions/missionaries; Jesuit missions/missionaries

Catholic Near East Welfare Association (CNEWA, United States) 259 archives 259, 261

Catholic Personalism $\quad 258 \mathrm{n} 11$

Catholic refugees, in casa nova (Jerusalem) 264

Cattin, Fr. Lucien 33

Central Turkey Mission (ABCFM) 62

Century Theatre (New York) $\quad 187$

Chaldeans/Chaldean community 112

Chambers, William Nesbitt $\quad$ 200-201

charity/charitable action $\quad \mathbf{2 3 - 2 6}$

humanitarianism vs. traditional $\quad 183^{-}$ 184

see also humanitarian actions/work; missionary activities/work

Charles M. Hall Estate 164

Chehadé, Chehadé 200, 200n71

children $\quad 189$

charitable activities for poor 23,24

education of $\quad 28-29$

see also orphans

children's homes

in Jerusalem 11, 237, 241

see also orphanages

China 155,158

colleges $167,171,176,177$ 
Finnish missions/missionaries in 235 medical missions in $171,176,216$

Rockefeller projects in $157,163,171,176$, 177

China International Famine Relief Commission 163

Christian Arabs

in Algeria $141,142,15^{\circ}$

mixed marriage $\quad 145,147,149$

model villages $10,134,144-150$

in Syria $\quad 142,142 n 33$

Christian Arab villages see model villages

The Christian (British periodical) $\quad 5^{2}$

Christian Brothers of Bethlehem 29

"Christian" civilization, conversion to 9,62 , $63,65,66,67,73-8$ o, 82-85, 134, 209, $212-213,218,236,239,246$

Christian Hebrew Centre (Jerusalem) $\quad 238$

Christianity, as Asiatic faith 118

Christian minorities $10,94,103,204$ see also Armenians/Armenian community; Assyrians/Assyrian community; Christian Arabs; Greeks; Maronite Christians

\section{Christians}

civilization of Muslims vs. 120

expulsion of 110

funding of humanitarian actions 8 , 22

Christians of the Middle East 259

Church of the East $\quad 9,110,111,115^{-116}$ cooperation and ecumenical relations with Anglican Church $112,114,115$, 116, 117-118, 125-126

"fossilized" Church concept (Wigram) 121, 123-124, 126

naming of $115,121-122$

works on $\quad 115^{-116}$

see also Assyrians/Assyrian Community

Churchill, Winston 189

Church of Scotland 211, 22O-221, 221, 222, 225, 226, 227

fundraising 224

union with United Free Church of Scotland 222, 223, 225

(Women's) Jewish Mission Committees 211, 221, 222, 223, 224, 226, 227

see also Scottish Presbyterian missions/missionaries
Church of the Teutonic Knights 32

Cilicia (Lesser Armenia) 188, 199

American humanitarian activities in 188, 190, 200, 201

orphanages 201

schools 201

see also Armenia

Cilician crisis (1922) $\quad 188$

citizenship (Algeria) 140-142, 146, 150

civilization

Assyrian 119, 121-123, 126

conversion to "Christian" $9,62,63,65$,

$66,67,73-8$ o, 82-85, 134, 209, 212-213, 218, 238, 239, 246

evolution of civilizations $\quad$ 119-121

renewal of Arab 141-142

civil law, Shari'a vs. $\quad 141,149$

Civil War in Palestine (1947-1948) see

Palestine War

cleanliness $73-74,75,213$

see also "Christian" civilization

Clot-Bey, A.B. (French medical expert) 55

clothing style $71,73,76$ ill., 84

of women $77-8$ o, 79ill., 1o6ill.

see also "Christian" civilization

CMs (Anglican Church Missionary Society) 159, 168, 216

CNEWA (Catholic Near East Welfare Association) 250,261

Coakley, J.F. $\quad 111,125$

colleges (missionary)

in China $167,171,176,177$

Jesuit 28, 32

see also Near East Colleges

Cologne 32

colonial humanitarianism 134

colonial/imperial missionary involvement $3,123,125,126,155$

see also political interests/tensions

colonial independence, development of mis-

sionary work after 21, 22

colonial mandates, emergence of 184

colonial projects, of Maronite Christians 142, 142n33

colonial settlements/projects see Jewish settlements; model villages

Comati, Nicolas 29

Combes, Michel 148

Committee of the Holy Sepulchre $\quad 32$ 
competition, between missionary organizations/relief providers 103, 159, 165, 200, 221-223, 225, 226, 227

Congo 137

Congregation of the Oriental Church 259

Constantine 135

Constantinople see Istanbul/Constantinople Constantinople Woman's College see American College for Girls

Continuation War (Finland/Soviet Union, 1941-1944） 248-249

conversion

in Algeria $\quad 141$

of Armenians $\quad 8-9,62,63,72,97-98,191$

of Assyrians 112

of Copts $\quad 8,5^{1}$

education as indicator of 101, 102, 212213

of freed slaves/slave girls $8,46,51,5^{2-}$

53,57

of Greeks 63

indicators of

"Christian" civilization/change in living conditions/customs $9,62,63$, $65,66,67,73-8$ o, 82-85, 134, 2o9, 212-213, 236, 239, 246

health conditions $\quad 64-65,80-82,101$, 216, 221

of Jews $\quad 63,210,212,213,218-219,221$, 226-227, 235, 237, 237-238, 241, 247 of Kabyles 136

of Muslims $\quad 51,63,118,135,191,193-194$,

210-211, 219, 221

naturalization as act of 141

of orphans $\quad 68,69,73-74,139,141,145$

of Orthodox Christians $83,210,219$

of tribes 145

of women 79,92

cooperation see missionary cooperation

Copenhagen 95

Copts, conversion of $8,5^{1}$

cotton production/trade 43

The Cradle of Mankind: Life in Eastern Kurdistan (William Ainger Wigram) 115-116,

117-121

mixing of biblical and classical illusions

in $120-122$

republication of $\quad 116$ reviews of $118 \mathrm{n} 22,119 n 24$

stereotyping in 120

title page 120,121

Crane, Charles 170

Craver, Rev. Samuel 199

Crémieux Decree (1870) 140, 141

Crewe, E. (matron of Home for Freed Women Slaves) $\quad 49$

Crimean War (1853-1856) 31

crowdfunding 171-173

cultural conversion see "Christian" civilization

curricula, at missionary schools 53,102 , 102n $45,213-214,246$

customs

as indicator of conversion $9,65,67$, 74

see also "Christian" civilization

Cyprus 114, 26o

Dalman, Gustav 217

Damascus 8, 169

missionary schools $\quad 24-25,194$

Darfur 51, $5^{2}$

Daughters of Charity

food distribution $\quad 25$, 33ill.

funding of missionary activities 27,28 , 29

orphanage (Beirut) 23

school (Damascus) 24-25

silk mill (Tripoli) 25, 28

Davidson, Randall (Archbishop of Canterbury, 1903-1928) 113

deaconess training $90,93,99$

death, fear of $\quad 81-82$

The Death of a Nation, or the Ever Persecuted Nestorians or Assyrian Christians (Abraham Yohannan) 113

De Caix, Robert 203

De Damas, Father Amédée $\quad$ 32-33

Delitzschianum (Leipzig) $\quad 238$

Denmark 91, 239n21 see also KMA

Deutsche Orient Mission 95

Deutscher Hülfsbund für Christliche Liebeswerk im Orient $\quad$ 92, 93nı, 95, 97, 98

hospitals 99

schools 99, 101-102 
diasporas $2,243,245 \mathrm{n} 43,248$

fundraising in 169

long-distance nationalism in $\quad 169$

diocese of Liège, archives $\quad 259$

divorced women 138

Djelloul, Philippe (local drunkard) 148

The Doctrinal Position of the Assyrian Church

(William Ainger Wigram) 115

Dodge, Bayard 170

Dodge, Cleveland 170

Dodge, William E. 30

Domestic Frontiers: Gender, Reform, and American Interventions in the Ottoman

Balkans and the Near East, 1831-1908 3

domesticity/domestic labour $67,74,80,213$, 213n24, 220

see also "Christian" civilization

domestic servants 23

freed slave girls $\quad 49,54,55,57$

orphans 143, 144

domestic slaves 43

Dominican missionaries/missions $\quad 112,126$

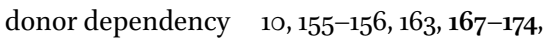

177

see also Near East Colleges Association;

Rockefeller Foundation

donors see funding of missionary and

humanitarian work

Druze 23

see also Syrian Civil War

Dunant, Henry $183 n 1$

Dupuch, Antoine-Adolphe (Bishop of Algiers, 1838-1845) 144

Eastern (Catholic) Churches $\quad 32,115$

see also Church of the East

Eastern Orthodox Church 115,117

Eastern Turkey Mission (ABCFM) 62

East Karelians $\quad 250$

Ebel, Jonathan 219

ecclesiastical archives, on Palestinian refugee issue 256-262

ecclesiastical rites and ceremonies, survival

of ancient $\quad 123^{-124}$

ecumenical movements/initiatives 219, 220, 225

ecumenical relations, between Anglican

Church and Church of the East 112, 115, $116,117,125^{-126}$ education

of girls and women 101,220

freed slave girls $8,25,5^{\circ}, 5^{2}$

as indicator of conversion/civilizational process 101, 102, 212-213

of orphans 99, 101-102, 143

reception of educational projects 214215

Scottish Presbyterian missionaries/missions 211-215, 223, 224, 225

shift from evangelization to $1,6,23,210$ see also schools (missionary)

Egypt 8, 47, 155, 210, 220, 253

American missionaries in $41,44,51,5^{2}$, $54,56,57$

orphanages 24

slavery/slaves in $41-42,43,46,47$, $5^{8}$

Sudan and 43, 46

see also freed slave girls

Ekbladh, David $\quad 157$

Ekblad, Signe $\quad$ 240, 241, 249

Elazig (Mezreh, Turkey) 96

elderly people $\quad 26,138$

Elim orphanage (Mezreh, Anatolia) 96

Elshakry, Marwa 63

Emaus/Emmaus orphanage (Mezreh, Anato-

lia) $96-97,102$

emergency relief $\quad 5,9,91,210, \mathbf{2 2 1}-\mathbf{2 2 4}, 227$

Emmaus (Palestine) 262

employment, freed slaves/slave girls 47,48 , $49,54-56,57$

England 114, 116

English Lord Mayor's Fund 190

English missions/missionaries (Palestine) 238

Episcopal missions/missionaries 114

Essenberg, Christine Adamson 194

Ethiopia/Ethiopians 44, 45, 56

see also Abyssinia/Abyssinians

ethnic/religious groups, anthropological/sociological articles on $\quad 65$

ethno-religious thinking

by missionaries/in missions $\quad \mathbf{1 2 1 - 1 2 3 , 1 2 5}$

see also racial thinking

Europe

funding of missionary and humanitarian

activities $8,22,27,30,31,34$

migration to 126 
European civilization, Kurdistan/Assyrians as origin of 119,121

Evangelical Lutheran Church of Finland 235n4-5

evangelization at hospitals 25 shift to/fusion with humanitarian work 1, 6, 9, 21, 23, 91, 97-98, 104, 110, 16o, 210 Ezbekiah Boarding School (Cairo) 41, 43, $44-45,5$ ○, 52-54, $5^{8}$

Faggala (district of Cairo) $\quad 5^{2}$ famine in Algeria (1866-1869) $\quad 10,134,135,138-$ 142

in Norway (Napoleonic wars) 90 in Syria $\quad 161$

Fanna (slave girl) $\quad 5^{2}$

fear of death $81-82$

FELM (Finnish Evangelical Lutheran Mission) $235,236,238,241,249$

female missionaries $\quad 9,96,97$ reception and status of $95 \mathrm{n} 2 \mathrm{O}, 100-101$, 102, 104 see also Biørn, Bodil; Johansson, Alma; KMA

female slaves see freed slave girls; slave girls Filles de la Charité du Bon Pasteur d'Angers 25 see also Daughters of Charity

financing see funding of missionary and humanitarian work

Finland 91, 238 independence of $\quad 246,248-249$ Jews in 235,235 n4

Russia/Soviet Union and 235, 235n4, 238, 238n13, 246, 248, 249 population transfers $25^{\circ}$

Sweden and 248

Finnish Civil War (1918) 246, 248

Finnish Evangelical Lutheran Mission (FELM) 235, 236, 238, 241, 249

Finnish missionaries/missions (Jerusalem) association with Jews/pro-Jewishness

233, 235, 236, 238, 241, 243-244, 245,

$246,247-248,250$

children's home $11,237,241$

conversion attempts $239,247,248$

history and evolution $\quad$ 234-241 missionary cooperation $\quad 238$

political viewpoints/neutrality $\quad 233^{-234}$, 245,248

reception by local community and government $234,234 \mathrm{n} 3,238$

schools 237, 238

(shift to) humanitarian work 11, 237, 245, 249, 250

views on/missionary work for Arabs/Arab refugees 11, 233, 235, 239, 243-244, 246, 248, 249, 250-251

see also Havas, Aili; Moisio, Rauha

Finnish Mission Society (FMS) 235 see also Finnish Evangelical Lutheran Mission

Fiorovich, Father (Jesuit priest) $\quad$ 25, 29

Flambeau Shop (New York City) 197

Fleischmann, Ellen $\quad$ 186, 219-220

Flew, Sarah 168

FMS (Finnish Mission Society) 235

food distribution/relief $\quad 25,32,33$ ill., 190

Forsythe, David 183nı

Forte National (commune, Algeria) 149

"For Young People" (section of Missionary

Herald, АвСFM) $\quad 63-64,67$

"fossilized" Church (concept, Wigram) 121, 123-124, 126

Fowler, Esther and John (Quaker couple) 24

Fowler Orphanage (Presbyterian orphanage, Egypt) 24

Frachebois (local politician, Algeria) $\quad 148$

France/French Empire

anticlerical programme of 33

charity by religious congregations in 23

French colonial rule vs. American foreign rule 195

orphans/orphanages $\quad 138,143,149$

public funding of missionary activities/state subsidies $\quad 27, \mathbf{3}^{\circ}-\mathbf{3 1}, 33, \mathbf{1 4 4}$, 145

diplomatic control/political influence over aid receivers $\quad 169-170$

see also Algeria; French Mandate Government for Syria and the Lebanon

Franciscan Custody of the Holy Land (Jerusalem Church) $\quad 256,262,267,268$ archives 260, 261, 268 see also casa nova (Jerusalem) 


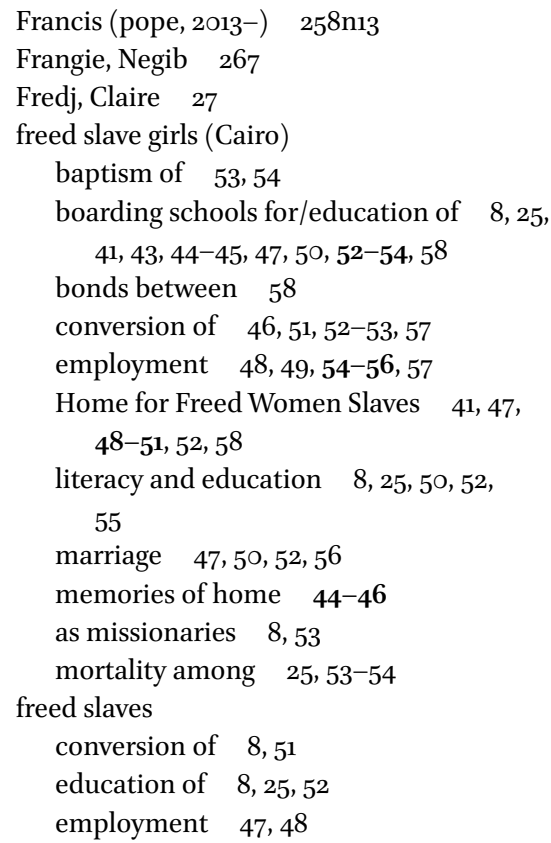

Freienwalde (Germany) 95

French (Catholic) missions/missionaries and humanitarian work 133, 149

in Algeria $\quad 133,151$

during famine $\quad \mathbf{1 3 8 - 1 4 2}$

alliance between militarism and missionary work 137

in Cairo 25

competition with American relief providers 200

funding of $3^{0-31}, 33,144,145,169-170$

in Levant 202

orphanages $138,143,149,202$

political interests/tensions $\quad 133^{-134,135}$,

137, 139-140

racial/ethno-religious thinking 134 ,

149

see also Dominican missions/mission-

aries; Jesuit missions/missionaries;

Lavigerie, Charles Martian Allemand; model villages

French Mandate Government for Syria and

the Lebanon

funding for welfare and humanitarian aid 2O2-2O3

reception of missionary activities/societies 5
American humanitarianism/“AngloSaxon" interference $10-11,165$, 184, 185, 186, 197, 199, 200-203, 204 see also Lebanon; Syria

French Protestant missions/missionaries 133n1

French Third Republic see Algeria

Friedman, Milton $\quad 169$

Friedrich, Norbert 210

Friends' Foreign Mission Association 187

From Mission to Modernity, Evangelicals, Reformers and Education in NineteenthCentury Egypt 3

funding of missionary and humanitarian work $26,34,64$

crowdfunding and philanthropy $\quad \mathbf{1 7 1}^{-}$ 173

democratization of funding $\quad 169$ donor dependency $\quad 10,155^{-156,163,167-}$ 174, 177 international funding $\quad 30-31$ large individual donors $\quad 167-168$ local funding $\quad 8,22,27-3$ o, 34 public funding/state subsidies $\quad \mathbf{1 6 9 - 1 7 1}$

Europe $\quad 8,22,27,30,31,34$

France $27,30-31,33,144,145,169-$ 170

Germany 170

Italy 170

Ottoman State $\quad 29-30$

United States $\quad 22,27,30,31,169,170-$ 171

see also Rockefeller Foundation

fundraising for missionary and humanitarian work $3^{2-35}, 64,135,169,172,191-192$, 192-193ill.

in New York 168, 187, 191, 195, 197, 259

Furneaux Pelham (England) 114

Gagneux, Lieutenant 201

Galilee 219n44, 261

Gardey, Delphine $\quad 160$

Gates, Dr 69-70, 81-82

Gaza Strip 253

General Curia of the Little Brothers at Rome, archives 261

genocide see Holocaust; massacres

German Colony (neighbourhood, Jerusalem) 266, $272 t a b$. 
German Deaconess School (Marash, Anatolia) 99

German missions/missionaries $\quad 1,96,97$ in Anatolia $\quad 84 n 73,93 n 10,97,101-102$ for Armenians $\quad 97-98$

for Assyrians 111

hospitals 99

orphanages $1,96,200-201$

in Persia 111

reception of $\quad 97-98$

women's mission organizations 9 in 4 see also Deutscher Hülfsbund für Christ-

liche Liebeswerk im Orient; Kaiserswerth Deaconesses

Germany

Nazi 11, 226, 245

public funding/state subsidies for missionary activities 170

relation with Ottoman Empire 98

germ theory of illness 80

girls schools/education 101, 102, 103, 104, 107ill., 193-194

see also freed slave girls

global modernization, missionary/humanitarian work and $157,158,179,219-220$

Golan Heights 253

"Golden Rule" Sunday 188

Gori, Alberto (Latin Patriarch of Jerusalem, 1949-1970) 269

"Gospel Triumph in the Land of Ararat" (Rev.

G.C. Reynolds) 75

government schools, missionary schools vs. 102-103, 214-215

Great Britain/British Empire $\quad 47$

attitude towards mission societies 5

British colonial rule, American foreign rule vs. 195

colonial humanitarianism $\quad 134$

militarization of Assyrians in WwI 9, 110, 116, 125

military and humanitarian spending in

Middle East $\quad 189$

women's mission organizations $\quad 9104$

see also Iraq; Palestine

Great Syrian Revolt (1925) 165, 169, 198

Great War see World War I

Greece 114, 220

American missions in $\quad 189$

population transfers with Turkey 250
Greeks 65, 220

American humanitarian activities for 191

conversion of 63

Gregorian Church 97, 98

Haganah (paramilitary organization of Jewish population in Palestine) $\quad 265$

Hakkari Mountains (Turkey/Iraq), Anglican missionaries in 110, 111-113, 120

Halima (slave girl) $\quad 45,46,48,5$ O, 54-57

Hall, William H. 198

Hamidian massacres see Armenian Massacres

Hammer, Christa 96

Hanoteau, Adolphe $\quad$ 136n14

Harput 69, 70

Harvey, Dr 54, 55

Harvey, Henrietta $\quad 54,55$

Harvey, Lulu 55

Al-Hasakah (district, Syria) 202

Hauser, Julia 5, 92

Havas, Aili $\quad$ 11, 233, 236-244, 245, 246, 247$25^{\circ}$

home school 237,238

on influence and success of Jews in

Palestine 241-242, 244, 248

mission home in Jerusalem 11, 236-237,

239

on rights of Jews/Arabs to inhabit

Palestine 243-244, 247, 248, 249-

250

surveillance, censorship, and arrest of 238, 238n14, 241

on (violent) nationalism/nation-state

ideology in Israel $\quad 242-243,249-250$

health/health conditions

contribution to 23

as indicator of conversion $\quad 64-65,80-$

$82,101,216,221$

shift from evangelization to $1,160,210$ see also medical missions/missionaries

health institutions see hospitals/health institutions

Hebrew Christian Alliance $\quad 223,238$

Hebrew language $\quad 245,245 \mathrm{n} 43,248,250$

as language of instruction $212,238,239$, 245,246

Hebrew University (Jerusalem) $\quad 236$ 
Hebron 225

medical missions in $\quad 216$

missionary hospitals $\quad 25,221$

Hellenic Travel: A Guide (William Ainger Wigram) 117

Helsinki, Jewish school/kindergarten 235n4

A History of Humanism, 1755-1989 (Silvia Salvatici) 3ng

Holiness movement 9103

Holocaust 11, 245, 246, 248, 249

Holy Land 4, 120, 243 see also Israel

home economics see domesticity/domestic labour

Home for Freed Women Slaves (Faggala, Cairo) $\quad 41,47,48-51,52,58$

home politics (ABCFM) 73-75

see also "Christian" civilization; living conditions

Homs 193

hospitality see casa nova (Jerusalem); casa nove

hospitals/health institutions $\quad 23,81,9$, 262

American $\quad 55^{-56}, 96,97,99,189$

Anglican/British 25, 56

evangelization at $\quad 25$

German 99

Scottish Presbyterian $\quad 221$

Zionist 222

household hygiene $\quad 73-74,75$

see also "Christian" civilization

humanitarian actions/work 3, 22

funding see funding of missionary and humanitarian work

labour cost $\quad 159-160$

missionary vs. 22

political dimensions of 197-199

(religious) motivations behind $\quad 7,191$

shift to/fusion with missionary work 1 ,

$6,9,21,23,91,97-98,104,110,160,210$ see also relief work

humanitarianism

colonial 134

definition 4, 209-210, 225

global modernization and $157,158,219-$ 220

history and evolution of $4,7,21,184,185$

politicization of 200-203 role of religion/missionary work in devel-

opment of 10, 21-22

traditional charity vs. $\quad 183^{-184}$

see also "Machine Age humanitarianism"

humanitarian organizations 2

bureaucratization of $160-161,184,19$ o, 194-195

Hurnard, Miss Hannah (independent missionary) 239

hygiene $73-74,75,80,81-82,84,213$

body and home politics of ABCFM $73^{-}$ 80

see also "Christian" civilization

Illinois $\quad 5^{1}$

imperial/colonial missionary involvement

$3,123,125,126,155$

see also political interests/tensions

India $155,213,239 n 21,25^{\circ}$

Intercommunion with the Assyrian Church

(William Ainger Wigram) $\quad 116$

International Committee of the Red Cross

(Geneva) 183nı

archives 257

International Hebrew Christian Alliance 218

Interwar period $\quad 6,10,25,161,169,171,176$

Scottish Presbyterian missions/missionaries in 209, 219-225

An Introduction to the History of the Assyrian

Church (William Ainger Wigram) 115, 118, 122

Iran see Persia/Iran

Iraqi Revolt (1920) 198

Iraq/Mesopotamia 110, 121, 220

Anglican/British missionaries in 9, $113^{-}$ 114

British Mandate rule $\quad 117$

resettlement of Assyrians in 114, 117, 123, 124, 126

see also Assyrians/Assyrian community

Islamic charity (waqf) 183-184

Islamic law see Shari'a

Israel

Arab villages in $\quad 253$

boarding schools $\quad 241,245,25^{\circ}-25^{1}$

foreign-funded NGO s in $\quad 155$

immigration $245^{-246}, 247,249$

independence of $23,237,245$ 
nationalism/nation-state ideology $\quad 242-$ 243, 249-250

settlements/annexations $\quad 233,240,242$, 253

see also Finnish missions/missionaries;

Jerusalem; Palestine

Israeli-Arab conflict (1948) see Palestine War Israeli-Palestine War (1947-1948) see

Palestine War

Istanbul/Constantinople $\quad 99,100,170,190$, 200

colleges in $156,16 \circ, 166,177,178$

missionaries in 114,189

refugees in 162

Italy, public funding/state subsidies for missionary activities 170

Jacobsen, Maria $\quad$ 96, 99

Jaffa, missionary schools 211, 211n1o, 215, 223

Jalabert, Fr. Louis 32

Jalagin, Seija 11

Jazeera (region, Syria) 114

Jeddah/Jidda 48

Jensen, Jenny 96

Jericho 266

Jerusalem $\quad 258$

annexation of East Jerusalem $\quad 253$

children's homes 11, 237, 241

Finnish missions/missionaries in 233244

internationalization of $\quad 259$

missionary schools $\quad 215,239,240,241$

orphanages $\quad 1,237$

rights of Jews/Arabs to inhabit $\quad 244,247$, 248

student homes 11

see also casa nova (Jerusalem)

Jerusalem Church see Franciscan Custody of the Holy Land

Jesuit missions/missionaries (Syria)

boys orphanage 23

funding/fundraising $\quad 27, \mathbf{2 8}, \mathbf{2 9}, \mathbf{3 1}, \mathbf{3 2 -} \mathbf{3 3}$

schools/colleges $\quad 28-29,32,166$

Jesuit Université Saint-Joseph (Syria) 28, 166

Jewish Medical Mission (Edinburgh) $\quad 218$

Jewish Mission Committees (Church of Scotland) 211, 221, 222, 224, 226, 227
Jewish nationalism $\quad 169,242-243,245,249-$ 250

see also Zionism/Zionists

Jewish refugees (Jerusalem) 11-12, 236-237, 238,249

Jewish settlements (Palestine) 233, 240, 242

Jewish state see Israel

Jews/Jewish community 118

in Algeria/North Africa $140,141,146$ naturalization of Jews 140, 141

conversion of Jews/Christian Jews 63 , 210, 212, 213, 218-219, 221, 226-227, 235, $237,237-238,241,245,247$

in Finland 235, 235n 4

in Israel/Palestine colonies/settlements $\quad 233,240,242$ Jerusalem 11-12, 233, 236-237, 238, 241, 249 right to inhabit Israel/Palestine 243244, 247, 248, 249-250

persecution of Jews 226-227

see also Finnish missions/missionaries;

Zionism/Zionists

Jinks, Rebecca $\quad 6 \mathrm{n} 23$

Johansson, Alma 92, 96, 99, 100

Jones, Gwladys 212

Jordan (country) 220, 244, 253, 259, 26 o

Jordan (river) 217n4O, 247, 253

Kabyles (Berber people, Algeria) 136, 141, 142

Kabylie (region, Algeria) 136n14

Kahlenberg, Caroline 8on57

Kaiserswerth Deaconesses (Beirut) 5, 92, 99

Kaminsky, Uwe 210

Karelia (Finland) 250

Karmel Association (Finland) 243

Karmel (magazine, Finnish Karmel association) 243

Al-Kashkūl (Sunni Beiruti newspaper) 191, 193

Katamon (Jewish neighbourhood, Jerusalem) 265, 271-273tab.

Kateb, Kamel 140

Keltuma (slave girl) $\quad 5^{2}$

Kemalism/Kemalist regime (Turkey) 165, 175,177 
Keswick Conventions 81

Khabur (river, Syria) $\quad 125$

Kharpert (Anatolia) 93, 99, 101

Khartoum 44, 45, 55

Khoshaba, Qasha (priest) 121, 122

Kim, Shin K. 80

King-Crane Commission (US) 199, 200, 20on 71

King's School (Canterbury) 114

Klingberg, Frank $183 \mathrm{n}$ 1

KMA (Kvinnelige misjonsarbeidere, Women

Mission Workers) 9, 9o-92, 95n2o, 104

cooperation with other mission organizations $\quad 95^{-96}$

foundation/evolvement of $91,94-$ 95

fusion of evangelization and humanitarian work 91, 94-95

local reception of work 92 mission/goal 91

Kozma, Liat $\quad 42-43$

Kragerø (Norway) 93

Kurdistan 110, 119, 120 see also [The] Cradle of Mankind

Kurds $65,93,99,122$

Kuusamo (Finland) 250

Kvinnelige misjonsarbeidere see KMA

Kyle, Ella $\quad 54$

labour costs, of humanitarian missionary work 159-16o

Lambeth Conference (1908) 115

Lang, Cosmo Gordon (Archbishop of Canterbury, 1928-1942) 113

language skills $\quad 42,49,97,240$

language training 102, 212

Lankaster, Herbert $\quad 216$

Lapland War (1944-1945） 249n5o, 250

Latin America 126, 235

Latin Patriarchate of Jerusalem $\quad 256 \mathrm{n} 7,258$, 259 archives 26o, 268n45

Laura Spelman Rockefeller Memorial Fund (LSRM) 162

Lausanne Treaty (1923) 165

Lavigerie, Charles Martial Allemand (Cardinal and Archbishop of Algiers) $\quad 151$ businesslike approach of $\quad$ 135-136, 137
Christian Arab model villages $\quad$ 10, 134, 144-150

life and legacy $\quad$ 134-136

on renewal of Arab civilization 141-142

transformation of Catholic Church in

North Africa $\quad$ 135-137

Lawrence, Miss (independent missionary) 239

Lazarist missions/missionaries $\quad 111,112$

League of Nations $\quad 5,10,123,185,186,197$, 198

Lea (Jewish refugee) 237

Lebanon 220

missionary schools $\quad 187$

see also French Mandate Government for Syria and the Lebanon

Lee, Olin 201

Lesser Armenia see Cilicia

Lester, Alan 134

Letourneux, Aristide $\quad$ 136n14

letters by missionaries $\quad 92-93$

for fundraising $32,33,34$

Levant 8

alumni associations $\quad 169$

American humanitarian activities in 10 , 198, 203

Catholic and Protestant missionary activities in 34

competition between relief providers 200

French (humanitarian) missionaries/missions in 202

see also Egypt; Palestine; Syria

Levison, Leon $\quad 218-219,219 n 44$

Liège, diocese of, archives $\quad 259$

literacy

freed slave girls 55

male vs. female 103

living conditions

as indicator of conversion $9,65,66,67$,

74-75, 209

see also "Christian" civilization

Lloyd George, David 198

local authorities/communities, influence

on/reception of missionary work 5,92 , $98,102,234,238$

local funding, of missionary and humanitarian work $8,22,27-3$ o, 34

Lodi, Fr. Paoli di 262 
Löffler, Roland $\quad 1,210$

Lønnå, Elisabeth 93

Lorcin, Patricia $\quad$ 136, 142

Lorrains 144

Louisant, Berthe (domestic servant) 144

Lovisenberg deaconess institution (Kristiania, Oslo) 9o, 93

LSRM (Laura Spelman Rockefeller Memorial Fund) $\quad 162$

Al-Lubnān (Beiruti newspaper) 189

Lutheran missions/missionaries 97, 235 see also Finnish missions/missionaries;

German missions/missionaries

McAfee, Harold B. $\quad$ 188, 203

Macaulay, Thomas Babington 213

McCoy, Alfred 194

"Machine Age humanitarianism" 10, 184, 186, 204

Orientalism and 190-197

see also American (Presbyterian) missions/missionaries and humanitarian work

McKown, Margaret $\quad 5^{2}$

MacMahon, Patrice de 135

McMahon, Thomas $\quad$ 259, 261

Madagascar 133

Maghreb 22

see also Algeria; Egypt; Palestine; Syria;

Turkey

magic 118

Mahé, Alain $\quad 136,142$

Makdisi, Ussama $\quad 82-83$

Maksudyan, Nazan $\quad 8-9$

Mallouk, N. (donor) 168, 171-172

Malta 114, 137

mandates $5,184,198,220$

Mandates Commission (League of Nations) 197,198

manners 73, 213 see also "Christian" civilization

Marash (Anatolia), German missionary hospital 99

Margarit (girls school teacher) 102

Maritain, Jacques 258n11

Maritza (girls school teacher) 102, 107ill.

Maronite Christians (Lebanon) 23, $119 n 26$

colonial project $\quad 142,142 n 33$

see also Syrian Civil War
Marquand, Frederick $\quad 30$

marriage

freed slave girls $\quad 47,5^{\circ}, 5^{2}, 5^{6}$

mixed marriage $\quad 145,147,149$

orphans 143n36, 144, 145

Mar Shimun xIx Benyamin (patriarch, 19031918), missionary support to family $\quad 112$, 113,114

Mar Shimun XVIII Ruel (patriarch, 18611903) 112

Marten, Michael 11, 239

massacres 23, 117

Armenian Massacres (1894-1896) 8, 68, 72, 94-95, 187

see also Holocaust

Massignon, Louis, archives of 259

Mayers, Norman $\quad$ 202-2O3

Mecca 244, 248

slave trade in 47,49

media

links to missionaries/missionary work 10 promotion of missionary work in $\mathbf{6 3}^{-}$ 65,171

medical education/schools

in Algeria 143

in Ottoman Empire 99

in Syria 163,166

see also American University of Beirut;

Near East Colleges

medical missions/missionaries 23

in Algeria 143

American 8o-82, 16o, 163

Anglican 159

balance between spiritual and medical work 216-218

in China 159, 171, 176, 216

cooperation and funding 163,171

as indirect tool of conversion 221

investments/costs $160,216 \mathrm{n}_{3} 6$

in Palestine 216-219

professionalization of 210

purpose of 216

reception of 5,81

for refugees 10

Scottish Presbyterian $\quad$ 11, 211, 216-219,

222

see also Biørn, Bodil; health/health conditions; hospitals/health institutions

Merguerian, Barbara J. 101 
Methodists $91 n 3$

Mezreh (Anatolia) 93, 96, 97

Miaphysite tradition $\quad 116$

midwifery/midwives 100-101, 104 see also Biørn, Bodil; Johansson, Alma

migration 12,126

to/from Israel/Palestine 240, 244-246, 247, 249, 253-254

militarization, of Assyrians by British in wwI

$$
\text { 9, } 110,116,125
$$

militarism, alliance between missionary work and 137

Mindan, British refugee camp 113

al-Minyawr, Mustapha (slave master) $\quad 48$

missionaries

language skills $42,49,97,240$

recruitment of $161,174-176,177$

as world citizens vs. citizens of nation-

state 219

missionary activities/work

by freed slave girls 8,53

contested methods $\quad$ 158-16o

donor dependency $10,155^{-156,167-174}$

funding see funding of missionary and

humanitarian work

global modernization and 157,179

humanitarian work vs. 22

"NGOization" of 10, 13, 22

reception of $5,81,92,96,97-98,102-103$, 104, 214-215, 234, 238

role in development of humanitarianism 10, 21-22

secularization of $10,21-22,156-157,158$, 159, 16o-161, 163-164, 167, 174-175, 177

shift to/fusion with humanitarian work

$1,6,9,21,23,91,97-98,104,110,16 \circ, 210$

see also political interests/tensions

missionary colleges see colleges (missionary) missionary cooperation

between missionary organizations $\quad 95^{-}$ $96,161,191,202,238$

cooperation/relation with political authorities 137, 165, 178, 209

Rockefeller Foundation and Near East

Colleges Association $\quad \mathbf{1 5 6 - 1 5 8 , ~ 1 6 1 , ~}$

$162,163,164,165,166,171-176,177-178$, 179

Missionary Herald (АВСFM) 66

"For Young People" section $\quad 63-64,67$ missionary hospitals see hospitals/health institutions

missionary organizations, bureaucratization and technocratization of $160-161,184$, 19o, 194-195

missionary schools see schools (missionary)

Mission Stories in Many Lands: A Bookfor Young People (ABCFM) 64

Miss Whately's Mission School 50

model villages

in Algeria $10,134,144-15^{\circ}$

economic dependence of $146,15^{\circ}$

opposition/criticism $\quad 145^{-147,150}$

in Sub-Saharan Africa 150

modern humanitarianism $\quad 184$

modernization

humanitarianism and $157,158,219-220$

of society 102, 219-220

see also "Christian" civilization; global modernization

Mohamed Sacid Pasha (Governor of Egypt, r. 1854-1863) 46-47

Moisio, Rauha $\quad 238,241,245^{-246,248}$

Mokrani Revolt (Algeria, 1871) 140

Monnot, Fr. 34

Monroe, Elbert B. 30

Monroe, Paul 198

Morgenthau, Henry 170

Morning Call (New Jersey newspaper) 197

Morris, Benny 255

mortality, among freed slave girls $\quad 25,53-$ 54

Mosaic law 140

Moscow Armistice (September 1944) $25^{\circ}$

Moses, Margot 237

Mosul 112

Mounier, Emmanual 258n11

Mount Lebanon $\quad 26$

orphanage 23

seminary college $\quad 3^{2}$

Mount Lebanon Civil War (186o) 1, 8, 12, 23, 29

Mount Lebanon Ladies Relief Society

(Boston) $\quad 189$

Mowafi, Reda 43

Mujeidel (Al-Mujaydil, Arab-Palestinian village) $\quad 269$

Munich 32

Murre-van den Berg, Heleen 9, 241 
Musch (region, Anatolia) 103

German missions/missionaries in

93n10, 97, 102

Scandinavian missions/missionaries in

9o, 92, 98, 105ill., 107ill.

Muslim charitable institutions 191

Muslims 118

civilization of 120

conversion of $51,63,118,135,191,193^{-194}$, 210-211, 219, 221

funding of humanitarian actions $\quad 8,22$

muslim children in missionary schools 193-194

Musrara (neighbourhood, Jerusalem) 265, 271-273tab.

\section{Nakba see Palestine War}

Napoleonic wars 90

Napoleon III (Emperor of the French, r. 18521870) 133,138

Naquib, Nefissa $\quad 184$

National Armenian Union (NAU) 188

nationalism 219

Jewish nationalism (Israel) 242-243,

$245,249-250$

long-distance nationalism in diasporas 169

missionary activities inspired by 157 , 161, 169, 177

violent 242

see also Zionism/Zionists

nation-state ideology $3,219,242-243,249-$ 250

naturalization (Algeria)

as act of conversion $\quad 141$

in Algeria $\quad 140-141,146,150$

of orphans $141,142,144$

natural sciences 80

NAU (National Armenian Union) 188

Nazareth 259

casanova $\quad 261,269$

Nazi Germany $\quad$ 11, 226, 245

Near East colleges (American Protestant missionary colleges)

administration of $\quad 160-161$

donor dependency 171,172

funding/fundraising $156,161,167,172,173$ crowdfunding and philanthropy 171173 large individual donors $\quad$ 167-168

state subsidies $\quad 170-171$

political influence of and on $171,177,178$

recruitment of staff $\quad 174-176$

secularization of $167,174-175,177$

self-supportiveness $167,172,173,178$

supervision of 16o-161

transformation into relief organizations 161

transformation into research institutions 166-167, 176

see also American College for Girls; American University of Beirut; Roberg

College; Rockefeller Foundation; Syrian Protestant College

Near East Colleges Association (NECA) cooperation with Rockefeller Foundation 156-158, 161, 162, 163, 164, 165, 166, 171176, 177-178, 179 agenda dependency $173-174,177-178$, 179

in medicine $\quad 163,171$

newsletter 171

see also Near East Relief

Near East Foundation (NEF) 10, 157, 161, 167 see also Near East Relief

Near East Industries (NER project) 197

Near East Relief (NER) 2, 6, 161, 166, 167, 187-188, 189, 204

approach 184

cooperation $2 \mathrm{O} 2$

cost-cutting $\quad 188-189$

donors 189

funding/fundraising $\quad 189,191,195^{-197}$, 196ill., 203

hospitals $\quad 189$

orphanages $\quad 189$

political tensions/politicization 200, 201 religious motivation 191

schools 188

stereotyping of beneficiaries 191-192, 192-193ill.

support from Rockefeller Foundation 10,162

in Syria/Lebanon 188-189

see also American Committee for

Armenian and Syrian Relief; American Committee for Relief in the Near East; Near East Colleges Association 
NECA see Near East Colleges Association NEF see Near East Foundation

NER see Near East Relief

Nestorian Church see Church of the East

New Near East (magazine, NER) 196, 199 newsletters/bulletins $32,34,63-65,171,196$, 199

New York

fundraising in $168,187,191,195,197,259$ missionary organizations in $160-161$

NGO S 21, 34, 155

"NGOization" of Christian missions 10, 13,22

see also donor dependency; political interests/tensions

Nile 45

Nisnas, Jamil Bey $\quad 267$

NMS (Det Norsket Misjonsselskap) 95n2o

Non-Governmental Organizations see NGO s

Nordic missions/missionaries

claim of political neutrality $\quad 233^{-234}$

in Palestine $\quad 236$

see also Scandinavian missions/missionaries

Norseth, Kristin 91

Det Norsket Misjonsselskap (NMS) 95n2O

North Africa

Catholic Church in $\quad 22,133,135^{-137,142}$

French missionaries in $\quad 134$

Jews in 140, 141

North America, women's mission organizations 9104,190

Norway 91

famine 90

health system 90

modernization 93

women's mission organizations $\quad 95 \mathrm{n} 20$

Norwegian missions/missionaries 95 see also Biørn, Bodil; KMA; Scandinavian missionaries/missions

Norwegian Mission Society (Det Norske Misjonsselskap) $95 \mathrm{n} 2 \mathrm{O}$

Nubia 25, 45

Nubians 44

nurses/nursing 9o, 91, 93, 95, 96

freed slave girls as nurses $\quad 55^{-56}$

training of nurses $90,93,99$

see also Biørn, Bodil

Nye, Joseph $\quad 17 \mathrm{n} 78$
Occupied Enemy Territory Administration

(Palestine) 221

Ohio $5^{1}$

Okkenhaug, Inger Marie $\quad$ 9, 84n73, 184, 239

Oliver, Daniel and Emily (Quaker couple) 187

Onésime, Brother 29

Ora (Jewish refugee) 237

Orientalism 184, 192-193ill.

"Machine Age humanitarianism" and 190-197

Oromo (people, Ethiopia) 44

orphanages $\quad 23-24$

in Algeria $\quad$ 138-139, 143

in Anatolia $\quad 67-73,96,97,102,105$ ill.

in Armenia $\quad 68,69$

in Bahçe 200-201

in Cilicia 201

in Egypt 24

in France $138,143,149$

in Jerusalem 1, 237

in Lebanon $\quad 189$

in Levant $\quad 202$

orphans 23

Algerian 10, 138-139, 141, 142, 143-145,

149

Armenian 6, 67-73, 70-72ill., 91, 95, 99, 101-102, 105ill.

conversion of $\quad 68,69,73^{-74}, 139,141,145$

education of 99,143

marriage $143 n 36,144,145$

as missionaries 143

naturalization/citizenship of 141,142 , 144

as paid domestic servants 143,144

upbringing/transformation of $69,71,72$ see also model villages

The Orphan Scandal: Christian Missionaries and the Rise of the Muslim Brotherhood 2-3

Orthodox Christians, conversion of 83,210 , 219

Orthodox Church of Finland $235 \mathrm{n} 5$

Orthodox communities $\quad 63,84$

conversion of 83,210

see also Armenians/Armenian community

Oslo 9o, 92, 95

Oslo peace process (1993) 255 
Ottoman Empire $\quad$ 120, 184, 220

American missions/missionaries in 62$63,62 n 7,16$ o

Anglican missions/missionaries in 111

expulsion and persecution of Christians 5,110

female missionaries in 9

funding of missionary activities $\quad 29-30$

health system 100

reception of missionary work 98, 104,

155,185

medical/health work $81,96,99$

schools/educational projects 102103, 211-212, 214-215

relation with Germany $\quad 98$

slavery in $42,45,47$

state vs. missionary schools $102-103$,

$$
\text { 214-215 }
$$

tanzimat reforms $\quad$ 211-212, 215

Ottoman Turkish language $\quad 102$

Ouahes, Idir 10

Our Lady of the Seven Sorrows (congregation founded by Fr. Fiorovich) 25-26

Our Smallest Ally (post-war pamphlet, William Ainger Wigram) 110, 116

CEuvre des Écoles d' Orient (Society of Eastern Schools) $30,31,32$

Pacific 133

Paderborn (Germany) 32

Pailloux, Fr. 34

Pakistan 250

Palestine 220

American missions/humanitarian work in 19o, 191, 259, 261

biblical geography of 120

British missions/missionaries in 4nu1, 6, 234, 236, 238, 240, 243

Catholic missions/missionaries in 8,12 , 259, 261

Finnish missions/missionaries in $\mathbf{2 3 3}^{-}$ 244

Jewish immigration and settlements/

annexations $233,240,242,253$

missionary hospitals 25

partition of $233,242,253$

reception of missionary work/organiza-

tions $5,11,226$ refugee camps 253

Scandinavian missions/missionaries in 236

Scottish Presbyterian missions/missionaries in 11, 209, 210, 213, 226, 238

in Interwar Period $\mathbf{2 1 9 - 2 2 5}$

medical missions in $\quad \mathbf{2 1 6 - 2 1 9}$

schools 211-215

Swedish missions/missionaries in 6, 238

see also Israel; Palestine War

Palestine Riots (1929) 223

Palestine War (War of Independence/Nakba, 1947-1949) 1, 7, 11, 12, 227, 241, 245, 253, 258, 259, 261, 263

Palestinian Liberation Organization (PLO) 253

Palestinian refugees (Jerusalem) 1, 12, 253

archival material on $\quad \mathbf{2 5 5}^{-\mathbf{2 6 2}}, \mathbf{2 6 8 n} 45$

in casa nova $\quad$ 26o-261, 263-269

migration of 253

opposing narratives in historiographies

254

right to return 253

secular vs. Christian humanitarian aid 257-258, 257-258n11

see also Arab refugees; Jewish refugees

Palestinians, exodus/migration of $\quad 23,253^{-}$ 254

Panfil, Dr 114

Pari Mutuel horse races $\quad 169$

Paris, archdiocese of 259

paternalism 139

Paterson, Dr Alexander 221, 225

patriotism 243, 249

see also nationalism

Paulmann, Johannes 4, 185-186

Pearce, Richard M. 163, 166, 167-168, 172, 173,176

Pedersen, Susan 197

Peel Commission Report $\quad 224$

Peking Union Medical College $\quad 176$

Pennsylvania 51,187

persecution

of Armenians $\quad 5,6 \mathrm{n} 23,8,12,68,94-95$, 220

of Jews 226-227

Persia/Iran 111 
Anglican missions/missionaries 111-113 Russian Orthodox missions/missionaries 111, 113

see also Assyrians/Assyrian community personal hygiene $\quad 73-74,80,81-82,84$ see also "Christian" civilization

Petsamo (Finland) 250

philanthropy 171-173

see also Rockefeller Foundation

Philippines, American humanitarian work in $195,198,199$

photographic representation/description of missionary work $8,9,62,65,92$

before-and-after photographs 62 , 65-67, 68, 69-72, 70-72ill., 75-77, 7576 ill.

of orphans $67,70-72$ ill., 105ill.

role classification and conceptualiza-

tion of "other" peoples 79ill., 83-84, 106ill.

see also "Christian" civilization

pilgrims

hosting of pilgrims $\quad 261,262-263$,

262n2o, 267, 268n45

smuggling of slaves by $47-48,49-50$

Pirotte, Jean 151

Pittsburg-Post Gazette 194

Pius XII (pope, 1939-1958) 258, 258n13, 267

Pius XI (pope, 1922-1939) 259

PLO (Palestinian Liberation Organization) 253

PMP see Pontifical Mission for Palestine

Polish refugees (Palestine) 264, 264n25, 266, 268, 268n46

political interests/tensions 5

agenda dependency $173-174,177-178,179$

humanitarian activities and 197-199

imperial and colonial missionary involvement $3,123,125,126,155$

missionary activities and 5

Algeria $133-134,135,136,137,139-140$

Rockefeller Foundation $\quad$ 164-166, 177, 200

Syria/Lebanon $\quad 185$

state subsidies $\quad \mathbf{1 6 9 - 1 7 1}$

see also donor dependency; reception of

missionary work

political neutrality, of Finnish and Scand-

inavian missions $\quad 233^{-234}$ politicization, of humanitarian work 200203, 204

polyclinics see hospitals/health institutions

Pontifical Mission for Palestine (PMP) 259, 26o, 268, 269n 48

archives 258, 259

poor people

charitable activities for 23,24

distribution of food to $25,32,33$ ill.

Port Suez 45, 47

postcards, for fundraising $\quad 32,65 \mathrm{n} 9$

Powell, Eve Troutt $\quad 41,43$

Presbyterian missionaries/missions see

American (Presbyterian) missions/missionaries and humanitarian work; Scottish Presbyterian missionaries/missions

Pressly Memorial Institute (Asyut) $\quad 5^{2}$

prisoners 23, 25

Proschaska, David 65 ng

proselytism see conversion

prostitutes 23, 48

Protestant missionaries/missions 4, 5, 7, 34, 111

auxiliary mission work $\quad 158,160-161$

competition with Catholic missionaries/missions 159,165

education 101, 159

equality of men and women in mission ideology 92, 103

funding of 27

medical work 159

religious vs. secular goals $158,159,16$ o161

see also American (Presbyterian) missions/missionaries and humanitarian work; Finnish missionaries/missions; Scandinavian missionaries/missions; Scottish Presbyterian missions/missionaries

Prudhomme, Claude 21

public relations $\quad 63-65,171$

see also photographic representation/description

Qodshanis (Hakkari Mountains) 112

Quakers 24, 187, 257

racial thinking $\quad 244$

by American missionaries/missions 
by Anglican missionaries/missions $\quad 122-$ 123,125

by French missionaries 134, 149

see also American Board of Commissioners for Foreign Missions

racism 220

Rafael (Jewish refugee) $\quad 237$

Raffety, Edward 191

Rais al-Tin Palace (Alexandria) $\quad 65 \mathrm{n} 11$

Ramle (Israel) 262

reception of missionary work $5,81,92,96$, 97-98, 102-103, 104, 214-215, 234, 238

recruitment of missionaries $161,174-176$, 177

Red Cross see American Red Cross; International Committee of the Red Cross

Red Sea 41, 45

"Red Sea waifs" (slave girls intercepted on the Red Sea) 45

Reds (Finnish left-wing fighters) $\quad 250$

Reeves-Ellington, Barbara 3

refugee camps

British/Anglican (Baquba) 110, 113, 114

Palestine 253

refugees

Arab 11-12, 248, 249

Armenian 6, 168, 187-188, 196-197, 203

Assyrian 110, 117

in Beirut $\quad 162$

in Istanbul $\quad 162$

Jewish 11-12, 236-237, 238, 249

medical assistance to 10

Polish 264, 264n25, 266, 268, 268n46

Russian 168

see also Palestinian refugees (Jerusalem)

relief work $8,12,68,95,225$

budget/expenditure 161

emergency relief $5,9,68,91,210, \mathbf{2 2 1 -}$ 224, 227

faith-based vs. modern 6

see also humanitarian actions/work

religion

older/outdated forms of religion/"fossil-

ized" Church 121, 123-124, 126

role in establishment of humanitarian-

ism/missions 10, 21

religious congregations, charitable activities

by 23 religious freedom $175,176,177,179$

religious law see Mosaic law; Shari'a

Renton, James 244

Reynods, Rev. G.C. $\quad 75,75 n 49$

RF see Rockefeller Foundation

rhetoric, of missionaries 8

Rioli, Maria Chiara $\quad 11,12$

rites and ceremonies, old/outdated preserved 121,123

Robert College (Istanbul) 156, 160, 166 see also Near East Colleges Association

Rockefeller Foundation (RF) 10

in China $157,163,171,176,177$

consideration of political circumstances/politicization $\quad 164-166,177$, 200

cooperation

with Near East Colleges (Association) 156-158, 161, 162, 163, 165, 166, 171176, 177-178, 179

with political authorities 165,178

focus on relief and social engineer-

ing/higher education $\quad 163,167-168$

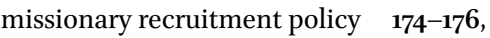
177

promotion of religious freedom 177 , 179

see also American University of Beirut

Rockefeller, John D. 162

Rock, Peter 263n23

Roman Catholic Church see Catholic

Church

Roman Catholic missions/missionaries see Catholic missions/missionaries

Rome $137,258,261$

Romema (neighbourhood, Jerusalem) $\quad 265$, 271-272tab.

Roosevelt, Franklin D. 198

Rouse, Ruth 118n22

Roussel, Louis (French abbot) 138

Royal Army Medical Corps 221

Royaume Arabe $\quad$ 133, 135, 138

rural development $161,164,178,213,224$, 225,242

Russe, Joseph le $\quad 265$

Russian (Orthodox) missions/missionaries

111

in Persia 111, 113

Russian refugees $\quad 168$ 
Russia/Soviet Union 197

Finland and $235,235 \mathrm{n} 4,238,238 \mathrm{n} 13$, 246, 248, 249 population transfers $25^{\circ}$

Jews in 235

Kurdistan and 110

Russo-Finnish War (Winter War, 1939-1940) 248

Saaïdia, O. 146

Saarisalo, Rev. Aapeli $\quad 235^{-236}$

Sabbah, Michel (Latin Patriarch of Jerusalem, 1987-2008) 26o

Sabogg, Hana 189

Safad (Palestine) 211, 219n44, 223 medical missions in 211, 216

Sahara 137

Sa'id of Egypt (Mohamed Sacid Pasha, Governor of Egypt, r. 1854-1863) 46-47

St Andrews Memorial Church (Jerusalem) 226

St Cyprien (model village, Algeria) $\quad 144,148$, 150

Saint-Joseph University (Jesuits, Beirut) Faculty of Medicine 33

funding of $28,3 \circ, 33-34,35$

St Mary's Home and School (Jerusalem) 239

Ste Monique (model village, Algeria) 144

St Saviour's Convent (Jerusalem) 262, 267 see also casa nova (Jerusalem)

Salem, Célestin (teacher) 149

Salesians of Don Bosco 24

Salisbury 114

Salla (Finland) 250

Salt (Jordan) 266

Salvatici, Silvia 3 nıo

Sand, Shlomo 242

sanitation

focus on $73,74,75,81$

see also "Christian" civilization

Sargon (Assyrian Mesopotamian king) 121, $121 n_{35}$

Scandinavia, women's mission's organizations 95

Scandinavian missions/missionaries 96 , 101

in Anatolia $\quad 84 n 73,90-91,92,94,98$, 105ill., 107ill. for Armenians $\quad 5,6,9,9 \circ, 92-93,95,97-$ 103

in Persia 111

see also Biørn, Bodil; Finnish missions/missionaries; KVA; Nordic missions/missionaries; Norwegian missions/missionaries; Swedish missions/missionaries

Schaefer, Lieutenant-Colonel (Director of Slave Department) $\quad 47-48$

School for Midwives (Egypt) 55, 56 schools (missionary)

in Aleppo 188, 215

American 188, 198-199

in Anatolia 99, 101-102

British/Anglican $50,113,114,212 n 15$, 213n24, 239, 242

in Cilicia 201

curricula $24-25,53,102,102 n 45,213-214$, 246

in Damascus 24-25, 194

Finnish 237, 238

for freed slaves/slave children (Cairo) 8 , $41,43,44-45,47,5^{\circ}, 5^{2-54}, 5^{8}$

French 143, 145

funding 28-29

tuition fees $24,27,28,30,161,167$

German 99, 101-102

girls schools 101, 102, 103, 104, 107ill., 193-194

government vs. missionary $102-103$, 214-215

home schools 237,238

in Jerusalem $\quad 215,239,240,241$

Jesuit $\quad 28-29,32,166$

language of instruction/language training 212, 238, 239, 245, 246

in Lebanon 187,215

in Palestine/Israel 211-215, 223, 239, 240, 241, 245, 250-251

Scottish Presbyterian 211-215, 223, 224, 225

students as best practices $\quad 76-77$

in Tripoli 193-194

Zionist 222

see also colleges (missionary); medical education/schools

Scotch Free Church mission 54

Scots College (Safad) 223, 224, 225 
Scottish Presbyterian missions/missionaries

after World War II $\quad 227$

competition with Zionists $\quad$ 221-223, 225, 226, 227

cooperation with British Mandate government $\quad 226$

educational projects/schools/colleges

211-215, 223, 224, 225

emergency relief work 210, 221-224, 227

funding of/fundraising $\quad 222-223,224$

hospitals 221

in Interwar period $\quad$ 209, 219-225

medical missions/projects $\quad 11,211,216-$ 219, 222

in Palestine 11, 209, 210, 211, 238

in Syria 210

Scott-Moncrieff, Colonel 49

Second Empire see Algeria

Second Vatican Council $\quad$ 257-258nı1

secularization of missionary activities/organizations $6,10,21-22,23,156-157,158,159$, 16o-161, 163-164, 167, 174-175, 177

Sedra, Paul 3

self-supportiveness of missionary organizations $159,167,172,173,178$

Semele massacre (1933) 117

Semple, Rev. Samuel Hanna 223

Senegal 141

The Separation of the Monophysites (William Ainger Wigram) 116

Service des Rapatriements et de l'Assistance 200

Shalhevetyah Christian School for Jewish

Children (Jerusalem) 241, 245, 250251

Shari’a (Islamic law) 141, 149

civil law vs. $\quad 141,149$

slavery and $\quad 46,47$

Sharkey, Heather $\quad 5^{1}$

Shedd, Mary Lewis $111 n$

sick people

charitable activities for 23

evangelization vs. caring $\quad 25$

Sidon (Lebanon) 190

silk mills/cultivation $\quad 25,26,28$

Sinai Peninsula 253

Six-Day War (Arab-Israeli War, 1967) 250, 253 slave girls $\quad 41$

average age of 43-44

naming of 46

origins of 44

price of 47

religious identity/conversion of 46

singing and dancing by 44

see also freed slave girls

slavery/slave trade $\quad 41-42,135$

abolitionists $\quad 46,47,48,51,183 \mathrm{nl}$

America $47,5^{1}$

Egypt $41-42,43,46,47,5^{8}$

end of $8,41,42-43,45,46-47,47$

Mecca 47

Shari'a and 46, 47

slave caravans $\quad 41,51$

smuggling of slaves $45,47-48,49-5^{\circ}$

Zanzibar 135

slaves

Abyssinian and Sudanese $\quad 47,48$

manumission papers $\quad 47,48$

memoirs of 41

relationship with slavers $\quad 41$

see also freed slave girls; freed slaves

Småberg, Maria 226, 242

Smith, Margaret 24

social change see "Christian" civilization

social and cultural conversion see "Christian" civilization

Societé des Missionaires d' Afrique (White Fathers, Charles Lavigerie) $\quad$ 134, 135, 137, 139, 148, 149

Society of Eastern Schools (CEvre des Écoles d'Orient) $30,31,32$

Society of the Immaculate Conception (Vienna) 32

Society of Jesus funding of missionary activities $\quad 27$ see also Jesuit missions/missionaries

Soros, George 155

Sœurs de Saint-Joseph de l'Apparition $\quad 25$

Souq Al-Gharb (Lebanon) 187

South Arabia 210

South Asia $\quad 158$

Southwest Africa $\quad 235$

Soviet Union see Russia/Soviet Union

SPC see Syrian Protestant College

Spellman, Francis (Archbishop of New York, 1939-1967) $\quad 261$ 
Spiritans 137

SPRF (Syrian and Palestine Relief Fund) 220, 221

Stamatov, Peter $183 \mathrm{n} 1$

Standard Oil 202

state schools, missionary schools vs. $\quad 102-$ 103, 214-215

state subsidies $\quad 169-171$

Staub, Albert $\quad 170-171$

Steele, Thomas (missionary) $219 n 44$

Stenius, Elna (independent missionary) 239-240

stereotyping of beneficiaries $\quad$ 191-192, 192193ill.

see also American Board of Commissioners for Foreign Missions; Orientalism

Stockdale, Nancy 212

Stoever, Edward R. $\quad 200$

student homes (Jerusalem) 11

Sub-Saharan Africa $\quad$ 133, 137

model villages 150

subsidies, state $\quad 169-171$

Sudan/Sudanese $\quad 25,27,43,44,46,133 n 2$ see also freed slave girls

Suomen Lähetyssanomia (magazine, FELM) 245,246

Surma (sister of Mar Shimun xıx Benyamin) 113

Susan (slave girl) $\quad 44,45,46,50,53$

Sweden 91

Finland and 248

Swedish Jerusalem Church $\quad 256$

Swedish Jerusalem Society 240

Swedish missions/missionaries (Palestine) 4n11, 6, 238, 240

Swedish School for Arab Children (Jerusalem) 240, 241

Swiss missions/missionaries 5

Syria $\quad 8,22,25,220,244$

American humanitarian activities in 10-11, 165, 184, 185, 186, 191, 197, 199, 200-203, 204

Assyrians in 113,126

famine $\quad 161$

Jesuit missions/missionaries in $\quad 27$ medical education in 163, 166 opposition against French Mandatory Power 165,169
Scottish Presbyterian missions/missionaries in 210

see also American University of Beirut

Syriac Orthodox Church $\quad 116$

Syriacs/Syriac Orthodox community 63, 112

Syrian Catholic community 112

Syrian Civil War (186o) 1, 8, 12, 23, 29

Syrian Orphanage (Jerusalem) 1

Syrian Protestant College (sPC, Beirut) 82 , 218

funding of $30,156,162$

student strike (1909) 175

see also American University of Beirut; Near East Colleges Association

Syrian Protestant Institute (Homs) 193

Syria and Palestine Relief Fund (SPRF) 220, 221

Tabeetha School (Jaffa) 211, 223, 224

Taithe, Bertrand 10

Talbieh (neighbourhood, Jerusalem) 266, $272 t a b$.

Tanta (Egypt) 55

tanzimat reforms (Ottoman Empire) 211212, 215

technocratization, of missionary/humanitarian organizations 184, 195

Testa, Gustavo (Patriarchal regent and Apostolic Delegate) $\quad 258$

Third Republic see Algeria

Thompson, Anna $\quad 44,52-53,54,57$

Thompson, Elizabeth 103

Tiberias (Palestine) 213n2o, 218, 219n44, 223,224

medical missions in $\quad 211,216$

missionary schools $\quad 211,215$

Tiquet, Père 148

Toledano, Ehud 41, 43

Torrance, Dr David 216, 217-218, 217n39-40, 225

transformation of converts locals/villagers $\quad 75^{-77}, 75^{-77}$ ill.

orphans $69,71,72$

see also "Christian" civilization; Orientalism

transnational cooperation/mission work 95-96, 99

Treaty of Amity and Commerce (Lausanne, 1923) 170-171 
tribes, conversion of 145

Trinity Hall (Cambridge) 114

Tripoli 190 schools 193-194 silk mill $\quad 25$

Trongue (slave girl) $\quad 48$

Tucker, Judith 42

tuition fees $24,27,28,30,161,167$

Tulkoon valtakuntasi (Christmas magazine, FELM) 241

Tunisia 135

Turin, Yvonne 146

Turkey, Ottoman 110, 120

Scandinavian missions/missionaries in see Anatolia

see also Ottoman Empire

Turkey, Republic of $\quad 177,184,198,220$

American missions/missionaries in 171 190

non-Muslims in 175

population transfers with Greece 250

reception of missionary work 155,165 , 171

Turkish language 102

Turks (Anatolia) 93, 99

Turku (Finland) $\quad 235 \mathrm{n} 4$

Tylor, Edward Burnett $\quad 119,121 n 34,122,123-$ 124

UNHCR (United Nations High Commissioner for Refugees) $\quad 227$

United Free Church of Scotland 11, 211, 220 , 222, 223, 225

see also Church of Scotland; Scottish Presbyterian missions/missionaries

United Nations $\quad 7,227,253$

United Nations High Commissioner for Refugees (UNHCR) 227

United Nations Partition Plan for Palestine (UN Resolution 181-II-) 253, 258

United Nations Relief and Works Agency for Palestine Refugees in the Near East (UNRWA) 7, 227, 253, 256 archives 257

United Presbyterian Church of North America (UPCNA) $5^{1}$

United States $\quad 116$

American foreign rule vs. British/French colonial rule 195 end of slavery $\quad 47$

French Mandate vs. 199, 200-203, 204

funding of missionary and humanitarian work $22,27,30,31,169,170-171$

migration to 114,126

political involvement in mandatory territories 10, 170-171, 197-199

universities

Jesuit $\quad 28-29$

see also American University of Beirut

University of Helsinki 235

UnRWA see United Nations Relief and Works Agency

unskilled workers 101

charitable activities for $23,25^{-26}$

UPCNA (United Presbyterian Church of

North America) $\quad 51$

Urfa (Anatolia) 200 orphanage 69,71

Urmia (region, Persia) 111-112, 113, 115

US Grain Corporation $\quad 189$

Valerga, Giuseppe $\quad 263$

Van (region, Anatolia) 75, 113, 114

Vatican 7

Vatican Apostolic Archives $\quad$ 13, 258, $25^{8 \mathrm{n} 13}$

Verdeil, Chantal 8

Vergani, Antonio (Patriarchal Vicar for Galilee) $\quad 256 \mathrm{n} 7$

Vester, Bertha Spafford $\quad 241$

Vickery, Charles 196

villagers

transformation of $\quad 75^{-77}, 75^{-77}$ ill.

see also "Christian" civilization

villages of colonization see model villages

Vincent, George E. 163, 166, 173

violent nationalism $\quad 242$

visual representation of missionary work see photographic representation/description

Vital, Dr (protégé of Lavigerie) 141-142

Wahba, Ali Pasha (slave trader) 50

Walker-Arnott, Jane 212

Walls, Andrew 216

waqf (Islamic charity) 183-184

war, mission work during times of $\quad 5,7$ 
Ward, Charlotte Allen $\quad 187$

Ward, Edwin St John $\quad 187$

War of Independence see Palestine War

Watenpaugh, Keith David $\quad 6,184,185,186$, 197-198

Wattignies (model village, Algeria) 147

Welsch, Herbert 187

Wesley, J. 910

West Bank 253

Western Turkey Mission (ABCFM) 62

White Fathers (Societé des Missionaires d'Afrique, Charles Lavigerie) $\quad$ 134, 135, 137, 139, 148, 149

wHo (World Health Organization) 227

Wigram, Edgar T.A. $\quad$ 115-116

Wigram, Rev. William Ainger 9, 110

ecumenical thinking of $115,116,117,125$ 126

on "fossilized" Church concept $\quad 121,123-$ 124,126

life 114

racial/ethno-religious thinking of $\quad 122-$ 123,125

wartime incarceration $\quad 114,116-117 n 15$

works 110, 114-117

see also [The] Cradle of Mankind

Williams, Peter 218

Wilson, Woodrow $\quad$ 170, 198

Winter War (Russo-Finnish War, 1939-1940) 248

Wise, Stephen 187

women

clothing and hair style $\quad 77-8$ o, 79ill., 1o6ill.

conversion of 79,92

education of 101, 220

equality of men and $93,103,220$

modernization of 220

spiritual equality of men and $\quad 92$

see also female missionaries

Women Mission Workers see KMA
Women's Jewish Mission Committee (Church of Scotland) 211, 223, 224

Women's Missionary Magazine $\quad 53,56$ women's mission organizations 91n4, 95, 19O, 211, 223, 224 see also KMA

workers, charitable activities for $\quad 23,25^{-26}$

World Health Organization (wHO) 227

World Missionary Conference (Edinburgh, 1910) 2, 209

World War I

transformation of missionary work during 5,6

see also Interwar period

World War II

development of global humanitarianism after $7,12,227$

see also Interwar period

Yale, William 202

Yemen 210

Yezidis 65,118

Yishuv (Jewish settlement, Palestine) 233

YMCA (Young Men's Christian Association) 189-190, 201

Yohannan, Abraham 113

Young Men's Christian Association (YMCA) 189-19o

Young Turk Revolution (1908) 102n45

Young Women's Christian Association (YWCA) 190

YWCA (Young Women's Christian Association) 190

Zahlé (Lebanon) 20, 200, 200n71

Zanzibar 135

Zionism/Zionists $\quad$ 221, 227, 242, 249 competition with missionaries $\mathbf{2 2 1 - 2 2 3}$, 225,226

schools and hospitals 222

Zionist-Arab war see Palestine War 